Portland State University

PDXScholar

\title{
Assessing the Effects of Climate Change and Fuel Treatments on Forest Dynamics and Wildfire in Dry Mixed-Conifer Forests of the Inland West: Linking Landscape and Social Perspectives
}

Brooke Alyce Cassell

Portland State University

Follow this and additional works at: https://pdxscholar.library.pdx.edu/open_access_etds

Part of the Environmental Sciences Commons, and the Forest Management Commons Let us know how access to this document benefits you.

\section{Recommended Citation}

Cassell, Brooke Alyce, "Assessing the Effects of Climate Change and Fuel Treatments on Forest Dynamics and Wildfire in Dry Mixed-Conifer Forests of the Inland West: Linking Landscape and Social Perspectives" (2018). Dissertations and Theses. Paper 4226.

https://doi.org/10.15760/etd.6110

This Dissertation is brought to you for free and open access. It has been accepted for inclusion in Dissertations and Theses by an authorized administrator of PDXScholar. Please contact us if we can make this document more accessible: pdxscholar@pdx.edu. 
Assessing the Effects of Climate Change and Fuel Treatments on Forest Dynamics and Wildfire in Dry Mixed-Conifer Forests of the Inland West:

Linking Landscape and Social Perspectives

by

Brooke Alyce Cassell

A dissertation submitted in partial fulfillment of the requirements for the degree of

Doctor of Philosophy

in

Earth, Environment and Society

Dissertation Committee:

Robert M. Scheller, Chair

Jeffrey Gerwing

Andrés Holz

Max Nielsen-Pincus

Vivek Shandas

Portland State University

2018 


\section{(C) 2018 Brooke Alyce Cassell}

This work is licensed under the Creative Commons Attribution-NonCommercial 4.0

International License. To view a copy of this license, visit

http://creativecommons.org/licenses/by-nc/4.0/. 


\begin{abstract}
Over the past century in the western United States, warming has produced larger and more severe wildfires than previously recorded. General circulation models and their ensembles project continued increases in temperature and the proportion of precipitation falling as rain. Warmer and wetter conditions may change forest successional trajectories by modifying rates of vegetation establishment, competition, growth, reproduction, and mortality. Many questions remain regarding how these changes will occur across landscapes and how disturbances, such as wildfire, may interact with changes to climate and vegetation. Forest management is used to proactively modify forest structure and composition to improve fire resilience. Yet, research is needed to assess how to best utilize mechanical fuel reduction and prescribed fire at the landscape scale. Human communities also exist within these landscapes, and decisions regarding how to manage forests must carefully consider how management will affect such communities.

In this work, I analyzed three aspects of forest management at large spatiotemporal scales: (1) climate effects on forest composition and wildfire activity; (2) efficacy of fuel management strategies toward reducing wildfire spread and severity; and, (3) local resident perspectives on forest management. Using a forest landscape model, simulations of forest dynamics were used to investigate relationships among climate, wildfire, and topography with long-term changes in biomass for a fire-prone dry-conifer landscape in eastern Oregon, United States. I compared the effectiveness of
\end{abstract}


fuel treatment strategies for reducing wildfire under both contemporary and extreme weather. Fuel treatment scenarios included "business as usual" and strategies that increased the area treated with harvest and prescribed fire, and all strategies were compared by distributing them across the landscape and by concentrating them in areas at the greatest risk for high-severity wildfire. To investigate local community preferences for forest management, I used focus groups, interviews, and questionnaires. Through open-ended questions and a public participation geographic information systems (PPGIS) mapping exercise, local residents expressed their views on fuels reduction treatments by commercial and non-commercial harvest and prescribed fire. Emergent themes were used to inform alternative management scenarios to explore the usefulness of using PPGIS to generate modeling inputs. Scenarios ranged from restoration-only treatments to short-rotation commercial harvest.

Under climate change, wildfire was more frequent, more expansive, and more severe, and ponderosa pine expanded its range into existing shrublands and highelevation zones. There was a near-complete loss of native high-elevation tree species, such as Engelmann spruce and whitebark pine. Loss of these species were most strongly linked to burn frequency; this effect was greatest at high elevations and on steep slopes.

Fuel reduction was effective at reducing wildfire spread and severity compared to unmanaged landscapes. Spatially optimizing mechanical removal of trees in areas at risk for high-severity wildfire was equally effective as distributing tree removal across the landscape. Tripling the annual area of prescribed burns was needed to affect 
landscape-level wildfire spread and severity, and distributing prescribed burns across the study area was more effective than concentrating fires in high-risk areas.

Focus group participants generally approved of all types of forest management and agreed that all areas should be managed with the "appropriate" type of treatment for each forest stand, and that decisions about management should be made by "experts." However, there was disagreement related to who the "experts" are and how much public input should be included in the decision making process. Degree of trust in land management agencies contributed to polarized views about who the primary decision makers and what the focus of management should be. While most participants agreed that prescribed fire was a useful tool for preventing wildfire spread and severity, many expressed reservations about its use.

I conclude that forest management can be used to reduce wildfire activity in drymixed conifer forests and that spatially optimizing mechanical treatments in high-risk areas can be a useful tool for reducing the cost and ecological impact associated with harvest operations. While reducing the severity and spread of wildfire may slow some long-term species shifts, high sub-alpine tree mortality occurred under all climate and fuel treatment scenarios. Thus, while forest management may prolong the existence of sub-alpine forests, shifts in temperature, precipitation, and wildfire may overtake management within this century. The use of PPGIS was useful for delineating the range of forest management preferences within the local community, for identifying areas of agreement among residents who have otherwise polarized views, and for generating 
modeling inputs that reflect views that may not be obtained through extant official channels for public participation. Because the local community has concerns about the use of prescribed fire, more education and outreach is needed. This may increase public acceptance of the amounts of prescribed fire needed to modify wildfire trajectories under future climate conditions. 


\section{Dedication}

This dissertation is dedicated to Jesse, who has been alongside me through all the twists and turns of graduate school. 


\section{Acknowledgments}

There are many people who have contributed to this research, from the nittygritty details to lending an ear when I needed to talk through the overarching questions. First, thank you to the fuels managers, silviculturists, ecologists, and soil scientists who shared data and spent time building scenarios with me. From the U.S. Forest Service: Amy Unthank, Larry Amell, Karen Bennett, Steve Campbell, Michael Jennings, Dana Skelly, Nathan Poage, Roy Walker, Tim Boyce, Ed Clark, Lori Stokes, Amanda Lindsay, Gunnar Carnwath, Sabine Mellmann-Brown, Jason McGovern, Brie Myers, Chris Parker, Dave Halemeier, Greg Moon, Joseph Rausch, and Donald Hann. From Oregon Department of Forestry: Kirk Osland. From the Bureau of Land Management: Tim Newkirk and Steve Castillo. And from Oregon State University: Chris Ringo.

Special thanks to the Blue Mountain Forest Partners, the Harney County Restoration Collaborative, and the High Desert Partnership for welcoming me and sharing information about collaborative forestry on the Malheur National Forest. I am indebted to Mark Webb, Jack Southworth, Susan Jane Brown, Pam Hardy, Trent Seager, and Brenda Smith. James Johnston, thank you for freely sharing your tree and fire data for the Malheur. I'd also like to thank Kerry Kemp from The Nature Conservancy for your help brainstorming ways to successfully carry out my focus groups.

I would also like to thank my labmates and fellow graduate students, especially Kyla Zaret, Erin Rivers, Cody Evers, Charles Maxwell, Hari Luintel, Tina Mozelewski, Sara Loreno, Bruce Marron, Megan Creutzburg, Wes Hoyer, Trevor Gareth Jones, and 
Zachary Robbins, who have helped me talk through, work through, and happy-hour through countless sticky research issues. Special thanks to Alec Kretchen for sharing your R and LANDIS-II expertise and to Garry Sotnik for your tireless support and encouragement. I would also like to express my thanks to Daveena Tauber for your encouragement and excellent dissertation-writing advice. Marley Luke and Kristen Purdy, I could not have completed the third chapter of my dissertation without your resourceful assistance in the field and your tireless transcribing of audio.

To Melissa Lucash, I have no words to express the deep appreciation I have for your generosity. From R codes and LANDIS-II advice to afternoon walks, career insights, and friendship, you are my mentor and my research hero. And thank you to Anna and Celia for keeping me supplied in lizards, dragons, and hugs.

Considerable thanks to E. Louise Loudermilk for your support and for authoring the grant that brought me to Portland State University. Your generosity has facilitated my doctoral education, and I am forever grateful. Thanks also to Matthew Hurteau and Dan Krofcheck for collaboration on this project and to Pep Serra Diaz and Matthew Duvenick for your technical expertise.

To my family, who have waited patiently for me to start traveling to family gettogethers and who have been a source of so much emotional support and encouragement through these years of graduate school, thank you, thank you, thank you. To Jesse, who has been there through all the day-to-day challenges and triumphs, cheering me on at every step of the way. To my Mom, thank you for always believing in 
me, giving me unconditional support and understanding, and being a rock when I need you. To my Dad, thank you for never missing a thing, from choir concerts and theater performances to being here for the defense. It means the world to me. And to my best friend, Brooke Macnamara, you are a constant source of inspiration and motivation. I am so lucky to know you and to have your footsteps to follow.

Finally, I would like to thank my committee, Max Nielsen-Pincus, Andrés Holz, Jeffrey Gerwing, and Vivek Shandas, for helping me shape this research into a cohesive project and for helping me think about alternate ways to approach problem solving and research questions. And most of all, I am so grateful to my adviser, Robert Scheller, for these years of support, guidance, mentorship, and for believing in my potential. Thank you so very much.

Research funding for this project was provided by the Joint Fire Science Project under Project \#14-1-01-2 “Outcomes Prioritization on Fuel Treatment Placement in Extreme Fire Weather in three CFLRP Landscapes." Additional funds were provided by Microsoft Azure for Research, the Ed and Olive Bushby Scholarship Fund and the ABC Human Wildlife Control and Prevention, Inc's Women in STEM Scholarship Fund. 


\section{Table of Contents}

Abstract

Chapter 2 - More widespread and severe wildfires under climate change lead to

dramatic declines in high-elevation species in the dry mixed conifer forests of the

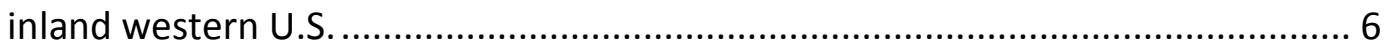

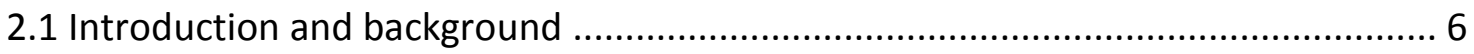

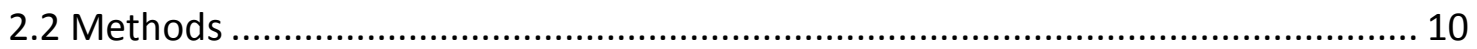

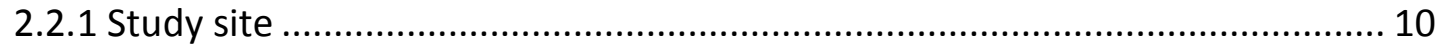

2.2.2 Overview of simulation model ................................................................ 14

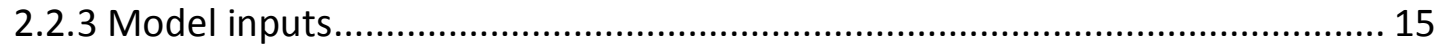

2.2.4 Model parameterization and validation.................................................... 22

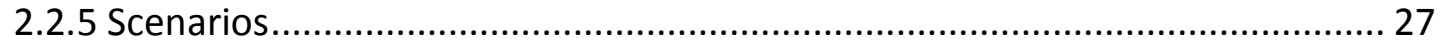

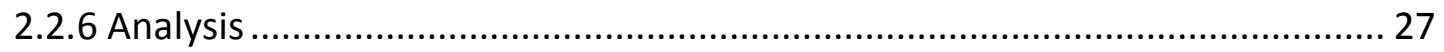

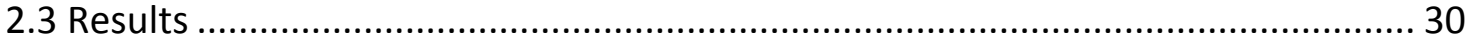

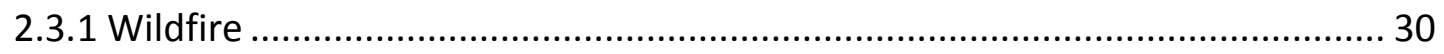

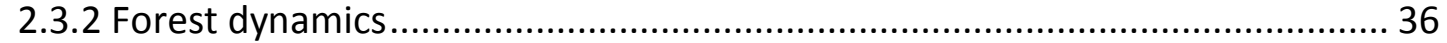

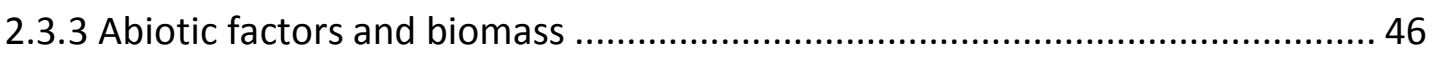

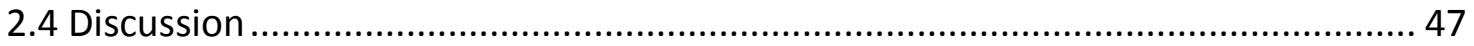

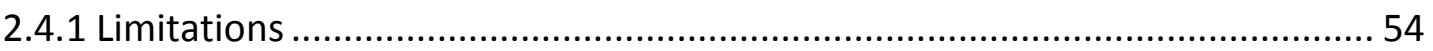

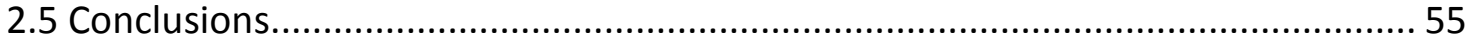


Chapter 3 - Optimizing placement of fuel treatments and accelerating prescribed fire ameliorates extreme weather-driven wildfires in western mixed-conifer forests

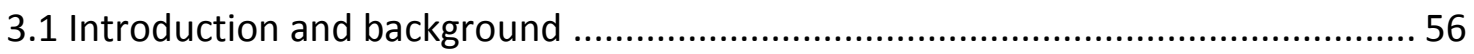

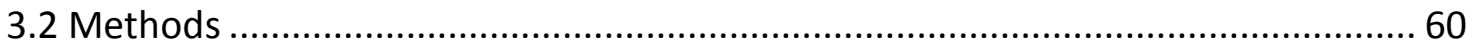

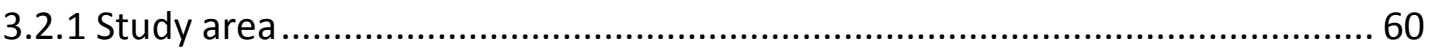

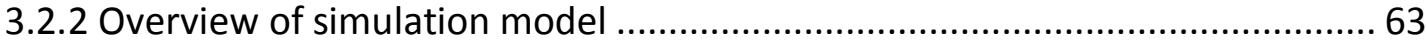

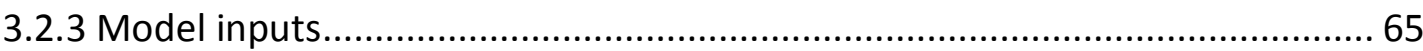

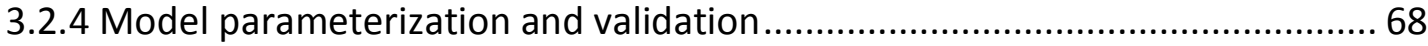

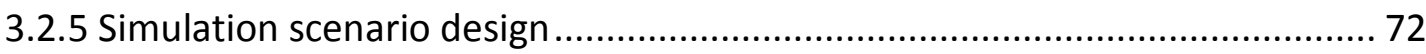

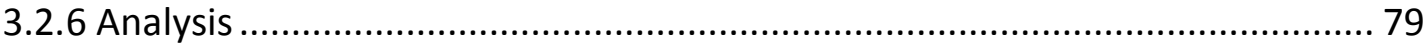

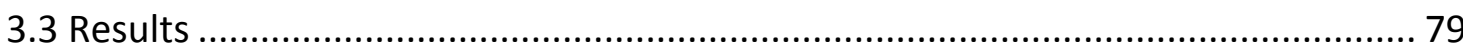

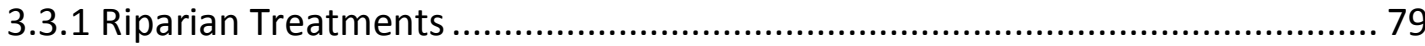

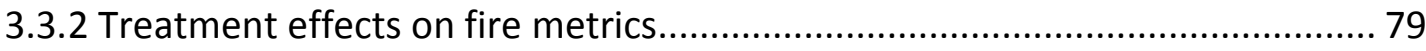

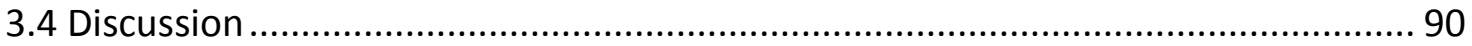

3.4.1 Effects of fuel treatments in riparian areas................................................ 93

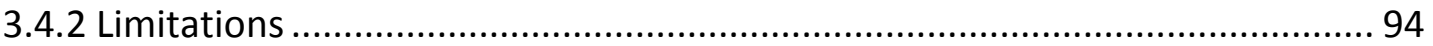

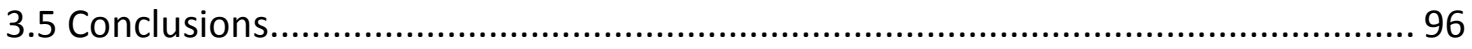

Chapter 4 - Local resident perspectives on forest management and implications for fuel treatments in a rural community in eastern Oregon ...................................... 98

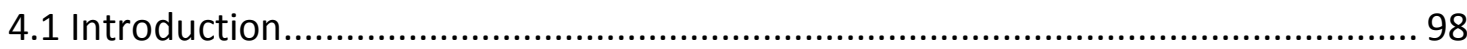

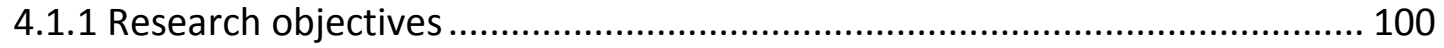

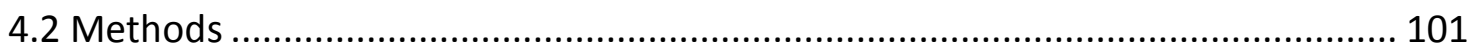

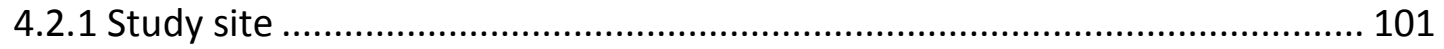

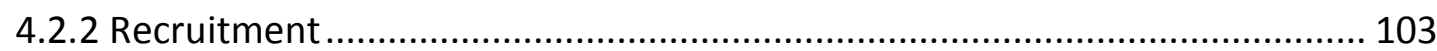

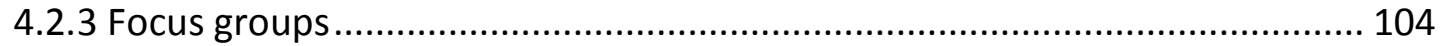

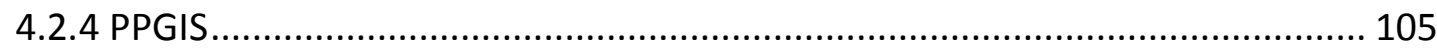

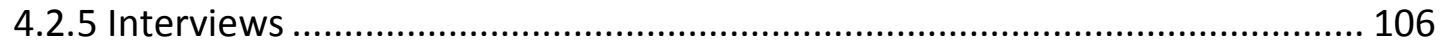


4.2.6 Scenario development and landscape simulations .................................. 107

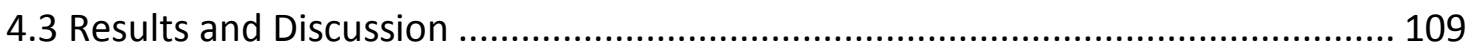

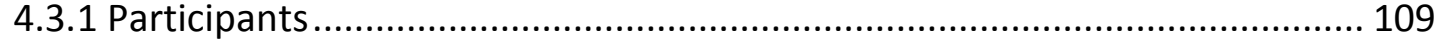

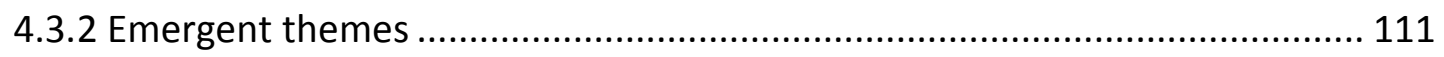

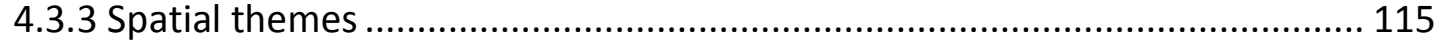

4.3.4 Management scenario development ................................................... 118

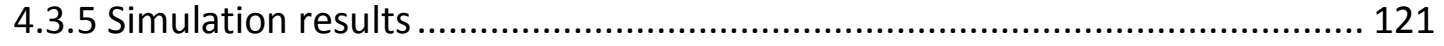

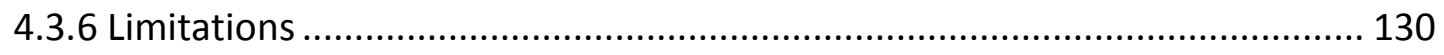

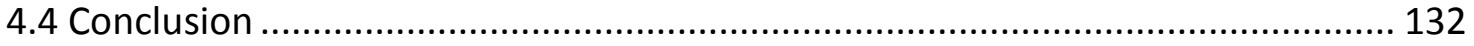

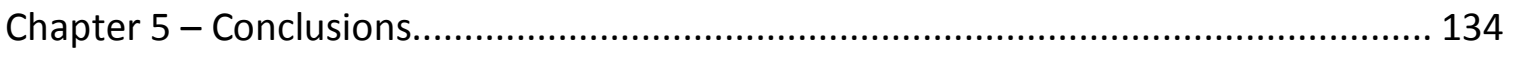

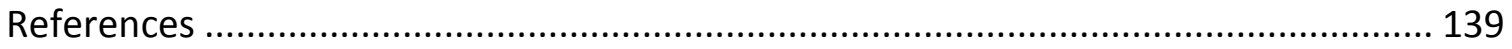

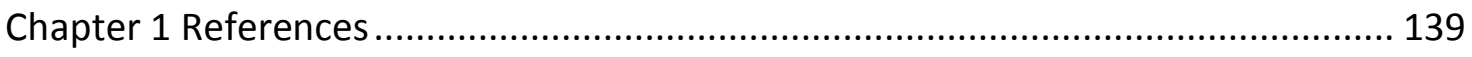

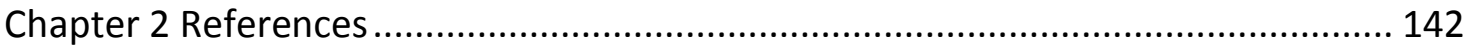

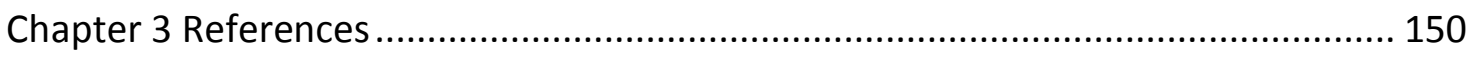

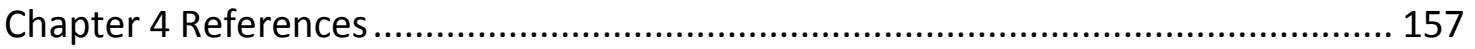

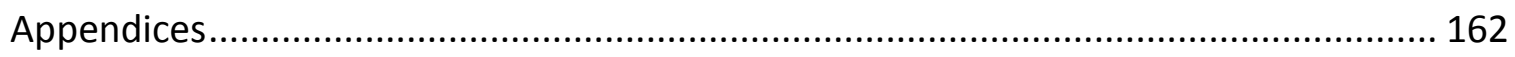

Appendix A. Supplemental material .................................................................. 162

Appendix B. Institutional Review Board Approval ............................................. 163

Appendix C. Focus group and participatory mapping materials ............................. 164

C.1 Informed consent cover letter for anonymous questionnaire ........................ 164

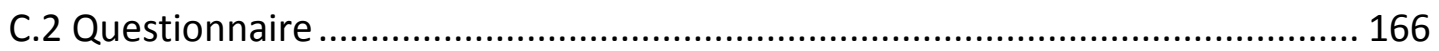

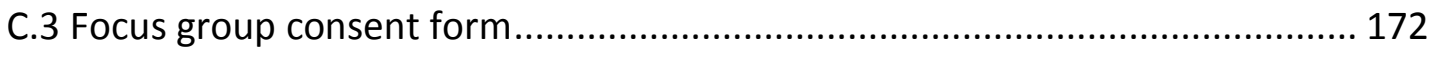

C. 4 Introductory presentation to focus group participants ................................ 175

C.5 Maps used in participatory mapping exercise ............................................. 179

C.6 Colors used in preference mapping …................................................... 183 


\section{List of Tables}

Table 2.1. Species life history trait input parameters.............................................. 21

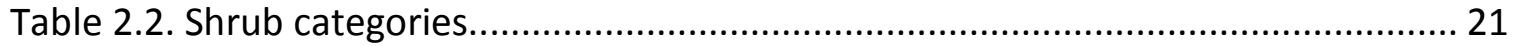

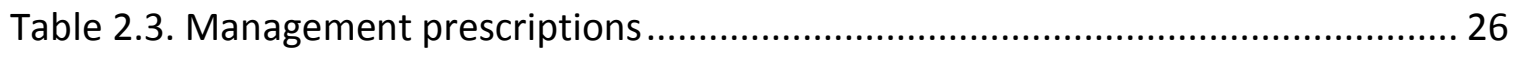

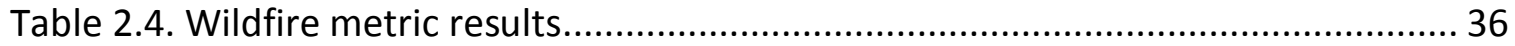

Table 2.5. Biomass density and extent values for all conifer tree species ..................... 41

Table 2.6. Results from permutational multivariate analysis of variance (PERMANOVA) 46

Table 3.1. Management scenarios and area treated................................................... 78

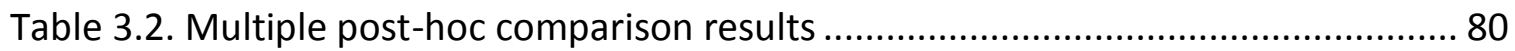

Table 3.3. Comparison of management scenarios' effects on wildfire annual area burned and severity for 1 . contemporary and extreme weather and 2. distributed and optimized treatment placement.................................................................... 89

Table 4.1. Emergent themes from focus group discussions, interviews and questionnaires

Table 4.2. Harvest scenario descriptions ............................................................. 120

Table 4.3. Wildfire metrics for the last 30 years of simulations (2071-2100).............. 125 


\section{List of Figures}

Figure 2.1. The study site, indicated by a thick black line, ........................................ 10

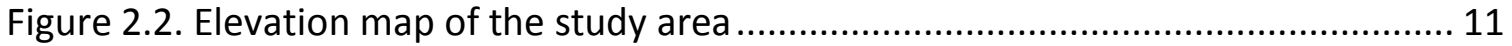

Figure 2.3. Ecoregions and climate gradients ...................................................... 12

Figure 2.4. Conceptual model and dynamic modeling design..................................... 16

Figure 2.5. General circulation models (GCMs) were selected ................................... 18

Figure 2.6. Range of maximum annual temperatures for all RCP 4.5 (orange) and RCP 8.5 (red) general circulation models used in simulations....................................... 18

Figure 2.7. Range of annual precipitation for all RCP 4.5 (turquoise) and RCP 8.5 (tan) general circulation models used in simulations ............................................ 19

Figure 2.8. Initial biomass $\left(\mathrm{g} \mathrm{m}^{-2}\right)$ at time zero as a measure of model validity .............. 23

Figure 2.9. Fire calibration was achieved through modeling the distribution of durations

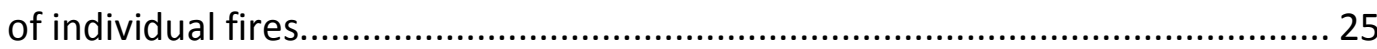

Figure 2.10. Correlation matrix of independent variables used in multivariate analysis of

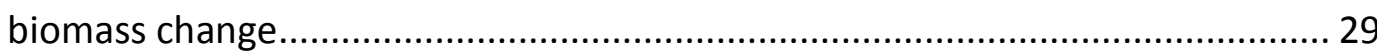

Figure 2.11. Shepard plot, which shows the non-metric and linear fit of observed dissimilarity and ordination distance for non-metric multi-dimensional scaling. 30

Figure 2.12. Annual area burned over time fitted with a locally weighted scatterplot

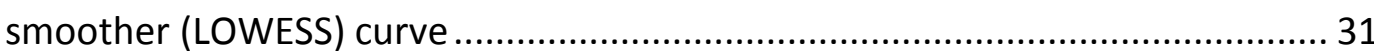

Figure 2.13. Annual area burned for the last 30 years of simulations under contemporary weather and climate change scenarios 33

Figure 2.14. Maps of probability that each individual site will burn during any given year under contemporary weather and climate change projections.......................... 33

Figure 2.15. Mean fire severity under contemporary weather and climate change projections averaged across 10 replicates for each scenario

Figure 2.16. Maps of mean fire severity averaged across all replicates and all years for each climate scenario 
Figure 2.17. Average total biomass and biomass of individual species through time for

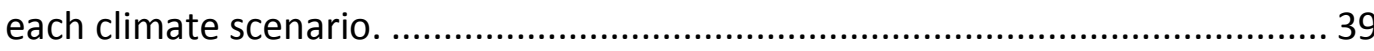

Figure 2.18. Average percent change in biomass density. .............................................. 40

Figure 2.19. Probability of establishment of conifer species under each climate scenario.

Figure 2.20. Non-metric multi-dimensional scaling (NMDS) ordination of change in biomass for the nine conifer species by weighted species scores .......................... 50

Figure 2.21. Non-metric multi-dimensional scaling (NMDS) ordination of change in biomass of six tree species across the elevational gradient................................. 51

Figure 3.1. The LANDIS-II forest landscape model (FLM) integrates forest successional dynamics with management and disturbance events across space and time ..... 65

Figure 3.2. Matrix of weather, harvest, and spatial placement scenarios ....................... 74

Figure 3.3. Distributed (a.) and spatially optimized (b.) management areas ................... 75

Figure 3.4. Boxplots of annual area burned under contemporary (a.) and extreme (b.) weather for each management scenario.............................................................. 82

Figure 3.5. Maps of total fire occurrence at each site over all replicates and years........ 84

Figure 3.6. Mean fire severity under extreme weather compared between distributed and spatially optimized treatments for the BAU and RxFire3x scenarios .............8 86

Figure 3.7. Boxplots of fire severity in forested portions of the landscape under contemporary (a.) and extreme (b.) weather for each management scenario ... 87

Figure 3.8. Density plots of mean fire severity under historical and extreme weather ... 89

Figure 4.1. Participants' questionnaire responses to the question, "What activities do you enjoy in the Malheur National Forest and the surrounding forested areas?"

Figure 4.2. Participatory mapping examples 118

Figure 4.3. Average annual biomass harvested over time for each of the fuel treatment/harvest scenarios

Figure 4.4. Annual area burned under each treatment/harvest scenario 123 xiv 
Figure 4.5. Mean fire severity for the final 30 years of landscape simulations (2070 -

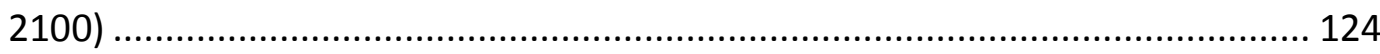

Figure 4.6. Maps of forest type and high-elevation forest loss over time .................... 128

Figure 4.7. High-elevation forest declines under all management scenarios ............... 128 


\section{Preface}

Chapters 2, 3, and 4 will be submitted to scientific journals as individual

manuscripts for publication. This is reflected through some repetition of background information and methods. References are cited at the end of the dissertation by chapter. 


\section{Chapter 1 - Introduction}

Wildfire management is an issue of increasing concern to communities in geographic locations where homes and natural resources are interspersed with fireprone forests (Brenkert-Smith et al. 2006, Gordon et al. 2010). Over a century of fire suppression, timber harvesting, grazing, and other land uses in the western United States have contributed to shifts in forest structure and composition, which have contributed to changes in fire frequency, size and severity (Heyerdahl et al. 2002, Franklin and Johnson 2012, Churchill et al. 2013, Halofsky et al. 2014, Hagmann et al. 2014). Annual area burned and the resulting economic impacts of increased fire suppression efforts and losses in natural resources and private property have increased over the past several decades and are expected to continue increasing (Littell et al. 2009). It is imperative to understand how forest composition will change under projected climate conditions and how fire occurrence, area burned, and severity will interact with changing forests and emissions-driven climate futures to inform effective forest management (Keane et al. 2009).

Previous studies have shown that fuel treatments in dry mixed-conifer forests are effective in reducing wildfire severity when fires intersect existing treatments (Prichard et al. 2010, Johnson et al. 2011, Syphard et al. 2011a, Safford et al. 2012) and that combining mechanical thinning with prescribed burning can be more effective than each treatment type alone (Schwilk et al. 2009). Modeling studies have also shown that managing forests to reduce fuel loading leads to improved resilience to wildfire (Fulé et 
al. 2001, Ager et al. 2010, Johnson et al. 2011, Halofsky et al. 2014, Loudermilk et al. 2014). However, wildfire activity is expected to increase with ongoing climate change (Westerling et al. 2006a, Fried et al. 2008, Littell et al. 2009, Abatzoglou and Williams 2016), and there is a need for greater understanding of how effective fuel treatments will be under future climatic conditions at the landscape scale and over time.

In addition, decisions about forest management must balance social needs with ecological needs and are constrained by economics, policy, and social acceptability (Brunson 1993, Bengston 1994, Shindler et al. 2002, Armitage et al. 2009). In regions where wildfire has increasingly affected communities through destruction of property, and losses of natural resources, communities have developed polarized views about how fire and forests should be managed (Gordon et al. 2010). Over the past two decades, social science research into the human dimensions of wildfire has increased, building a picture of the impacts of wildfire on humans and their views on wildfire prevention, suppression, and recovery (McCaffrey et al. 2013) even as an increasing number of people move into fire-prone landscapes (Theobald 2001, Radeloff et al. 2005). While decision-making around forest management practices in public forests rests with land management agencies, public input and collaboration are important steps in developing priorities and strategies.

The public has opportunities to review proposed plans and to provide input through public engagement meetings, participation in formal collaborative forestry organizations, or public comment on environmental impact statements (U.S. EPA 2017). 
But communities with low civic capacity resulting from issues such as a lack of trust in government decision-makers or long-term economic dissatisfaction may choose not to participate constructively in the collaborative process (Dent 2008). In fact, participation can increase civic capacity (Potapchuk and Crocker Jr 1999), creating a positive feedback that helps communities grow together instead of apart in terms of natural resource problem solving, further underscoring the benefits of community participation when opportunities exist. Therefore, this study links research into climate, forest management and wildfire with qualitative research into community preferences for fuel treatments in a rural landscape in eastern Oregon that is characterized by dry mixed-conifer forests and frequent wildfire (Johnston et al. 2017).

In Chapter 2, I examined the interactions among climate change, forest dynamics, and wildfire across the study landscape over a 90-year period. I used a dynamic forest landscape model to simulate forest growth and wildfire under three different climate scenarios: contemporary weather, moderate climate change (RCP 4.5) and high climate change (RCP 8.5). I met with fuels managers, ecologists and silviculturists to develop management prescriptions that reflect current practices for commercial harvest, non-commercial harvest, and prescribed fire. I held management constant across all three scenarios in order to quantify the degree to which the range of projected future climate conditions increase wildfire behavior and drive shifts in individual species biomass and extent on the landscape. Finally, I investigated shifts in biomass of individual tree species and used multi-variate analysis to understand how 
climate, wildfire, and abiotic landscape characteristics influenced changes in species dominance and persistence.

In Chapter 3, I took a comparative approach to assessing the effectiveness of alternate management strategies in reducing wildfire extent, frequency and severity. Leveraging the model parameters and calibration from Chapter 2, I developed management strategies that accelerated the pace of fuel treatments by adding management in riparian areas, where very little treatment currently occurs, and by doubling and tripling the annual area treated with prescribed fire. I then compared these treatment strategies under contemporary weather and under extreme weather conditions that occurred during years with high wildfire occurrence, spread, and severity. These conditions reflect the warmer temperatures, altered precipitation, and stronger winds that are expected to occur more frequently as the climate continues to warm (Westerling et al. 2006a), underscoring the importance of understanding how fuel treatment strategies will perform under these conditions.

To examine strategies that consider budgetary and social acceptability constraints to management, I assessed the potential for concentrating management activity into a smaller geographic area. Limiting the location of treatments could reduce costs associated with maintaining extensive road networks as well as meet a social objective of maintaining more area of forest that appears to be untouched or unmanaged. I ran 1,000 simulation-years of wildfire under extreme weather with no management to identify sites on the landscape that burned the most frequently at high 
severity and restricted management to those areas that were outside of protected areas (e.g. wilderness).

Finally, in Chapter 4, I delved further into issues of social acceptability and public input into forest management decision making using qualitative research on community preferences for fuel treatments. Through coding transcripts from focus groups and interviews, I identified seven primary themes and 35 sub-themes that inform community-members' preferences for fuel treatment. I developed spatial themes through a public participation geographic information systems (PPGIS) activity, which allowed participants to draw polygons on maps of the landscape to indicate where on the landscape they were willing to see different types of treatment including light/precommercial thinning, heavy thinning/commercial harvest, and prescribed fire. I used these preference and spatial themes to develop management strategies that reflect the range of participant preferences and compared their effectiveness in reducing wildfire activity and preserving sensitive forest under climate change over a 90-year simulation period.

This study used a landscape-level approach to link climate change with future wildfire and forest dynamics in dry ponderosa pine-dominated forests in eastern Oregon. It looked at long-term trajectories of wildfire activity during years with extreme weather under a range of management strategies. And it incorporated community input into the development of management strategies that aim to improve social acceptability of fuel treatments while examining tradeoffs between conflicting priorities. 


\section{Chapter 2 - More widespread and severe wildfires under climate change lead to dramatic declines in high-elevation species in the dry mixed conifer forests of the inland western U.S.}

\subsection{Introduction and background}

The climate in the western United States is rapidly changing (Pachauri et al. 2014), and area burned by wildfire has increased over the past several decades coincident with rising temperatures (Westerling et al. 2006, Abatzoglou and Williams 2016). This pattern is expected to continue because of longer fire-seasons, increased drought periods, and higher average temperatures. Hot and dry periods lead to greater ignition and fire spread probability through increasing live and dead fuel loading (Littell et al. 2016) especially, in some regions, when following wetter years that encourage additional vegetative growth and increase the continuity of fuels (Westerling et al. 2006). Dry forests in the western U.S. have experienced shifts in species composition and forest density over the past century (Franklin and Dyrness 1973, Agee 1998, Heyerdahl et al. 2001, Hessburg et al. 2005, Franklin and Johnson 2012, Hagmann et al. 2014). Many studies have documented these shifts, and although there is some disagreement about historical forest structure (Williams and Baker 2012, 2014, Fulé et al. 2014, Odion et al. 2014), most agree that vast areas of the west were covered by fire-adapted dry forests with low-severity, frequent ( $<35$ year return intervals) fire regimes (Franklin and Johnson 2012), and that anthropogenic influences have led to dry forests becoming denser with increased fuels (defined here as increased continuity of horizontal and 
vertical fuel structure), lower mean tree diameters, and a greater proportion of fire intolerant tree species such as Abies grandis (Larson and Churchill 2012).

Land-use and other anthropogenic factors have contributed to creating forests that no longer resemble those that existed before the early 1900s (Langston 1995, Hessburg et al. 2005, Stephens et al. 2009, Johnson et al. 2011). Fire suppression, forest and meadow conversion for cattle grazing and agriculture, and a history of extensive commercial timber harvest have driven a shift from large, widely-spaced trees to dense stands of small-diameter trees (Franklin and Johnson 2012, Churchill et al. 2013). This change in forest structure has also led to an increase in both horizontal and vertical fuel beds that support higher severity fires (Agee 1998, Agee and Skinner 2005).

Climate is interrelated with forest dynamics and wildfire in complex ways (Heyerdahl and Alvarado 2003, Whitlock 2003, Schoennagel et al. 2004, Brown et al. 2008) and drives vegetation distribution through the number of growing degree days, temperature, amount and timing of precipitation, and number of drought days. Species respond to these variables through growth, regeneration, competition, and mortality (Halofsky et al. 2013), and climate change-related reductions in snowpack, earlier spring snowmelt, and more frequent drought conditions contribute to weakened trees that are susceptible to disease and insect infestations. Changes in forest species composition (i.e., from fire-tolerant to intolerant species) exacerbates forests' susceptibility to fire, further shifting fire regimes from historically low-intensity, low-severity ground fires 
with patches of moderate and high severity to more extensive high-intensity, highseverity crown fires (Parsons and DeBenedetti 1979, Hessburg et al. 2005).

It is imperative that we understand how forest composition will change under projected climate conditions and how fire occurrence, area burned, and severity will interact with changing forests and emissions-driven climate futures to inform effective forest management (Keane et al. 2009). Restoring dry forests to more closely resemble historical forests in terms of composition, structure, and fire regime has been a focus of land management agencies for several decades (Agee and Skinner 2005). Guidelines for dry forest restoration are designed to improve resilience to disturbance, including wildfire, by managing for older/larger trees, reducing stand densities, favoring tree species that are fire- and drought-tolerant and creating a patchy mosaic of forest stands across the landscape (Agee and Skinner 2005, Franklin and Johnson 2012, Churchill et al. 2013). Considering likely shifts in species distribution and dominance across forests due to both climate change and changing fire regimes should be a key consideration when planning forest management activities.

Many studies link historical climate patterns with forest and fire dynamics to make predictions of future trends (Swetnam and Betancourt 1990, Swetnam 1993, Heyerdahl et al. 2002, Westerling et al. 2006, Brown et al. 2008) and to understand how forests will change over time under a range of projected climate conditions. Mechanistic models are frequently deployed to simulate known biophysical processes and their relationships with climate and to allow for comparisons among multiple management 
actions over long periods of time. These models can exceed the forecasting capacity of empirical studies and statistical models by simulating complex interactions among multiple ecological processes (e.g., plant establishment, competition and mortality, seed dispersal, climate variation and changes over time, and disturbances), allowing for spatial variation in conditions, changing conditions through time, and allowing for emergent behavior, e.g. novel conditions (Williams and Jackson 2007, Gustafson 2013). Carefully calibrated forest landscape models (FLMs) allow forest conditions and disturbance regimes to emerge through simulation and are not constrained by predefined states, which facilitates understanding not only beginning and ending points, but continuous trajectories of forest conditions through time (Gustafson 2013).

Through this study, I sought to understand the relationships among climate change, dry mixed-conifer forest dynamics and wildfire by comparing shifts in both forest composition and wildfire activity under contemporaryclimate and a range of projected climate conditions. To assess these relationships, I simulated forest and fire dynamics under current management practices in a fire-prone landscape in the Southern Blue Mountains of central Oregon under contemporaryweather and climate change conditions and compared fire activity and species distribution. I also sought to assess the relative contributions of increased fire activity, climate inputs, and other abiotic variables in driving species distribution across the landscape. 


\subsection{Methods}

\subsubsection{Study site}

The study site is located in the southern part of the Blue Mountains in central Oregon, U.S.A. (Figure 1), covering 938,786 ha, of which 666,330 ha are forested, 34,232 ha are potential forest (e.g., recently burned), and 238,224 ha are grasslands and shrublands (LEMMA, 2014). Elevation ranges from $719-2,744$ meters above sea level (Figure 2). Climate in the Blue Mountains is continental with cold, wet winters and hot, dry summers.

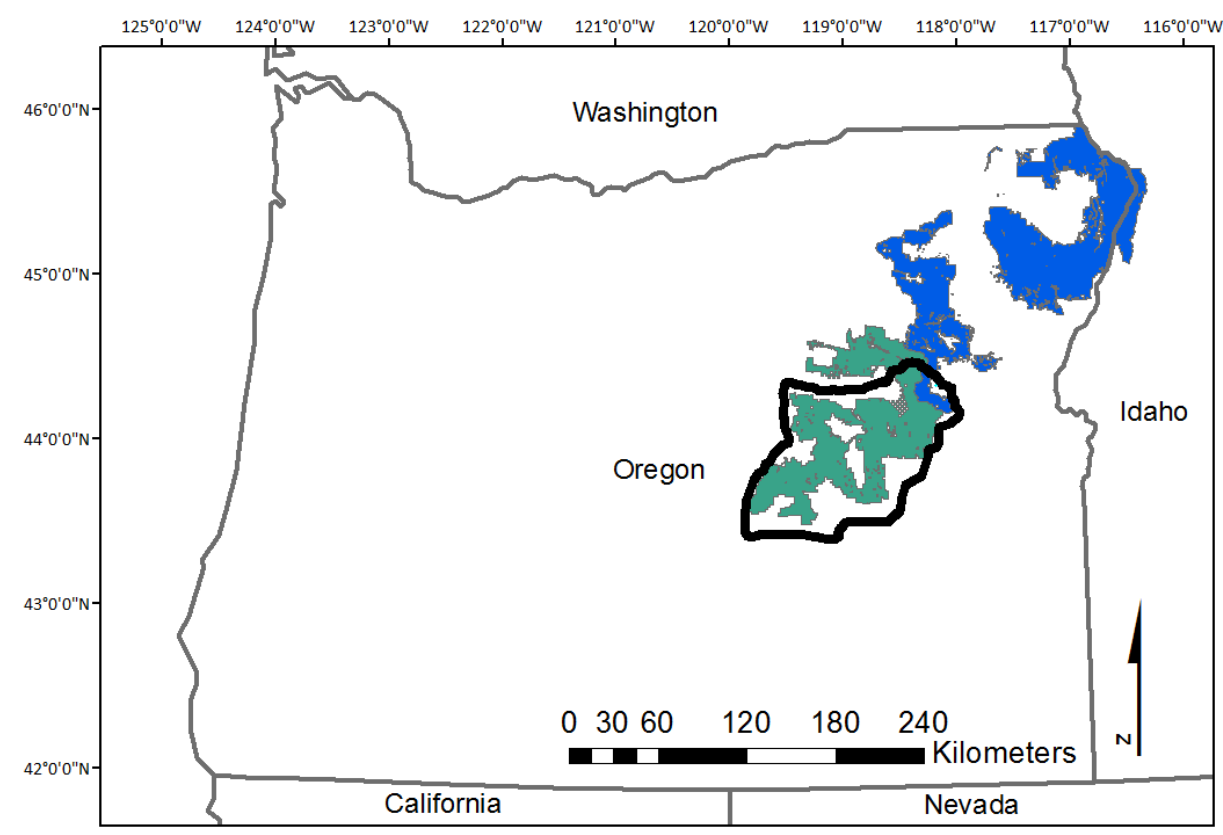

Figure 2.1. The study site, indicated by a thick black line, is located in the region of the Malheur (green) and Wallowa-Whitman (blue) National Forests in the southern Blue Mountains in Oregon, USA. 


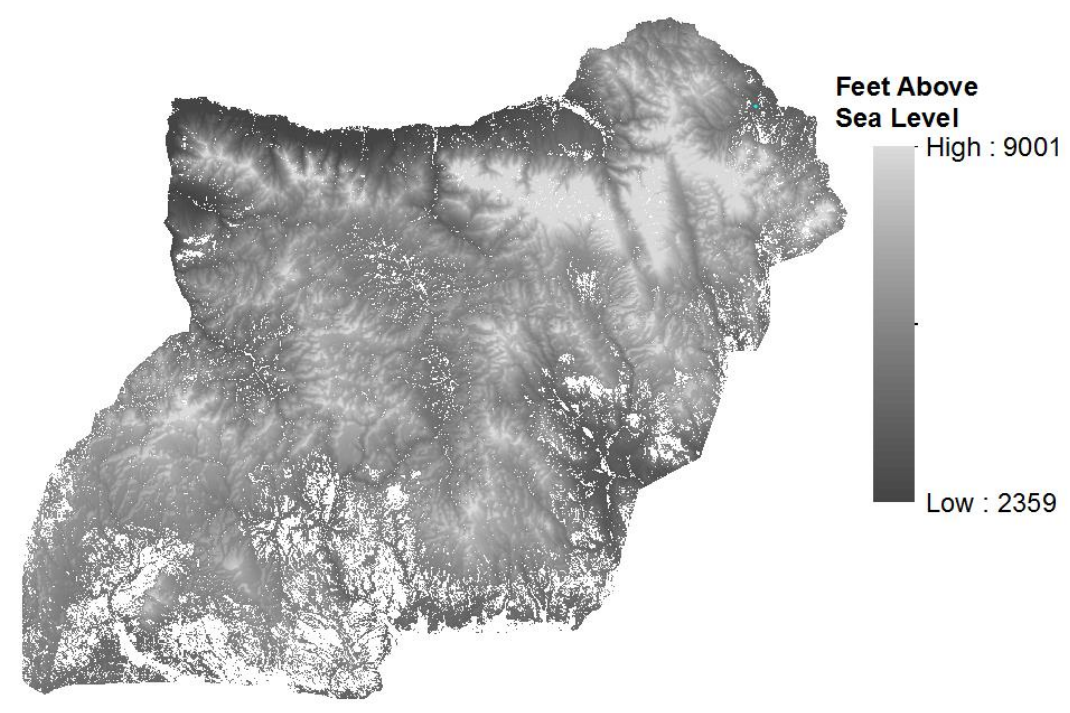

Figure 2.2. Elevation map of the study area. Elevation ranges from 2,359-9,001 feet (7192,744 meters) above sea level.

Mean January and June temperatures are $-3^{\circ} \mathrm{C}$ and $19.3^{\circ} \mathrm{C}$ respectively (1981 2010; NOAA 2016, average of 9 weather stations within the study area) with average annual precipitation of $364 \mathrm{~mm}$ (1979 - 2014; Abatzoglou 2013), most of which falls as snow (Heyerdahl et al. 2002, NOAA 2016). There is an increase in average summer precipitation (47 - $55 \mathrm{~mm}$ ) and a corresponding decrease in average summer temperatures $\left(27-25^{\circ} \mathrm{C}\right)$ from the southwest to the northeast of the study area (Figure 2.3). Climate fluctuations are influenced by the El Niño-Southern Oscillation (ENSO) phenomenon, which is linked to cyclic rising and falling of sea-surface temperatures in the equatorial Pacific Ocean (NOAA 2005). In the Pacific Northwest region, El Niño years are characterized by hot and dry winters and springs (Cayan et al. 1999, Heyerdahl et al. 2002), which in the Blue Mountains is reflected as less than normal snowpack. Dry summer lightning storms are frequent throughout the southern Blues, and aspect is 
important in driving moisture and temperature. South-facing slopes have higher surface temperature and lower relative humidity than north-facing slopes, especially on steep slopes (>50\%; Heyerdahl et al. 2001).

a.

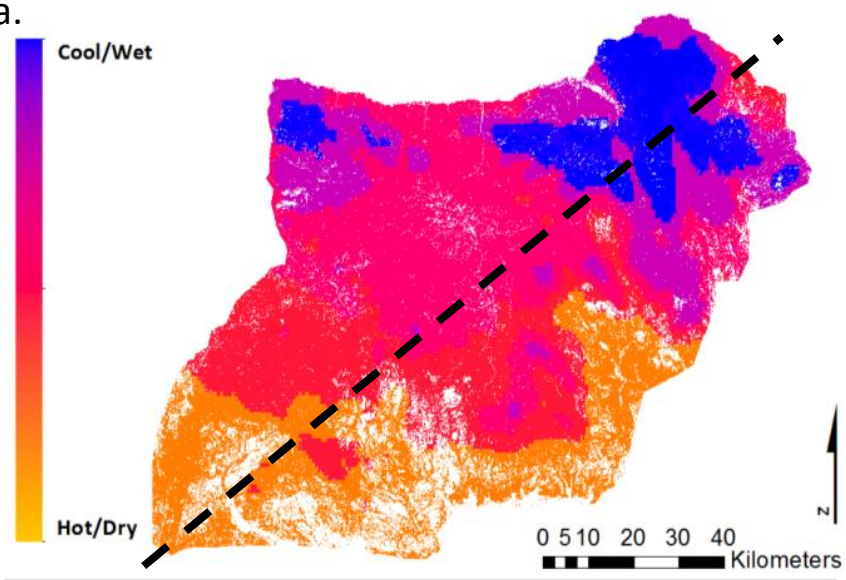

b
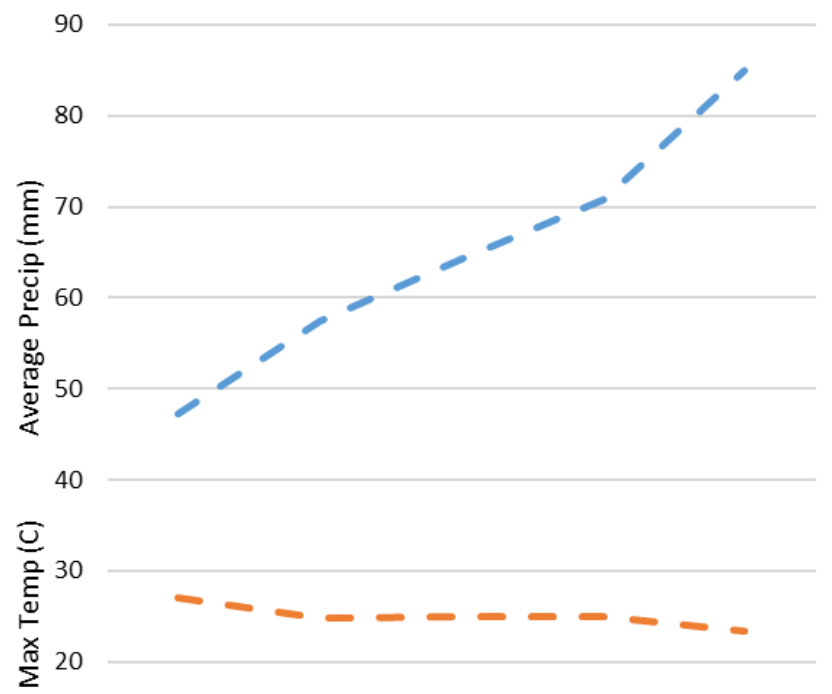

10

0

$$
\begin{gathered}
\text { Southwest } \quad-\text { Northeast } \\
-\quad-\text { Temp }- \text { Precip }
\end{gathered}
$$

Figure 2.3. Ecoregions and climate gradients developed from measured daily weather data from 1979 - 2014. (a) Twenty five ecoregions are determined by a combination of summer (June, July, August) mean maximum daily temperature and mean precipitation and by soil available water supply. Dashed line indicates the SW to NE gradient (b) Maximum summer temperatures 
decreased by $3.62{ }^{\circ} \mathrm{C}$ and average summer precipitation increased by $37.77 \mathrm{~mm}$ from the southwest to the northeast. Data are from the period $1979-2010$.

Forest association zones in the Blue Mountain region are Juniperus occidentalis, Pinus ponderosa, Abies grandis and Abies lasiocarpa (Franklin and Dyrness 1973). Current forested communities consist primarily of dry Pinus ponderosa (ponderosa pine) and dry mixed-conifer, which is dominated by a mix of ponderosa pine, Pseudotsuga menziesii var. glauca (rocky mountain Douglas fir here-after referred to as Douglas fir), Abies grandis (grand fir), and Larix occidentalis (western larch). Juniperus occidentalis (western juniper) is present in both forest types, although it is not dominant. At higher elevations, Abies lasiocarpa (sub-alpine fir), Pinus contorta var. latifolia (lodgepole pine) and Picea engelmannii (Engelmann spruce) are present, and both Pinus albicaulis (whitebark pine) and Pinus monticola (western white pine) are found in limited populations. Riparian areas contain Populus tremuloides (trembling aspen) as well as deciduous shrub species (e.g., Vaccinium spp., Salix spp.) and encroaching young conifers resulting from fire suppression, ungulate browse, and a lowered water table (Dwire et al. 2017) as well as scattered relict conifers greater than 120 years of age. Both low and high-elevation shrublands are dominated by Artemesia spp. (sagebrush) and Purshia tridentata (antelope bitterbrush; LEMMA, 2014).

This area is burned by frequent wildfires and is shaped by a legacy of commercial timber harvest (Heyerdahl and Agee 1996) as well as large-scale restoration efforts (USDA Forest Service, Malheur National Forest 2015) making it an appropriate case study to examine the influence of climate on forest dynamics and wildfire in a managed 
landscape. The historical fire regime, prior to the advent of aggressive fire suppression around 1900, was frequent with mean fire return intervals between $10.6-28.2$ years across both Ponderosa pine-dominated and mixed-conifer sites (Heyerdahl 1997, Johnston et al. 2016). More recent fire frequency is mediated by active fire suppression, but there continues to be an average of 1.6 fires per year within the study area boundaries and an average of 13,200 ha burned annually for the period $2000-2015$ (Monitoring Trends in Burn Severity 2017). To capture areas of forest and the surrounding grass and shrublands that provide continuous fuels for fire spread, the geographic boundaries of the study site are U.S. Hwy 26 to the north, U.S. Hwy 20 to the south with a buffer to the east and west of the Malheur National Forest that ranges from approximately $2-30 \mathrm{~km}$.

\subsubsection{Overview of simulation model}

Changes in forest and fuel bed characteristics over time were simulated with the dynamic FLM LANDIS-II (Scheller et al. 2007), which is widely used to simulate forest succession and interactions with disturbances such as fire, harvest, wind, and insects (Scheller et al. 2008, Lucash et al. 2014, Duveneck et al. 2014, Kretchun et al. 2014, 2016, Lucash et al. 2017, Loudermilk et al. 2017). LANDIS-II uses the life history traits of tree and shrub species, along with soil and climate data, to simulate successional trajectories and responses to disturbances over time. Trees are simulated as species-age cohorts, which represent all individual trees of each species as a single group within an age range (e.g., for this study trees were grouped into 10-year age cohorts). Each cell 
represents a simulation site on the landscape of $200 \times 200 \mathrm{~m}$ (4 ha), in which all forested vegetation and topographical conditions are assumed to be homogeneous. Sites can be active or inactive, such as in the case of open water or rocky outcroppings. Processes, such as reproduction, competition, growth, disturbance, and mortality, are simulated both within and between sites (Figure 2.4). LANDIS-II v6.2 was used with the Net Ecosystem Carbon and Nitrogen (NECN) succession (v4.2) and the Dynamic Fire and Fuels System (v4.0) extensions with outputs including biomass of individual species (i.e., as species-age cohorts), fuel types, and fire severity for each individual cell on the landscape. The Biomass Harvest (v3.2) extension simulated tree harvest at current levels in the southern portions of the Malhuer and Wallowa-Whitman National Forests and surrounding forested landscape.

\subsubsection{Model inputs}

\subsubsection{Ecoregions}

Soil and weather data were used to classify the landscape into 25 ecoregions that are assumed to have homogeneous climate and moisture conditions. Soil available water was assigned to each cell using SSURGO soil data where they were available;

where they were not, SSURGO provisional data and Soil Resource Inventory (SRI) data (Jay Noller, Chris Ringo, Karen Bennett, unpublished data) were used. Cells were reclassified into five soil moisture classes using Natural (Jenks) Breaks in ArcGIS 10.4.1. Maximum temperature and average precipitation for growing season months (June, July, and August) were obtained as 30-year normals (1980 - 2010; PRISM Climate 
Group) and reclassified into five climate regions using Iso Cluster Unsupervised

Classification in ArcMap 10.3 and nested within the soil moisture regions to create the final ecoregions as pictured in Figure 2.3a.

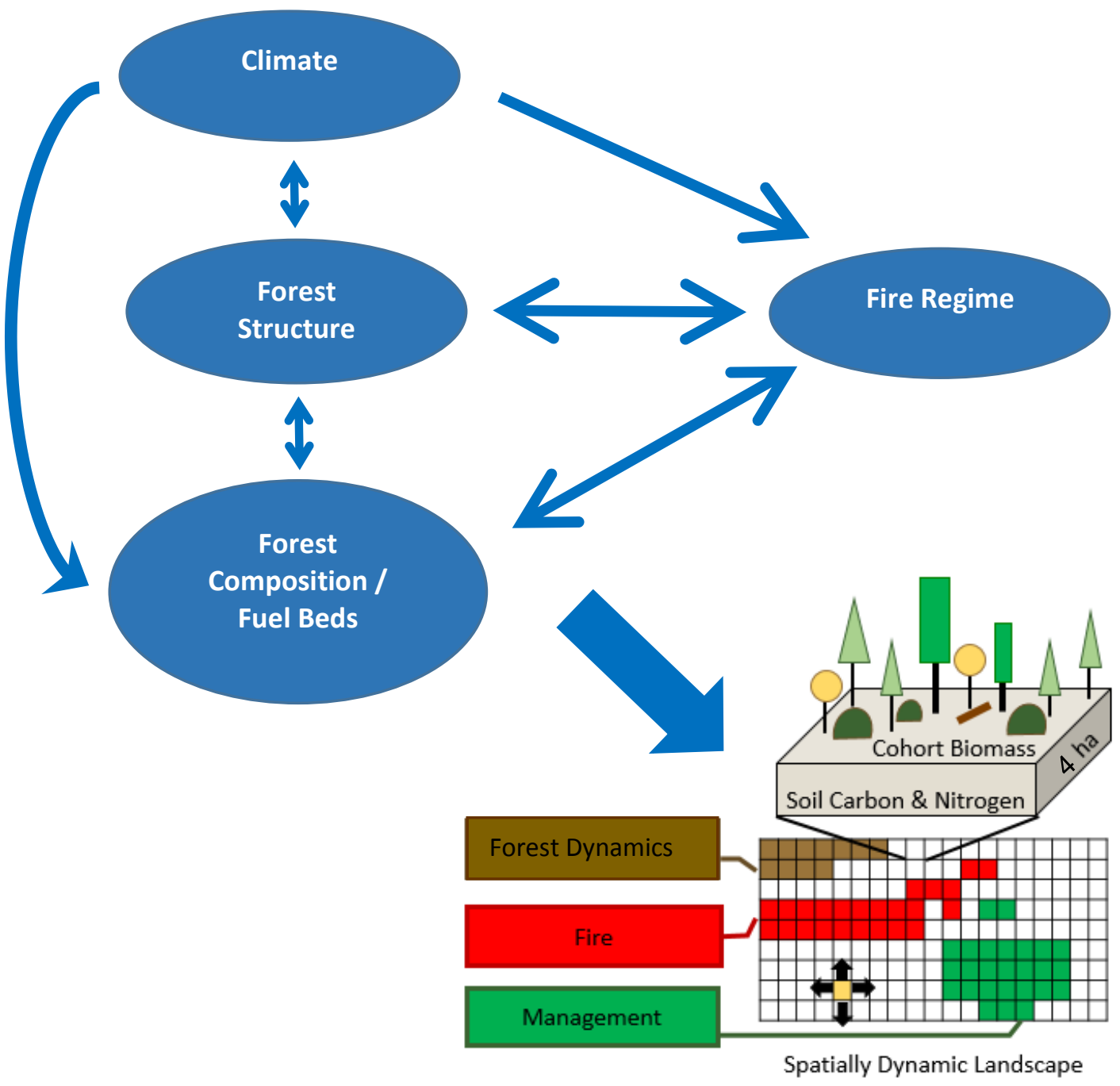

Figure 2.4. Conceptual model and dynamic modeling design. Relationships among climate, forest structure, forest composition and fuel beds, and fire regimes are complex, operating at multiple temporal and spatial scales and with feedbacks. These inter-related factors are modeled in the LANDIS-II forest landscape model (FLM), which integrates forest successional dynamics with management and disturbance events across space and time. Processes occur within and across each 4-ha cell. The NECN Succession extension simulates complex biophysical above and belowground processes. 


\subsubsection{Weather Data}

For contemporary weather I used daily weather data retrieved from the USGS Data Portal (maximum and minimum temperatures $\left({ }^{\circ} \mathrm{C}\right.$ ), average precipitation ( $\mathrm{mm} /$ day), daily average wind speed (m/s; (Maurer et al. 2002), and wind direction (degrees clockwise from north; Abatzoglou, 2013) for the period 1979 - 2010, using area-weighted grid statistics for each of the five climate regions.

For climate change scenarios, bias corrected constructed analogs V2 daily CMIP5 climate projections for general circulation models (GCMs) from both 4.5 and 8.5 representative concentration pathways (RCPs) were selected to represent the range of climate projections for both moderate and high emissions future trajectories. For the 38 GCMs with the full range of downscaled data through 12/31/2100 available through the USGS Data Portal, slope was calculated for the change in precipitation and maximum temperature over the period $2010-2100$, and I selected the four GCMs with the least and greatest slope for both parameters. In order to incorporate the uncertainty in future temperature increases and the direction and strength of precipitation trends produced by different GCMs, I randomly selected an additional 16 GCMs from those remaining for a total of 10 RCP 4.5 models and 10 RCP 8.5 models (Figures $2.5-2.7$ ). Area-weighted statistics were used to assign daily weather to each of the five climate regions. 


\section{GCM Precipitation and Temperature Slopes}

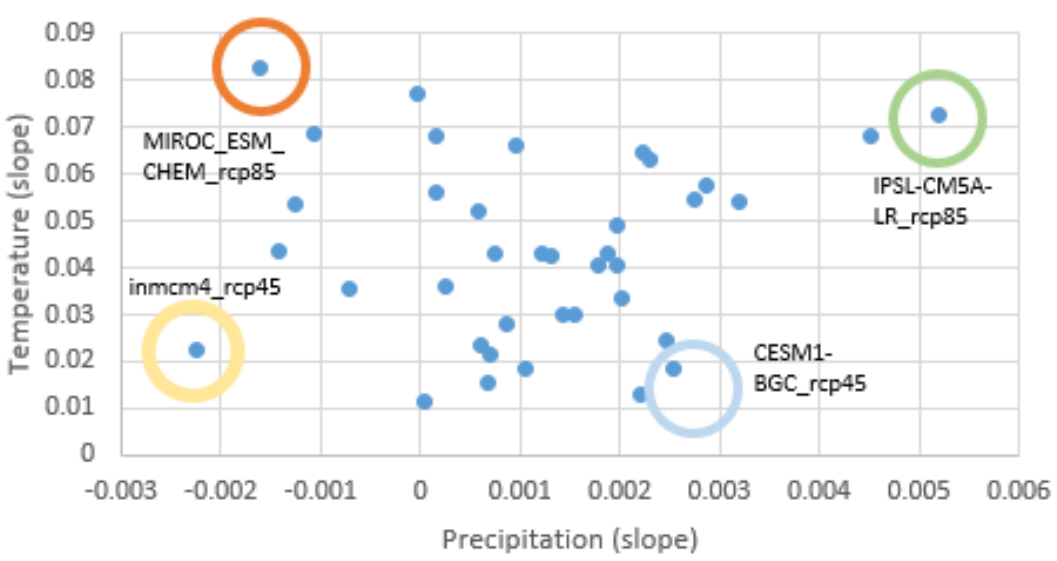

Figure 2.5. General circulation models (GCMs) were selected to represent the hottest/driest, hottest/wettest, coolest/driest and coolest/wettest projected conditions from the period 2010 2100. An additional $16 \mathrm{GCMs}$ were randomly selected from those remaining for a total of $10 \mathrm{RCP}$ 4.5 GCMs and 10 RCP 8.5 GCMs.

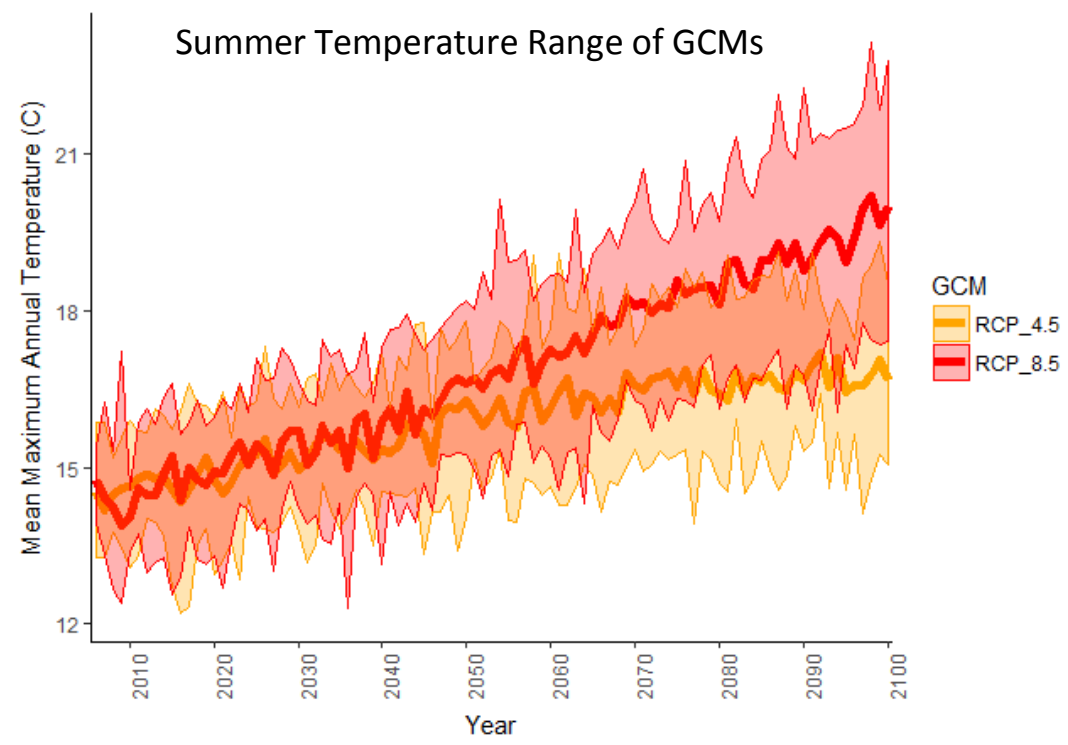

Figure 2.6. Range of maximum annual temperatures for all RCP 4.5 (orange) and RCP 8.5 (red) general circulation models used in simulations. The means are shown in thick lines while the range of values are shaded. Temperatures are similar until the fourth decade when they begin to diverge with RCP 8.5 temperatures rising more steeply and with greater variability among individual climate models. 


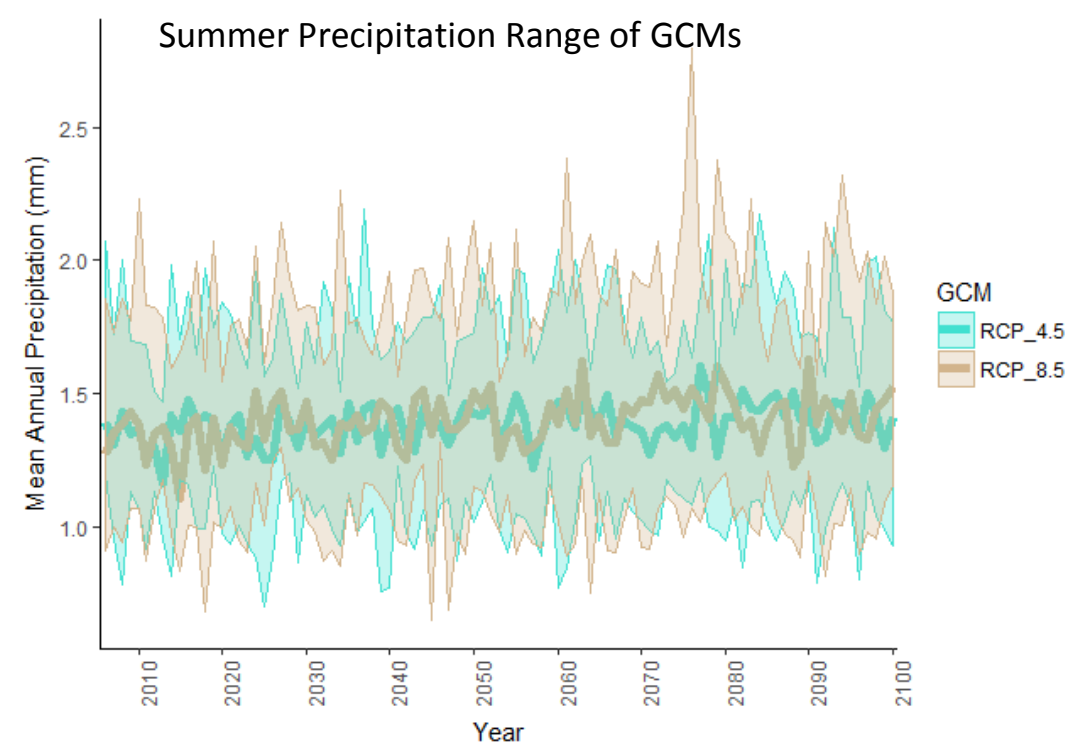

Figure 2.7. Range of annual precipitation for all RCP 4.5 (turquoise) and RCP 8.5 (tan) general circulation models used in simulations. The means are shown in thick lines while the range of values are shaded.

\subsubsection{Vegetation}

LANDIS-II simulates tree and shrub competition and regeneration in each site on the landscape. As a starting point, initial vegetation communities are assigned to each site. Vegetation data were obtained from the Gradient Nearest Neighbor (GNN) maps from the Landscape Ecology, Modeling, Mapping and Analysis (LEMMA) group (forested areas, Landsat imagery date 2012; https://lemma.forestry.oregonstate.edu/data/home) and the GAP Analysis Program's Ecological Systems map (unforested areas, Landsat ETM+ imagery 1999 - 2001);

https://gapanalysis.usgs.gov/gaplandcover/data/download/). There were 29 tree species identified in forested cells, and species that occurred on at least $0.4 \%$ of the landscape were included in this study (11 species, Table 2.1 ). These species were 
grouped into species-age cohorts in 10 -year bins. There were 4,631 unique communities on the landscape, each with up to 11 tree species.

Non-forest cells were assigned to 44 categories from the GAP Analysis Program's Ecological Systems map and were then grouped into five unique non-forest categories based on similar vegetation and fuel characteristics (Disturbed and Invaded Grasslands; Perennial Grasslands; Sagebrush Shrublands; Deciduous Shrublands [Not Flammable]; and Deciduous Riparian Shrublands [Flammable]) and one inactive category that was not simulated (e.g., open water, bedrock and scree). Using NatureServe Explorer (http://explorer.natureserve.org/servlet/NatureServe?init=Ecol), 45 shrub species that occur in the GAP-identified ecosystem categories in the Blue Mountain region were identified and reclassified into functional groups based on whether they 1 . are nitrogen fixing, 2. resprout after fire, and 3. are shade tolerant (Table 2.2). Non-forested cells (e.g., sagebrush shrublands, perennial grasslands, etc.) were assigned cohorts of these shrub-groups based on the combinations of individual shrub species that occur in each non-forest category. Shrubs were also included in forested cells according to the GNN Understory inventory data. Disturbed and Invaded Grasslands and Perennial Grasslands were assigned invasive and native grasses respectively in order to provide grass fueltypes and allow fires to spread through cells that do not contain either trees or shrubs. 
Table 2.1. Species life history trait input parameters. Shade tolerance and fire tolerance are ordinal scales where 1 is the least tolerant and 5 is the most tolerant. Shrub category names are shortened. See Table 2.2 for descriptions of shrub categories.

\begin{tabular}{|c|c|c|c|c|c|c|c|c|c|c|}
\hline Species & $\begin{array}{l}\text { Max. } \\
\text { Age } \\
\text { (years) }\end{array}$ & $\begin{array}{l}\text { Seed- } \\
\text { ing Age } \\
\text { (years) }\end{array}$ & $\begin{array}{l}\text { Shade } \\
\text { Toler- } \\
\text { ance }\end{array}$ & $\begin{array}{l}\text { Fire } \\
\text { Toler- } \\
\text { ance }\end{array}$ & $\begin{array}{l}\text { Effective } \\
\text { Seeding } \\
\text { Distance } \\
\text { (m) }\end{array}$ & $\begin{array}{l}\text { Max. } \\
\text { Seed- } \\
\text { ing } \\
\text { Dist- } \\
\text { ance } \\
\text { (m) }\end{array}$ & $\begin{array}{l}\text { Prob. of } \\
\text { Resprout }\end{array}$ & $\begin{array}{l}\text { Min. } \\
\text { Resprout } \\
\text { Age } \\
\text { (years) }\end{array}$ & $\begin{array}{l}\text { Max. } \\
\text { Resprout } \\
\text { Age } \\
\text { (years) }\end{array}$ & $\begin{array}{l}\text { Post-Fire } \\
\text { Regen }\end{array}$ \\
\hline $\begin{array}{l}\text { Abies grandis/ } \\
\text { Abies } \\
\text { concolor }\end{array}$ & 300 & 20 & 4 & 3 & 30 & 300 & 0 & 0 & 0 & none \\
\hline $\begin{array}{l}\text { Abies } \\
\text { lasiocarpa }\end{array}$ & 200 & 20 & 5 & 1 & 30 & 80 & 0 & 0 & 0 & none \\
\hline $\begin{array}{l}\text { Cercocarpus } \\
\text { ledifolius }\end{array}$ & 600 & 10 & 2 & 2 & 30 & 400 & 0.2 & 1 & 120 & resprout \\
\hline $\begin{array}{l}\text { Juniperus } \\
\text { occidentalis }\end{array}$ & 1000 & 50 & 2 & 3 & 2 & 30 & 0 & 0 & 0 & none \\
\hline $\begin{array}{l}\text { Larix } \\
\text { occidentalis }\end{array}$ & 700 & 25 & 1 & 5 & 100 & 250 & 0 & 0 & 0 & none \\
\hline $\begin{array}{l}\text { Picea } \\
\text { engelmannii }\end{array}$ & 400 & 30 & 4 & 1 & 90 & 180 & 0 & 0 & 0 & none \\
\hline $\begin{array}{l}\text { Pinus } \\
\text { albicaulis }\end{array}$ & 900 & 30 & 3 & 2 & 30 & 5000 & 0 & 0 & 0 & none \\
\hline $\begin{array}{l}\text { Pinus } \\
\text { contorta }\end{array}$ & 200 & 5 & 2 & 2 & 30 & 300 & 0 & 0 & 0 & none \\
\hline $\begin{array}{l}\text { Pinus } \\
\text { ponderosa }\end{array}$ & 600 & 7 & 1 & 4 & 30 & 160 & 0 & 0 & 0 & none \\
\hline $\begin{array}{l}\text { Populus } \\
\text { tremuloides }\end{array}$ & 150 & 10 & 2 & 2 & 100 & 1000 & 0.9 & 1 & 145 & resprout \\
\hline $\begin{array}{l}\text { Pseudotsuga } \\
\text { menziesii }\end{array}$ & 300 & 20 & 4 & 3 & 30 & 300 & 0 & 0 & 0 & none \\
\hline Toleresp & 60 & 3 & 3 & 1 & 30 & 1000 & 0.85 & 5 & 50 & resprout \\
\hline Intoresp & 60 & 3 & 2 & 1 & 30 & 500 & 0.85 & 5 & 50 & resprout \\
\hline Nonnseed & 80 & 5 & 2 & 1 & 30 & 250 & 0 & 0 & 0 & none \\
\hline Fixnresp & 80 & 5 & 1 & 1 & 20 & 250 & 0.75 & 5 & 70 & resprout \\
\hline Native grasses & 100 & 1 & 4 & 1 & 1000 & 5000 & 1.0 & 0 & 100 & resprout \\
\hline $\begin{array}{l}\text { Invasive } \\
\text { grasses }\end{array}$ & 100 & 1 & 4 & 1 & 1000 & 5000 & 1.0 & 0 & 100 & resprout \\
\hline
\end{tabular}

Table 2.2. Shrub categories. Species included in each category are available in the supplemental material.

\begin{tabular}{|l|l|l|l|}
\hline Category & Shade Tolerant & Nitrogen Fixing & Resprout After Fire \\
\hline Toleresp & Yes & No & Yes \\
\hline Intoresp & No & No & Yes \\
\hline Nonnseed & No & No & No \\
\hline Fixnresp & No & Yes & Yes \\
\hline
\end{tabular}




\subsubsection{Model parameterization and validation}

\subsubsection{Forest succession}

The Net Ecosystem Carbon and Nitrogen Succession (NECN) extension in LANDISII includes aboveground and belowground $\mathrm{C}$ and $\mathrm{N}$ pools that follow the CENTURY soil model (Parton et al. 1993). Temperature and precipitation at monthly time-steps control vegetation growth and reproduction. Model parameters were obtained from the literature and available datasets including the USDA Fire Effects Information System (https://www.feis-crs.org/feis/), USGS Vegetation Atlas of North America (https://pubs.usgs.gov/pp/p1650-a/), the Northeastern Ecosystem Research Cooperative's Foliar Chemistry Database (http://www.nercscience.org/Metadata_FoliarChemistry.html), the National Atmospheric Deposition Program (http://nadp.sws.uiuc.edu/NTN/ntnData.aspx), the Oak Ridge National Laboratory database (https://daac.ornl.gov/SOILS/guides/West Soil Carbon.html), and from previous studies that utilized LANDIS-II species parameterization (Loudermilk et al. 2014, Lucash et al. 2014, Creutzburg et al. 2016).

NECN Succession "spins up" to the start year of the simulation by iterating succession at the number of time steps equal to the oldest cohort in each site allowing comparison between simulated and observed biomass. Growth and biomass validation was accomplished by comparing aboveground tree biomass (total and species-specific) with Forest Inventory Analysis (FIA) data. Simulated total biomass ranged from 0 to 105 
$\mathrm{Mg} / \mathrm{ha}$ with a mean value of $45 \mathrm{Mg} / \mathrm{ha}$, while biomass estimates from FIA data ranged from $0-236 \mathrm{Mg} / \mathrm{ha}$ with a mean of $45 \mathrm{Mg} / \mathrm{ha}$. These results show that while the model did not simulate the full range of variability in total biomass, it sufficiently captured average biomass and adequately reproduced tree growth. Validation of each of the 11 modeled tree species was performed by comparing average species-level biomass, only in cells where that species occurs, with GNN data for that species. Out of the 11 tree species simulated, nine achieved average biomass within 30\% of GNN (Figure 2.8).

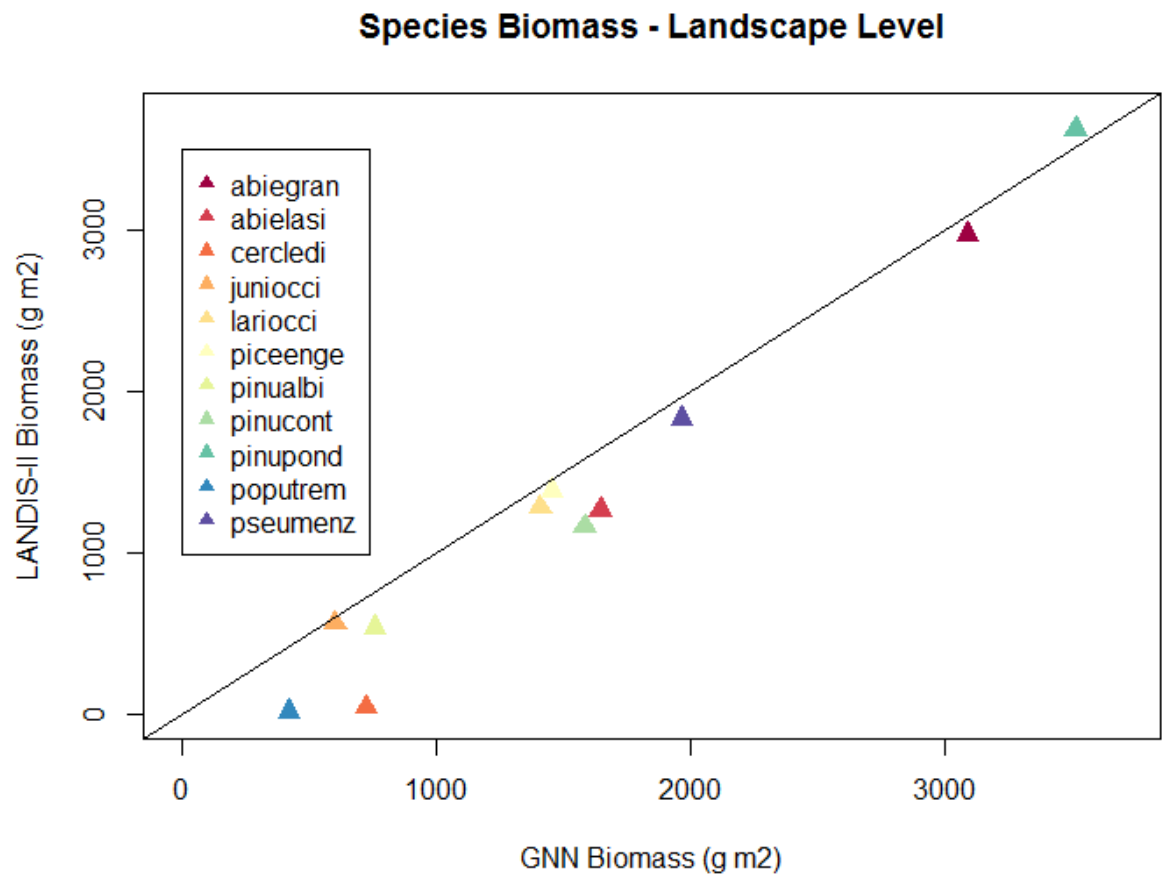

Figure 2.8. Initial biomass $\left(\mathrm{g} \mathrm{m}^{-2}\right)$ at time zero as a measure of model validity. LANDIS-II tended to slightly underestimate biomass but achieved average biomass within $30 \%$ of GNN biomass for all but two species (Populus tremuloides and Cercoparpus ledifolius, both which constitute minor components of landscape forest composition).

\subsubsection{Wildfire}

The Dynamic Fire and Fuels extension (Sturtevant et al. 2009) simulated wildfire and interactions with climate and fuels. This extension uses the same climate and 
vegetation as NECN, which allows it to dynamically change fuel beds based on vegetation at the corresponding timestep to direct fire spread and severity. Fuel types were developed to represent 15 unique combinations of tree species and ages, as well as shrublands and grasslands, with individual ignition probabilities and fire behavior parameters. Landscape topography was integrated via slope and aspect maps.

Fire was calibrated to approximate annual area burned (mean 9,706 ha, median 615 ha, range of $0-81,010$ ha, standard deviation 24,481 ha) and fire size (mean 6,933 ha with a range of $434-56,484$ ha) for the period $2000-2014$ in the study area. (Multiple small fires with the same wildfire designation were considered one fire.) This 15-year period was selected because it reflects the most recent fire activity on the study landscape allowing calibration of the model to reflect current conditions. Historical fire data were retrieved from the Monitoring Trends in Burn Severity database (2016) and the USDA Forest Service (Blue Mountains Fire History Polygons, released 2016). Simulated fire sizes were first calibrated by limiting the maximum fire size to achieve a distribution equivalent to the historical period and to reconstruct fire duration from these simulated fires. Calibration simulations were then run as duration-limited, which allows for the possibility of larger fires and greater annual area burned reflecting the influence of dynamic vegetation and weather over time (Sturtevant et al. unpublished). The DFFS extension uses log-normal duration data to generate the distribution of fire durations, and this derived duration distribution was then used to calibrate annual area burned, which also follows a log-normal distribution. Three replicates of 50 years were 
run and averaged to validate the calibration, achieving a mean of 10,400 ha burned annually with a range of $0-134,700$ ha (Figure 2.9 ).

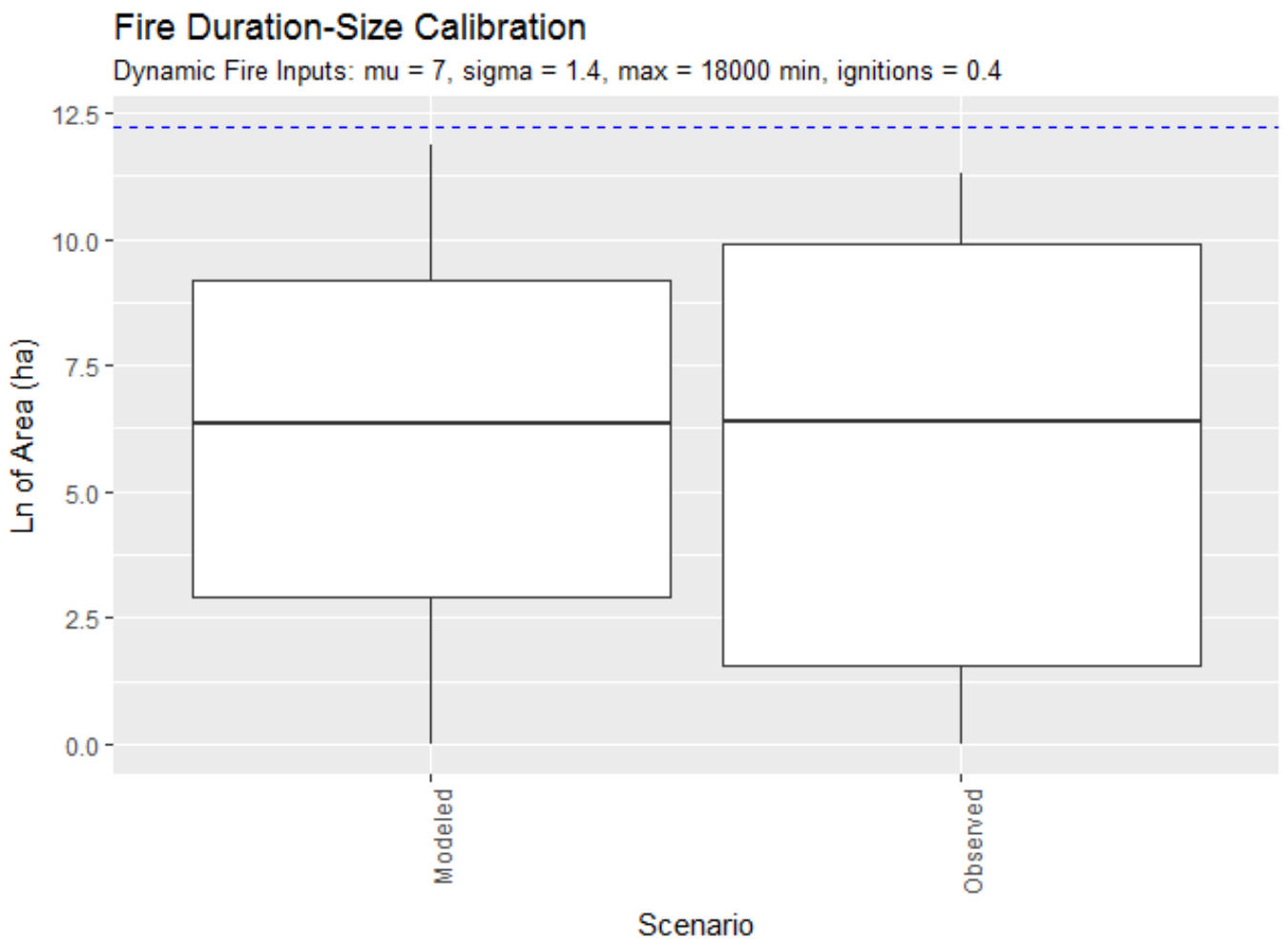

Figure 2.9. Fire calibration was achieved through modeling the distribution of durations of individual fires, which follows a log-normal distribution, and calibrating duration to produce a log-normal distribution of annual area burned that is similar to the observed distribution. Modeled annual area burned has lower variability than observed over the period $2000-2014$ but closely matches log-median and range. Boxes encompass mean \pm 1 standard deviation, solid black line is the median, whiskers are the range, blue dotted line marks log-area burned of 12.22 (equivalent to 202,000 ha or 500,000 acres), which represents a realistic maximum for annual area burned under contemporary weather based on historical data for the surrounding region. Subtitle contains the parameter inputs for the Dynamic Fire and Fuels System where mu is the log-mean of duration, sigma is the standard deviation, max is the maximum duration of an individual fire in minutes, and ignitions is a calibrated value that controls the number of ignitions expected per year within each ecoregion (ignitions $x$ timestep $=\lambda$ for the Poisson distribution).

\subsubsection{Forest management}

The forested landscape of the study area is currently managed according to ownership. Harvest on private lands is primarily non-industrial, and harvest on publically 
managed lands, particularly those managed by the U.S. Forest Service, is generally designed to meet multiple objectives (e.g., to promote ecological integrity, social wellbeing, and economic well-being (U.S. Department of Agriculture, Forest Service 2014). To ensure that simulated management reflects on-the-ground actions, treatment prescriptions were developed through a workshop with managers (U.S. Forest Service) and expert consultation (Bureau of Land Management, Oregon Department of Forestry). The Biomass Harvest extension (v3.2) simulated management including commercial harvest, pre-commercial thinning, and prescribed fire. (See Table 2.3 for descriptions of prescriptions.) Management was kept constant across scenarios and over the 90 -year simulation period.

Table 2.3. Management prescriptions. Management includes harvest of trees, pre-commercial thinning and prescribed burning. Modeled prescriptions for U.S. Forest Service lands were developed with federal silviculturists and fuels managers. Prescriptions for Bureau of Land Management, Oregon State and Private Non-Industrial lands were developed through expert consultation.

\begin{tabular}{|lll|}
\hline Ownership & Forest type/Treatment & $\begin{array}{l}\text { Mean area treated } \\
\text { per decade (ha) }\end{array}$ \\
\hline Forest Service & $\begin{array}{l}\text { Ponderosa pine } \\
\text { Dry mixed conifer } \\
\text { Combination of commercial harvest and } \\
\text { restoration thinning followed by } \\
\text { prescribed fire }\end{array}$ & \\
\hline & $\begin{array}{l}\text { Moist mixed conifer } \\
\text { Combination of commercial harvest and } \\
\text { restoration thinning }\end{array}$ & 13,000 \\
\cline { 2 - 3 } & $\begin{array}{l}\text { All forest types } \\
\text { Pre-commercial thinning }\end{array}$ & 14,000 \\
\hline $\begin{array}{l}\text { Bureau of } \\
\text { Land } \\
\text { Management }\end{array}$ & $\begin{array}{l}\text { Ponderosa pine } \\
\text { Dry mixed conifer }\end{array}$ & $\begin{array}{l}1,040 \text { (includes both } \\
\text { timber sales and }\end{array}$ \\
\hline
\end{tabular}




\begin{tabular}{||lll|}
\begin{tabular}{|l} 
and Oregon \\
State
\end{tabular} & $\begin{array}{l}\text { Harvest commercial species (ages } 70- \\
140)\end{array}$ & $\begin{array}{l}\text { stewardship } \\
\text { contracts) }\end{array}$ \\
\hline $\begin{array}{l}\text { Private Non- } \\
\text { Industrial }\end{array}$ & $\begin{array}{l}\text { Ponderosa pine } \\
\text { Dry mixed conifer } \\
\end{array}$ & 7,200 \\
& $\begin{array}{l}\text { Harvest oldest cohorts of commercial } \\
\text { species }\end{array}$ & \\
\hline
\end{tabular}

\subsubsection{Scenarios}

I compared three different scenarios based on climate and replicated each scenario 10 times. For the contemporary weather scenario, each simulation year was assigned a random year of daily weather data drawn from 1979 - 2010 from the Gridded Observed Meteorological Data dataset (Maurer et al. 2002). Climate change scenarios included multiple GCMs per scenario in lieu of identical replicates to allow a better understanding of the range of future conditions as described above. Each scenario represents a possible future, dependent upon the degree to which greenhouse gas emissions are or are not curbed over the next 90 years.

\subsubsection{Analysis}

Statistical analysis was completed for annual area burned, fire severity, and biomass data. Annual area burned data followed a log-normal distribution, therefore analysis was conducted on log-transformed data. Following Bartlett's test for homoscedasticity, analysis of variance and Tukey's honestly significant difference tests were run to differentiate means. 
Change in biomass was calculated between the start-year and the end-year of simulations, and site community change was analyzed with multivariate statistical analysis using the vegan package (Oksanen et al. 2017) on one replicate for each climate scenario. The contemporary scenario replicate was chosen by a random number generator, and I selected the warm/wet RCP 4.5 GCM (CESM1-BGC) and the hot/dry RCP 8.5 GCM (MIROC-ESM-CHEM). These three replicates were used instead of all 30 replicates (which constitute 13,050,000 rows of data) because of the processing restraints of the R software and the vegan package. To further accommodate computational limitations, sites were resampled to a resolution of 1,600 ha and assigned the mean biomass of the combined cells.

To compare relative change in biomass for species composition, regardless of the abundance of each individual species, change-in-biomass data were relativized by maxima for each replicate, and two outlier sites were removed from analysis. To equally utilize change-in-biomass data across the landscape, sites were standardized by totals (McCune and Grace 2002). Biomass data were then converted into a Bray-Curtis dissimilarity matrix, which accounts for both presence/absence and abundance of individual species (Beals 1984), and permutational multivariate analysis of variance (PERMANOVA) was employed to identify the relative contributions of fire, temperature, precipitation, and other abiotic factors including elevation, slope, and soil type to changes in biomass (Anderson 2001). I converted continuous categorical data to zscores to avoid weighting their contribution due to unequal scale (e.g., temperature in 
degrees Celsius and elevation in thousands of feet), and I checked for multicollinearity among variables using Spearman's correlation coefficients and paired scatterplots (Figure 2.10). I built a PERMANOVA model via subtraction by starting with all explanatory variables and removing the ones that were not significant or that had extremely low explanatory power (i.e., that had a low $R^{2}$ value). Climate scenario was included as a blocking term. A final model was built with the strongest variables and their interaction terms.

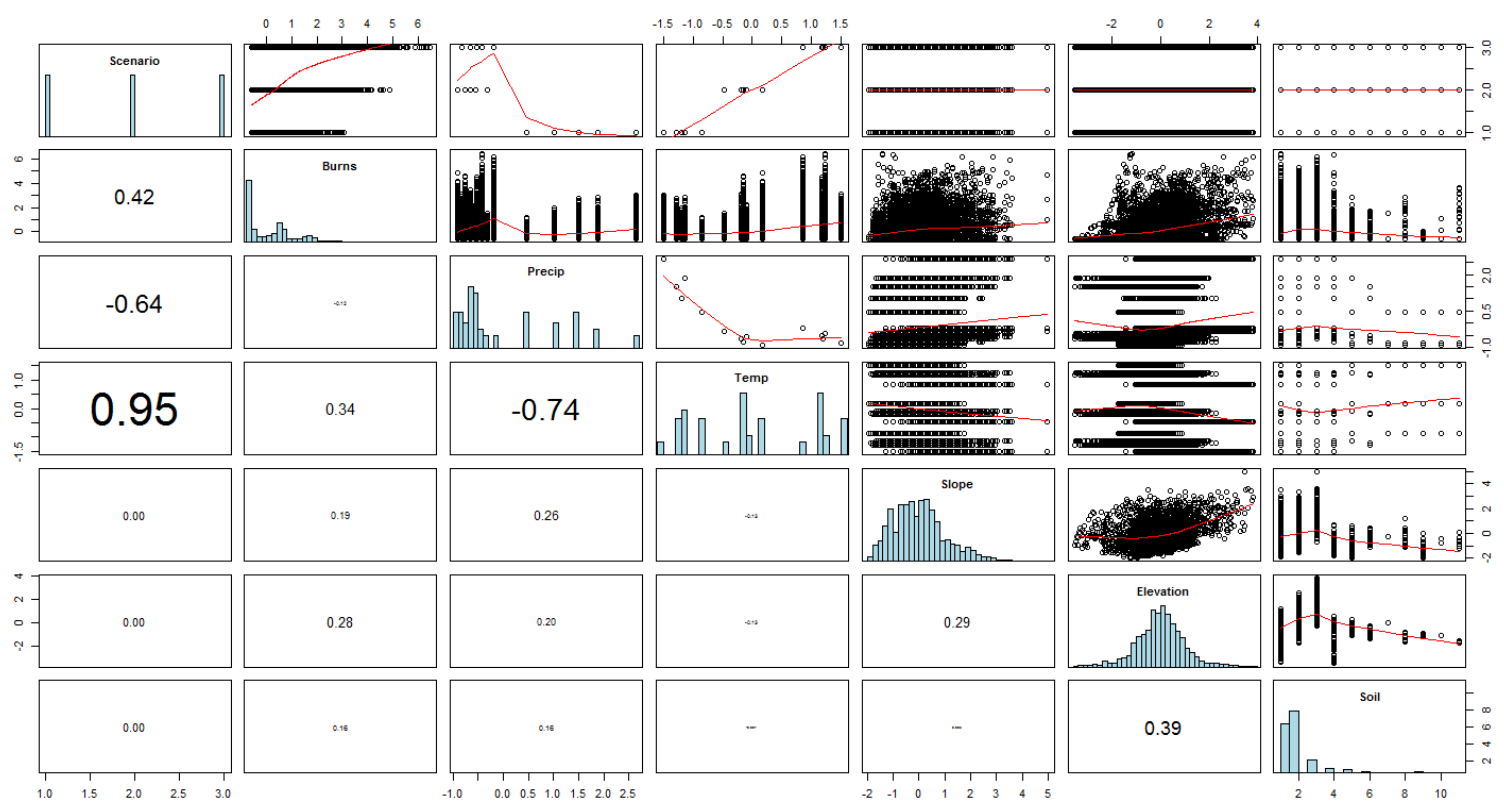

Figure 2.10. Correlation matrix of independent variables used in multivariate analysis of biomass change. Scenario is highly correlated with both temperature $\left(R^{2}=0.95\right)$ and precipitation $\left(R^{2}=-\right.$ $0.64)$, and temperature and precipitation are strongly negatively correlated with each other $\left(R^{2}=-0.74\right)$. Scenario and number of burns $\left(R^{2}=0.42\right)$, elevation and soil type $\left(R^{2}=0.39\right)$, and number of burns and temperature $\left(R^{2}=0.34\right)$ were moderately correlated. Number of burns was weakly correlated with elevation $\left(R^{2}=0.28\right)$ and soil type $\left(R^{2}=0.22\right)$. There were also weak correlations between precipitation and slope $\left(R^{2}=0.26\right)$ and elevation $\left(R^{2}=0.20\right)$, and between slope and elevation $\left(R^{2}=0.29\right)$.

Non-metric multi-dimensional scaling (NMDS), which can include co-variates as well as both continuous and categorical variables, was used to visualize multivariate 
responses to significant independent variables (McCune and Grace 2002). Ordination was run on the Bray-Curtis dissimilarity matrix with 1,000 iterations and 100 random initial coordinates in three dimensions. Convergence was not reached, however this is not uncommon for large datasets, and the stress of the final model was satisfactory at 0.109 (Clarke 1993), which was confirmed with a Shepard Plot (Figure 2.11). All model calibration and data analyses were completed in RStudio 1.0.153 using R x64 3.4.1.

\section{Shepard Plot}

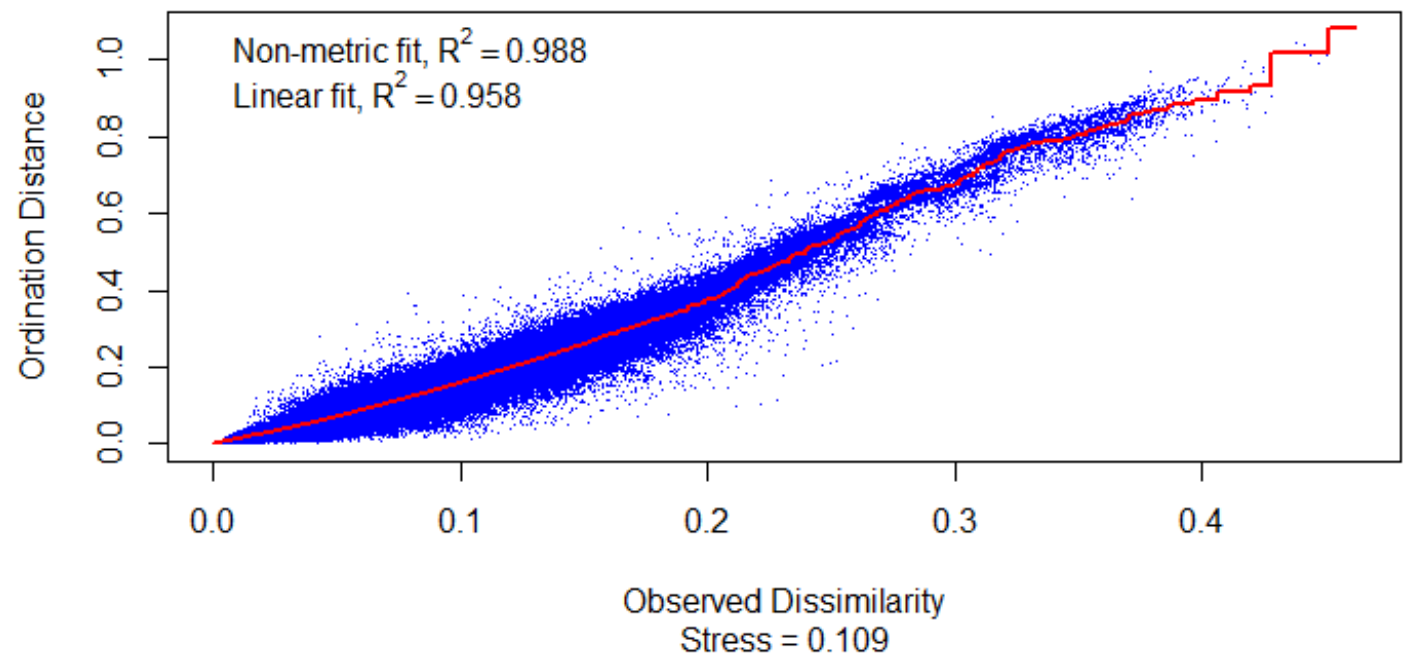

Figure 2.11. Shepard plot, which shows the non-metric and linear fit of observed dissimilarity and ordination distance for non-metric multi-dimensional scaling. Stress level of 0.109 is considered evidence of a good ordination with no real risk of drawing false inferences.

\subsection{Results}

\subsubsection{Wildfire}

Fire activity is more frequent, more extensive, and more severe under climate change than contemporary conditions. Fire rotation period, or the amount of time it would take an area equivalent to the size of the entire landscape to burn, was 149.6 
years under contemporary weather, 94.11 years under RCP 4.5 conditions, and 86.3

years under RCP 8.5 conditions, reflecting more frequent burning under increasing emissions. Annual area burned was generally stable over time under contemporary weather with a slight upward trend for the first four decades followed by a slow decline in the last sixty years. Under climate change, annual area burned rose for the first six decades before strongly declining toward the end of the century, although variability increased toward the end of the simulation period (Figure 2.12).

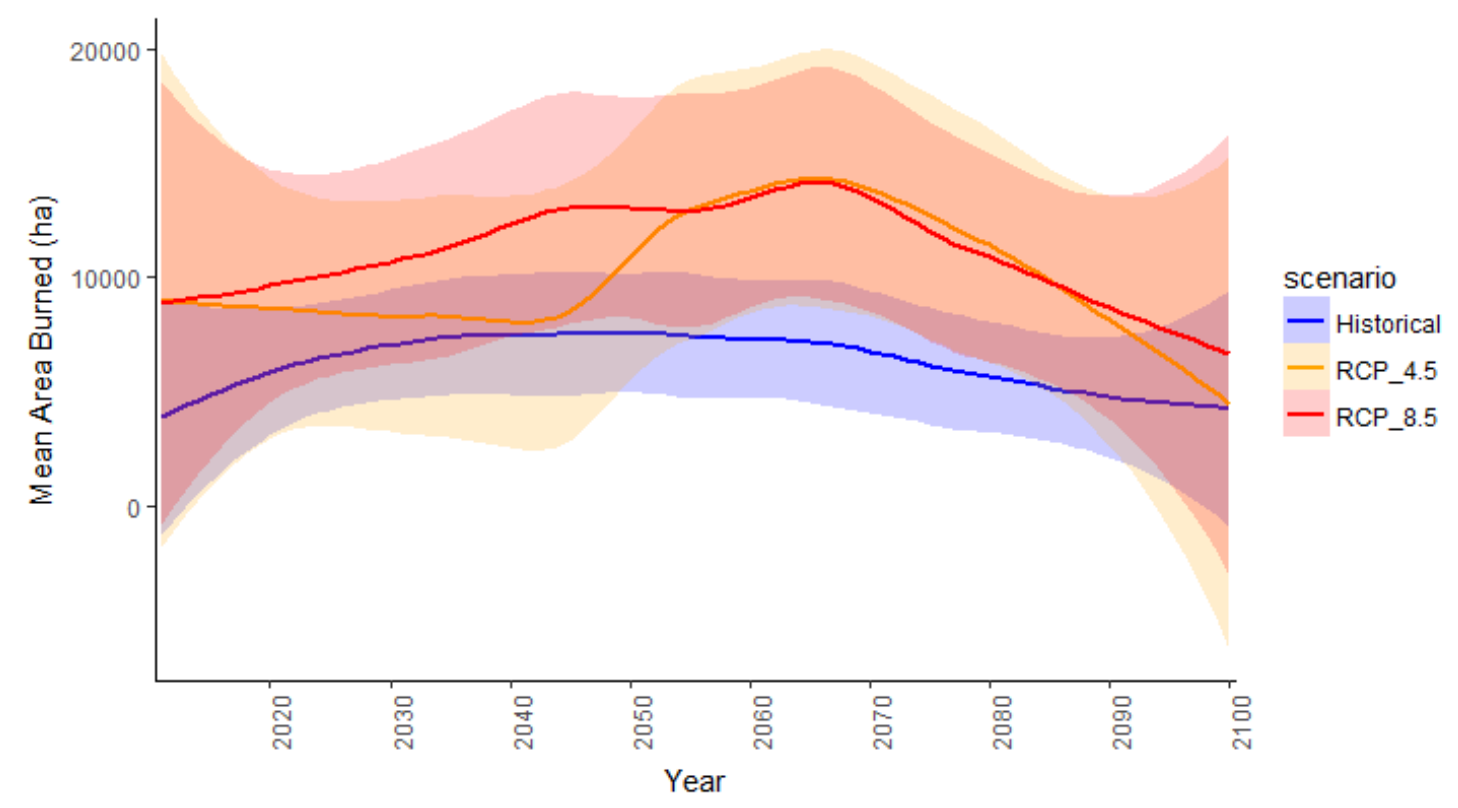

Figure 2.12. Annual area burned over time fitted with a locally weighted scatterplot smoother (LOWESS) curve. Area burned was generally stable over time under contemporary weather, but area burned increased over time under climate change until the $6^{\text {th }}$ decade when it began to decrease. Variability in annual area burned was influenced by individual large events.

Annual area burned was significantly larger under the higher emissions scenario than under contemporary climate $(p=0.02)$. There was no significant difference between area burned under the two climate change scenarios, although RCP 8.5 had 
higher variability (Figure 2.13). On average, 6,272 ha burned per year under historical conditions with a range from 0 to 245,016 ha. Under climate change, annual area burned averaged 9,970 ha with a range of 0 to 542,212 ha (RCP 4.5) and 10,873 ha with a range of 0 to 551,472 ha (RCP 8.5), more than double the most extreme extent of wildfire in a single year under contemporary weather. Under climate change, there was also an increase in the number of "extreme fire years," here defined as years with at least 40,000 ha $(100,000$ acres) burned. Under contemporary weather, $3.9 \%$ of simulation-years were extreme fire years, while under both emissions scenarios, $6 \%$ of simulated years were extreme.

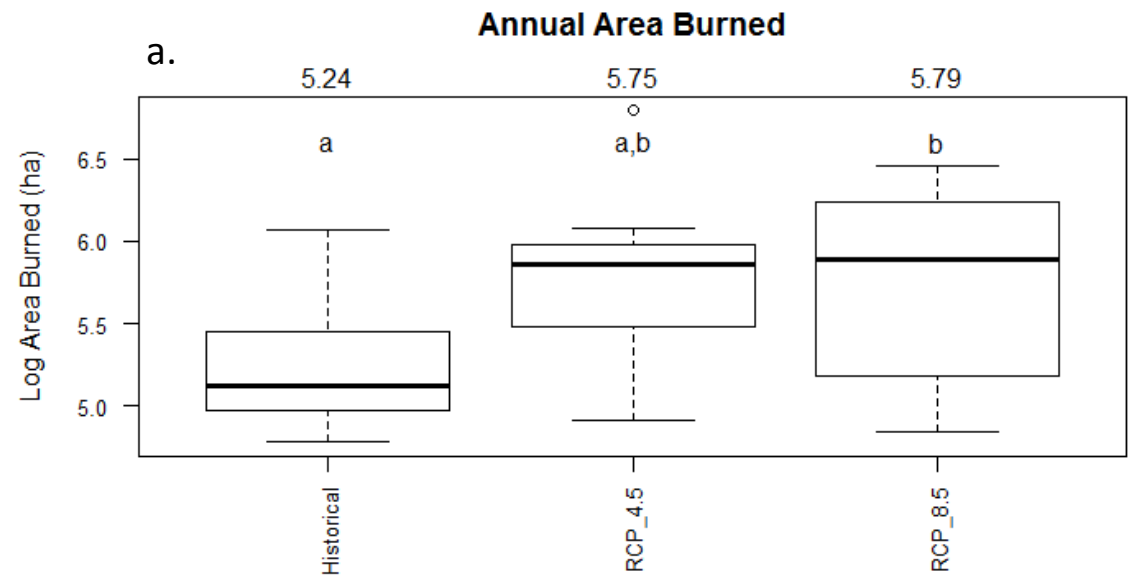

b.

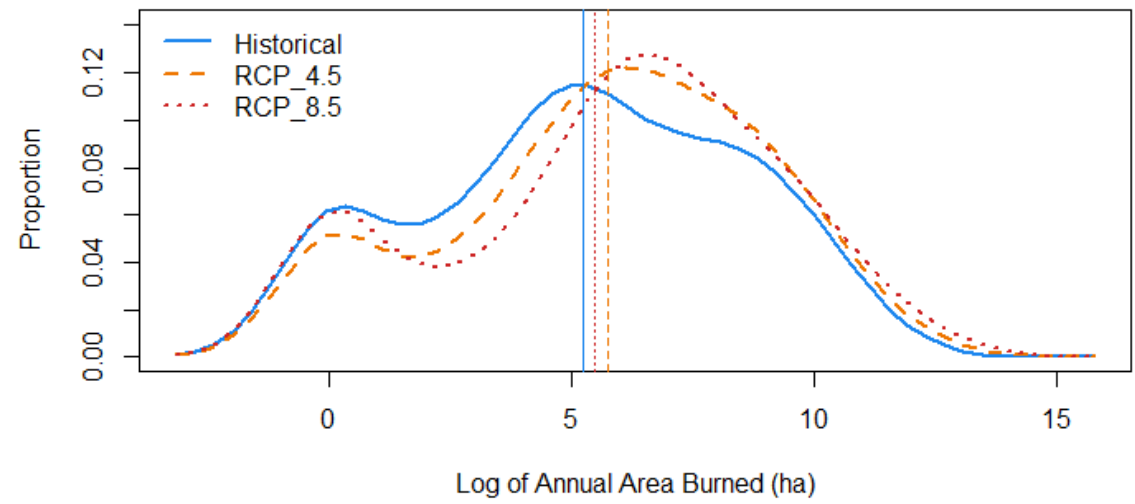


Figure 2.13. Annual area burned for the last 30 years of simulations under contemporary weather and climate change scenarios. Annual area burned under the highest emissions scenarios was significantly higher than Contemporary $(p=0.029)$, and was more variable across replicates. The difference between Contemporary and RCP 4.5 was not significant $(p=0.07)$, and there was no difference between the two emissions scenarios $(p=0.98)$. Boxplots $(a$.) show the greater variability in area burned for the RCP 8.5 scenario. Boxes encompass the $25^{\text {th }}$ and $75^{\text {th }}$ percentile and whiskers extend to 1.5 times the interquartile range. Outliers are indicated by a circle. The density plot (b.) shows the proportion of years with annual area burned with values on the $\mathrm{x}$-axis transformed by the natural log, and log-mean values for each scenario illustrated by vertical lines.

The likelihood of fire at any given site also increased with climate change. Under the Contemporary scenario, the mean probability that a single cell would burn in any given year was 0.007 , under RCP 4.5 it was 0.011 , and under RCP 8.5 it was 0.012 . Additionally, higher probability of burning occurred in the northeastern portion of the landscape in all scenarios, but under both climate change scenarios, there was a greater likelihood of fire across the landscape, including the central and western portions

(Figure 2.14).

\section{Probability of Fire}
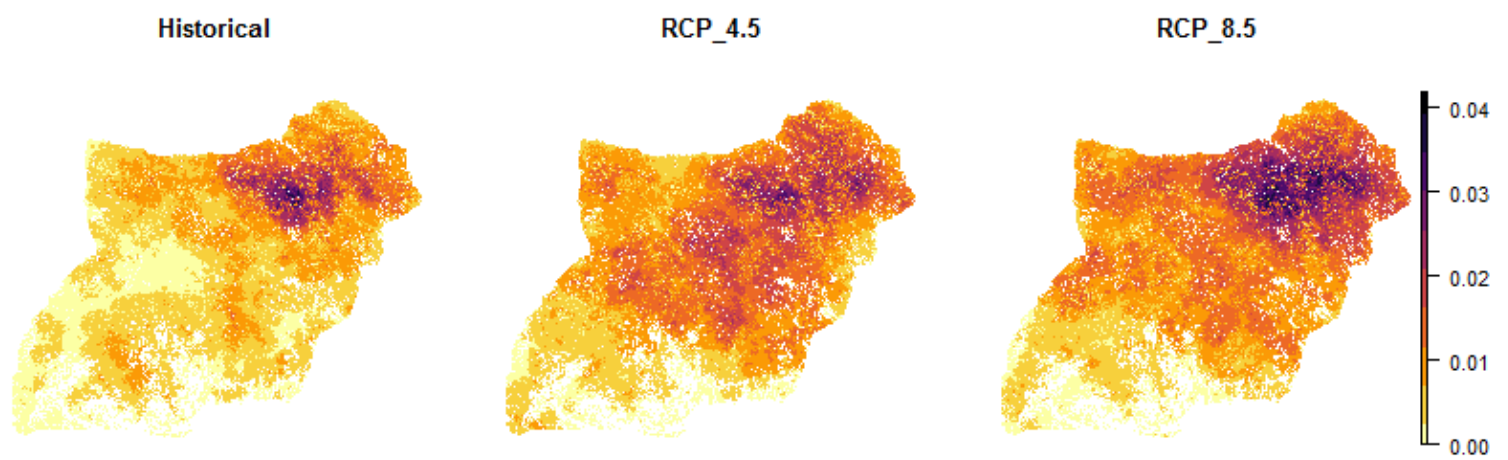

Figure 2.14. Maps of probability that each individual site will burn during any given year under contemporary weather and climate change projections. Scale represents the probability of burning of each individual cell over 90 years and 10 replicates. Fire is more likely across a greater proportion of the landscape under increasing emissions scenarios, especially in the northeast portion, of the landscape. 
Fire severity was higher under climate change $(p=0.02)$ than contemporary weather (mean severity 3.22), but did not differ between RCP 4.5 and 8.5 (mean severity 3.4 and 3.39 respectively, Figure 2.15$)$. Under climate change, $81.6-83.7 \%$ of the landscape burned with a high severity fire (severity of 4-5) at least once, while under historical conditions, only $58.9 \%$ did. The highest severity fires occurred most often in the north-eastern portion of the landscape in forests dominated by high-elevation species (sub-alpine fir, whitebark pine, Engelmann spruce; Figure 2.16). Outside of forested areas, fires were typically high-severity as measured by the LANDIS-II model (i.e., though a combination of the fire's rate of spread and potential mortality), however as those areas are shrub and grass-dominated, and therefore contain fuel types that are highly flammable, these high severity fire were expected. 
a.

Fire Severity

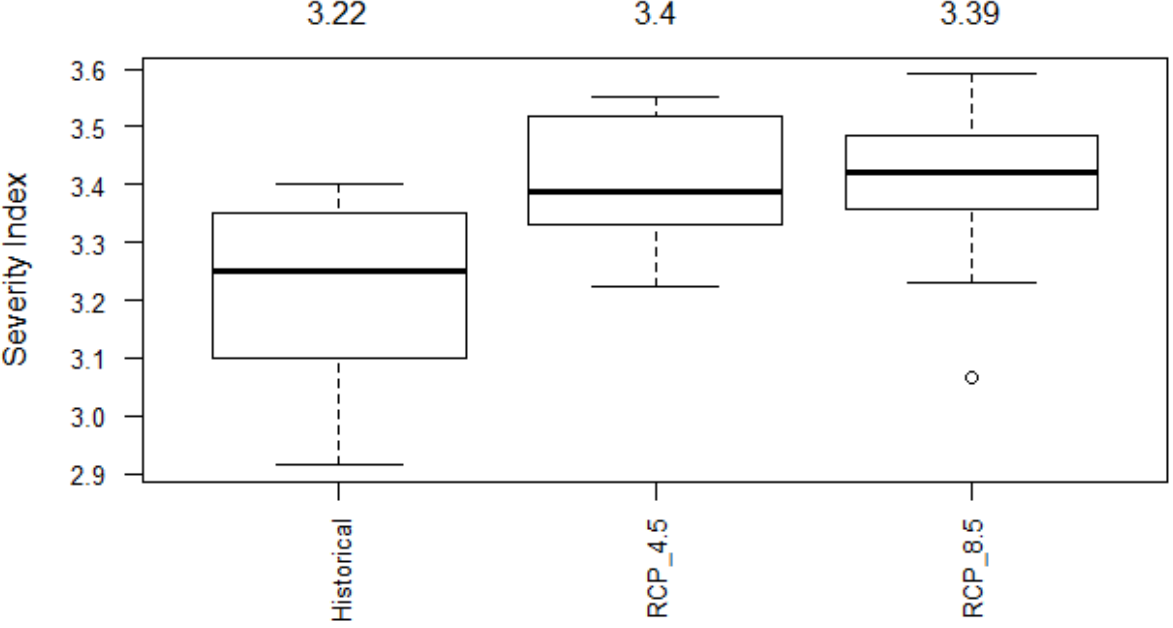

b

Mean Fire Severity

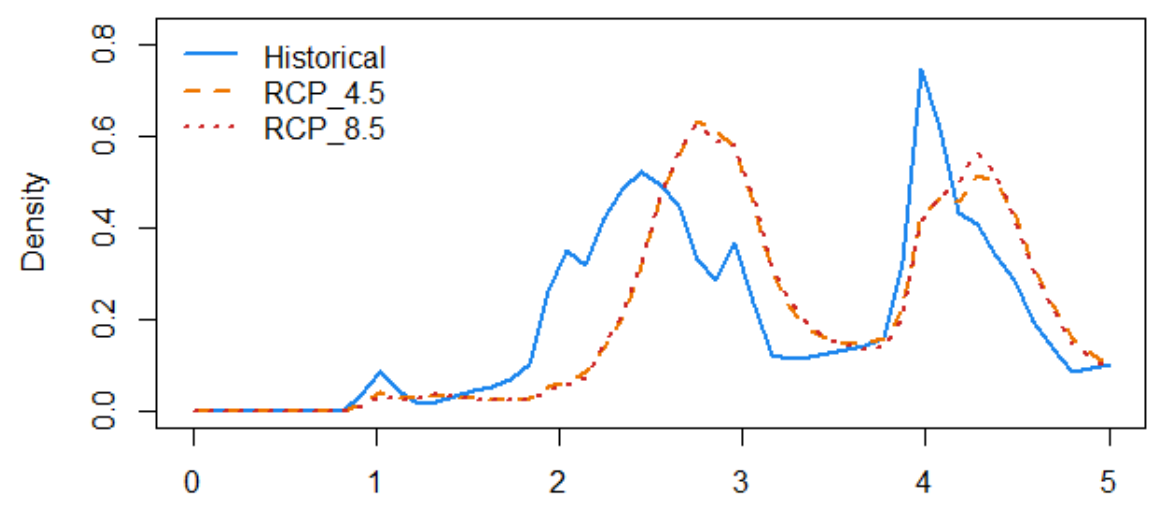

Fire Severity Index

Figure 2.15. Mean fire severity under contemporary weather and climate change projections averaged across 10 replicates for each scenario. Fire severity was significantly higher for climate change scenarios than Contemporary $(p=0.02)$, but there was no difference between RCP 4.5 and RCP 8.5 scenarios $(p=0.98)$. In the boxplot $(a$.$) , boxes encompass the 25^{\text {th }}$ and $75^{\text {th }}$ percentiles and the solid line represents the median. Whiskers extend to $1.5 x$ the inner quartile range. The density plot (b.) shows the shift in distribution of fire severities under climate change, which have a greater proportion of fire severities in the range of $2.5-3.5$ and greater than 4.2 than under contemporary weather. 


\section{Mean Fire Severity}

Historical

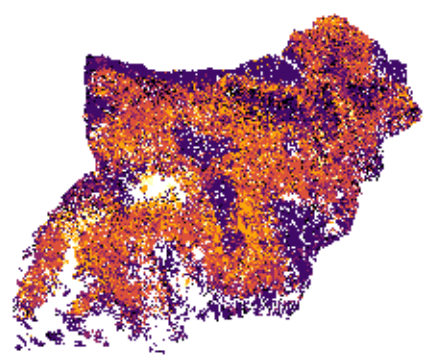

RCP_4.5

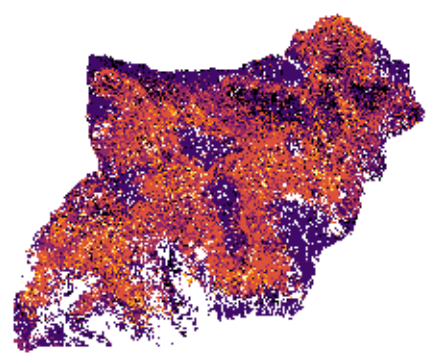

RCP_8.5

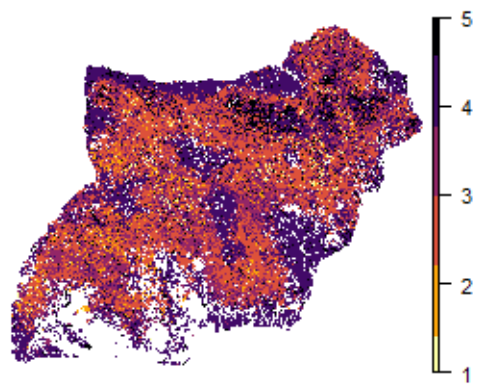

Figure 2.16. Maps of mean fire severity averaged across all replicates and all years for each climate scenario. Mean fire severity was higher under climate change, and the highest severity fires occurred in the northeastern portion of the landscape. The highest mean severity was in forest dominated by high-elevation species (e.g., sub-alpine fir, whitebark pine, Engelmann spruce). Shrublands and grasslands also burned at high severity, reflecting the high potential mortality of shrub and grass species.

Table 2.4. Wildfire metric results. Mean severity is averaged across all years. Annual area burned is reported for all years and for the last 30 years. Standard deviation is in parentheses.

\begin{tabular}{|c|c|c|c|}
\hline & Historical & RCP 4.5 & RCP 8.5 \\
\hline Mean Severity & $3.22(0.16)$ & $3.40(0.11)$ & $3.39(0.15)$ \\
\hline $\begin{array}{l}\text { Mean Annual Area } \\
\text { Burned (All Years) }\end{array}$ & 6,272 ha $(20,152)$ & 9,970 ha $(36,312.62)$ & 10,876 ha $(37,849)$ \\
\hline $\begin{array}{l}\text { Mean Annual Area } \\
\text { Burned (Last } 30 \\
\text { Years) }\end{array}$ & 4,663 ha $(13,724)$ & 7,249 ha $(26,371)$ & 9,633 ha $(33,433)$ \\
\hline $\begin{array}{l}\text { Fire Rotation } \\
\text { Period }\end{array}$ & 150 years & 94 years & 86 years \\
\hline
\end{tabular}

\subsubsection{Forest dynamics}

Aboveground biomass increased over time under all scenarios (Contemporary $+23.3 \%, \mathrm{RCP} 4.5+23.7 \%$, RCP $8.5+23.5 \%)$, and there was no difference in the change in total biomass among scenarios $(F=0.016, p=0.98$; Figure 17). However, biomass density and spatial distribution differed among species and among contemporary and climate change scenarios (see Table 5). The four most common species on the landscape 
- ponderosa pine, grand fir, Douglas fir and western juniper - all increased in landscapelevel average biomass over time under all scenarios except western juniper, which increased under contemporary weather but maintained or lost biomass under climate change. The biomass of less common high-elevation species, including sub-alpine fir, Engelmann spruce, and whitebark pine, declined under all scenarios, while lodgepole pine and western larch gained biomass under contemporary weather but declined under climate change. 

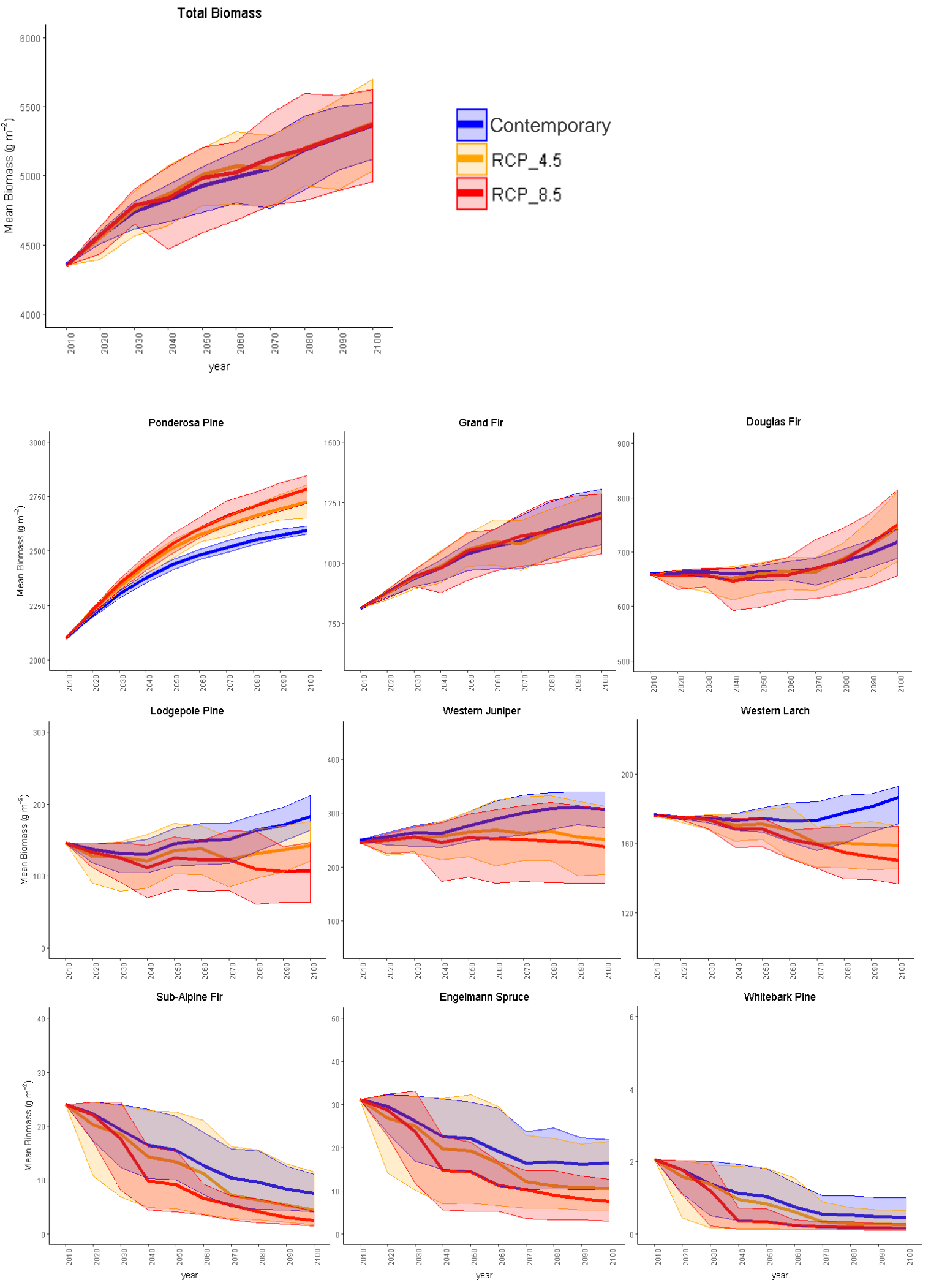
Figure 2.17. Average total biomass and biomass of individual species through time for each climate scenario. Biomass is averaged across all 4-ha sites on the landscape, including sites where a given species does not occur, in order to reflect both changes in biomass density and extent among species at the landscape level. Aboveground biomass increased under all scenarios, which was driven by increasing ponderosa pine, grand fir and Douglas fir biomass and extent. Lodgepole pine, western juniper and western larch increased under contemporary weather but declined under climate change, and high-elevation species (sub-alpine fir, Engelmann spruce, and whitebark pine) declined under all scenarios.

Landscape-level biomass change was influenced by two factors: density of species in sites where they occur (Figure 2.18, Table 2.5) and extent across the landscape. Ponderosa pine responded favorably to climate change and increased in both biomass density and extent with the greatest increases in both under climate change. Grand fir increased in density under climate change and extent under all scenarios, although its range did not increase as much under climate change as under contemporary weather. Douglas fir's overall increase in biomass was due to an increase in extent, which was greatest under contemporary weather, however, site-level density declined under all scenarios. Conversely, western juniper's density increased over time while experiencing range contraction under all scenarios, indicating that while some juniper stands were removed by senescence and wildfire that allowed ponderosa pine to establish, growth and reproduction in the stands that remained outpaced mortality. 
Average \% Change in Biomass Density Where Species Present

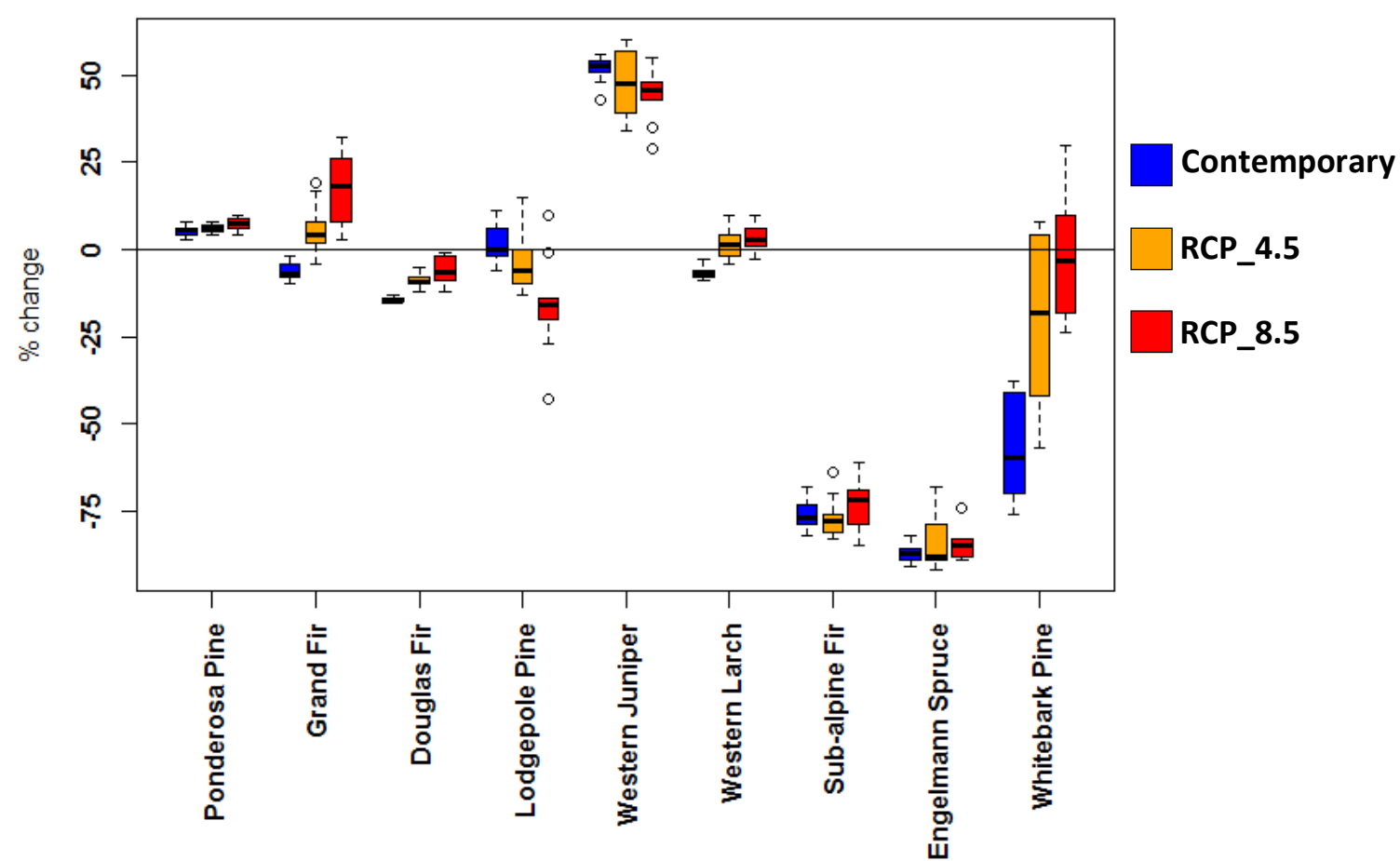

Figure 2.18. Average percent change in biomass density. Boxplots show the percent of simulated biomass change from 2010 to 2100 for all modeled conifer species averaged across sites where each species occurs. The horizontal line indicates no change in density over the 90 -year simulation period. Ponderosa pine and western juniper density increased under all scenarios. Grand fir and western larch density decreased under contemporary weather, changed little under moderate climate change, and increased under RCP 8.5. Douglas fir density decreased under all scenarios, while lodgepole pine density varied among replicates. Sub-alpine fir, Engelmann spruce, and whitebark pine density declined under all climate scenarios, although whitebark pine was the most variable with increases in density of up to $30 \%$ and decreases of up to $24 \%$ under individual RCP 8.5 replicates.

Two species, western larch and lodgepole pine, did not experience large changes in either density or extent regardless of climate scenario. Western larch, which currently occurs on about $14 \%$ of the landscape, decreased slightly in extent (to 11-12\%) but increased slightly in density (by 1-3\%). Lodgepole pine density remained steady under contemporary and moderate climate change conditions ( $-4 \%$ to $+1 \%)$, and extent 
changed by only $2-3 \%$, increasing under contemporary climate and either staying the same or decreasing under climate change.

High-elevation species, including Engelmann spruce, sub-alpine fir, and whitebark pine, declined under all scenarios with the greatest declines under RCP 8.5. Over the 90-year period, sub-alpine fir and Engelmann spruce density declined by more than $75 \%$. However, under contemporary weather and moderately hotter/drier conditions, their range expanded slightly, indicating that even though existing stands were being replaced by other species or converted to non-forest following senescence and disturbance, seed dispersal and reproduction were still occurring. Under the hottest and driest conditions, however, extent declined. Whitebark pine, which currently inhabits sparse stands on only a small portion of the landscape $(0.4 \%)$, declined in both density and extent under all scenarios. Density in stands where it persisted decreased the least under climate change, but its range contracted to $0.03 \%-0.07 \%$, virtually disappearing from the landscape.

Table 2.5. Biomass density and extent values for all conifer tree species. Individual species biomass is averaged only in sites where that species occurs. Increases in density and extent over time are in white; decreases are in gray. Climate change scenarios are shortened to CC Moderate (RCP 4.5 emissions scenario) and CC - High (RCP 8.5 emissions scenario). Standard deviations are given in parentheses.

\begin{tabular}{|l|l|l|l|l|l|l|}
\hline \multirow{2}{*}{$\begin{array}{l}\text { Species } \\
\text { Scenario }\end{array}$} & \multicolumn{3}{|l|}{ Biomass $\left(\mathbf{g ~ m}^{-2}\right)$} & \multicolumn{2}{l|}{$\begin{array}{l}\text { Extent (\% of } \\
\text { landscape) }\end{array}$} \\
\hline & & Start & End & $\%$ Change & Start \% & End \% \\
\hline $\begin{array}{l}\text { Pinus } \\
\text { ponderosa }\end{array}$ & Contemporary & 3628 & $\begin{array}{l}3814 \\
(60)\end{array}$ & $\begin{array}{l}+5.1 \% \\
(1.6 \%)\end{array}$ & $57.9 \%$ & $\begin{array}{l}68.0 \% \\
(1.0 \%)\end{array}$ \\
\cline { 2 - 7 } $\begin{array}{l}\text { Ponderosa } \\
\text { pine }\end{array}$ & CC - Moderate & 3628 & $\begin{array}{l}3841 \\
(37)\end{array}$ & $\begin{array}{l}+5.9 \% \\
(1.0 \%)\end{array}$ & $57.9 \%$ & $\begin{array}{l}70.9 \% \\
(1.5 \%)\end{array}$ \\
\hline
\end{tabular}




\begin{tabular}{|c|c|c|c|c|c|c|}
\hline & CC - High & 3628 & $\begin{array}{l}3890 \\
(74)\end{array}$ & $\begin{array}{l}+7.8 \% \\
(2.0 \%)\end{array}$ & $57.9 \%$ & $\begin{array}{l}71.6 \% \\
(1.1 \%)\end{array}$ \\
\hline \multirow{3}{*}{$\begin{array}{l}\text { Abies grandis } \\
\text { Grand fir }\end{array}$} & Contemporary & 2977 & $\begin{array}{l}2791 \\
(78)\end{array}$ & $\begin{array}{l}-6.2 \% \\
(2.6 \%)\end{array}$ & $27.2 \%$ & $\begin{array}{l}43.3 \% \\
(2.6 \%)\end{array}$ \\
\hline & CC - Moderate & 2977 & $\begin{array}{l}3160 \\
(210)\end{array}$ & $\begin{array}{l}+6.1 \% \\
(7.0 \%)\end{array}$ & $27.2 \%$ & $\begin{array}{l}37.9 \% \\
(2.6 \%)\end{array}$ \\
\hline & CC - High & 2977 & $\begin{array}{l}3504 \\
(294)\end{array}$ & $\begin{array}{l}+17.7 \% \\
(9.9 \%)\end{array}$ & $27.2 \%$ & $\begin{array}{l}34.0 \% \\
(3.5 \%)\end{array}$ \\
\hline \multirow{3}{*}{$\begin{array}{l}\text { Pseudotsuga } \\
\text { menziesii } \\
\text { Douglas fir }\end{array}$} & Contemporary & 1831 & $\begin{array}{l}1564 \\
(13)\end{array}$ & $\begin{array}{l}-14.6 \% \\
(0.7 \%)\end{array}$ & $36.0 \%$ & $\begin{array}{l}46.0 \% \\
(1.2 \%)\end{array}$ \\
\hline & CC - Moderate & 1831 & $\begin{array}{l}1666 \\
(39)\end{array}$ & $\begin{array}{l}-9.0 \% \\
(2.15 \%)\end{array}$ & $36.0 \%$ & $\begin{array}{l}44.6 \% \\
(1.8 \%)\end{array}$ \\
\hline & CC - High & 1831 & $\begin{array}{l}1720 \\
(66)\end{array}$ & $\begin{array}{l}-6.0 \% \\
(3.6 \%)\end{array}$ & $36.0 \%$ & $\begin{array}{l}43.6 \% \\
(2.2 \%)\end{array}$ \\
\hline \multirow{3}{*}{$\begin{array}{l}\text { Pinus } \\
\text { contorta } \\
\text { Lodgepole } \\
\text { pine }\end{array}$} & Contemporary & 1160 & $\begin{array}{l}1176 \\
(61)\end{array}$ & $\begin{array}{l}+1.3 \% \\
(5.3 \%)\end{array}$ & $12.5 \%$ & $\begin{array}{l}15.5 \% \\
(0.9 \%)\end{array}$ \\
\hline & CC - Moderate & 1160 & $\begin{array}{l}1112 \\
(98)\end{array}$ & $\begin{array}{l}-4.1 \% \\
(8.4 \%)\end{array}$ & $12.5 \%$ & $\begin{array}{l}12.8 \% \\
(1.2 \%)\end{array}$ \\
\hline & CC - High & 1160 & $\begin{array}{l}979 \\
(163)\end{array}$ & $\begin{array}{l}-15.6 \% \\
(14.1 \%)\end{array}$ & $12.5 \%$ & $\begin{array}{l}10.8 \% \\
(1.6 \%)\end{array}$ \\
\hline \multirow{3}{*}{$\begin{array}{l}\text { Juniperus } \\
\text { occidentalis } \\
\text { Western } \\
\text { juniper }\end{array}$} & Contemporary & 555 & $\begin{array}{l}856 \\
(23)\end{array}$ & $\begin{array}{l}+54.2 \% \\
(4.1 \%)\end{array}$ & $42.2 \%$ & $\begin{array}{l}35.9 \% \\
(2.1 \%)\end{array}$ \\
\hline & CC - Moderate & 555 & $\begin{array}{l}819 \\
(55)\end{array}$ & $\begin{array}{l}+47.6 \% \\
(9.8 \%)\end{array}$ & $42.2 \%$ & $\begin{array}{l}30.5 \% \\
(4.3 \%)\end{array}$ \\
\hline & CC - High & 555 & $\begin{array}{l}803 \\
(45)\end{array}$ & $\begin{array}{l}+44.8 \% \\
(7.9 \%)\end{array}$ & $42.2 \%$ & $\begin{array}{l}29.3 \% \\
(4.9 \%)\end{array}$ \\
\hline \multirow{3}{*}{$\begin{array}{l}\text { Larix } \\
\text { occidentalis } \\
\text { Western larch }\end{array}$} & Contemporary & 1282 & $\begin{array}{l}1201 \\
(26)\end{array}$ & $\begin{array}{l}-6.4 \% \\
(2.0 \%)\end{array}$ & $13.76 \%$ & $\begin{array}{l}15.5 \% \\
(0.5 \%)\end{array}$ \\
\hline & CC - Moderate & 1282 & $\begin{array}{l}1299 \\
(54)\end{array}$ & $\begin{array}{l}+1.3 \% \\
(4.2 \%)\end{array}$ & $13.76 \%$ & $\begin{array}{l}12.2 \% \\
(0.8 \%)\end{array}$ \\
\hline & CC - High & 1282 & $\begin{array}{l}1323 \\
(47)\end{array}$ & $\begin{array}{l}+3.2 \% \\
(3.6 \%)\end{array}$ & $13.76 \%$ & $\begin{array}{l}11.36 \% \\
(0.9 \%)\end{array}$ \\
\hline $\begin{array}{l}\text { Abies } \\
\text { lasiocarpa }\end{array}$ & Contemporary & 1265 & $\begin{array}{l}161 \\
(36)\end{array}$ & $\begin{array}{l}-87.2 \% \\
(2.9 \%)\end{array}$ & $1.9 \%$ & $\begin{array}{l}4.6 \% \\
(1.0 \%)\end{array}$ \\
\hline
\end{tabular}




\begin{tabular}{|c|c|c|c|c|c|c|}
\hline \multirow[t]{2}{*}{ Sub-alpine fir } & CC - Moderate & 1265 & $\begin{array}{l}201 \\
(103)\end{array}$ & $\begin{array}{l}-84.1 \% \\
(8.12 \%)\end{array}$ & $1.9 \%$ & $\begin{array}{l}2.0 \% \\
(0.9 \%)\end{array}$ \\
\hline & CC - High & 1265 & $\begin{array}{l}208 \\
(70)\end{array}$ & $\begin{array}{l}-84.0 \% \\
(5.5 \%)\end{array}$ & $1.9 \%$ & $\begin{array}{l}1.2 \% \\
(0.5 \%)\end{array}$ \\
\hline \multirow{3}{*}{$\begin{array}{l}\text { Picea } \\
\text { engelmannii } \\
\text { Engelmann } \\
\text { spruce }\end{array}$} & Contemporary & 1387 & $\begin{array}{l}328 \\
(59)\end{array}$ & $\begin{array}{l}-76.3 \% \\
(4.2 \%)\end{array}$ & $2.2 \%$ & $\begin{array}{l}5.0 \% \\
(1.3 \%)\end{array}$ \\
\hline & CC - Moderate & 1387 & $\begin{array}{l}324 \\
(83)\end{array}$ & $\begin{array}{l}-76.6 \% \\
(6.0 \%)\end{array}$ & $2.2 \%$ & $\begin{array}{l}3.2 \% \\
(1.2 \%)\end{array}$ \\
\hline & CC - High & 1387 & $\begin{array}{l}364 \\
(102)\end{array}$ & $\begin{array}{l}-74.8 \% \\
(7.3 \%)\end{array}$ & $2.2 \%$ & $\begin{array}{l}2.1 \% \\
(1.0 \%)\end{array}$ \\
\hline \multirow{3}{*}{$\begin{array}{l}\text { Pinus } \\
\text { albicaulis } \\
\text { Whitebark } \\
\text { pine }\end{array}$} & Contemporary & 541 & $\begin{array}{l}229 \\
(81)\end{array}$ & $\begin{array}{l}-57.7 \% \\
(14.9 \%)\end{array}$ & $0.40 \%$ & $\begin{array}{l}0.23 \% \\
(0.2 \%)\end{array}$ \\
\hline & CC - Moderate & 541 & $\begin{array}{l}429 \\
(145)\end{array}$ & $\begin{array}{l}-20.8 \% \\
(26.8 \%)\end{array}$ & $0.40 \%$ & $\begin{array}{l}0.07 \% \\
(0.08 \%)\end{array}$ \\
\hline & CC - High & 541 & $\begin{array}{l}535 \\
(95)\end{array}$ & $\begin{array}{l}-1.2 \% \\
(17.5 \%)\end{array}$ & $0.40 \%$ & $\begin{array}{l}0.03 \% \\
(0.02 \%)\end{array}$ \\
\hline
\end{tabular}

The degree to which climate conditions facilitated establishment of individual species, both within sites and by dispersing to neighboring sites, was measured through probability of establishment, an internal calculation within the NECN succession extension (Figure 2.19). Probability is based on growing degree days, drought tolerance, and minimum January temperatures. For each of the high-elevation species, the probability of establishment under climate change fell throughout the century. Western larch, which lost biomass under climate change reflecting its preference for moister, shadier locations, also saw establishment decline under climate change. In contrast, drymixed conifer species that increased in overall biomass, including ponderosa pine and Douglas fir, maintained high probability of establishment throughout the century with the RCP 8.5 scenario providing the most favorable conditions for establishment. 
Western juniper also maintained a high probability of establishment under all climate scenarios, which allowed density to increase within sites through regeneration. While grand fir's probability of establishment fell to around 0.1 under the RCP 8.5 scenario, about one third of that of ponderosa pine, it still expanded in extent over time. 


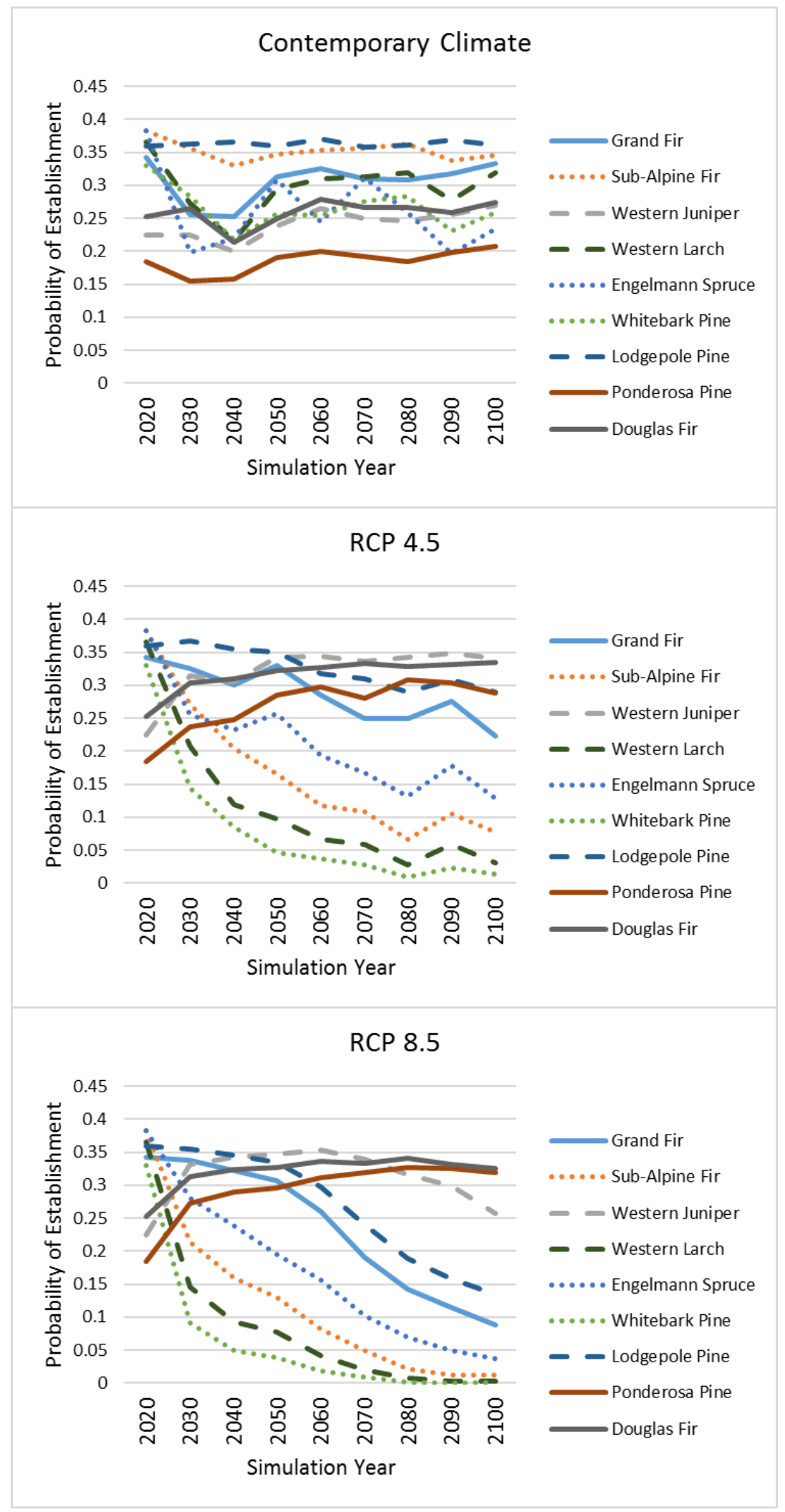

Figure 2.19. Probability of establishment of conifer species under each climate scenario. Species 
that generally increased biomass over time are in solid lines. Species that generally maintained biomass over time are in dashed lines. Species that lost biomass over time are in dotted lines.

\subsubsection{Abiotic factors and biomass}

After accounting for climate scenario as a blocking term in the PERMANOVA model, the most influential abiotic factors in biomass change were the number of times a cell burned over the 90-year simulation period, elevation, and slope as well as the interactions among these three variables (Table 2.6). Between them, they account for $26.8 \%$ of the variation in community biomass change. Within-scenario differences in temperature were not a significant driver of changes in biomass $\left(R^{2}=0.004, p=1.0\right)$. While precipitation did affect biomass change, it was significantly correlated with scenario $(r=-0.64)$, and the within-scenario differences in precipitation explained only an additional $2 \%$ of variation. Soil type explained very little ( $0.7 \%$ of variation), and was removed from the model. The final PERMANOVA model was Biomass Change Burns*Elevation*Slope.

Table 2.6. Results from permutational multivariate analysis of variance (PERMANOVA). In the full model, only the most influential interaction terms are reported.

\begin{tabular}{|llllll|} 
& $\begin{array}{l}\text { Degrees of } \\
\text { Freedom }\end{array}$ & $\begin{array}{l}\text { Sum of } \\
\text { Squares }\end{array}$ & F Model & $\mathbf{R}^{\mathbf{2}}$ & P-value \\
& $\begin{array}{l}\text { Full Model: } \\
\text { Burns*Elevation*Slope in Biomass } ~\end{array}$ Number of \\
& 1 & 0.3895 & 248.372 & 0.06587 & $0.001^{*}$ \\
\hline Number of Burns & 1 & 0.2801 & 178.618 & 0.04737 & $0.001^{*}$ \\
\hline Elevation & 1 & 0.1217 & 77.618 & 0.02058 & $0.001^{*}$ \\
\hline Slope & 1 & 0.0938 & 59.836 & 0.01587 & $0.001^{*}$ \\
\hline Precipitation & 1 & 0.0255 & 16.235 & 0.00431 & 1.000 \\
\hline Temperature & 1 & 0.0435 & 27.750 & 0.00736 & $0.001^{*}$ \\
\hline Soil Type & 1 & 0.1838 & 117.222 & 0.03109 & $0.001^{*}$ \\
\hline Burns:Elevation & 1 & & & & \\
\hline
\end{tabular}




\begin{tabular}{|llllll|}
\hline Burns:Slope & 1 & 0.2186 & 139.414 & 0.03697 & $0.001^{*}$ \\
\hline Elevation:Slope & 1 & 0.0734 & 46.819 & 0.01242 & $0.001^{*}$ \\
\hline Burns:Elevation:Slope & 1 & 0.2345 & 149.531 & 0.03966 & $0.001^{*}$ \\
\hline & \multicolumn{7}{l}{$\begin{array}{l}\text { Best Model: } \\
\text { Burns*Elevation*Slope }\end{array}$} & & \\
\hline Number of Burns & 1 & 0.4052 & 206.463 & 0.06869 & $0.001^{*}$ \\
\hline Elevation & 1 & 0.3534 & 180.050 & 0.05990 & $0.001^{*}$ \\
\hline Slope & 1 & 0.0720 & 36.691 & 0.01221 & $0.001^{*}$ \\
\hline Burns:Elevation & 1 & 0.4342 & 221.217 & 0.07359 & $0.001^{*}$ \\
\hline Burns:Slope & 1 & 0.714 & 36.356 & 0.01209 & $0.001^{*}$ \\
\hline Elevation:Slope & 1 & 0.1201 & 61.193 & 0.02036 & $0.001^{*}$ \\
\hline Burns:Elevation:Slope & 1 & 0.1235 & 61.193 & 0.02036 & $0.001^{*}$ \\
\hline Residuals & 2201 & 4.3200 & & 0.73223 & \\
\hline Total & 2208 & 5.8998 & & 1.0 & \\
\hline
\end{tabular}

\subsection{Discussion}

Average temperatures in the northwestern United States have risen by about 1 degree Celsius in the last century, and an additional increase of $1.8-5.4$ degrees $C$ is expected by the end of the century (USGCRP et al. 2014). Projected changes in precipitation range across GCMs from around $-11 \%$ to $+18 \%$, but climate models consistently project decreases in summer precipitation and a greater proportion of winter precipitation falling as rain instead of snow, leading to lower snowpack, earlier snowmelt, and reduced streamflow (Hamlet et al. 2007, Mote and Salathé 2010, USGCRP et al. 2014). This study's findings of increases in simulated fire frequency, annual area burned, and severity reflect the Southern Blue Mountain region's vulnerability to these changes in climatic drivers of fire. To capture the uncertainty around temperature and precipitation shifts projected by various GCMs, I used a range of conditions encompassing the most and least extreme scenarios in simulations. The 
consistent pattern of increased fire activity under this range of climate conditions is clear, although the differences among moderate and high emissions climate scenarios were not significant. This serves to underscore an important point: fire activity accelerates under a wide range of projected conditions. Therefore, uncertainty around the amplitude of temperature and precipitation changes should not be a reason to stall decision-making around forest management.

In order to observe the influence of dynamic changes in forest composition linked both to climate mediators of growth and reproduction and to mortality from wildfire, I held management constant across simulations. Changes in forest composition altered fuel beds over time, which led to a feedback in subsequent wildfire activity. The temporal pattern of area burned is evidence of this interaction. Area burned was generally stable over time under contemporary weather conditions, while under climate change, annual area burned increased for the first fifty-five years but declined during the subsequent half of the century. In contrast, total biomass increased steadily over the entire century under all climate scenarios, but forest composition, and therefore fuel beds, shifted through species-specific changes in biomass density and extent. Highelevation, fire-sensitive species that typically experience high mortality during wildfire, including sub-alpine fir and Engelmann spruce, declined during the second half of the century, coincident with a trend of declining area burned. Whitebark pine, an earlysuccessional conifer found at high elevations, maintained higher density relative to subalpine fir and Engelmann spruce under climate change, which is consistent with its 
higher drought tolerance and advantageous regeneration strategy following wildfire (Sala et al. 2001). However, whitebark pine has already been largely replaced by these later-successional species following decades of fire suppression, as it relies on seed caching in fire-opened patches by Clark's nutcracker. Its loss in extent over all scenarios reflects this legacy of a lack of seed source (Lillybridge et al. 1995). In addition, the larger, more severe fires under climate change do not emulate the infrequent standreplacement fires and the patches of high-severity within larger mixed-severity fires that historically supported whitebark pine establishment and the low to moderate severity fires that reduced competition from co-occurring species (Perkins et al. 2016).

These patterns in biomass shifts occurred under all climate scenarios, however, there is more uncertainty and a potential for shifts of greater magnitude under hotter and drier climate conditions (Figure 2.20). As shown in Figure 2.21, biomass reductions were greatest in high-elevation sites, which is consistent with state-and-transition modeling studies that projected losses in sub-alpine forests in eastern Oregon under a range of climate change models (Halofsky et al. 2013). Species distribution research (Mathys et al. 2017) also found range constriction and increased stress under climate change for whitebark pine, sub-alpine fir, and lodgepole pine. While the latter study did not account for wildfire, they found that lodgepole pine distribution is limited by both high summer temperatures and soil water deficit from insufficient snowmelt, which is consistent with this study's finding of reduced biomass density and extent under climate change. In some ecosystems, the increase in high-severity wildfire under climate change 
could lead to successful post-fire lodgepole pine regeneration from seed stored in serotinous cones (Anderson 2003), however, most lodgepole pines in the study area produce non-serotinous cones (Crowe and Clausnitzer 1997) and do not gain a competitive edge from the increase of wildfire activity.

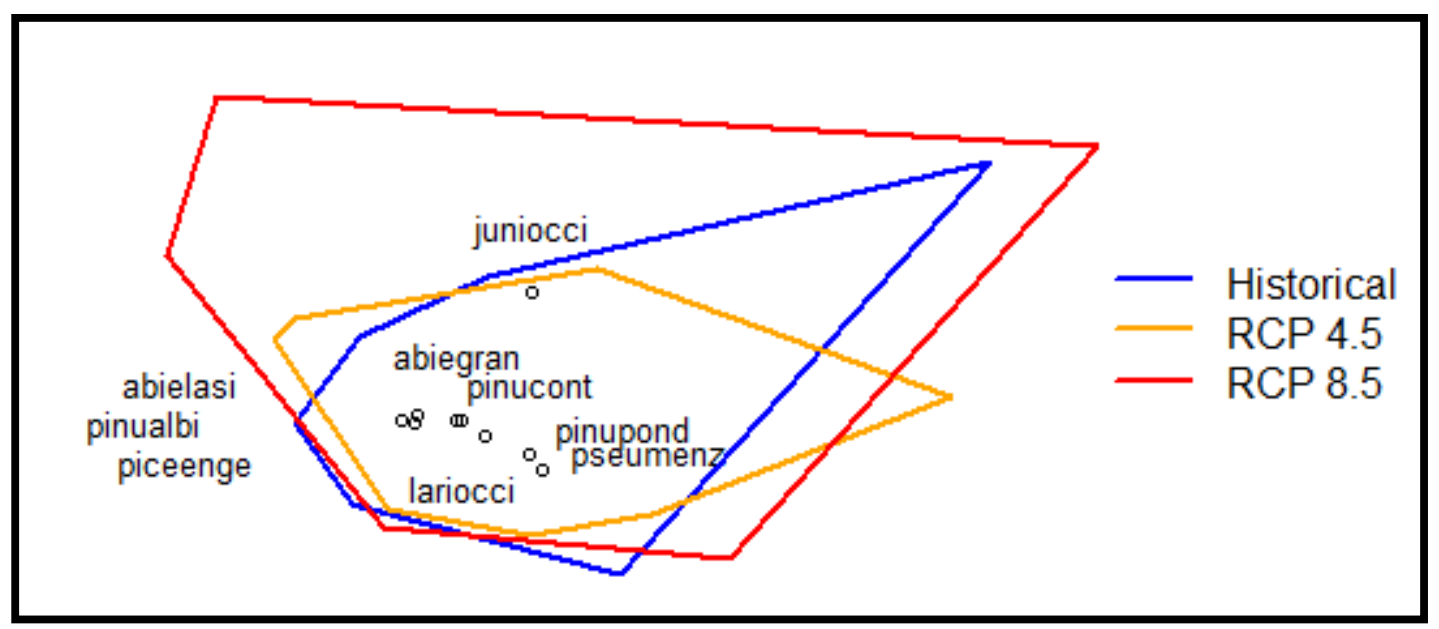

Figure 2.20. Non-metric multi-dimensional scaling (NMDS) ordination of change in biomass for the nine conifer species by weighted species scores. Species closer together in ordination space tended to gain or lose biomass similarly over time. Hulls enclose the extent of sites in ordination space for each climate scenario. Under all scenarios, biomass was gained or lost similarly, but there was greater variability under the RCP 8.5 emissions scenario. Axes are dimensionless. (abielasi $=$ grand fir, pinualbi $=$ whitebark pine, piceenge $=$ Engelmann spruce, juniocci $=$ western juniper, abiegran $=$ grand fir , pinucont $=$ lodgepole pine, pinupond $=$ ponderosa pine, pseumenz $=$ douglas fir, lariocci = western larch). 


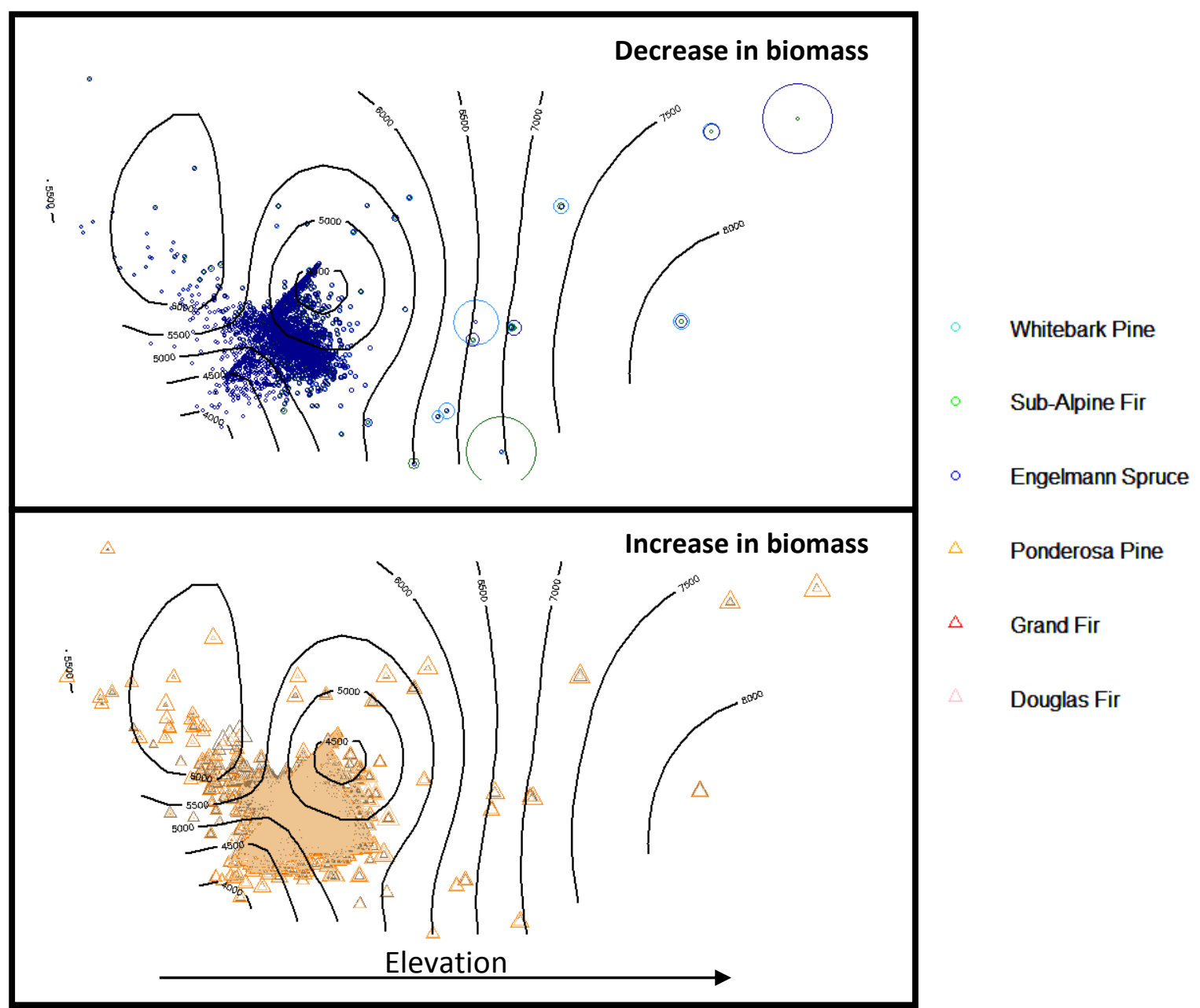

Figure 2.21. Non-metric multi-dimensional scaling (NMDS) ordination of change in biomass of six tree species across the elevational gradient. Sites with similar biomass change across species are clumped closer together while sites that differ in their degree of biomass change are further apart. Axes are dimensionless. Elevation increases from left to right, and lower-elevation sites tended to be more similar to each other than to high-elevation sites. The top plot shows highelevation species (whitebark pine, sub-alpine fir, and Engelmann spruce), which declined the most at high elevations, coincident with high repeat numbers of burns. The size of each point is scaled by the degree of biomass decline. The bottom plot shows expansion of biomass for the species that increased in biomass across all scenarios (ponderosa pine, grand fir, and Douglas fir), and the size of each point is scaled by the degree of biomass increase. These species increased at a fairly equal rate across the landscape regardless of elevation. 
Increases in biomass and extent of ponderosa pine and Douglas fir are also consistent with previous research. Halofsky et al. (2013) found that temperate needle leaf forest (ponderosa pine, lodgepole pine, and dry mixed conifer forests including Douglas fir and grand fir) either maintained or increased extent under climate change scenarios, while Mathys et al. (2017) found that Douglas fir and ponderosa pine may benefit from climate change in some locations. Increased ponderosa pine dominance has also been projected on the order of $5-10 \%$ in inland Oregon based on physiological modeling (Coops et al. 2005) with the conclusion that lower snowpack in the sub-alpine zone may lead to range expansion into higher elevations. Additionally, ponderosa pine's resistance to wildfire and legacy of dominance on the study landscape give it a competitive advantage both in persistence and regeneration.

The mechanisms behind increases in grand fir density and extent under climate change are less clear. Grand fir's probability of establishment declines under climate change and its susceptibility to fire is higher than either ponderosa pine or Douglas fir, yet biomass increases under all scenarios with regeneration making up 3-25\% of total simulated grand fir biomass under the highest emissions scenario. While grand fir is generally found in moist sites, it is also the most drought-tolerant fir in the Pacific Northwest (Howard and Aleksoff 2000) and can establish and survive on a range of sites from warm and moderately dry to moist (Lillybridge et al. 1995). It is moderately fire resistant once it reaches maturity (Howard and Aleksoff 2000) but generally only dominates in areas where fire has been excluded, because grand fir regeneration and 
young cohorts create high fuel loadings that result in high mortality from fire (Habeck and Mutch 1973). The shift from fire-susceptible to fire-resistant species in higher elevations could facilitate this expansion of grand fir by moving toward a lower severity fire regime associated with ponderosa pine-dominated forests over time. However, it is also possible that there is an overestimation of grand fir regeneration or an underestimation of mortality that may influence simulated grand fir biomass shifts over time.

These shifts in species composition characterize a decline in rare species on the landscape and forest homogenization at high elevations. This biomass change was experienced most in areas that were burned repeatedly and especially at high elevation and on steep slopes. While increases in ponderosa pine may lead to an increased landscape-level resilience, or ability to remain in the same state following wildfire (Carpenter et al. 2001), a reduction in heterogeneity of species composition on the landscape has other far-reaching effects, both ecologically and socially. Biodiverse landscapes are more resilient to disturbance through providing functional redundancy (Oliver et al. 2015), varying the effects of individual disturbances from patch to patch as well as providing variable responses to different disturbances (e.g., windthrow, insect infestations, disease; Folke et al. 2004). They also provide a variety of wildlife habitat, natural resource, and recreation environments that produce a broad range of ecosystem services. It is up to land managers and local communities to consider 
whether it is of high priority for them to intervene to slow the inevitable conversion of cool mixed-conifer forest at high elevations to ponderosa-pine dominated forest.

\subsubsection{Limitations}

This study employed a dynamic forest landscape model, which was carefully parameterized and calibrated. As with any study that employs modeling, there are limitations and uncertainty associated with the model. The number of ecological processes that can be included are limited by the model itself and by time limitations. In this case, I employed model extensions to simulate forest succession (seed dispersal, reproduction, growth, competition, age-related mortality), harvest (mechanical tree removal and prescribed fire), and wildfire. I did not include wind disturbance or insect damage, but I included estimated mortality associated with these disturbances by calibrating the model's simulated background mortality with empirical data and expert consultation (M. Jennings, personal communication, February 14, 2017). Uncertainty is also introduced through the parameterization of the model; for instance, vegetation, temperature, precipitation, and soil characteristics are derived from point sources that have been imputed to a 4-ha resolution, thereby introducing error. However, a study at this scale (approximately 1 million ha) attempts to identify broad spatial and temporal trends and approximations from site-level data are sufficient for this purpose.

Stochasticity in modeled disturbance can also introduce uncertainty as interactions between forest succession and disturbance can lead to a range of outcomes 
over the simulation period. To minimize this uncertainty, I have run 10 replicates of every scenario and reported mean values across replicates.

\subsection{Conclusions}

GCMs consistently project hotter temperatures, a greater proportion of precipitation falling as rain rather than snow, earlier snowmelt, and longer fire seasons in the western U.S. (Scholze et al. 2006, Littell et al. 2009). This study, which looked at the effects of those changes on wildfire activity and forest dynamics in the intermountain west, found that even with uncertainty about the magnitude of future climatic trends, wildfire extent and severity will be more extreme than what this landscape has experienced in the recent past. Changes in forest composition will be driven by changes in the fire regime with feedbacks through modification of fuel beds. The greatest impacts of climate change on this landscape occur at high elevations where sensitive species will be replaced by migration of tree species typically found at lower elevations following wildfire and due to limitations to establishment under drier conditions. These findings underscore the critical need for forest managers to actively consider climate change, shifting fire regimes, and social and ecological priorities around managing for rare species in their long-term management plans. 
Chapter 3 - Optimizing placement of fuel treatments and accelerating prescribed fire ameliorates extreme weather-driven wildfires in western mixed-conifer forests

\subsection{Introduction and background}

Wildfire in the western United States is burning more area annually than previously recorded in the modern period (Westerling et al. 2006a, Littell et al. 2009). Increased temperatures and greater variability in precipitation resulting from climate change are leading to longer fire seasons with fire-conducive weather and low fuel moisture. This has led to a greater number of wildfires that escape suppression efforts, and this trend is projected to continue (Whitlock 2003, Westerling et al. 2006a, Fried et al. 2008). Land management agencies are tasked with the protection of resources from wildfire, which they balance with multiple objectives such as preserving wildlife habitat, facilitating recreation, and economic concerns. Agencies such as the USDA Forest Service (USFS) want to accelerate the pace of restoration to both increase the resiliency of forests to disturbance and provide jobs in rural communities (USDA Forest Service 2012). Forest and landscape restoration is often used to achieve multiple objectives while modifying forest stand structure to better resist fires by reducing fuel beds and providing fuel breaks. However, the cost of fire suppression has more than quadrupled over the past 30 years, with federal spending topping \$2 billion in 2015 (NIFC 2016) and expending $50 \%$ of agency budgets (North et al. 2015), which has led to an imbalance in available funds for preventative fire management. Given financial constraints, it is 
critical that preventative forest management actions, specifically fuel treatments, be planned and implemented efficiently and effectively.

Previous studies have shown that fuel treatments in dry mixed-conifer forests are effective in reducing wildfire severity when wildfires intersect existing treatments (Prichard et al. 2010, Johnson et al. 2011, Syphard et al. 2011a, Safford et al. 2012), and that combining mechanical thinning with prescribed burning can be more effective than each treatment type alone (Schwilk et al. 2009). Studies that used modeling to understand fuel treatment effectiveness have also projected improved fire resistance in forests that are managed to reduce fuels (Fulé et al. 2001, Ager et al. 2010, Johnson et al. 2011, Halofsky et al. 2014, Loudermilk et al. 2014).

Several factors may determine the degree to which fuel treatments are effective in reducing the size and severity of wildfires: the type and intensity of the treatment (i.e., how much biomass is removed and how slash is managed; Schwilk et al. 2009), the spatial placement and configuration of fuel treatments across the landscape (Kim et al. 2009, Duncan et al. 2015), the time since treatment (Rhodes and Baker 2008), and the weather conditions at the time of a fire (e.g., wind speed and direction, relative humidity, recent precipitation amounts; Gedalof et al. 2005, Westerling et al. 2006, Stephens et al. 2012). During extreme weather conditions, fuel treatments are less effective at the site level because of the overriding effect of strong winds, low precipitation, low relative humidity, and rapid drying times of fuel beds (Gedalof et al. 2005, Krawchuk and Moritz 2011). However, the increased incidence and spread of 
wildfires during extreme weather events lead to a greater likelihood that wildfire will intersect treatments, which makes treatments more effective at the regional scale than during more moderate weather. In addition, other factors, such as topographic characteristics (e.g., slope, aspect, and elevation), biotic conditions (e.g., tree and shrub species assemblages) and development (e.g., distance from roads or structures) can influence fire spread and behavior as well as the effects of a given fuel treatment on subsequent wildfire activity (Bessie and Johnson 1995, Prichard and Kennedy 2014). Planning for forest management under extreme weather conditions in fueldriven fire systems is critical because fires that occur during these conditions are likelier to escape suppression efforts (Fried et al. 2008) while also being more extensive and more severe than those during years with more moderate weather (Bessie and Johnson 1995). In addition, site-level planning is not sufficient; forest management plans should acknowledge the interaction of patterns and processes across entire landscapes, allowing for and creating shifting mosaics of forest and non-forest patches while maximizing the likelihood that wildfire will intersect treatments. Often, only a small percentage of treatments intersect with a wildfire within the period of time that the altered forest structure can still influence wildfire behavior (Barnett et al. 2016), and spatially optimizing treatments in areas of high fire risk can mitigate the relative risk of fire (Finney 2007, Krofcheck et al. 2017b) while minimizing cost due to the smaller portion of the landscape under treatment. Additionally, applying prescribed fire without 
mechanical treatments has been found to be effective in modifying fuel beds by reducing sapling and shrub density and wood surface fuels (Mclver et al. 2013). Therefore, I sought to understand the effects of fuel treatments (e.g., mechanical thinning and prescribed burning) in a fire-prone, dry mixed-conifer landscape on annual area burned, fire frequency, and fire severity. Specifically, I addressed the following questions:

1. Given a set amount of mechanical thinning on a landscape, does treating additional area with prescribed fire change the effects of an overall fuel treatment plan?

2. If mechanical and prescribed fire treatments are allowed in Riparian Habitat Conservations Areas, will wildfire severity and spread be reduced?

3. How will the effects of fuel treatments on wildfire activity change under extreme weather conditions?

4. Is spatial optimization of fuel treatments as effective as distributed placement at reducing wildfire extent and severity?

To answer these questions, I used a spatially dynamic forest landscape model (FLM) to compare outcomes among different fuel treatment scenarios and under different climate conditions over time. By simulating complex interactions among multiple ecological processes (e.g., plant establishment, competition and mortality, seed dispersal, climate variation and changes over time, and disturbances), FLMs can improve upon the predictive ability of empirical studies and statistical models while allowing for 
spatial variation in conditions, changing conditions through time, and allowing for emergent behavior, e.g. novel conditions (Williams and Jackson 2007). Carefully calibrated FLMs allow forest conditions and disturbance regimes to emerge through simulation and are not constrained by pre-defined states, which facilitates understanding not only beginning and ending points, but continuous trajectories of forest conditions through time (Gustafson 2013). In the case of this study, a modeling approach also allows forcing extreme weather conditions in order to simulate an accelerated frequency of wildfire disturbance. This allowed me to test the effectiveness of fuel treatments on reducing wildfire spread and severity over a much greater number of extreme fire events than has been historically observed on this landscape.

\subsection{Methods}

\subsubsection{Study area}

The study site is located in the southern part of the Blue Mountains (see Chapter 2, Figure 2.1), covering 938,786 ha, of which 666,330 ha are forested, 34,232 ha are potential forest (e.g., recently clear-cut harvested or burned), and 238,224 ha are grasslands and shrublands (LEMMA, 2014). Elevation ranges from $719-2,744$ meters above sea level. Climate in the Blue Mountains is continental with cold, wet winters and hot, dry summers. Mean January and June temperatures are $-3^{\circ} \mathrm{C}$ and $19.3^{\circ} \mathrm{C}$ respectively (1981 - 2010; NOAA 2016, average of 9 weather stations within the study area) with average annual precipitation of 364 mm (1979 - 2014; Abatzoglou 2013), most of which falls as snow (Heyerdahl et al. 2002, NOAA 2016). There is an increase in 
average summer precipitation $(47-55 \mathrm{~mm}$ ) and a corresponding decrease in average summer temperatures $\left(27-25^{\circ} \mathrm{C}\right)$ from the southwest to the northeast of the study area. Climate fluctuations are influenced by the El Niño-Southern Oscillation (ENSO) phenomenon, which is linked to cyclic rising and falling of sea-surface temperatures in the equatorial Pacific Ocean (NOAA 2005). In the Pacific Northwest region, El Niño years are characterized by hot and dry winters and springs (Cayan et al. 1999, Heyerdahl et al. 2002), which in the Blue Mountains is reflected as less than normal snowpack. Dry summer lightning storms are frequent throughout the southern Blue Mountains, and aspect is important in driving moisture and temperature. South-facing slopes have higher surface temperature and lower relative humidity than north-facing slopes, especially on steep slopes (>50\%; Heyerdahl et al. 2001).

Forest association zones in the Blue Mountain region are Juniperus occidentalis, Pinus ponderosa, Abies grandis and Abies lasiocarpa (Franklin and Dyrness 1973). Current forested communities consist primarily of dry Pinus ponderosa (ponderosa pine) and dry mixed-conifer, which is dominated by a mix of ponderosa pine, Pseudotsuga menziesii var. glauca (rocky mountain Douglas fir here-after referred to as Douglas fir), Abies grandis (grand fir), and Larix occidentalis (western larch). Juniperus occidentalis (western juniper) is present in both forest types, although it is not dominant. At higher elevations, Abies lasiocarpa (sub-alpine fir), Pinus contorta var. latifolia (lodgepole pine) and Picea engelmannii (Engelmann spruce) are present, and both Pinus albicaulis (whitebark pine) and Pinus monticola (western white pine) are found in limited 
populations. Riparian areas contain Populus tremuloides (trembling aspen) as well as deciduous shrub species (e.g., Vaccinium spp., Salix spp.) and encroaching young conifers resulting from fire suppression, ungulate browse, and a lowered water table (Dwire et al. 2017) as well as scattered relict conifers greater than 120 years of age. Both low and high-elevation shrublands are dominated by Artemesia spp. (sagebrush) and Purshia tridentata (antelope bitterbrush; LEMMA, 2014).

This area experiences frequent wildfires and is shaped by a legacy of commercial timber harvest (Heyerdahl and Agee 1996) as well as large-scale restoration efforts (USDA Forest Service, Malheur National Forest 2015), making it an appropriate case study to examine the comparative effects of current and accelerated management strategies. The historical fire regime, prior to the advent of aggressive fire suppression around 1900, was frequent with mean fire return intervals between $10.6-28.2$ years across both Ponderosa pine-dominated and mixed-conifer sites (Heyerdahl 1997, Johnston et al. 2016). More recent fire frequency is mediated by active fire suppression, but there continues to be an average of 1.6 fires per year within the study area boundaries and an average of 9,706 ha burned annually for the period $2000-2014$ (Monitoring Trends in Burn Severity 2017). To capture areas of forest and the surrounding grass and shrublands that provide continuous fuels for fire spread, the geographic boundaries of the study site are U.S. Hwy 26 to the north, U.S. Hwy 20 to the south, and include a buffer to the east and west of the National Forest that ranges from approximately $2-30 \mathrm{~km}$. 


\subsubsection{Land ownership and management}

The study area is dominated by federally owned and managed lands (USFS: 570,750 ha; Bureau of Land Management (BLM): 114,008 ha). The remaining land is divided among private ownership (241,971 ha), Oregon State (OR; 11,423 ha), and the Bureau of Indian Affairs (BIA; 153 ha). However, forested land is primarily contained within the USFS boundaries (76\%), and that is where the majority of fuel treatments and biomass harvest takes place.

The Malheur National Forest Land and Resource Management Plan, which laid out desired goals and objectives until the year 2039, was last updated in 1990, and the next plan is currently in development. In the current plan, silvicultural objectives focused on increasing resiliency to insects and increasing "intensive" timber use and aimed to apply uneven-aged management methods to approximately 200,000 acres $(80,937$ ha) with 75,000 acres $(30,351$ ha) being converted from mixed-conifer to ponderosa pine stands. The plan increased prescribed burning to about 1,214 ha per year, which has already been exceeded as forest managers are now typically burning more than twice that amount (approximately 2,830 ha per year) and hope to continue increasing that amount (USFS Fuel Managers, personal communication, February 12, 2016).

\subsubsection{Overview of simulation model}

Changes in forest and fuel bed characteristics over time were simulated with the dynamic forest landscape model LANDIS-II (Scheller et al. 2007), which is widely used to 
simulate forest succession and interactions with disturbances such as fire, harvest, wind, and insects (Scheller et al. 2008, Lucash et al. 2014, Duveneck et al. 2014, Kretchun et al. 2014, 2016, Lucash et al. 2017, Loudermilk et al. 2017). LANDIS-II uses the life history traits of tree and shrub species, along with soil and climate data, to simulate successional trajectories and responses to disturbances over time. Trees are simulated as species-age cohorts, which represent all individual trees of each species as a single group within an age range (e.g., for this study, trees were grouped into 10-year age cohorts). Each cell represents a simulation site on the landscape in which all forested vegetation and topographical conditions are assumed to be homogeneous. Sites can be active or inactive, such as in the case of open water or rocky outcroppings where vegetation is not expected to exist. Processes, such as reproduction, competition, growth, disturbance, and mortality, are simulated both within and between sites (Figure 3.1). LANDIS-II v6.2 was used with the Net Ecosystem Carbon and Nitrogen (NECN) succession extension (v4.2) to simulate vegetation establishment, growth, competition, and mortality. The study landscape was simulated at a resolution of $200 \times 200 \mathrm{~m} \mathrm{(4} \mathrm{ha),}$ and a total of 180 simulation runs were completed for a period of 100 years. 


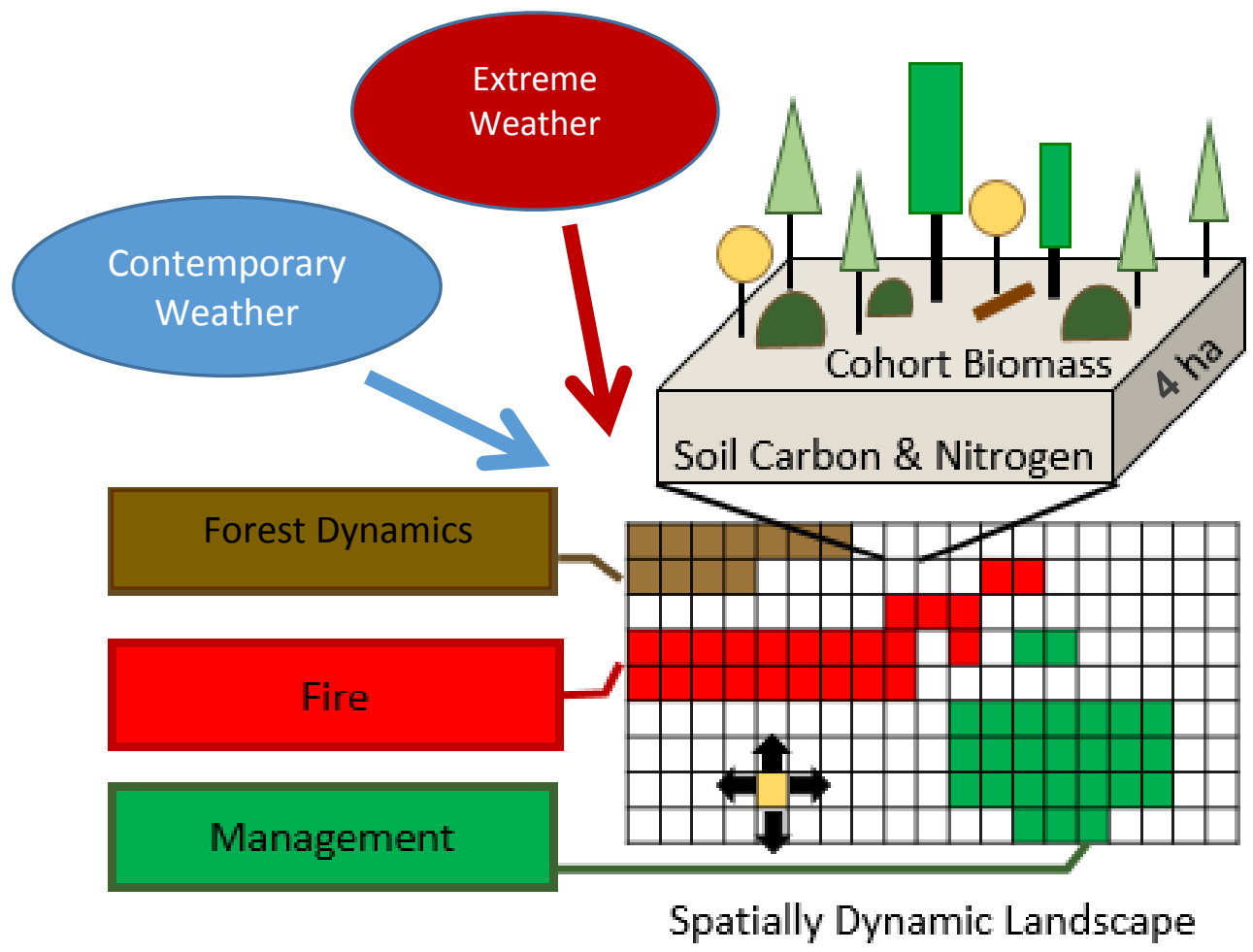

Figure 3.1. The LANDIS-II forest landscape model (FLM) integrates forest successional dynamics with management and disturbance events across space and time. Processes occur within and across each 4-ha cell. The NECN Succession extension simulates complex biophysical above and below-ground processes.

\subsubsection{Model inputs}

\subsubsection{Ecoregions}

Soil and weather data were used to classify the landscape into 25 ecoregions that are assumed to have homogeneous climate and soil moisture conditions. Soil available water was assigned to each cell using SSURGO soil data where they were available; where they were not, SSURGO provisional data and Soil Resource Inventory (SRI) data (Jay Noller, Chris Ringo, Karen Bennett, unpublished data) were used. Cells were reclassified into five soil moisture classes using Natural (Jenks) Breaks in ArcMap 
10.4.1. Maximum temperature and average precipitation for growing season months (June, July, and August) were obtained as 30-year normals (1980 - 2010; PRISM Climate Group) and reclassified into five climate regions using Iso Cluster Unsupervised (see Chapter 2, Figure 2.3).

\subsubsection{Weather data}

For contemporary weather I used daily weather data retrieved from the USGS Data Portal (maximum and minimum temperatures $\left({ }^{\circ} \mathrm{C}\right)$, average precipitation ( $\mathrm{mm} /$ day), daily average wind speed (m/s; Maurer et al. 2002), and wind direction (degrees clockwise from north; Abatzoglou, 2013) for the period 1979 - 2010, using area-weighted grid statistics for each of the five climate regions. To ensure that treatments and fire events would be applied to consistent forest composition and structure across scenarios, historical climate controlled tree growth and forest succession for all scenarios. Therefore, for both contemporary weather and extreme weather scenarios, trees were grown with identical daily weather conditions.

However, a primary objective of this study is to examine the effects of treatment prescriptions on wildfire spread and severity during extreme weather events. To achieve this, climate inputs were decoupled between forest succession and wildfire during extreme weather simulations in order to provide extreme weather conditions for simulation of fire ignition, spread, and resulting tree mortality. These extreme weather inputs were derived from years with greater-than-normal fire activity on the study landscape: 1990, 2007, 2014, 2015, and the entire year's daily precipitation, 
temperature and wind speed and direction data were included with the reasoning that those years' annual conditions contributed to their hotter, drier, and windier than average conditions.

\subsubsection{Vegetation}

LANDIS-II simulates tree and shrub competition and regeneration in each site on the landscape. As a starting point, initial vegetation communities are assigned to each site. Vegetation inputs were leveraged from work completed for Chapter 2. Vegetation data were obtained from the Gradient Nearest Neighbor (GNN) maps obtained through the Landscape Ecology, Modeling, Mapping and Analysis (LEMMA) group (forested areas, Landsat imagery date 2012; https://lemma.forestry.oregonstate.edu/data/home) and the GAP Analysis Program's Ecological Systems map (unforested areas, Landsat ETM+ imagery 1999 - 2001);

https://gapanalysis.usgs.gov/gaplandcover/data/download/). There were 29 tree species identified in forested cells; species that occurred on at least $0.4 \%$ of the landscape were included in this study (11 species, see Chapter 2, Table 2.1). These species were grouped into species-age cohorts in 10-year bins. There were 4,631 unique communities on the landscape, each with up to 11 tree species.

Non-forest cells were assigned to 44 categories from the GAP Analysis Program's Ecological Systems map and were then grouped into five unique non-forest categories based on similar vegetation and fuel characteristics (Disturbed and Invaded Grasslands, Perennial Grasslands, Sagebrush Shrublands, Deciduous Shrublands [Not Flammable], 
and Deciduous Riparian Shrublands [Flammable]) and one inactive category that was not simulated (e.g., open water, bedrock and scree). Using NatureServe Explorer (http://explorer.natureserve.org/servlet/NatureServe?init=Ecol), 45 shrub species that occur in the GAP-identified ecosystem categories in the Blue Mountain region were identified and reclassified into functional groups based on whether they 1 . are nitrogen fixing, 2. resprout after fire, and 3. are shade tolerant (see Chapter 2, Table 2.2). Nonforested cells (e.g., sagebrush shrublands, perennial grasslands, etc.) were assigned cohorts of these shrub-groups based on the combinations of individual shrub species that occur in each non-forest category. Shrubs were also included in forested cells where reported in the GNN Understory inventory. Disturbed and Invaded Grasslands and Perennial Grasslands were assigned invasive and native grasses respectively in order to provide grass fuel-types and to allow fires to spread through cells that do not contain either trees or shrubs.

\subsubsection{Model parameterization and validation}

Model parameterization and validation were leveraged from the work done in Chapter 2.

\subsubsection{Forest succession}

The Net Ecosystem Carbon and Nitrogen Succession (NECN) extension in LANDISII includes aboveground and belowground $\mathrm{C}$ and $\mathrm{N}$ pools that follow the CENTURY soil model (Parton et al. 1993). Temperature and precipitation at monthly time-steps control vegetation growth and reproduction. Model parameters were obtained from the 
literature and available datasets including the USDA Fire Effects Information System (https://www.feis-crs.org/feis/), USGS Vegetation Atlas of North America (https://pubs.usgs.gov/pp/p1650-a/), the Northeastern Ecosystem Research Cooperative's Foliar Chemistry Database (http://www.nercscience.org/Metadata_FoliarChemistry.html), the National Atmospheric Deposition Program (http://nadp.sws.uiuc.edu/NTN/ntnData.aspx), and the Oak Ridge National Laboratory database (https://daac.ornl.gov/SOILS/guides/West Soil_Carbon.html) and from previous studies that utilized LANDIS-II species parameterization (Loudermilk et al. 2014, Lucash et al. 2014, Creutzburg et al. 2016). A full list of parameters that were calibrated are included in the online repository listed in Appendix A.

NECN Succession "spins up" to the start year of the simulation by iterating succession at the number of time steps equal to the oldest cohort in each site allowing comparison between simulated biomass and observed biomass. Biomass and growth validation was accomplished by comparing aboveground tree biomass (total and species-specific) with Forest Inventory Analysis (FIA) data. Simulated total biomass ranged from 0 to $105 \mathrm{Mg} / \mathrm{ha}$ with a mean value of $45 \mathrm{Mg} / \mathrm{ha}$, while biomass estimates from FIA data ranged from $0-236 \mathrm{Mg} / \mathrm{ha}$ with a mean of $45 \mathrm{Mg} / \mathrm{ha}$. These results show that while the model did not simulate the full range of variability in total biomass, it sufficiently captured average biomass and adequately reproduced tree growth. Validation of each of the 11 modeled tree species was performed by comparing average 
species-level biomass in cells where that species occurs with GNN data for that species.

Out of the 11 tree species simulated, nine achieved average biomass within $30 \%$ of GNN (see Chapter 2, Figure 2.8).

\subsubsection{Fuel Treatments}

Fuel treatments were conducted through simulated harvest of trees and prescribed fire using the Biomass Harvest (v3.2) extension. This extension uses management maps (e.g., USFS, BLM, etc.) and stand maps to define treatable areas and ranks stands for harvest or prescribed fire based on user-defined parameters including species, age, economic value, or fire hazard. I defined prescriptions for each forest type as laid out in the fuel treatment scenarios discussed in section 2.4 and designated the percentage of each management area to be treated per decade. Mechanical harvest treatments ranged from pre-commercial thinning of small-diameter (young) cohorts to commercial harvest of large-diameter (older) cohorts. Prescribed fire treatments were designed to emulate the proportion of shrubs and trees removed during underburning (T. Boyce, personal communication, February 12, 2016). Output data for each scenario at each timestep included area treated with each prescription type, number of cohorts removed of each species, and biomass $(\mathrm{Mg})$ removed of each species.

\subsubsection{Wildfire}

Two versions of the Dynamic Fire and Fuels System (DFFS) extensions (Sturtevant et al. 2009) simulated wildfire disturbance and interactions with climate and fuels. Extreme weather fire simulations were completed using DFFS v2.1, which allows a 
separate input file for fire weather than that for the NECN Succession extension. (See section 3.3.1.2 for more information about extreme fire weather inputs.) DFFS v3.0 (unpublished), which links weather between NECN and DFFS, was used for contemporary-weather scenarios to simulate fire events with the same daily weather conditions that control vegetation growth. Both versions of DFFS utilize vegetation succession data from NECN, dynamically changing fuel beds based on current vegetation. Fuel types were developed to represent 15 unique combinations of tree species and ages, as well as shrublands and grasslands, with individual fire behavior and consumption parameters. Landscape topography, which affects fire spread rates, was integrated via slope and aspect maps.

Fire was calibrated to approximate annual area burned (mean 9,706 ha, median 615 ha, range of $0-81,010$ ha, standard deviation 24,481 ha) and fire size (mean 6,933 ha with a range of $434-56,484$ ha) for the period $2000-2014$ in the study area. (Multiple small fires with the same wildfire designation were considered one fire.) This 15-year period was selected because it reflects the most recent fire activity on the study landscape allowing calibration of the model to reflect current conditions. Historical fire data were retrieved from the Monitoring Trends in Burn Severity database (2016) and the USFS (Blue Mountains Fire History Polygons, released 2016). Simulated fire sizes were first calibrated by limiting the maximum fire size to achieve a distribution equivalent to the historical period and to reconstruct fire duration from these simulated fires. Calibration simulations were then run as duration-limited, which allows for the 
possibility of larger fires and greater annual area burned reflecting the influence of dynamic vegetation and weather over time (Sturtevant et al. unpublished). The DFFS extension uses log-normal duration data to generate the distribution of fire durations, which was then used to calibrate annual area burned, which also follows a log-normal distribution (see Chapter 2, Figure 2.9). Three replicates of 50 years were then run and averaged to validate the calibration, achieving a mean of 10,400 ha burned annually with a range of $0-134,700$ ha.

\subsubsection{Simulation scenario design}

I used scenarios to compare among: 1 . weather scenarios (contemporary weather vs. extreme fire weather); 2 . management extent scenarios (i.e., treating more and less area with prescribed fire per year and adding treatments in riparian areas); and 3. spatial scenarios, i.e., distributing treatments across the landscape vs. targeting areas with high fire risk (hereafter "distributed" and "optimized"). In February 2016, a workshop was held with USFS personnel including fuels planners/managers and ecologists, and follow-up email and phone meetings were held with two forest silviculturists. During these meetings, "business as usual" fuel treatment prescriptions were defined and comparative scenarios were developed. Fuel treatment prescriptions included biomass harvest (i.e., mechanical thinning) for ponderosa pine, dry mixedconifer and moist mixed-conifer forest, pre-commercial thinning, and prescribed burning. Management scenarios included five variations: 1. untreated landscape, 2. "business as usual" (BAU) management, 3. additional treatments in Riparian Habitat 
Conservation Zones (hereafter referred to as riparian areas), 4. application of additional prescribed fire ( $2 x$ the area of $B A U)$, and 5. tripled application of additional prescribed fire ( $3 x$ the area of BAU). These scenarios allowed comparisons that help us understand how effective BAU prescriptions will be at reducing wildfire activity under extreme climate conditions, and they are designed to help answer federal forest management questions about the impacts of treating in riparian areas and adding acreage of prescribed fire.

All scenarios were run under both contemporary and extreme weather conditions, and each of the three management scenarios that include treatments (i.e., all except the untreated scenario) were run with fuel treatments placed through two different spatial strategies: 1 distributed across the entire forested portion of the landscape (excluding protected areas) and 2. with optimized placement of treatments in areas of the landscape that have the highest probability of high severity fire. Ten replicates of each simulation were run for 100 years to capture variability and to allow for comparisons among scenarios over time. See Figure 3.2 for a conceptual model of the scenario design. 


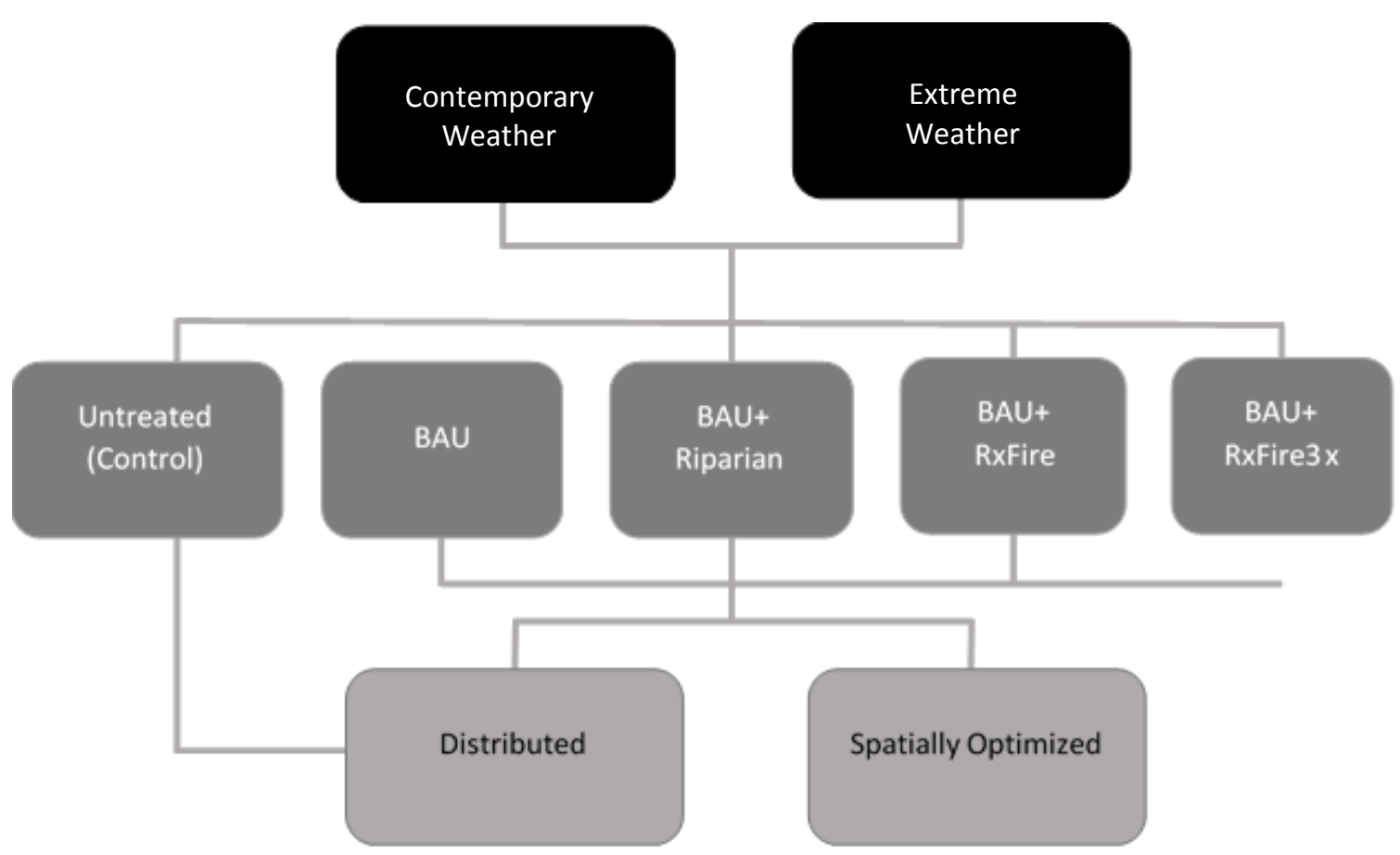

Figure 3.2. Matrix of weather, harvest, and spatial placement scenarios. Weather scenarios included contemporary and extreme weather. Management scenarios included Untreated (no management), Business-as-Usual (BAU), which is modeled after current management strategies, Business-as-Usual plus additional area treated in Riparian Habitat Conservation Areas (BAU+Riparian), and Business-as-Usual plus additional prescribed fire (BAU+RxFire and BAU + RxFire3x). Active management (all except the control) were simulated with distributed and spatially optimized treatments.

\subsubsection{Hot spot treatment areas}

To assess whether treatment placement optimization is effective in slowing the spread and reducing the severity of wildfire, I identified areas on the landscape that were the most likely to burn with high severity. Ten replicates of untreated landscape simulations under extreme weather conditions for 100 years were compiled and assigned an index value based on severity and frequency of burning. This was accomplished by compiling fires of severity 4-5 (indicating crown fraction burned of $0.495-1.0)$, and tabulating the number of times each cell burned at that severity over 
1000 simulation-years. The resulting index ranged from $0-700$, and only sites with a value of at least 450 were retained (indicating that in any given year a cell has a 12.5 $17.5 \%$ chance of burning at severity 4 and an $8-14 \%$ chance of burning at severity 5$)$. Optimized treatment areas were identified by overlaying a map of these high-severity fire-prone locations with a map of forested portions of the landscape that are legally available for treatment. On federally and state-managed lands, treatments were concentrated in these high-risk areas; treatment placement was not altered on lands managed by private owners. The effectiveness of distributing management across the landscape (Figure 3.3a) was compared with spatially optimizing treatments (Figure 3.3b).
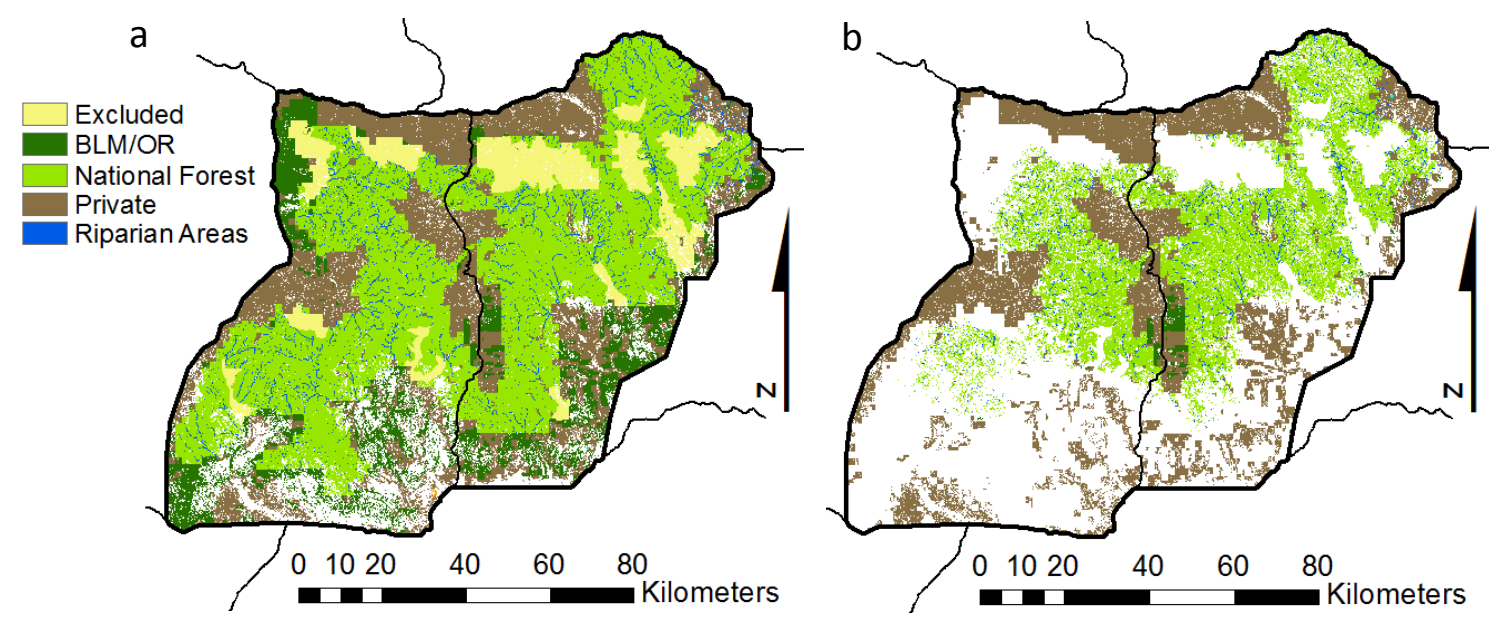

Figure 3.3. Distributed (a.) and spatially optimized (b.) management areas. About half of the land is under USDA Forest Service management, with the remainder divided among private landowners and other federal and state agencies. Yellow polygons in map (a) indicate areas that are excluded from management, such as wilderness and designated old growth habitat. In order to determine whether concentrating fuel reduction treatments in areas at high risk for frequent wildfire at high severity is as effective at reducing wildfire spread and severity as distributing those treatments across the landscape, 1000 simulation-years were run with no management. Areas that frequently burned and where wildfire severity was highest were identified.

Treatments on National Forest, BLM and Oregon State were concentrated in these high-priority 
areas, while management on private lands was not adjusted. As with the distributed treatment scenarios, riparian areas remained available for treatment only in the BAU+Riparian scenario.

\subsubsection{Scenario Descriptions}

Untreated: Simulations of the untreated landscape were run as a control to compare the effects of the other treatment scenarios against no treatment.

Business as Usual (BAU): This scenario was designed to emulate current management practices on both publically-managed and privately-owned land. On USFS land, this consisted of pre-commercial thinning of understory trees up to $23 \mathrm{~cm}\left(9^{\prime \prime}\right)$ diameter at breast height (DBH), commercial harvest of grand fir, lodgepole pine, western juniper, and some harvest of ponderosa pine, Douglas fir, and western larch up to $53 \mathrm{~cm}\left(<21^{\prime \prime}\right)$ $\mathrm{DBH}$. Area harvested per decade was 40,500 ha (100,000 acres) divided equally between forest dominated by ponderosa pine, dry-mixed conifer forest, and moist-mixed conifer forest. Ponderosa pine and dry-mixed conifer forest were treated with prescribed fire immediately after harvest and again after 10 years. Prescribed fire was designed to reproduce the effects of a 1.2-m (4-foot) flame length, removing small-diameter trees of all species as well as most shrubs and post-harvest slash, and these stands were assigned to a fuel-type with low flammability for 15 years (ponderosa pine forest) and 10 years (dry-mixed conifer forest) following the prescribed burn treatment. Prescribed fire was not applied following treatments in moist mixed-conifer forest.

Pre-commercial thinning was applied to 12,000 ha (30,000 acres) per decade with sites selected based on the presence of fire-prone fuels (especially young mixed conifer and areas with a dense mix of deciduous trees, shrubs and grand fir). 
Approximately $80 \%$ of stems up to $28 \mathrm{~cm}\left(11^{\prime \prime}\right)$ were removed, and prescribed fire was applied immediately and again after 10 years. These stands were also assigned to a fueltype with low flammability for 10 years following each treatment, reflecting the removal of ladder and small diameter fuels.

Forested lands managed by BLM and the Oregon Department of Forestry were treated with small harvests designed to emulate timber harvest and small stewardship contracts. Harvest sites were selected based on a preponderance of ponderosa pine, Douglas fir, and grand fir of at least 40 years, and approximately 4,000 ha (9,880 acres) were harvested per decade.

Privately-owned forest sites were prioritized based on the presence of harvestable Douglas fir, ponderosa pine, western large, and grand fir of at least 40 years, and the oldest cohorts of each species were harvested. On average, 7,148 ha $(17,870$ acres) were harvested per decade on private lands.

Added Riparian Treatments (BAU+Riparian): This scenario included all treatments from the BAU scenario but added additional area treated in riparian areas. On a 50-year rotation, riparian areas were treated with restoration or prescribed burn-only treatments. The restoration treatment was designed to favor broadleaved trees and fire-tolerant species and removed most (99\%) of all harvestable conifer species between 0-10 years of age, $80-90 \%$ of mid-aged conifers (between $30-80$ years of age, depending on species), but left relict trees of all species. Sites in this category received 
prescribed fire immediately following tree removal and again after 10 years. Sites that received only prescribed fire were not revisited.

Increased Prescribed Fire Treatments (BAU+RxFire): This scenario included all treatments from the BAU scenario and added an additional 21,000 ha (51,892 acres) of prescribed burning per decade. Sites were selected based on the presence of high-risk fuel types (e.g., young mixed conifer).

Tripled Prescribed Fire Treatments (BAU+RxFire3x): This scenario included all treatments from the BAU scenario and added an additional 61,500 ha $(153,860$ acres $)$ of prescribed burning per decade. Sites were selected based on the presence of high-risk fuel types (e.g., young mixed conifer).

Table 3.1. Management scenarios and area treated. Area reported is the average area across replicates for the first two decades of simulation under contemporary weather. Over time, area available for treatment fluctuates due to changes in forest dynamics and wildfire activity. Under extreme weather, less area was available for harvesting over time due to mortality from wildfire disturbance.

\begin{tabular}{|l|c|c|}
\hline Scenario & Area harvested (ha/decade) & Area of Rx Fire (ha/decade) \\
\hline Untreated & 0 & 0 \\
\hline Distributed Placement & & 26,252 \\
\hline BAU & 64,225 & $+4,084$ \\
\hline BAU+Riparian & $+5,103$ & $+22,039$ \\
\hline BAU+RxFire & +0 & $+61,556$ \\
\hline BAU+RxFire3x & +0 & \\
\hline Optimized Treatment & & 28,446 \\
\hline BAU & 63,709 & $+4,276$ \\
\hline BAU+Riparian & $+4,259$ & $+21,364$ \\
\hline BAU+RxFire & +0 & $+62,220$ \\
\hline BAU+RxFire3x & +0 & \\
\hline
\end{tabular}




\subsubsection{Analysis}

Annual area burned, fire frequency, and fire severity were compared among harvest and weather scenarios and between treatments placed across the entire forested landscape and those placed only within the spatially optimized treatment areas. Statistical analysis was completed for annual area burned and fire severity data. Annual area burned data followed a log-normal distribution, therefore analysis was conducted on log-transformed data. Following Bartlett's test for homoscedasticity, analysis of variance and Tukey's honestly significant difference tests were run to differentiate means. For non-normally distributed severity data, a Kruskal-Wallis test was used with post hoc Dunn's test for ranked comparisons. All model calibration and analysis were completed in RStudio 1.0.153 using R x64 3.4.1.

\subsection{Results}

\subsubsection{Riparian Treatments}

The addition of fuel treatments in riparian areas did not result in any differences in wildfire activity at the landscape scale from the BAU scenario. Therefore, there will not be any further discussion of riparian treatment results in this section.

\subsubsection{Treatment effects on fire metrics}

\subsubsection{Annual area burned}

Overall, treatment reduced area burned under both historical and extreme weather $(0.000<p<0.02$, Table 3.2). Doubling the area treated with prescribed fire resulted in small additional reductions in average annual area burned, and tripling the 
area of prescribed fire resulted in a significant reduction from the BAU scenario $(p<$ 0.006). Increasing treatment area also increased the number of years without any fire at all under both contemporary weather (from 139 years out of a possible 1,000 simulation years under BAU to $166 / 208$ years with $B A U+R x F i r e / B A U+R x F i r e 3 x$ respectively) and extreme weather (from 117 years to 132/172 years).

Spatial optimization of treatments into high-risk areas of the landscape was equally effective in reducing annual area burned, regardless of weather, for 5 out of the 6 scenario combinations $(p=1.0)$. The exception was RxFire $3 x$ under extreme weather, where spatially optimized treatments resulted in greater area burned than distributed treatments $(p=0.000$; Figure 3.4).

Table 3.2. Multiple post-hoc comparison results from Tukey's honestly significant difference of means following a significant result from analysis of variance (contemporary weather: $\mathrm{df}=6, F=$ 10.38, $p<0.00001$; extreme weather: $\mathrm{df}=6, \mathrm{~F}=13.81, \mathrm{p}<0.00001)$. Results are reported as the difference in log-transformed value of column - row/p-value (alpha $=0.05$ ). A positive difference value indicates that the column scenario produced higher area burned than the row scenario. Significant results are marked with an *. All treatment scenarios led to significantly lower annual area burned as compared with no treatment. Tripling the level of prescribed fire per year (RxFire3x) significantly reduced area burned compared with business as usual (BAU) for both weather conditions, and under contemporary weather, spatial optimization of RxFire3x did not significantly change its effectiveness. However, under extreme weather, spatially optimizing RxFire $3 x$ was less effective in reducing annual area burned.

\begin{tabular}{|l|l|l|l|l|l|l|}
\hline $\begin{array}{l}\text { Contemporary } \\
\text { Weather }\end{array}$ & BAU & Opt_BAU & RxFire & Opt_RxFire & RxFire3x & Opt_RxFire3x \\
\hline Opt_BAU & $\begin{array}{l}0.12 / \\
0.99\end{array}$ & & & & & \\
\hline RxFire & $\begin{array}{l}0.32 / \\
0.38\end{array}$ & $0.20 / 0.85$ & & & & \\
\hline Opt_RxFire & $\begin{array}{l}0.20 / \\
0.86\end{array}$ & $0.08 / 1.0$ & $\begin{array}{l}-0.12 / \\
0.99\end{array}$ & & & \\
\hline RxFire3x & $\begin{array}{l}\mathbf{0 . 5 9 /} \\
\mathbf{0 . 0 0 6 *}\end{array}$ & $\begin{array}{l}\mathbf{0 . 4 7 /} \\
\mathbf{0 . 0 5 *}\end{array}$ & $\begin{array}{l}0.27 / \\
0.60\end{array}$ & $0.39 / 0.18$ & & \\
\hline
\end{tabular}




\begin{tabular}{|c|c|c|c|c|c|c|}
\hline Opt_RxFire3x & $\begin{array}{l}0.30 / \\
0.47\end{array}$ & $0.18 / 0.91$ & $\begin{array}{l}-0.02 / \\
1.0\end{array}$ & $0.10 / 1.0$ & $\begin{array}{l}-0.29 / \\
0.51\end{array}$ & \\
\hline Untreated & $\begin{array}{l}-0.54 / \\
0.014^{*}\end{array}$ & $\begin{array}{l}-0.66 / \\
0.001^{*}\end{array}$ & $\begin{array}{l}-0.86 / \\
0.0000 *\end{array}$ & $\begin{array}{l}-0.74 / \\
0.0002 *\end{array}$ & $\begin{array}{l}-1.3 / \\
0.0000 *\end{array}$ & $\begin{array}{l}-0.84 / \\
0.0000^{*}\end{array}$ \\
\hline \multicolumn{7}{|l|}{$\begin{array}{l}\text { Extreme } \\
\text { Weather }\end{array}$} \\
\hline Opt_BAU & $\begin{array}{l}-0.17 / \\
0.96\end{array}$ & & & & & \\
\hline RxFire & $\begin{array}{l}0.28 / \\
0.67\end{array}$ & 0.44 / 0.14 & & & & \\
\hline Opt_RxFire & $0.10 / 1.0$ & $0.27 / 0.69$ & $\begin{array}{l}-0.17 / \\
0.95\end{array}$ & & & \\
\hline RxFire3x & $\begin{array}{l}0.75 / \\
0.0008 *\end{array}$ & $\begin{array}{l}0.91 / \\
0.0000 *\end{array}$ & $\begin{array}{l}0.47 / \\
0.10 \\
\end{array}$ & $\begin{array}{l}0.64 / \\
0.006^{*}\end{array}$ & & \\
\hline Opt_RxFire3x & $0.07 / 1.0$ & $0.24 / 0.80$ & $\begin{array}{l}-0.21 / \\
0.89\end{array}$ & $-0.03 / 1.0$ & $\begin{array}{l}-0.67 / \\
0.003 *\end{array}$ & \\
\hline Untreated & $\begin{array}{l}-0.73 / \\
0.001 *\end{array}$ & $\begin{array}{l}-0.56 / \\
0.02 *\end{array}$ & $\begin{array}{l}-1.01 / \\
0.0000^{*}\end{array}$ & $\begin{array}{l}-0.83 / \\
0.0001 *\end{array}$ & $\begin{array}{l}-1.48 / \\
0.0000^{*}\end{array}$ & $\begin{array}{l}-0.80 / \\
0.0002^{*}\end{array}$ \\
\hline
\end{tabular}



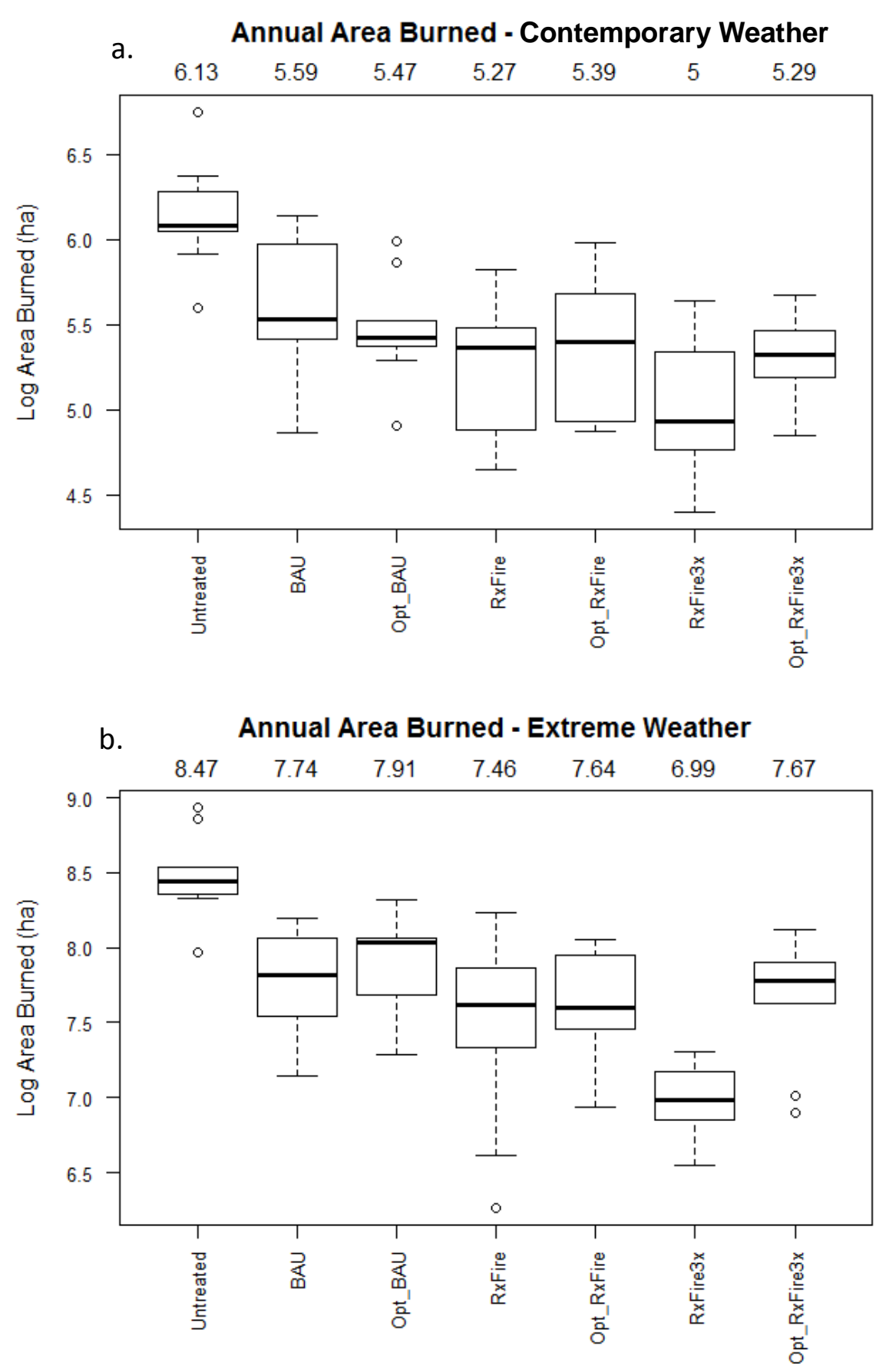

Figure 3.4. Boxplots of annual area burned under contemporary (a.) and extreme (b.) weather for each management scenario. Under both weather scenarios, fuel treatments reduced annual area burned as compared with the untreated landscape $(p=0.0)$. Doubling the area treated with prescribed fire was not sufficient to significantly reduce area burned (Contemporary: $p=0.22$, Extreme: $p=1.0$ ), but tripling the area treated with prescribed fire resulted in significant decreases under both contemporary $(p=0.0008)$ and extreme weather $(p=0.0005)$. Spatially 
optimizing treatments resulted in similar annual area burned for each treatment type under contemporary weather (i.e., no significant differences), indicating that under moderate conditions, concentrating treatments in areas with high likelihood of burning at high severity is effective. However, under extreme weather, RxFire $3 x$ was more effective when distributed across the landscape $(p=0.019)$. In this figure, area burned is expressed as the natural log, and log-mean values for annual area burned are listed above each corresponding box.

\subsubsection{Fire frequency}

Wildfire was most frequent on the untreated landscape, with treatment reducing fire incidence from a maximum of 48 fires per cell (Untreated) to a maximum of 29 fires per cell (RxFire3x) out of 1,000 chances to burn. Treatment of any type led to less frequent fire in all areas of the landscape with the greatest reductions in the central and southwestern portions. Spatially optimizing treatments was similarly effective in reducing fire occurrence as distributing treatments and resulted in similar spatial patterns of fire occurrence. Under extreme weather, a greater proportion of the landscape, especially in the central part of the study area, was likely to burn. Spatially optimizing treatments reduced fire frequency in the areas treated (central and northeastern areas) but resulted in greater area burned in the untreated portion of the landscape (southwestern areas) with this effect most pronounced in the RxFire $3 x$ scenario (Figure 3.5). 


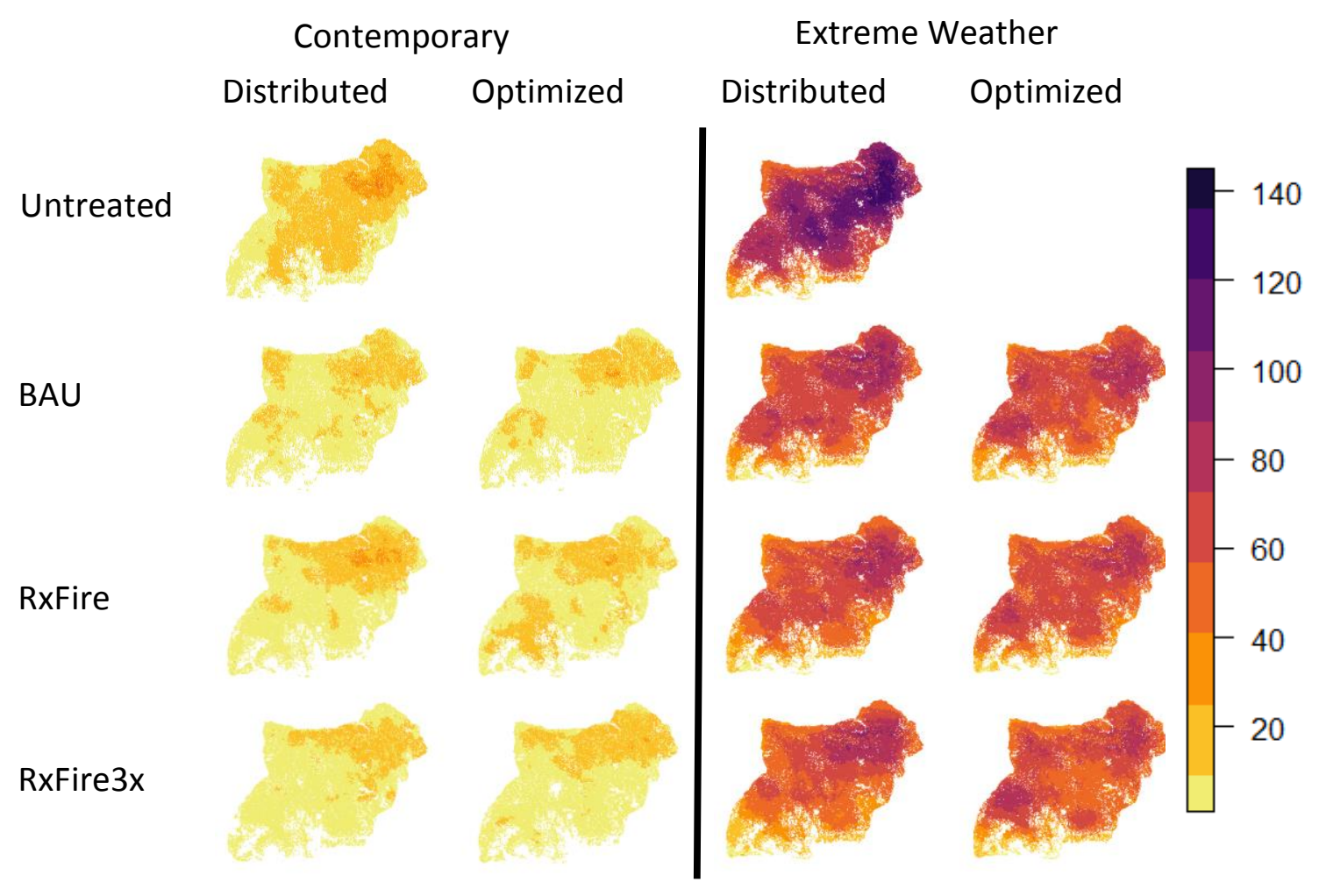

Figure 3.5. Maps of total fire occurrence at each site over all replicates and years. Scale represents the number of fires that occurred in each individual cell over 100 years and 10 replicates. Fire was more likely over a greater proportion of the landscape under the Untreated scenario, and with management, the southwestern portion of the landscape was less likely to burn. Spatially optimizing treatments was similarly effective in reducing fire occurrence as distributing treatments and resulted in similar spatial patterns of fire occurrence. Under extreme weather, a greater proportion of the landscape, especially in the central part of the study area, was likely to burn. Spatially optimizing treatments reduced fire occurrence in the areas treated (central and northeastern areas) but resulted in greater area burned in the untreated portion of the landscape (southwestern areas) with this effect most pronounced in the RxFire3x scenario.

Mean fire return interval (MFRI) is a measure that characterizes the frequency of fire at the site or stand level and is averaged across stands to give a measure of landscape-level fire frequency. However, at this landscape-scale of just under 1 million ha, the measure is less useful because as area increases the MFRI decreases (Agee 1993). For example, under contemporary weather, the MFRI of the landscape with BAU 
management is 1.16 years, which reflects that there are very few years in which there is no fire anywhere on the landscape. In contrast, fire history studies of individual stands in the study area have yielded MFRI values of $10.6-28.2$ years (Johnston et al. 2016). A better measure of frequency for landscapes of this size is fire rotation period (FRP), which is related to both fire frequency and annual area burned. FRP is the number of years it would take for an area equivalent to the size of the study area to burn (Agee, 1993). Higher numbers indicate longer durations, which is equivalent to less frequent and/or extensive wildfire. FRP of the untreated landscape under contemporary weather was 90.53 while BAU management was 157 years, reflecting the significant reduction in annual area burned. Again, tripling the amount of area treated with prescribed fire resulted in the greatest impact with an FRP of 170 years. Under extreme weather simulations, fire frequency is based on forcing a much higher number of simulated fires than would be expected under normal conditions, and therefore FRP should be considered as an index to compare among treatments and not as a realistic number of years. FRP for the untreated landscape was 12.1 years, and treatment increased it to a range of 16.5 years (BAU) to 19.0 years (RxFire $3 x$ ). Likewise, FRP was similar for optimized and distributed treatments except for RxFire3x, where FRP decreased from 19.01 to 18.28 years when treatment placement was optimized.

\subsubsection{Fire severity}

Fuel treatment effects on fire severity were apparent at individual sites (Figure 3.6), and severity reductions were most effective in the treated portions (i.e., forested 
areas) of the landscape. Under contemporary weather, reductions in severity at the landscape scale were not statistically significant $(p=0.165)$, and increased area treated with prescribed fire did not provide a significant further reduction in landscape-level fire severity. However, under extreme weather, all treatment scenarios had significantly lower severity than Untreated $(0.0000<p<0.001)$, and resulted in a $9-11 \%$ decrease in severity (Figure 3.7). The most effective treatment scenarios were spatially optimized BAU and distributed RxFire3x, both which resulted in 11\% decreases in severity.

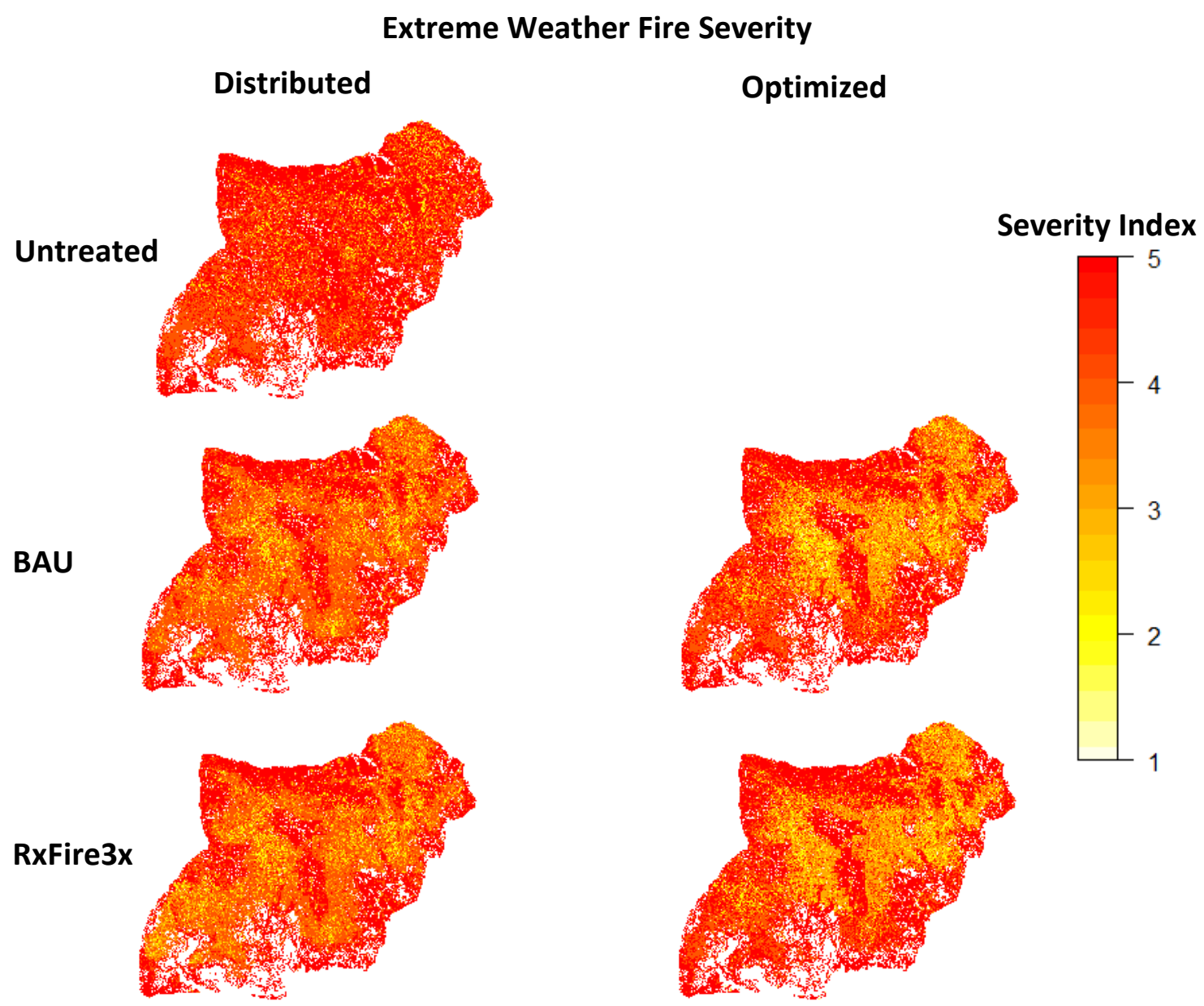

Figure 3.6. Mean fire severity under extreme weather compared between distributed and spatially optimized treatments for the BAU and RxFire3x scenarios. All treatment scenarios 
reduced mean fire severity as compared with the untreated landscape. Although spatially optimizing treatments decreased severity in treated areas of the landscape, it resulted in slight (BAU) and significant (RxFire3x) increases in landscape-level mean severity because of higher severity in untreated areas of the landscape. The outer perimeter of the study landscape is dominated by grassland and shrublands, which experienced high-severity fires under all scenarios.

a. Fire Severity - Contemporary Weather

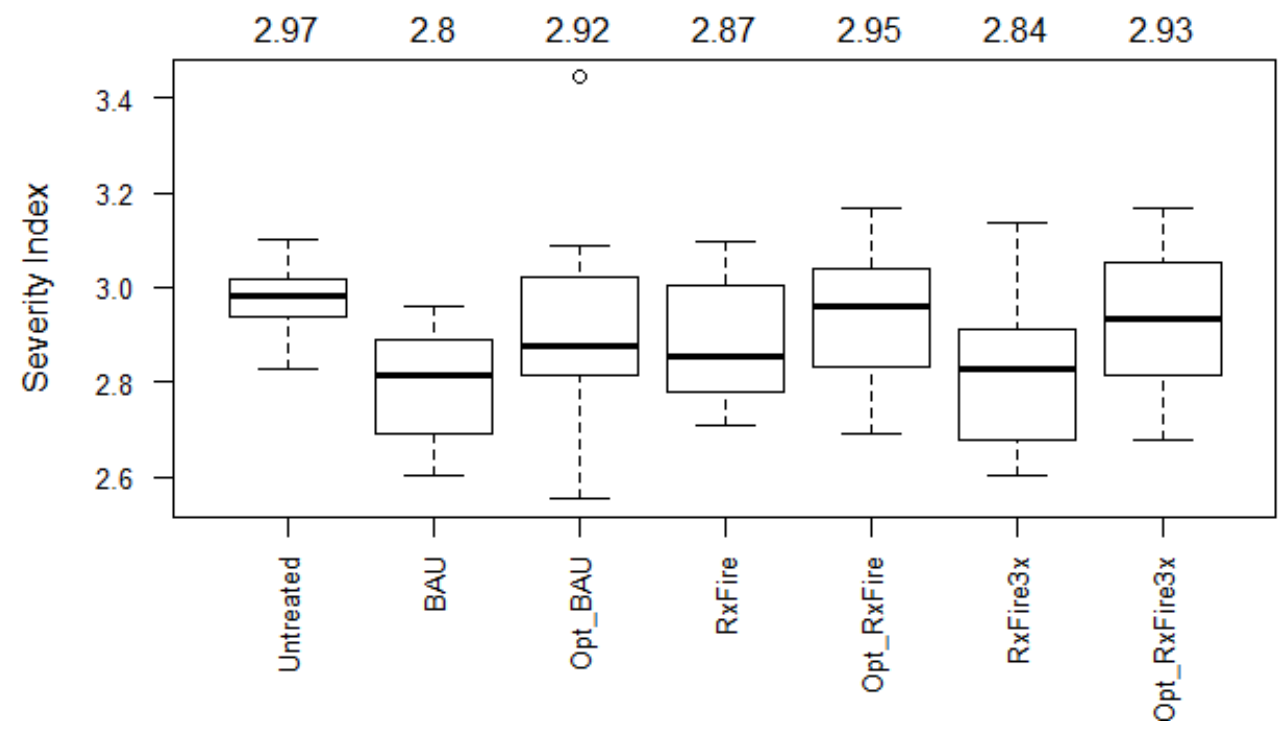

b.

Fire Severity - Extreme Weather

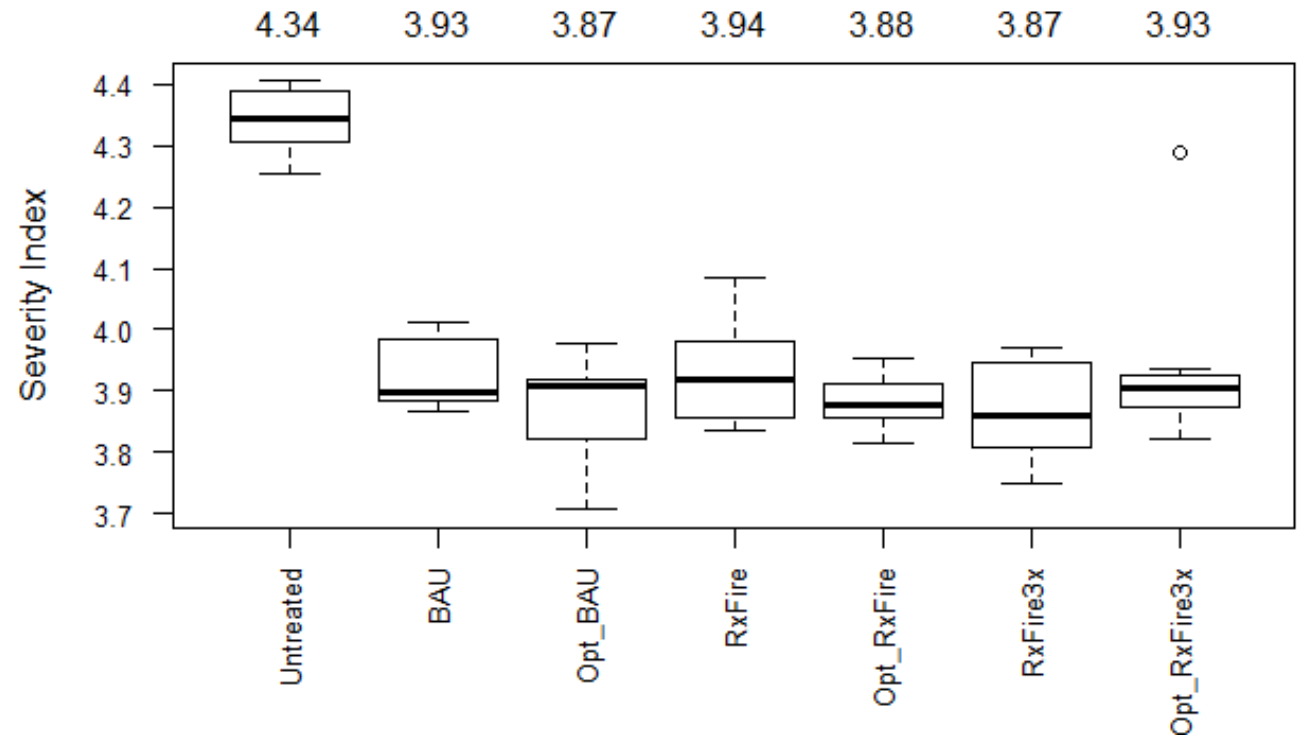

Figure 3.7. Boxplots of fire severity in forested portions of the landscape under contemporary (a.) and extreme (b.) weather for each management scenario. Under contemporary weather, treatment scenarios reduced severity for sites that burned, although those reductions were not 
statistically significant $(p=0.17)$. Spatially optimizing treatments led to slight increases in fire severity because of fewer intersections of wildfire with recently treated sites. Under extreme weather, treatment significantly reduced mean severity $(p=6.335 e-05)$ compared with the untreated landscape, and optimizing treatment placement in all but the optimized RxFire3x scenario led to further decreases in severity.

Spatial optimization of treatments in areas at high risk for frequent, high-severity fire reduced average severity from 3.93 to 3.87 . This decrease was primarily due to a greater proportion of fires in the severity range of $2.5-3.5$ as compared with nonoptimized treatment placement and a smaller proportion of fires in the severity range of 3.6 - 4.3. However, this benefit was somewhat offset by an increase in the proportion of high-severity fires in the $4.4-4.8$ severity range (Figure 3.8 ) under spatially-optimized treatment placement, and spatially optimizing the RxFire3x scenario resulted in higher landscape-level severity. This was due to a reduction in area available to harvest over time, leading to fewer sites treated and less biomass harvested/removed through prescribed fire as compared with the distributed treatments.

\section{a. Mean Fire Severity - Contemporary Weather}

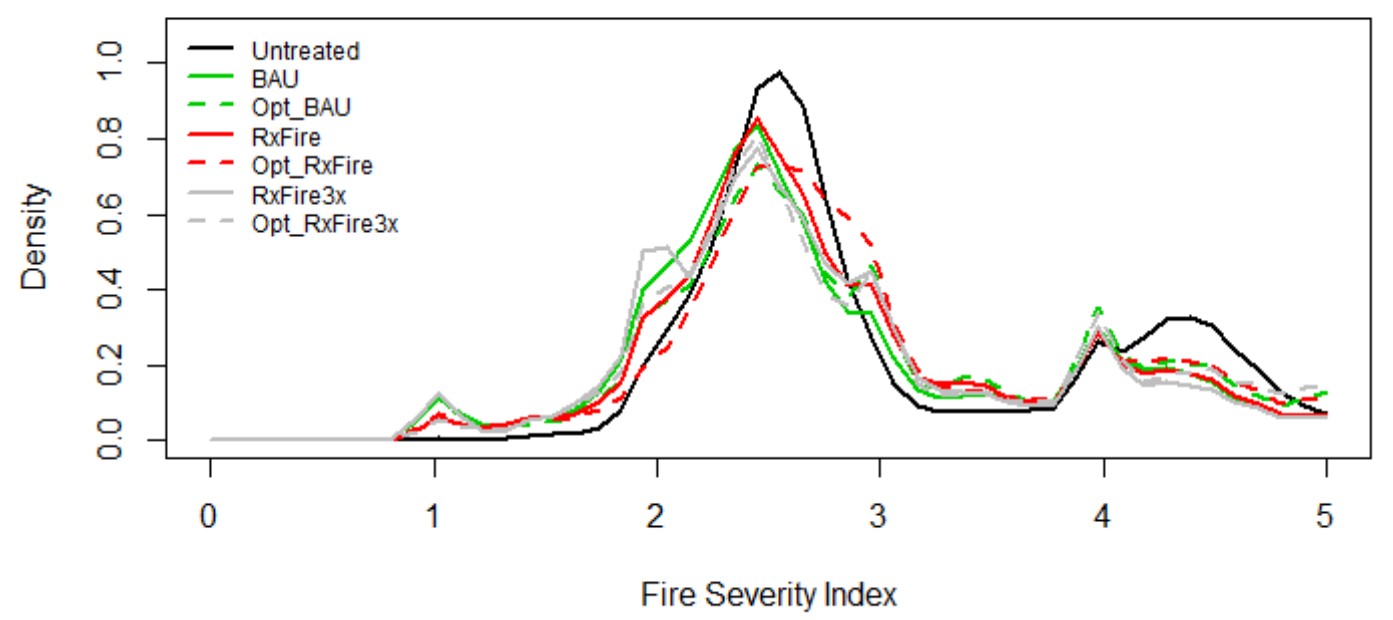




\section{b. Mean Fire Severity - Extreme Weather}

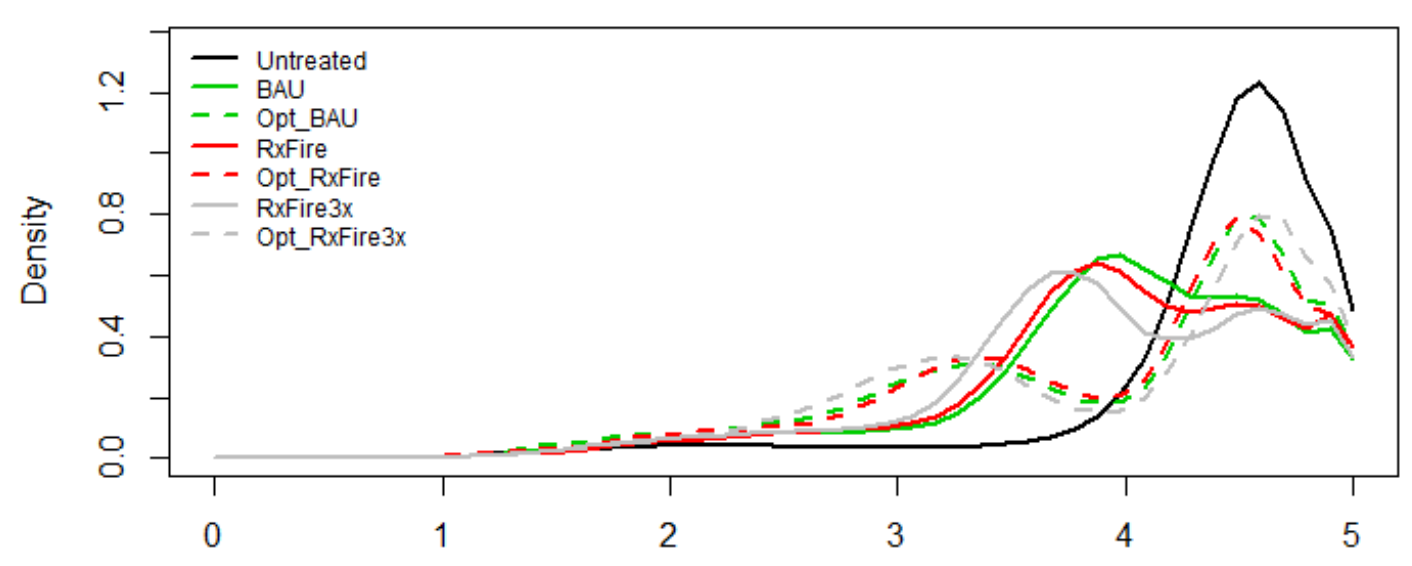

Fire Severity Index

Figure 3.8. Density plots of mean fire severity under historical and extreme weather. Active management reduced mean fire severity under both historical (a.) and extreme (b) weather scenarios, and tripling the amount of area treated with prescribed fire produced the greatest reductions. Under extreme weather, spatial optimization of fuel treatments further reduced mean fire severity, with the greatest reduction in fires in the 3.3 -4.2 range of severities.

Table 3.3. Comparison of management scenarios' effects on wildfire annual area burned and severity for 1 . contemporary and extreme weather and 2 . distributed and optimized treatment placement.

\begin{tabular}{|c|c|c|}
\hline & Contemporary Weather & Extreme Weather \\
\hline $\begin{array}{l}\text { Distributed } \\
\text { Placement }\end{array}$ & $\begin{array}{l}\text { - } \text { Active management } \\
\text { reduced annual area } \\
\text { burned, but reductions } \\
\text { to severity were not } \\
\text { statistically significant. } \\
\text { - Doubling the area } \\
\text { treated with prescribed } \\
\text { fire was not sufficient to } \\
\text { reduce annual area } \\
\text { burned or severity at the } \\
\text { landscape level. } \\
\text { Tripling the area treated } \\
\text { significantly reduced } \\
\text { area burned. }\end{array}$ & $\begin{array}{l}\text { - } \\
\text { reductive management annual area } \\
\text { burned and wildfire } \\
\text { severity. } \\
\text { Doubling the area treated } \\
\text { with prescribed fire } \\
\text { reduced annual area } \\
\text { burned, but had no effect } \\
\text { on severity. } \\
\text { Tripling the area treated } \\
\text { significantly reduced area } \\
\text { burned and led to lower } \\
\text { landscape-level fire } \\
\text { severity. }\end{array}$ \\
\hline
\end{tabular}




\begin{tabular}{|c|c|c|}
\hline $\begin{array}{l}\text { Optimized } \\
\text { Placement }\end{array}$ & $\begin{array}{l}\text { - Performed similarly in } \\
\text { reducing area burned as } \\
\text { distributed placement. } \\
\text { - The RxFire3x scenario } \\
\text { reduced area burned } \\
\text { from BAU, but was not } \\
\text { as effective as } \\
\text { distributing treatments. } \\
\text { Reduced fire severity in } \\
\text { the portion of the } \\
\text { landscape that was } \\
\text { treated, but resulted in } \\
\text { an increase in overall } \\
\text { mean severity. }\end{array}$ & $\begin{array}{l}\text { - Performed similarly in } \\
\text { reducing area burned as } \\
\text { distributed placement } \\
\text { (except RxFire3x). } \\
\text { - RxFire3x significantly } \\
\text { increased area burned as } \\
\text { compared with the RxFire3x } \\
\text { distributed treatment } \\
\text { placement. } \\
\text { Severity was reduced in all } \\
\text { but the optimized RxFire3x } \\
\text { scenario. }\end{array}$ \\
\hline
\end{tabular}

\subsection{Discussion}

Quantifying the effectiveness of fuel treatments can be accomplished at the site level by assessing fire behavior and effects when wildfire burns through a treated stand (Finney 2007, Prichard et al. 2010, Safford et al. 2012) or by modeling potential fire behavior in treated stands (Stephens and Moghaddas 2005). At the landscape level, it becomes challenging to predict how stand-level effectiveness will translate to larger areas, accounting for differences in topography, fuel connectivity or fragmentation, and how those fuels may change through time, as well as limitations in the feasibility of placing fuel treatments everywhere that would benefit. I used a modeling approach to show that fuel reduction through mechanical removal of trees and prescribed fire is effective at reducing fire extent and severity at the landscape-scale, and that spatially optimizing treatments in the areas where fire is more likely to burn at high severity can give similar results to distributing treatments across the entire forested landscape, 
depending on the specific prescription. Similar to what Loudermilk et al. (2014) found in the Lake Tahoe basin, NV and what Syphard et al. (2011b) found in the southern Sierra Nevada, CA, under extreme weather, fuel treatments were especially effective at reducing both severity and area burned due to the greater likelihood of wildfires intersecting treatments prior to fuel re-accumulation.

Regardless of the weather conditions, doubling the amount of prescribed fire on the landscape was not sufficient to improve treatment effects at the landscape scale as compared with the BAU scenario. Tripling today's area treated with prescribed fire, however, significantly reduced annual area burned under both historical and extreme weather and resulted in 50\% more fire-free years than BAU, which implies financial, social, and health benefits for local communities and wildland firefighting agencies. This is a substantial increase in prescribed fire from current management practices, although it falls in line with land management agencies' goals to increase the area treated over time (USDA Forest Service 2012), and expenses incurred through additional focus on prescribed fire would likely be outpaced by the savings associated with the smaller proportion of the landscape burned by wildfire.

While treatment did not significantly reduce landscape-level fire severity under contemporary weather, less of the landscape was subject to burning every year. Similarly, Krofcheck et al. (2017a) found no difference in simulated landscape-scale fire severity between untreated and managed scenarios under contemporary weather in lower-montane mixed-conifer forest in central California, and like this study, they found 
a significant severity reduction under extreme weather with thin-and-burn treatments.

Because the warmer and drier years that precipitate large, severe fires are expected to become more frequent due to ongoing climate change (Littell et al. 2009), it is increasingly critical to manage for more extreme weather instead of looking to past trends when planning the scope of forest management.

The failure of additional prescribed fire to significantly reduce landscape-level severity is not surprising because all management scenarios in this study included at least the amount of prescribed fire currently being applied by land management agencies. Based on other studies, we could expect to see a greater difference between mechanical harvest-only treatments and those with added prescribed fire (Stephens and Moghaddas 2005, Krofcheck et al. 2017a). This does not mean that increasing prescribed fire in small amounts is not beneficial at the site scale - if a wildfire intersects a site treated with prescribed fire within the preceding 10 to 15 years, it is likely to burn with lower severity and may prevent spread to neighboring stands (Fernandes et al. 2004, Finney et al. 2005, 2007). Also, prescribed fire is useful, beyond fuel reduction, for additional ecological purposes, such as wildlife habitat improvement through snag and downed woody debris creation (Stephens et al. 2012, Zarnoch et al. 2014), growth stimulation of understory plants through short-term increases in available nitrogen (Covington and Sackett 1992), modifying forest structure by increasing canopy base height and mean tree diameter through the removal of small diameter trees and ladder fuels (Schwilk et al. 2009), and by favoring fire-maintained species such as trembling 
aspen (Bartos et al. 1994). Therefore, increasing the area treated with prescribed fire is useful at the site level even if extensive increases in area treated are not possible.

Spatial optimization of mechanical treatments is similarly effective at reducing both annual area burned and wildfire severity, as evidenced by the similar performance of the BAU treatment when distributed and optimized under both contemporary and extreme weather. This is consistent with recent studies that found improved performance by treatment placement optimized by simulated fire-travel paths (Finney 2007, Finney et al. 2007) and by likelihood of high severity fire (Krofcheck et al. 2017b). Reductions to area burned and severity were most pronounced under the RxFire $3 x$ scenario, but spatial optimization of this additional prescribed fire was not effective. This appears to be because the reduced area available for treatment also experienced wildfires that removed the same fuel type that was targeted in prescribed fire treatments (i.e., young, small diameter conifer trees). Therefore, the cost-saving benefits associated with spatial optimization of mechanical treatments could be combined with the preventative wildfire management benefits of a larger extent of prescribed fire application to the distributed landscape for a win-win management strategy.

\subsubsection{Effects of fuel treatments in riparian areas}

Although there were no meaningful differences in wildfire activity at the landscape scale when fuel treatments were included in riparian areas, they make up a small proportion of the overall landscape; thus reduction of fire activity in riparian areas 
does not appear extensive enough to be detected at landscape-level averages.

However, this should not be construed to mean that reducing fuels in riparian areas would not have an effect at the site scale. Dwire et al. (2017) reported that crown fire potential in riparian areas in the Blue Mountains is expected to rise, especially for those areas that are dominated by conifers, due to increased water stress under future hotter and drier conditions. Currently hardwood-dominated riparian areas may also experience higher potential for high-severity fire in the future due to species composition shifts toward conifers following dieback of hardwoods such as aspen, which is already being observed and is expected to continue (Swanson et al. 2010, Dwire et al. 2017). Additionally, prescribed fire imparts desirable effects on riparian ecosystems, including impacts to vegetation, macro-invertebrate populations and wildlife habitat quality (Bêche et al. 2005, Arkle and Pilliod 2010), indicating that the site-level benefits may outweigh concerns about management in sensitive riparian areas.

\subsubsection{Limitations}

This study simulated fuel reduction through mechanical harvest and prescribed fire, but did not investigate the differences between wetter-season spring and drierseason fall burning, which can bring about differential effects on vegetation. Spring burns have been found to damage fine roots in ponderosa pine stands (Swezy and Agee 1991), while other studies have found fall burns to consume greater depth of duff, more fine roots, and more of the ectomychorrizal community (Smith et al. 2004), potentially weakening trees and causing increased susceptibility to other stressors such as insects 
and drought. Instead of focusing on the timing of burns, this study used an outcomesbased approach for modeling fuel reduction from prescribed fire by emulating the desired proportion of mortality for species-age cohorts.

As with any study that employs modeling, there are limitations and uncertainty associated with the model. The number of ecological processes that can be included are limited by the model itself and by time limitations. In this case, I employed model extensions to simulate forest succession (seed dispersal, reproduction, growth, competition, age-related mortality), harvest (mechanical tree removal and prescribed fire), and wildfire. I did not include wind disturbance or insect damage, but I included the mortality associated with these disturbances by calibrating the model's simulated background mortality with empirical data and expert consultation (M. Jennings, personal communication, February 14, 2017). Uncertainty is also introduced through the parameterization of the model; for instance, vegetation, temperature, precipitation, and soil characteristics are derived from point sources that have been imputed to a 4-ha resolution, thereby introducing error. However, a study at this scale (approximately 1 million ha) identifies broad spatial and temporal trends and approximations from sitelevel data are sufficient for this purpose.

Stochasticity in modeled disturbance can also introduce uncertainty as interactions between forest succession and disturbance can lead to a range of outcomes over the simulation period. To minimize this uncertainty, I have run 10 replicates of every scenario and reported mean values across replicates. 
Under extreme weather, the greater number of simulated fires, larger annual area burned, and higher fire severity led to more biomass loss over time due to disturbance and less biomass available to be harvested during management events. This was evident across all management prescriptions, but was most evident in precommercial thinning and prescribed fire treatments, both of which target younger cohorts of trees that are most likely to be killed during fire events. This interaction between fire and harvest disturbances likely did not affect wildfire metric outcomes because whether removed by wildfire or by management, reduced biomass and altered fuel types following either simulated disturbance is treated similarly in the model in respect to subsequent fires.

\subsection{Conclusions}

Reducing fuels through mechanical harvest and prescribed fire are effective at reducing annual area burned, fire frequency, and fire severity when applied at the landscape scale over an extended period of time, and these effects are greatest during extreme weather events. During periods with more extreme (i.e., hotter and drier) conditions, fire is more likely to ignite, spread, and escape suppression efforts leading to higher intensity fires with greater severity. At these times, there is also a higher likelihood that fires will intersect with fuel treatments, which contributes to the higher effectiveness of those treatments at reducing wildfire behavior. While there is some uncertainty about the degree to which temperatures will rise and precipitation amounts will change in the future, GCMs consistently project hotter temperatures, a greater 
proportion of precipitation falling as rain rather than snow, earlier snowmelt, and longer fire seasons in the western U.S. Thus, it is critical that land managers plan for an increased incidence of extreme weather conditions and the larger, more intense fires they will facilitate. This study found that spatially optimized mechanical treatments are similarly effective to those distributed throughout the landscape in reducing wildfire spread and severity, which could present opportunities to concentrate management efforts in areas with high likelihood of high-severity wildfires. Increased prescribed fire treatments, which are less expensive and involve less disturbance with heavy equipment and the need for extensive road systems, provide the most benefit when distributed throughout the landscape and as a supplement to current levels of mechanical fuel removal. 


\section{Chapter 4 - Local resident perspectives on forest management and implications for fuel treatments in a rural community in eastern Oregon}

\subsection{Introduction}

As wildfires burn through increasingly large swaths of land in the western United States, generating record costs in terms of fire suppression, destruction of property, and losses of natural resources (Calkin et al. 2005, Westerling et al. 2006, Littell et al. 2009), communities have developed polarized views about how fire and forests should be managed (Gordon et al. 2010). Over the past two decades, social science research into the human dimensions of wildfire has increased, building a picture of the impacts of wildfire on humans and their views on wildfire prevention, suppression, and recovery (McCaffrey et al. 2013) even as an increasing number of people move into fire-prone landscapes (Theobald 2001, Radeloff et al. 2005). While decision-making around forest management practices in public forests rests with land management agencies, public input and collaboration are important steps in developing priorities and strategies. The public has opportunities to review proposed plans and to provide input through public engagement meetings, participation in formal collaborative forestry organizations, or public comment on environmental impact statements (U.S. EPA 2017). For example, in the Blue Mountains of Oregon, U.S.A., the U.S. Forest Service (USFS) is in process of developing the Blue Mountains Forest Resiliency Project to reduce fuel loading and restore dry forest to be more resilient to wildfire. Following the development of a proposed action plan, there was a comment period that elicited 184 comments and 
public engagement meetings that included more than 170 participants (USDA Forest Service 2016a). Comments and discussion were captured and publically posted, and comments were evaluated for inclusion in a refined proposed action plan. The National Environmental Policy Act (NEPA) process will follow with another opportunity for the public to review the environmental impact statement and submit comments.

While this process of public engagement provides an official channel for stakeholders to express their preferences for forest management plans, it has limitations in its usefulness (Brown and Reed 2009). Fuels management presents a "wicked" problem, which cannot be solved objectively because it contains the intersection of ecological science, public policy, and social systems (Rittel and Webber 1973). Public lands are imbued with the values and priorities of all stakeholders, which not only vary across groups and individuals but which change over time. These priorities range from the economic, such as natural resource extraction and tourism, to the highly personal, such as a strong emotional attachment to a particular place or species. Therefore, any question posed by land managers will not have a single correct solution, and instead may have many solutions that are equally satisfying to some portion of stakeholders as they are unsatisfactory to others (Allen and Gould 1986). There is also a limitation in the scope of input agencies can accommodate. Comment periods and public engagement meetings are typically designed to obtain input on a finite project in space and in time, and therefore may not offer a vehicle for utilizing input that is broader in philosophy or that includes requests for operations that would exceed 
project budget, purpose, or a limited timeframe. In forest management, decisions made in the present will have long-term repercussions into the future. For these reasons, McCaffrey et al. (2013) suggest that research is needed to provide insights into how decisions made in the present may affect future forests and communities.

Decision makers have computing tools available to them that go beyond understanding management outcomes at the stand level and the near term. Dynamic forest landscape models (FLMs) integrate complex processes to simulate long-term outcomes at the landscape scale, allowing for scenario building and comparison of alternate strategies. One way to utilize these tools and integrate the input of stakeholders is through public participation geographic information systems (PPGIS). PPGIS is a method of integrating local knowledge into GIS tools by soliciting participation of a group of subjects who contribute to relevant spatial information within the context of a study or project (Schlossberg and Shuford 2005). PPGIS has been used extensively since its inception in the 1990s on wide-ranging topics around public lands such as social values for coastal waters (Strickland-Munro et al. 2015), intersection of social needs and high biodiversity in Palouse Prairies (Donovan et al. 2009), capturing traditional ecological knowledge about fire and fuels (McBride et al. 2017), and forest plan revision in the Chugach National Forest (Brown and Donovan 2013).

\subsubsection{Research objectives}

Through this study, I sought to understand the range of fuel treatment preferences in a rural community that is increasingly impacted by wildfire and to 
identify themes around those preferences through open-ended interviews and focus group discussions. I then investigated the potential for the use of PPGIS as a tool to inform scenario-building to develop alternative community-focused fuel management strategies for use with a dynamic FLM. Forest dynamics and wildfire were simulated over a 90-year period under each scenario, and outcomes were compared among management strategies.

\subsection{Methods}

\subsubsection{Study site}

This study was conducted with members of the communities surrounding the Malheur National Forest in the Blue Mountains of eastern Oregon, U.S.A. Local residents in the Blue Mountains have long relied upon natural resource extraction and utilization for their livelihoods (Shindler and Toman 2003, Hartter et al. 2014), and while most have lived in the region for multiple generations (Shindler and Reed 1996), recent trends are shifting local demographics toward a larger proportion of newcomers (Hamilton et al. 2016). On average, residents are well-informed on local and national forest issues and are well acquainted with the surrounding landscape (Shindler and Toman 2003). Attitudes toward prescribed fire and mechanical fuel treatments are typically positive, with one longitudinal study reporting $89 \%$ and $97 \%$ of survey respondents in support of some amount of each type of treatment respectively (Shindler and Toman 2003). However, individual views on forest management and wildfire risk vary and are influenced by a range of factors such as previous experience 
with wildfire (Hartter et al. 2014), degree of education about forest management, and active engagement with public forest service/education programs (Hartter et al. 2015).

Two collaborative forestry groups operate in the study area and bring multiple stakeholders together to develop recommendations for forest management. The Blue Mountain Forest Partners (BMFP) was established in 2006 and operates out of John Day, Oregon at the northern border of the Malheur National Forest; the Harney County Forest Restoration Collaborative has been operating in the southern portion of the Malheur National Forest since they were founded in 2008. These groups are made up of members from local ranchers, conservation groups, timber companies, environmental law firms, private forest owners, other local residents, and government agencies at local, county, state, federal and tribal levels (Sustainable Northwest 2015, Harney County Restoration Collaborative 2016). Their collaborative focus is on timber stand densities, key wildlife habitats, old growth forest, adjacent private land, and economic values (USDA Forest Service, Malheur National Forest 2015), and the two groups have been credited with creating a collaborative environment in which multiple stakeholders with competing agendas can come together to develop priorities and strategies for forest restoration and management. However, the local community is not unanimous in their support of the collaborative groups just as they are divided in their perceptions of land management agencies. 


\subsubsection{Recruitment}

To answer my research questions, I took a qualitative approach. Data were gathered through questionnaires, focus groups, and individual interviews. Participants were recruited through a variety of nonprobability sampling methods in order to sample across the variation within the local community. Purposive sampling (Kreuger and Neuman 2006) was used to identify members of collaborative forestry groups. This known sample contained members of a range of industries and interests around local forest issues (e.g., owners and employees of local timber companies, cattle ranchers, private forest-owners with land abutting national forest lands). Purposive sampling was supplemented by in-person recruitment at local establishments and through posting recruitment fliers in public places.

Respondents were screened to ensure that they fit the requirements of the study (i.e., adults who reside in the local area and do not currently work for a federal land management agency). From these potential participants, a snowball sample (Goodman 1961, Kreuger and Neuman 2006) was initiated by asking members to identify other community members within their local network. Each of these potential participants was then contacted and asked for additional referrals. However, community members were often reluctant to provide contact information for others, and preferred to forward information about the study to their network to allow potential participants to contact me. In order to ensure anonymity of participants in this small community, no demographic information was collected. 


\subsubsection{Focus groups}

Prior to attending focus groups, participants were asked to complete a questionnaire with ten open-ended questions about their uses of the Malheur National Forest and surrounding areas, what they think about fuel treatments, and how well they believe land management agencies do at incorporating public interests in the management of public lands (Appendix C). Participants were given the option to complete the questionnaire on paper or electronically via online Qualtrics software.

Focus groups were scheduled in the town of John Day, OR between October 25 27, 2016 and in Hines, OR between March 28 - 30, 2017. A total of five focus groups were held. Locations were selected that were not associated with any governmental agency and that had a room large enough to accommodate a group of up to 10 people comfortably. Meetings were audio recorded, and the audio was later transcribed using Start-Stop software. The atlas.ti software (version 7.5.12) was used to code the transcriptions for theme identification.

Meetings began with a short introductory presentation (Appendix C.4), and the focus group discussion proceeded with open-ended questions. To gain a picture of how participants related to the forest, and to help them become comfortable participating in the group discussion, the first question asked was, "What activities do you enjoy in the Malheur National Forest and the surrounding forested areas?" This was followed by additional pre-written questions: 
1. What are your impressions of fuel treatments in general? Light vs.

heavy thinning? Prescribed fire?

2. Are there certain areas on the landscape where you are willing to see fuel treatments? (Identify particular features of the landscape, e.g., hiking trails, wildlife habitat, structures, designated conservation areas, etc...) Are there areas on the landscape where you are not willing to see fuel treatments?

These questions were used to start the conversation and to refocus participants if the discussion strayed far from the topic of fuel management, but discussion was largely allowed to develop organically. After one hour, participants were offered a ten-minute break followed by the PPGIS mapping activity.

\subsubsection{PPGIS}

PPGIS can involve wide distribution of online digital mapping tools to volunteers or a purposive sample of participants where areas of importance are designated by placing points, drawing polygons, or using a digital "spray can," but PPGIS can also be structured as a manual exercise where participants physically draw on maps to indicate values and preferences. The specific questions posed by the study dictate which methodology will be most effective in eliciting the desired data and whether the point or polygon method is most appropriate, as each method introduces spatial error. With the points method, a minimum of 350 participants are needed in order to allow the emergence of spatial patterns, while a study utilizing polygons may be successful with as few as 25 participants (Brown and Pullar 2012). 
The purpose of this study was to combine themes identified through in-depth and open-ended focus group discussion with polygons that designate areas on a large landscape where participants prefer different types of fuel treatment. Because the study landscape is large at just under 1 million ha, and it would be difficult for participants to identify management preferences in very specific locations, polygons were chosen as the appropriate mechanism for spatial identification. Also, this study was designed to facilitate in-depth discussion with a small number of community members to gain rich and detailed information about their preferences for fuel management, and this smaller number of participants is appropriate for polygon use.

A detailed map of the study area was divided into four quadrants, which were printed on 39 " $\times 39$ " posters and hung on the walls around the focus group participants. Sheets of clear mylar plastic were taped on top of them so that participants could draw polygons directly onto the plastic. Colored permanent markers were used to indicate willingness to see light thinning, heavy thinning, or prescribed fire spatially on the landscape or to indicate a lack of willingness (Figure 4.1). Participants were encouraged to discuss their choices and work together to reach consensus about polygon placement. I noted where agreement occurred and where participants disagreed. See Appendix C.4 for all four quadrant maps and Appendix C.5 for the color code chart.

\subsubsection{Interviews}

Three interviews were conducted. Two of these were with community members who wanted to participate but who were unable to attend any scheduled focus group. 
One was via phone and one was in person. The third was with the sole attendee of one focus group where the other scheduled participants were not able to attend at the last minute. Interviewees were asked the same questions as focus group participants and also allowed to direct the conversation organically. However, they were not given the PPGIS mapping activity.

\subsubsection{Scenario development and landscape simulations}

Utilizing the themes that emerged through focus group discussions, interviews, and questionnaires and the spatial information from the PPGIS activity, I developed three alternative management scenarios that represented the range of fuel management preferences identified by participants. While not every viewpoint could be included, my aim was to capture the upper and lower limits of participants' preferences while accounting for the spatial themes identified through discussion and the mapping activity. To compare these community-derived strategies with current management, I leveraged forest management scenario development from previous research (Chapter 2).

Changes in forest and fuel bed characteristics over time were simulated with the dynamic landscape forest model LANDIS-II (Scheller et al. 2007), which is widely used to simulate forest succession and interactions with disturbances such as fire, harvest, wind, and insects (Scheller et al. 2008, Lucash et al. 2014, Duveneck et al. 2014, Kretchun et al. 2014, 2016, Lucash et al. 2017, Loudermilk et al. 2017). LANDIS-II uses the life history traits of tree and shrub species, along with soil and climate data, to simulate 
successional trajectories and responses to disturbances over time. Trees are simulated as species-age cohorts, which represent all individual trees of each species as a single group within an age range (e.g., for this study trees were grouped into 10 -year age cohorts). Each cell represents a simulation site on the landscape of $200 \times 200$ meters (4 ha), in which all forested vegetation and topographical conditions are assumed to be homogeneous. Sites can be active or inactive, such as in the case of open water or rocky outcroppings where vegetation is not expected to exist. Processes, such as reproduction, competition, growth, disturbance, and mortality, are simulated both within and between sites (see Chapter 2, Figure 2.4). LANDIS-II v6.2 was used with the Net Ecosystem Carbon and Nitrogen (NECN) succession (v4.2) and the Dynamic Fire and Fuels System (v4.0) extensions with outputs including biomass of individual species (i.e., species-age cohorts), fuel types, and fire severity for each individual cell on the landscape. The Biomass Harvest (v3.2) extension simulated tree harvest in the southern portions of the Malheur and Wallowa-Whitman National Forests and surrounding forested landscape. Harvested biomass, wildfire activity (annual area burned and fire severity) and forest types were compared among scenarios.

To capture the variability within model runs related to forest and disturbance dynamics, I ran ten replicates of each simulation and report averages and standard deviation among replicates. Because greenhouse gas emissions continue to exceed the Intergovernmental Panel on Climate Change worst case scenarios, indicating that high emissions are likely to continue in the absence of a radical solution (Jennings 2013, 
Pachauri et al. 2014), all simulations were run with daily weather conditions from high emission relative concentration pathway (RCP) 8.5 climate conditions using ten different RCP 8.5 global circulation models (GCMs; see Chapter 2 for a description of GCM selection). To assess differences among treatment scenarios, annual biomass harvested, annual area burned, and mean fire severity were compared. Biomass harvested included timber removed in commercial harvest, small-diameter wood removed during precommercial thinning, and biomass combusted through prescribed burning. Annual area burned is log-normally distributed and so was transformed by the natural log. Mean severity is output by the Dynamic Fire and Fuels System, and is the mean severity value across all sites that burn within a single fire. This value is an index that indicates the expected fraction of the forest crown that will be burned based on the fire's intensity (rate of spread), moisture levels (foliar moisture), and forest structure (crown base height). The severity index ranges from 1 (<10\% crown fraction burned) to 5 (>90\% crown fraction burned).

\subsection{Results and Discussion}

\subsubsection{Participants}

The total number of community participants was 23: three participated in individual interviews and 20 in focus groups. Out of this total, 16 also submitted responses to the questionnaire. Participants reported using the forest in primarily recreational ways (e.g., camping, hiking, physical exercise) and ways related to the timber industry, followed by personal use of natural resources including hunting, fishing, 
firewood gathering, and mushroom foraging. Cattle grazing was also common (Figure

\section{1). Participants expressed a wide range of views pertaining to fuel treatment}

preferences, and data saturation (Morse et al. 2014) was reached by the final focus

group wherein no additional themes emerged.

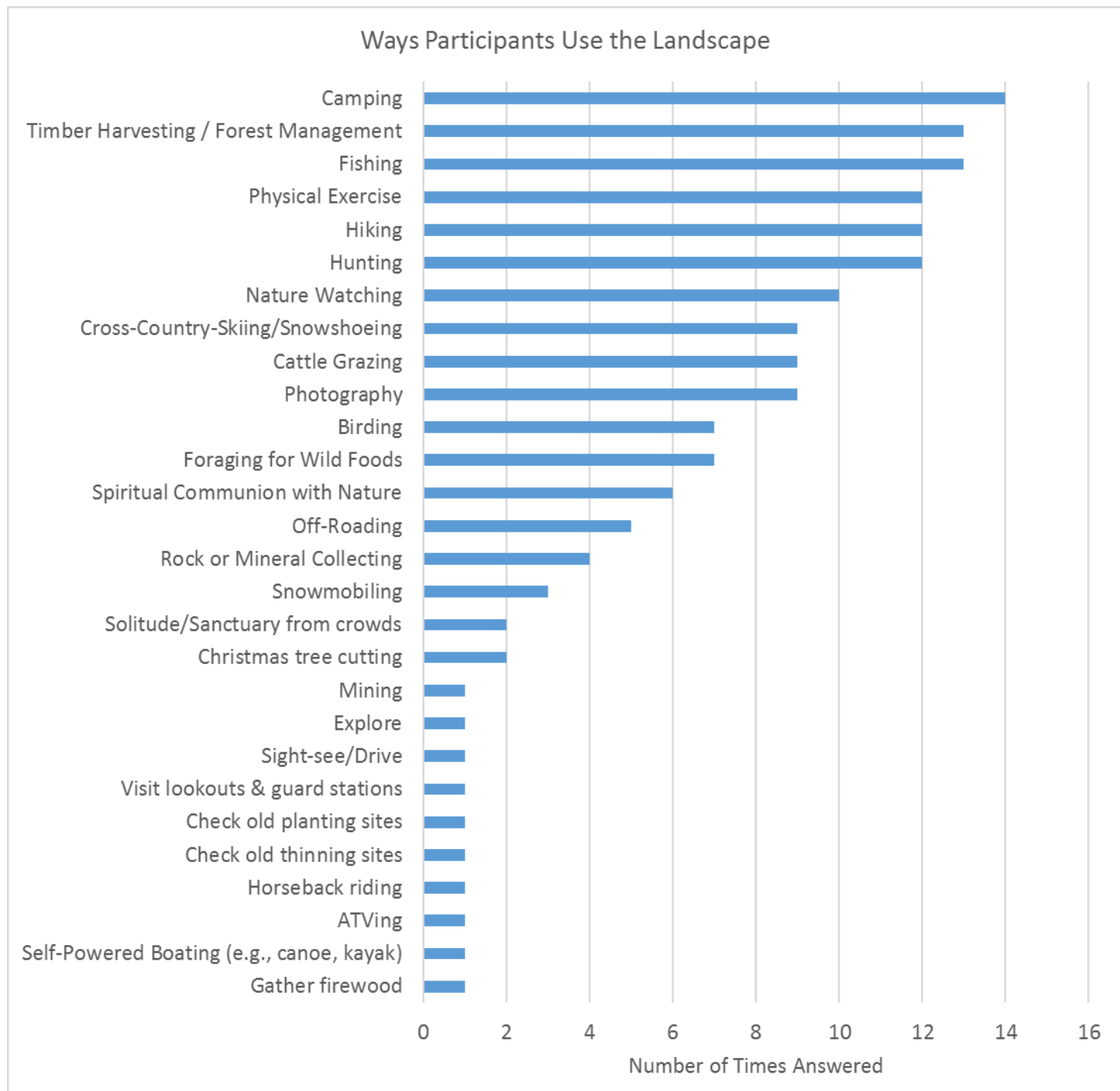

Figure 4.1. Participants' questionnaire responses to the question, "What activities do you enjoy in the Malheur National Forest and the surrounding forested areas?" The most common answer, made by 14 out of 16 questionnaire respondents, was camping. Although only one respondent included firewood gathering, several focus group participants discussed firewood gathering as an activity they consider enjoyable and pursue for financial savings. 


\subsubsection{Emergent themes}

Through focus group discussion and interviews, participants expressed views that linked fuel treatments to a range of topics. Discussions wove together perceptions of forest management, ecosystem health, and wildlife habitat with trust in government, economic struggles, and polarization of the local population's political views. One participant summed up what he saw as the community's overall priorities: "...there's only 3 things. One is, what do the people want off the forest? Well they want jobs. Two, they want a place to recreate. And three, they don't want their house to burn down." But delving into how they prefer to have those needs fulfilled revealed a complex network of topics that shaped participants' worldviews and consequently their views on how the forest should be managed.

Through fuel treatment discussions, along with answers to the questionnaires, seven primary themes emerged. These themes were subdivided into 35 sub-themes (Table 4.1), each of which were discussed in at least two focus groups or interviews.

Table 4.1. Emergent themes from focus group discussions, interviews and questionnaires. Each theme is divided into sub-themes and salient quotes are included for each theme.

\begin{tabular}{|c|c|c|}
\hline Theme & Sub-Themes & Salient Quotes \\
\hline Institutions & $\begin{array}{l}\text { - Trust } \\
\text { - Collaborative forestry } \\
\text { groups } \\
\text { - Public input } \\
\text { - Litigation } \\
\text { - Government overreach }\end{array}$ & $\begin{array}{l}\text { "They do not accept any public interests. } \\
\text { They merely hold meetings that are } \\
\text { convenient for them... then tell lie[s] about } \\
\text { what was said." } \\
\text { "I personally don't know how much more } \\
\text { public outreach that we expect from a } \\
\text { federal agency... We have a collaborative } \\
\text { group that's nationally recognized. } \\
\text { Anybody can participate in it." }\end{array}$ \\
\hline
\end{tabular}




\begin{tabular}{|c|c|c|}
\hline Decision Making & $\begin{array}{l}\text { - Local control } \\
\text { - Expert opinion }\end{array}$ & $\begin{array}{l}\text { "I believe the local people should be in } \\
\text { total control of the public lands." } \\
\text { "The public should hire professional } \\
\text { foresters, then let them work." }\end{array}$ \\
\hline $\begin{array}{l}\text { Ecology / Forest } \\
\text { Health }\end{array}$ & $\begin{array}{l}\text { - Old growth } \\
\text { - } 21^{\prime \prime} \text { cut limit } \\
\text { - Wildlife habitat } \\
\text { - Aspen decline } \\
\text { - Bark beetles/pests } \\
\text { - Climate change } \\
\text { - Meadows/conifer } \\
\text { - } \text { encroachment } \\
\text { - Histure generations } \\
\text { - Hical conditions }\end{array}$ & $\begin{array}{l}\text { "...it's hard to talk about this landscape } \\
\text { and not talk about managing for } \\
\text { populations and managing for other } \\
\text { things because when I think of } \\
\text { management... I think about refuge for } \\
\text { animals, how to keep our whole } \\
\text { ecosystem healthy." } \\
\text { "There are good reasons to have those big } \\
\text { trees around. So you have to decide when } \\
\text { and where you want them... big trees in } \\
\text { aspen stands, the ones that were sucking } \\
\text { all the water out... you have to decide if I } \\
\text { want aspen or do I want a big tree." }\end{array}$ \\
\hline $\begin{array}{l}\text { Wildfire } \\
\text { Perceptions }\end{array}$ & $\begin{array}{l}\text { - Fear of fire } \\
\text { - Smoke } \\
\text { - Naturalness / } \\
\text { inevitability of fire } \\
\text { - Escaped prescribed fire } \\
\text { - Insufficient fire-fighting } \\
\text { - Canyon Creek Complex } \\
\text { of } 2015\end{array}$ & $\begin{array}{l}\text { "I don't have a problem with smoke... } \\
\text { you're either going to get it when the } \\
\text { forest burns, [or] you're going to get it } \\
\text { with the prescribed fire." } \\
\text { "Then entered Smokey the Bear, and the } \\
\text { ecosystem started to change. Mother } \\
\text { Nature doesn't sit still. We excluded fire, } \\
\text { so things are changing. To just let Mother } \\
\text { Nature take its course now, we will lose } \\
\text { everything that we enjoy up in the forest." }\end{array}$ \\
\hline Economics & $\begin{array}{l}\text { - Timber industry } \\
\text { - Local unemployment / } \\
\text { jobs } \\
\text { - Insufficient budget } \\
\text { - Mills }\end{array}$ & $\begin{array}{l}\text { "You can't blame the environmentalists. } \\
\text { We didn't like the looks of it either. But } \\
\text { everyone got rated on how well they got } \\
\text { the cut out. Congress mandated it, and } \\
\text { they didn't know anything about } \\
\text { managing forests. All they wanted to do } \\
\text { was stimulate the economy. So that's why } \\
\text { we're paying for it the way we are today." } \\
\text { "The kids are growing up, leaving and not } \\
\text { coming back. The economy is gone, and I } \\
\text { attribute it mostly because the mill is }\end{array}$ \\
\hline
\end{tabular}




\begin{tabular}{|c|c|c|}
\hline & & $\begin{array}{l}\text { gone. There used to be a decent wage } \\
\text { living if you could grow up and go to work } \\
\text { in the mills and provide for a family... and } \\
\text { now, the only thing around here that will } \\
\text { give you that kind of wage is a } \\
\text { government job. Some of us are tired of } \\
\text { paying all those people's wages and } \\
\text { seeing all the great benefits they get. The } \\
\text { rest of us are straining to keep the families } \\
\text { fed. So it's a loss of local economy while } \\
\text { were not harvesting." }\end{array}$ \\
\hline $\begin{array}{l}\text { Forest } \\
\text { management }\end{array}$ & $\begin{array}{l}\text { - Right treatment, right } \\
\text { place } \\
\text { - Off-limits areas } \\
\text { - Manage to prevent fire } \\
\text { - Multiple use } \\
\text { - Protect homes and } \\
\text { infrastructure } \\
\text { - Accelerated } \\
\text { management }\end{array}$ & $\begin{array}{l}\text { "I don't think the question is when and } \\
\text { where on the land do you think fuel } \\
\text { treatment ought to occur. It's not about } \\
\text { heavy or light treatment. It's what's } \\
\text { appropriate for that site at this point in } \\
\text { time." } \\
\text { "I can't think of a single forested } \\
\text { community that shouldn't be thinned or } \\
\text { burned at some point, in some way." }\end{array}$ \\
\hline Political climate & $\begin{array}{l}\text { - Polarized views / } \\
\text { community } \\
\text { fragmentation } \\
\text { - Occupation of Malheur } \\
\text { Wildlife Refuge } \\
\text { - Perceptions about } \\
\text { what other people in } \\
\text { the community think }\end{array}$ & $\begin{array}{l}\text { "...the time that I've been here I can feel } \\
\text { the political climate is changing very } \\
\text { rapidly here, and it's having a negative } \\
\text { effect on the people who live here from my } \\
\text { perspective. You know, the scare of big } \\
\text { government coming..." } \\
\text { "It's a real polarizing topic. Nobody wants } \\
\text { to talk about forest management and } \\
\text { wildfires. People are so integrated in this } \\
\text { community and have family in the forest } \\
\text { service or strictly industry people who hate } \\
\text { the Forest Service and were raised to hate } \\
\text { the Forest Service. And especially in our } \\
\text { political climate right now everyone is } \\
\text { polarizing. No one wants to talk about it." }\end{array}$ \\
\hline
\end{tabular}

Many of these themes are consistent with results of a longitudinal study conducted in the Blue Mountains in 1996 and 2000 to determine public perceptions of fuel treatments including mechanical tree removal and prescribed burning (Shindler and 
Reed 1996, Shindler and Toman 2003). They found that among subjects who were randomly selected to complete a mailed survey, "prescribed fire and mechanical thinning appear[ed] to be useful and acceptable practices to most of the public" during the first stage (Shindler and Reed 1996), and that high levels of approval remained similar through the second stage, although levels of trust in the USFS had diminished and concern about smoke from prescribed fire had increased (Shindler and Toman 2003). Smoke from prescribed fire remains a concern, however, most participants expressed that they themselves were not worried about smoke.

Another concern was that a restoration and fuels management perspective that restricts cutting old trees will be problematic to forest health in the long run. This theme was repeated in several meetings, in some cases with nearly identical language. One participant put it this way:

"If you took the human race and killed everybody under the age of 60, within 30 years, the human race would be completely gone. That's what they are doing with the forests in my opinion. You're killing all these small trees that are the trees that should be sustaining the forest and growing, and leaving all these great big pine that are so called 150 year old trees that were flat top, dead top, whatever they may be. They are leaving them standing, and all they do, they're cutting everything around it. Well when those big trees don't have protection, they either blow over, or they die from bugs or disease, or die from old age. In my opinion, they are doing it totally backwards. You need to harvest. I'm not saying cut every big tree on the forest, and I'm not saying clear cut because I don't believe in that either. But you need to have a balance. You need to cut the big trees and you need to cut the smaller trees."

This concern was common with participants who also tended to favor eliminating upper size limits for cutting, who expressed concern about economic 
downturns in the community related to lack of work, and who expressed a lack of trust in federal agencies. However, participants agreed that they did not prefer to have clearcut harvesting employed. Even participants who preferred to see large trees harvested for their economic value expressed a desire for some large, old trees to be left and for harvest to follow a multi-aged format wherein stands have only a portion of trees harvested in any given year and a range of ages are left to mature for later harvest and as seed source for natural regeneration.

\subsubsection{Spatial themes}

The primary response to the question of where treatments should be placed was that they should be placed where "appropriate," regardless of administrative restrictions. There is consensus among community members that appropriate placement is something that should be determined by "experts," but there is disagreement about who the experts are - whether they are federal fuels managers and silviculturists or current/former timber industry professionals and other local residents. One interpretation of appropriate placement was that treatments should be concentrated around homes: "... we need to be treating next to where people live. And that should be the only place we're treating until we get that all treated." Several other participants suggested that areas that are currently off-limits to most treatment, such as designated wilderness, roadless areas, and riparian buffer zones, should not be excluded from treatment up to and including some commercial harvest. On the other extreme 
was the view that protected areas should never be treated, regardless of fuels loadings or other forest health issues in favor of letting "...Mother Nature take her course." A number of participants expressed a preference for prescribed fire and/or heavy thinning to be used in dry forest, while light thinning was preferred in moist forest at higher elevations and on north-facing slopes. Nearly all participants, regardless of their overall fuel treatment philosophies, expressed their desire for treatment areas to be determined by need on a case-by-case basis. It was common for participants to avoid drawing polygons on the maps in favor of using the maps as a way to illustrate and discuss their overall spatial outlook. Polygons that were drawn tended to encompass large areas of the landscape, however they were still effective in identifying spatial themes for scenario development (Figure 4.2). 


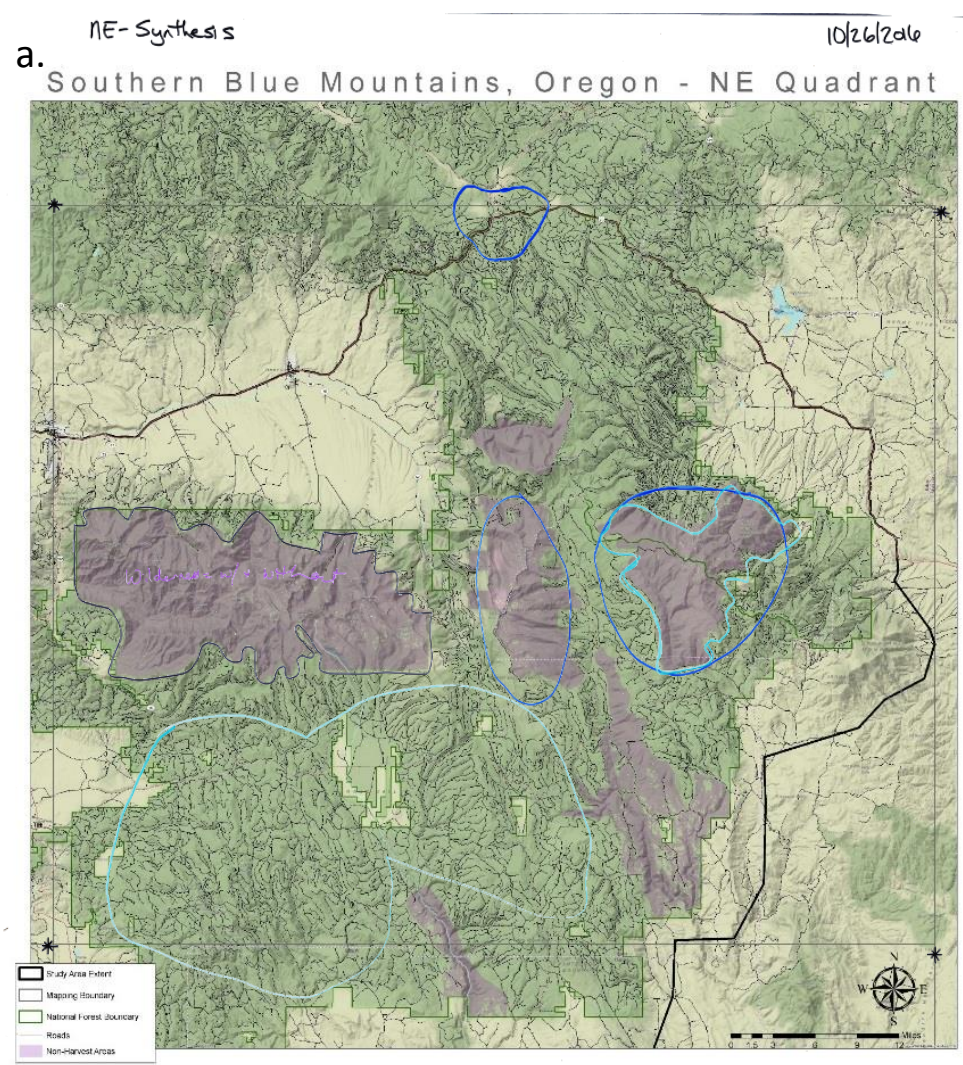

Syatheis
b. Southern BI $128 / 2017$

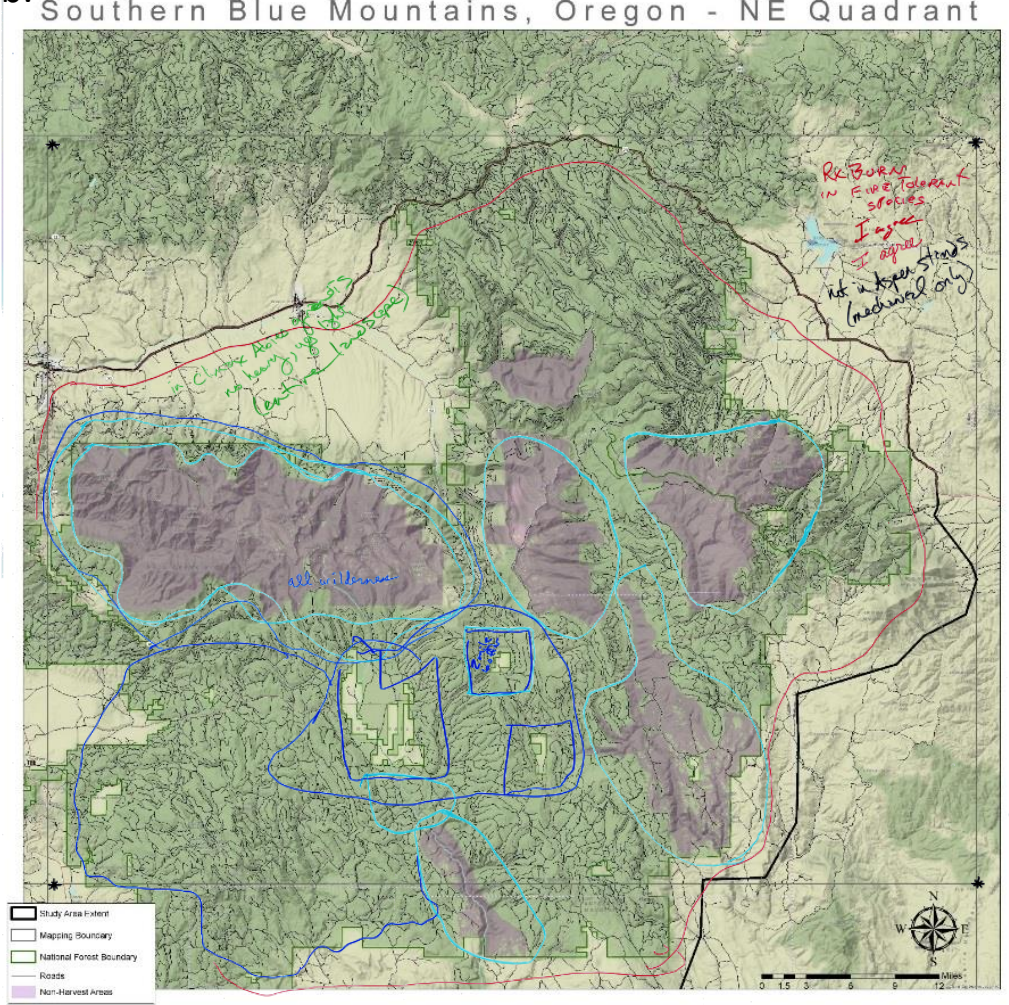


Figure 4.2. Participatory mapping examples. Dark green areas are national forest, light green are privately owned, and purple are areas restricted from management (e.g., designated wilderness and roadless areas). Solid black line indicates the study area boundary. These two overlays depict participatory mapping from two separate focus groups for the northeastern quadrant of the study landscape. Participants expressed difficulty identifying specific areas on the landscape where they had fuel treatment preferences, but were able to use the maps to illustrate their thematic preferences. Most groups were able to obtain consensus, but preferences about management in wilderness areas were the most divisive. Preferences in wilderness areas ranged, even within single group, from no treatment to commercial harvest (a.) Many participants expressed a willingness to see light thinning (e.g., pre-commercial thinning) and prescribed fire on most areas of the landscape, including wilderness areas for areas with high fuel loading (b.), and many were open to any kind of treatment anywhere on the landscape if it was deemed appropriate for meeting ecological, fire management, and/or economic goals.

\subsubsection{Management scenario development}

From these topical and spatial themes, I developed two management scenarios that present the range of values and preferences expressed by participants, which are titled the Restoration and Economic scenarios. These scenarios were compared with a scenario designed to emulate current management practices called Business As Usual (BAU). (See Chapter 2 for a description of the BAU management scenario.)

The Restoration scenario focuses on improving forest resilience to fire without any commercial harvest by reducing small-diameter horizontal and vertical fuel loadings. An approximately equal area was treated as with the BAU scenario, but only pre-commercial thinning (PCT) and prescribed fire (RxFire) were employed. In the national forest, $9 \%$ of non-restricted forested area was treated with PCT every decade and RxFire was applied to 3\% of forested area. Bureau of Land Management and Oregon Department of Forestry-managed lands were treated with PCT on 7\% of their forested 
lands per decade. No treatments were done in riparian areas or wilderness/roadless areas. Private timber remains as described in BAU.

The Economic scenario was designed to emulate short-rotation multi-aged stand management (O'Hara 2005) on a 50-year rotation. Although clearcutting and re-planting was the predominant silvicultural system employed through the early 1980s (Youngblood 2005), I did not include clearcutting in this scenario because focus group participants expressed a preference for uneven-aged management with overstory removal of the largest and most economically valuable trees. They also expressed the desire for some old trees to be left, so 10 of the oldest age cohorts were left unharvested for wildlife habitat, old forest structure, and social enjoyment. Although individual trees of Engelmann spruce, whitebark pine, or subalpine fir may be harvested commercially, it is unlikely that logging companies would remove entire cohorts of these species, so these species were left unharvested in simulations. Many participants expressed a desire to see light fuel treatments in areas with high fuel loads including areas that are currently off-limits, so I included pre-commercial thinning, prioritized by dense fuelbeds of small diameter trees and shrubs, in the federal landscape at large, in riparian areas, and in wilderness and roadless areas. No RxFire was included, however, as many participants who were interested in an economically-driven harvest model expressed feeling that prescribed fire wastes natural resources by consuming wood they would prefer see used for non-timber wood products. Even participants who wanted to open up wilderness areas to harvest tended to express an appreciation for the 
"untouched" feeling of those areas and did not advocate for aggressive harvest there.

Therefore, I set decadal harvest to just $5 \%$ of wilderness/roadless areas with another $5 \%$

being treated to reduce fuels. Because of concerns about fuels and conifer

encroachment in riparian areas, I assigned $10 \%$ of riparian areas to be pre-commercial

thinned and another $10 \%$ to be open for commercial harvest.

Table 4.2. Harvest scenario descriptions. Restoration and Economic scenarios were designed using data gathered during focus groups with community members. The Business as Usual (BAU) scenario reflects pre-commercial thinning (PCT), harvest, and prescribed fire (RxFire) prescriptions currently employed by land management agencies. Annual area harvested/burned includes all management areas including privately owned and reflects the first decade of simulated treatments averaged over ten replicates. Over time, the area fluctuated with the availability of suitable forest composition and age due to prior harvest and wildfire mortality. RxFire area includes burning of previously harvested stands ten years after harvest (BAU and Restoration scenarios only).

\begin{tabular}{|c|c|c|c|}
\hline Scenario & Prescription Goals & Off-Limit Areas & $\begin{array}{l}\text { Annual Area } \\
\text { Harvested/RxFire per } \\
\text { Decade }\end{array}$ \\
\hline Restoration & $\begin{array}{l}\text { - Focus on improving } \\
\text { forest resilience to } \\
\text { wildfire through fuels } \\
\text { reduction and } \\
\text { restoration of an older } \\
\text { stand structure. } \\
\text { - No commercial harvest. }\end{array}$ & $\begin{array}{l}\text { - Wilderness } \\
\text { - Roadless Areas } \\
\text { - Riparian Habitat } \\
\text { Conservation } \\
\text { Areas }\end{array}$ & $\begin{array}{l}\text { PCT: } 35196 \text { ha } \\
\text { Harvested: } 7,214 \text { ha } \\
\text { (on private lands only) } \\
\text { RxFire: } 48,420 \text { ha }\end{array}$ \\
\hline $\begin{array}{l}\text { Business as } \\
\text { Usual }\end{array}$ & $\begin{array}{l}\text { - Improving forest } \\
\text { resilience to wildfire by } \\
\text { reducing fuels and } \\
\text { managing for } \\
\text { ponderosa pine is the } \\
\text { primary goal. } \\
\text { - Commercial harvest is a } \\
\text { secondary goal. } \\
\text { - No harvest of trees } \\
\text { over } 21 \text { " DBH. }\end{array}$ & $\begin{array}{l}\text { - Wilderness } \\
\text { - Roadless Areas } \\
\text { - Riparian Habitat } \\
\text { Conservation } \\
\text { Areas }\end{array}$ & $\begin{array}{l}\text { PCT: } 13,296 \text { ha } \\
\text { Harvested: } 55,351 \text { ha } \\
\text { RxFire: } 39,391 \text { ha }\end{array}$ \\
\hline
\end{tabular}




\begin{tabular}{|c|c|c|c|}
\hline Economic & $\begin{array}{l}\text { - Short-rotation, multi- } \\
\text { aged commercial } \\
\text { harvest. } \\
\text { - Harvest large, valuable } \\
\text { trees of commercially } \\
\text { viable species. } \\
\text { - No limit to tree size } \\
\text { that can be harvested. }\end{array}$ & - None & $\begin{array}{l}\text { PCT: } 21,890 \text { ha } \\
\text { Harvested: } 116,584 \text { ha } \\
\text { RxFire: } 0 \text { ha }\end{array}$ \\
\hline
\end{tabular}

\subsubsection{Simulation results}

Under the Economic scenario, more than three times the amount of biomass was harvested than under the BAU scenario and more than six times that of the Restoration scenario (Figure 4.3). Despite removing higher levels of biomass and harvesting about 50,000 ha more per decade, this did not translate to reduced fire risk. Although the Economic scenario included some pre-commercial thinning, most biomass that was targeted for harvest was from older age-cohorts and therefore its removal had less impact on shifting distributions of annual area burned or wildfire severity than removal of the smaller diameter, more flammable biomass targeted for fuels treatment in the Restoration scenario. While there was no statistically significant difference in area burned or wildfire severity among treatment types, the Restoration scenario produced consistently lower area burned than the other two scenarios (Figure 4.4a) and had lower mean area burned during the last 30 years of the century (Figure $4.4 \mathrm{~b}$ ). This was also true for wildfire severity, with the lowest mean severity under the Restoration scenario and the highest under the Economic scenario (Figure 4.5). 


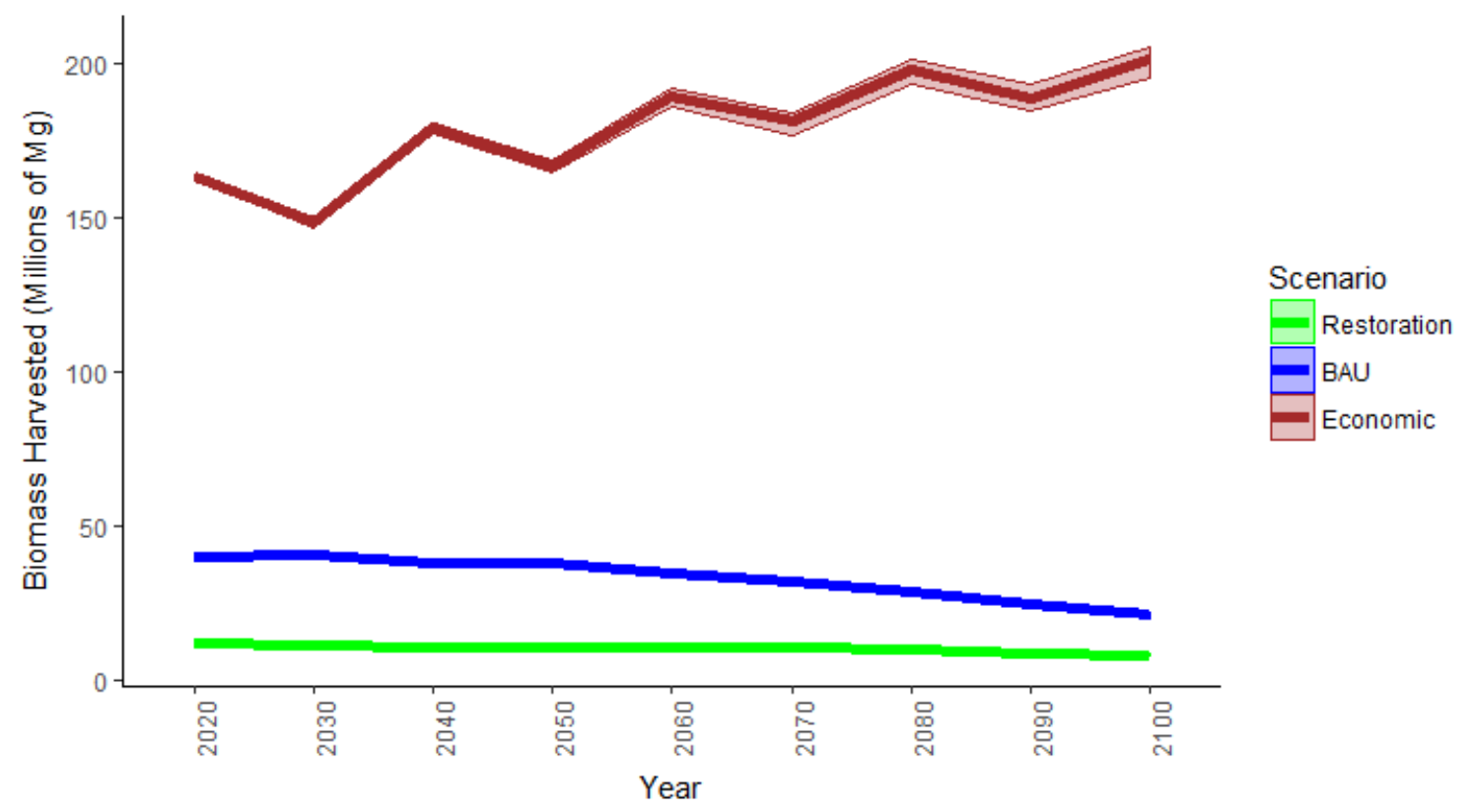

Figure 4.3. Average annual biomass harvested over time for each of the fuel treatment/harvest scenarios. Solid lines show the mean and the ribbon reflects the $5^{\text {th }}$ and $95^{\text {th }}$ percentile across replicates. Harvested biomass amounts were dependent upon the amount of biomass available in the designated species-age cohorts for each scenario's prescriptions. The Restoration scenario removed only young cohorts of trees through pre-commercial thinning and prescribed fire for the purpose of reducing fuel loading. The Business as Usual scenario (BAU) included a combination of commercial harvest with pre-commercial thinning and prescribed fire at approximately a 100 -year rotation. The Economic scenario was designed to commercially harvest the landscape on a 50-year rotation and maintain a multi-aged stand structure. It also included a small amount of pre-commercial thinning for areas with the highest fuel loadings, but did not include any prescribed fire. Biomass amounts are summed across all harvest events over each decade and are shown in millions of megagrams. 

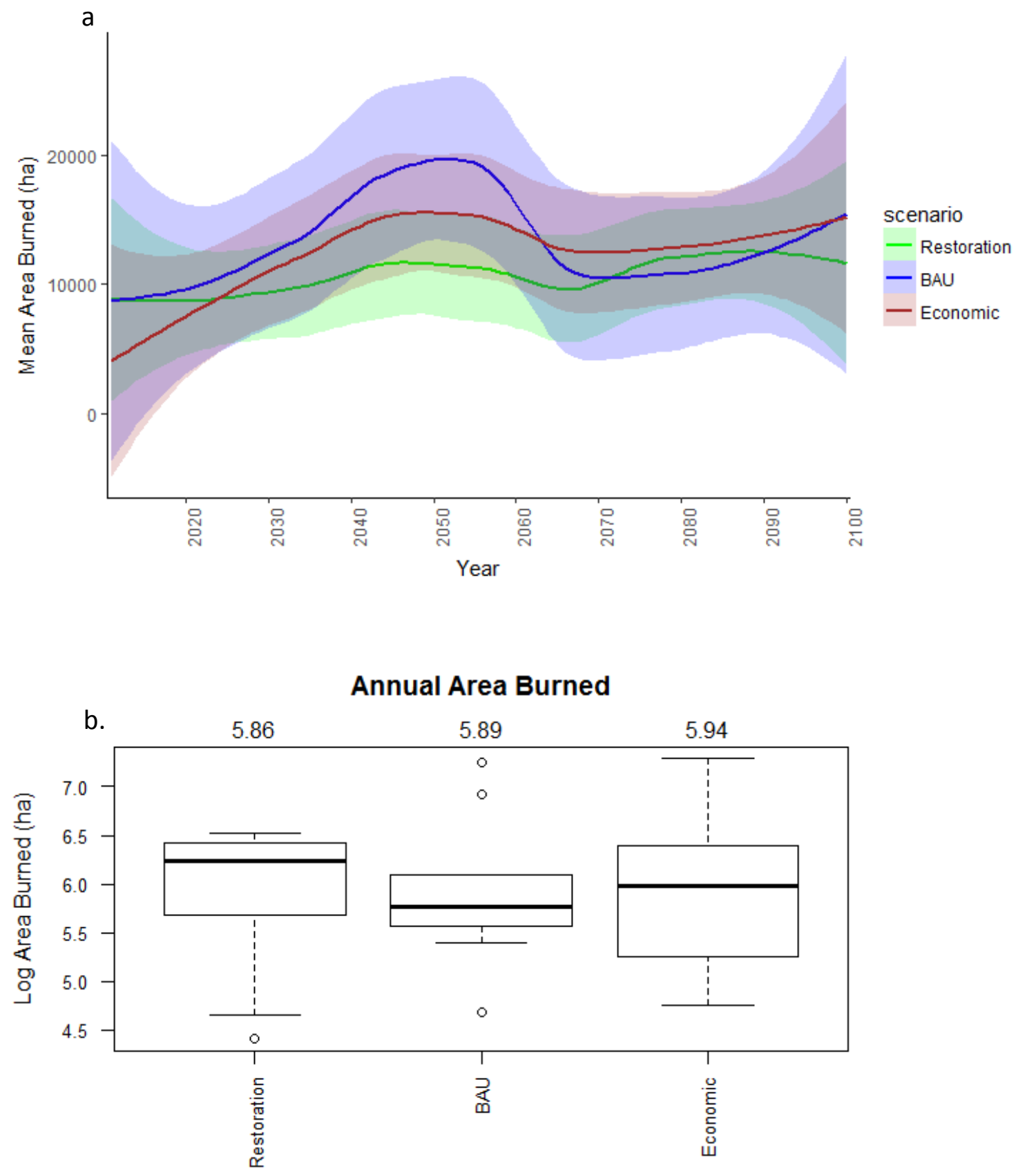

Figure 4.4. Annual area burned under each treatment/harvest scenario. Over the 90-year simulation period (a.) mean area burned increased for the first half of the century under all harvest scenarios with the greatest increases under Business and Usual and the least under Restoration. Area burned under the Restoration scenario, which focused on fuels reduction, was the most consistent. During the latter half of the century, area burned increased slightly under Restoration and decreased under the more aggressive harvest scenarios. Solid lines indicate the running mean with a loess smoothing curve. During the last 30 years (b.) there was no 
significant difference in mean annual area burned $(F=0.03, p=0.97)$. For the boxplot, area burned data are transformed by the natural log. Boxes encompass the $25^{\text {th }}$ and $75^{\text {th }}$ percentiles, whiskers extend to 1.5 times the interquartile range, and circles indicate outliers. Solid line is the median, and mean values are reported at the top of each box.

\section{Fire Severity}

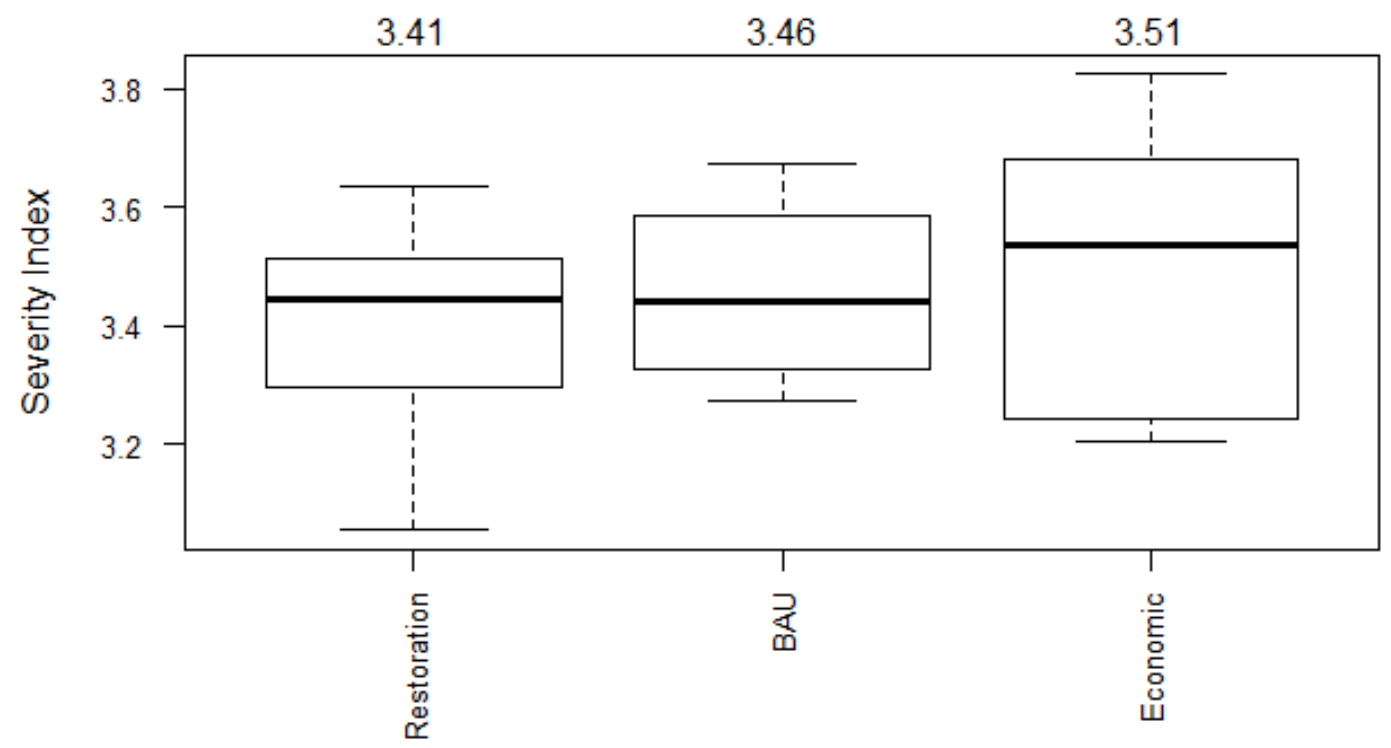

Figure 4.5. Mean fire severity for the final 30 years of landscape simulations (2070 - 2100). There was no significant difference in fire severity regardless of the fuel treatment/harvest scenario $(F=0.796, p=0.46)$, although the Economic scenario had the greatest variability. The Restoration treatment's upper range was similar to Business as Usual, but the lower range illustrates the potential benefit that increased amounts of prescribed fire may indicate for reducing landscape-level fire severity. Boxes encompass the $25^{\text {th }}$ and $75^{\text {th }}$ quartiles and the whiskers extend to 1.5 times the interquartile range. Solid line is the median, and mean values are reported at the top of each box. 
Table 4.3. Wildfire metrics for the last 30 years of simulations (2071-2100). Values reflect the mean and standard deviation (in parentheses) across 10 replicates for each scenario. Mean fire severity is reported on a scale of 1 ( $0 \%$ potential mortality) to 5 ( $100 \%$ potential mortality) for all sites that burned during that period. There was no statistical difference in mean severity $(F=$ $0.796, p=0.46)$ or annual area burned $(F=0.028, p=0.97)$ among treatment scenarios.

\begin{tabular}{|c|c|c|}
\hline Scenario & Mean Fire Severity & Annual Area Burned (ha) \\
\hline Restoration & $3.41(0.18)$ & $12,709(36,753)$ \\
\hline BAU & $3.46(0.15)$ & $12,768(50,626)$ \\
\hline Economic & $3.51(0.23)$ & $13,202(42,212)$ \\
\hline
\end{tabular}

Nearly all participants expressed a desire for forest management to promote "healthy" forests. When asked for more details, in addition to fire-safe forests, many of them listed their perspectives on health to include diverse forests and a variety of forest patches, maintaining sensitive tree species such as aspen and whitebark pine, quality habitat for wildlife species, especially species associated with fishing and hunting, and maintaining a "natural" forest in wilderness areas. While many of these goals were outside the scope of this study's simulation capability, I assessed the effect of each management scenario on the persistence of high-elevation forest. The results from Chapter 2 show steep declines in high-elevation species including Engelmann spruce, whitebark pine, and sub-alpine fir under all climate scenarios. Under the high emissions scenario, biomass of these three species dropped nearly $50 \%$ in the first three decades.

While none of the management strategies prevented high-elevation forest loss, the Restoration scenario performed the best in terms of prolonging persistence on the landscape at the 30-year mark (Figure 4.6). By the end of the century, area with high- 
elevation forest had declined by about $90 \%$ for all management scenarios, with the greatest losses in the BAU scenario (Figure 4.7). Biomass reductions for these species were associated with repeated burns, especially on steep slopes, which is accounted for by the lower area burned and fire severity under the Restoration scenario. 

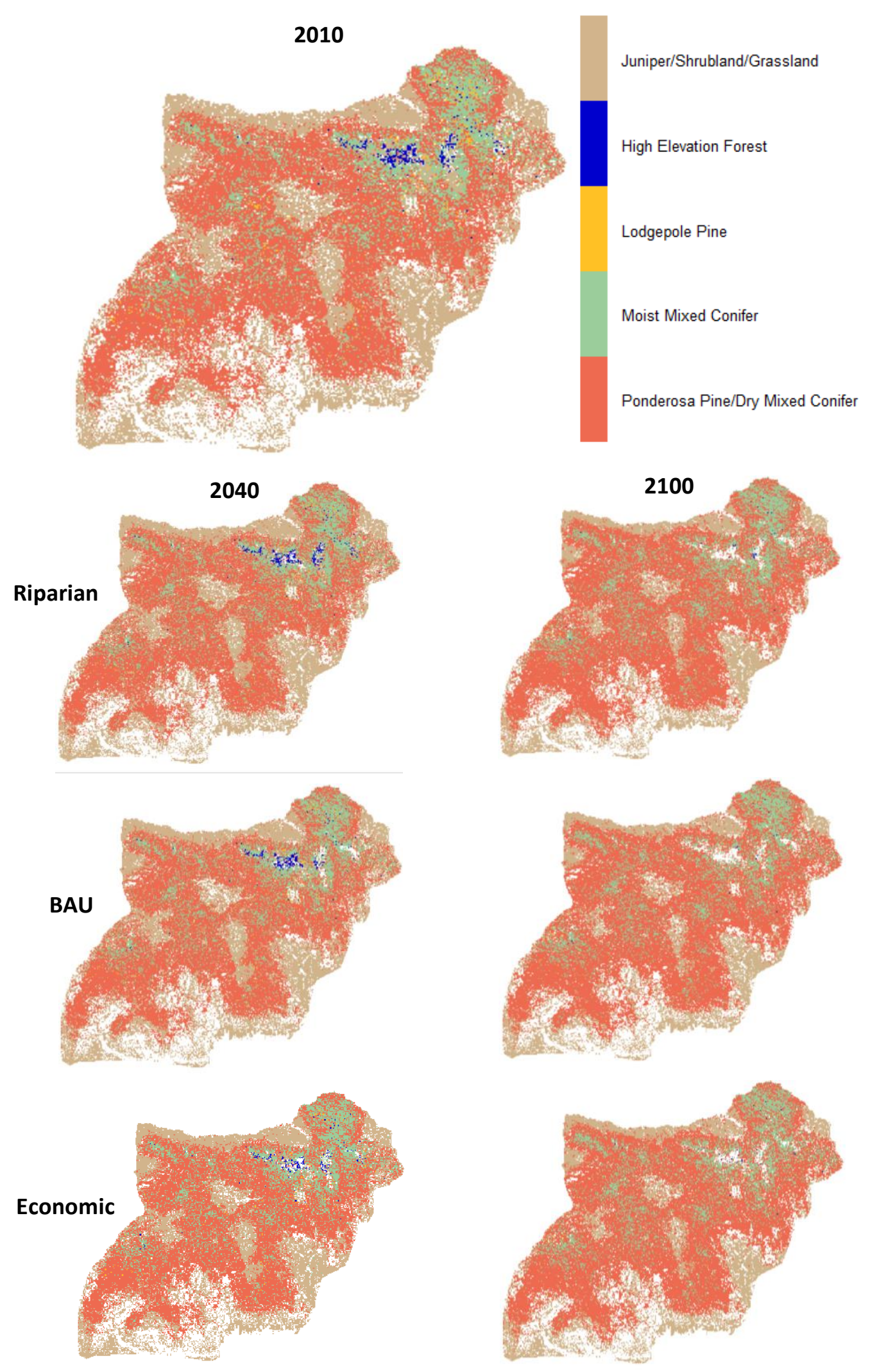
Figure 4.6. Maps of forest type and high-elevation forest loss over time. Initial distribution of forest types is shown in the top map (year 2010). Forest type distribution is shown at year 2040 and year 2100 for each management scenario. Under all scenarios, dry forest expands its range both into low-lying shrublands and into high-elevation sites while high-elevation forest containing Engelmann spruce, whitebark pine, and sub-alpine fir declines. Persistence of these species was highest under the Restoration management scenario, but none of the management strategies prevented losses in this forest type by the end of the century.

\section{High Elevation Forest}

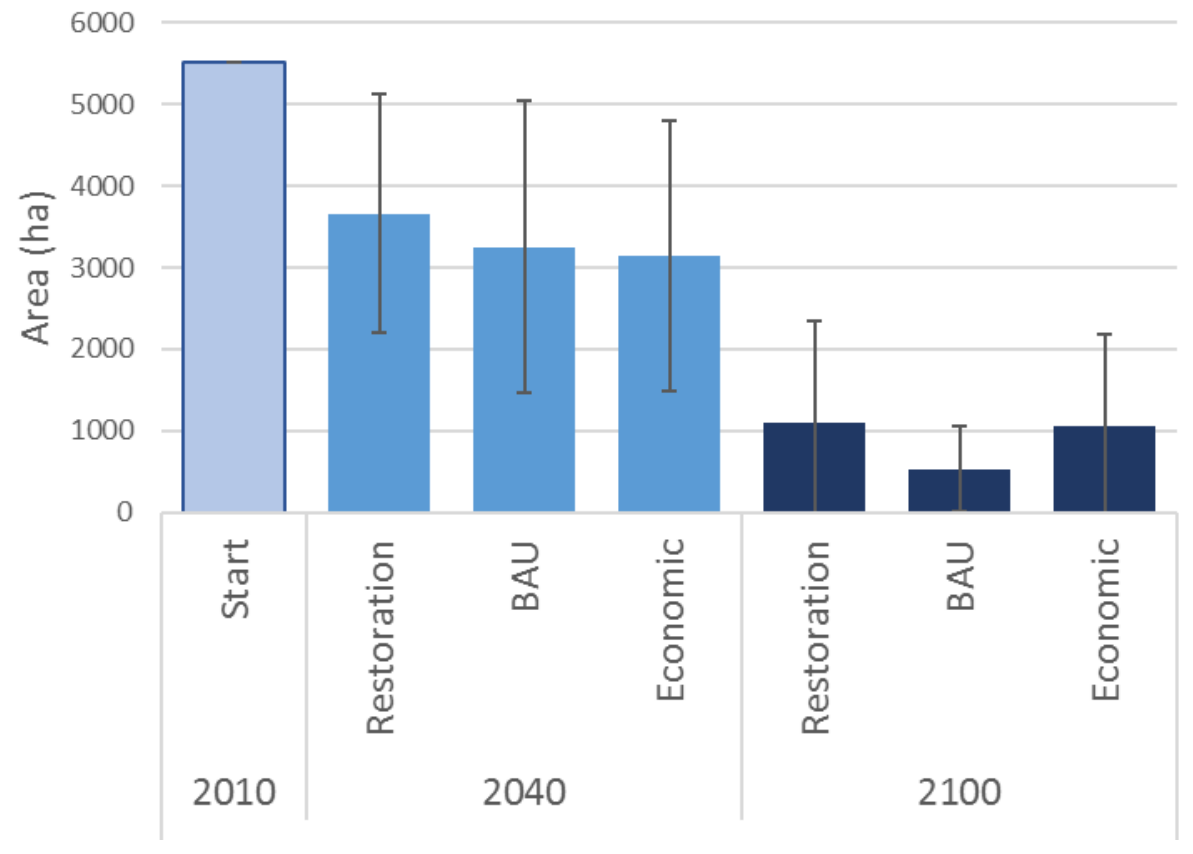

Figure 4.7. High-elevation forest declines under all management scenarios. In the short-term, the Restoration strategy preservers the greatest area of high-elevation forest and the Economic strategy preserves the least. However, by the end of the century, high-elevation forest occurs on less than 1,200 ha regardless of management.

These differences in harvested biomass, wildfire activity, and sensitive forest persistence provide an opportunity to think about tradeoffs. While the Restoration scenario accomplishes somewhat lower wildfire activity, it does not provide economic inputs through timber harvest. The Economic scenario provides commercial harvest of 
timber, providing economic inputs to the community, but it does not remove dense fuels of small-diameter trees and shrubs and therefore does not improve fire outcomes. Current management levels include both fuels reduction and timber harvest, but do not accomplish either objective to the satisfaction of the local community. However, present efforts by the USFS to accelerate the pace of forest restoration are clear evidence of their desire to increase the amount of management for the benefit of both forest health and economic stimulus. One example is the Southern Blues Restoration Coalition Collaborative Landscape Restoration Project, which brings together agency managers and scientists, conservation groups, members of the timber industry, and local residents to identify management projects, develop management plans, and work with the USFS for implementation. Funded through the Collaborative Forest Landscape Restoration Program (Butler et al. 2015), in the first four years of the project they treated nearly 18,000 ha with a combination of commercial harvest, restoration thinning, and prescribed fire (Southern Blues Restoration Coalition 2015). Another example is the Blue Mountains Forest Resiliency Project, which is part of the USFS strategy to support both forest and community health by managing for forest resiliency to fire and climate change on more than half a million acres in the neighboring Ochoco, Umatilla, and Wallowa-Whitman National Forests (USDA Forest Service 2016b). However, current levels of management are not seen as satisfactory by some members of the community in terms of either fuels management or commercial harvest. 
Buchy and Noverman (2000) said that, "power is central to participatory forestry." This sentiment rings true through this study, especially where "power" is another way to think about the ability to make decisions. The history of the timber industry in the region contains dual narratives that are adopted simultaneously by the community. In one narrative, the timber industry of the mid-19 ${ }^{\text {th }}$ century operated successfully and built a strong community with economic sustainability until government-led environmental objectives began to outweigh economic ones and the industry collapsed. In the other, Congressional mandates led the timber industry to overharvest, taking too many of the large trees and paving the way for thickets of young trees and a greater proportion of fire sensitive species. In both of these narratives, the central theme is the power of decision making being wrested from the local community by a centralized, far-off government. There is no doubt that on public lands the decisionmaking authority lies in the hands of whichever government agency has the responsibility of management. However, the opportunities for public participation and comment, both individually and as part of a formal collaborative forestry group, are plentiful. The community is divided in their views of the usefulness of that participation, which points to the need not only for additional outreach by government agencies but also for more showcasing of the outcomes of collaboration.

\subsubsection{Limitations}

There are several approaches to PPGIS studies that result in data in different formats, namely points or polygons, each of which have strengths and weaknesses 
(Brown and Pullar 2012). Mapping data can be collected in person, as done in this study, through the mail (as in Nielsen-Pincus et al. 2010) or electronically (as in Brown and Donovan 2013). When designing this study, I considered all of these options in the context of the study community and by consulting with other researchers and leaders in the community. I decided that in-person focus groups would garner more in-depth information and salient quotes than a mailed or online survey and that because the local population is under 10,000 including the ten nearest town communities (US Census Bureau, 2016) that it would be difficult to recruit a sufficient sample of the population to produce a satisfactory number of points on an electronically-collected PPGIS map. For these reasons I elected to conduct the mapping activity in conjunction with the focus groups.

The data gathered were useful, and the mapping activity served as a catalyst to apply participants' overall philosophies about fuel treatments to the landscape, but many participants expressed discomfort with drawing polygons and in fact some refused to do so. Those who did not draw nevertheless used the maps to point out areas that they felt should or should not be treated, and the maps served to facilitate additional conversation about fuel treatment preferences. In this way, they were a useful tool for developing spatial strategies for alternate management scenarios. However, I feel that directly using polygons on this size of landscape (nearly 1 million hectares) was not successful as a direct way to delineate management areas. Future research should 
consider including an online mapping exercise that may reach a greater number of participants.

Another challenge in qualitative research is ensuring sufficient sampling of the population of interest. For this study, I was interested in capturing the range of fuel treatment preferences within the local community around the Malheur National Forest. Therefore, the results of this study should not be considered to be generalizable to other rural populations. I did not seek out the viewpoints of stakeholders who do not reside in the area, so these results do not reflect, for instance, the viewpoints of individuals from conservation groups that participate in the public input process for projects that occur on the Malheur but who do not reside locally.

\subsection{Conclusion}

Most focus group participants agreed that they want to see more, not less, management on the landscape, and this sentiment crossed philosophical boundaries. For some participants, increased management meant more economic opportunity through commercial harvest. For others the focus was on restoration of old forest structure and fuels reduction to create forests that are more resilient to wildfire. And for most, they prioritized both of these benefit categories. Current management utilizes a range of strategies including fuels reduction and commercial harvest in conjunction with managing for wildlife habitat, old growth structure, meadow and riparian restoration, and other multiple-use objectives but is constrained by limits in both budget and in social acceptability. If communication between the agencies and the 
community increases, facilitated by the collaborative forestry groups, cooperation may help both entities meet their forest and fuels management goals. 


\section{Chapter 5 - Conclusions}

Increasing incidence of large severe wildfires in the western U.S. is a multi-tiered "wicked" problem, and decisions about its management require both a multi-tiered approach and an understanding of future trajectories and implications of these elevated levels of wildfire activity. Wildfire has impacts on both ecological and social systems, and likewise, forest management decisions have long-lasting effects on both forests and people. This study took a three-pronged approach to investigating the effects of wildfire and forest management at the landscape scale in a dry mixed-conifer landscape in eastern Oregon, U.S.: 1. How will climate change and wildfire interact with forest dynamics, and how will those interactions differ under the range of projected climate conditions? 2. How well do fuels management strategies perform under the extreme weather conditions that are becoming more frequent, and can we maintain their effectiveness while spatially optimizing treatment placement? and 3 . What are the range of viewpoints about fuels management in a rural community affected by wildfire, and are there areas of agreement that can provide a win-win strategy for fuels managers who need to satisfy both ecological and social imperatives?

In the first chapter, in order to understand the interactions between weather, forest dynamics, and wildfire under the range of projected climate futures, I simulated forest and fire disturbance under three climate scenarios: contemporary weather and projected weather under moderate (RCP 4.5) and high (RCP 8.5) climate change models. These simulations were run for 90 years, and the last 30 years of wildfire and forest 
composition data were analyzed to capture the differences after historical and projected weather trends diverged. I found that under climate change, wildfire activity was more frequent, more widespread, and more severe than under contemporary conditions, however, there was not a significant difference between moderate and high emissions scenarios. This was a reflection of the overlapping ranges of temperature and precipitation conditions projected under different global circulation models for each of the relative concentration pathways.

Second, I tested the effects of alternate management strategies on wildfire activity to determine the added benefits of treating in riparian areas or adding additional prescribed fire as well as to determine the relative effectiveness of constraining spatial placement of treatments in areas at the most risk for high-severity fire. At the landscape level, fuel treatments in riparian areas and doubling the annual area treated with prescribed fire was insufficient to modify wildfire behavior. Tripling the annual area treated with prescribed fire was required to shift patterns of fire spread and severity. While this is a substantial increase from the area treated today, prescribed fire is a less expensive supplement to mechanical treatments and provides additional ecological benefits in historically fire-maintained forests. While spatial optimization of mechanical treatments in areas at the greatest risk for high-severity fire was equally effective in reducing wildfire activity at the landscape-scale when compared with distributed treatments, it was not effective to constrain prescribed fire in those locations. Distributing prescribed fire across the landscape was substantially more 
effective. The greatest barrier to increasing the rate of prescribed fire is social acceptability, and distributing prescribed fire broadly will increase its visibility and potential for public opposition. This points to a greater need for increased public outreach and education about the benefits of prescribed fire for local forest health and for public safety.

Finally, in order to ascertain the range of community preferences around fuels management, I conducted focus groups and interviews with local residents and used a public participation geographic information systems (PPGIS) activity to delineate the breadth and the overlap of preferred strategies. I used this information to develop alternative fuels management scenarios: light treatment that used only prescribed fire and pre-commercial thinning to reduce fuel loading (Restoration), business as usual management that employed prescribed fire, pre-commercial thinning, and some commercial harvest (BAU), and multi-aged commercial harvest on a 50-year rotation (Economic). I compared the decadal biomass harvested in these treatments as well as their effects on wildfire activity and the distribution of forest types on the landscape. I found that the Economic scenario harvested three times the biomass as BAU and six times the biomass as Restoration, but this exercise does not reflect local capacity to handle large amounts of timber. Therefore this strategy would necessitate additional local mills to be opened and operated or for the timber to leave the community and be processed at mills in other locations. The Restoration strategy would not require any timber processing as no commercially viable trees would be cut, but it would produce a 
large amount of non-commercial woody debris that could be used for non-timber wood products such as biomass for energy.

Although there was a large difference in the amount and age-classes of biomass removed in each scenario, there was no significant difference in wildfire activity over the 90-year simulation period. Annual area burned was lowest and the most stable under the Restoration scenario, likely because this strategy consistently treated just over $1 \%$ of the landscape per year with a specific focus on reducing fuels to increase stand mean diameter and height to live crown. Area burned increased slowly over the simulation period as tree reproduction outpaced the rate of treatment. Although not statistically significant, fire severity was also the lowest under the Restoration scenario. For the first half of the century, the Economic scenario had lower area burned than BAU, but after 55 years, area burned overtook that of BAU, indicating that the focus on extraction of commercially-sized trees over intentionally targeting areas with high fuel loading was not sustainable over the long term.

Also notable, the Economic scenario allowed a small amount of commercial harvest and some pre-commercial thinning in wilderness areas. While it was hypothesized that this strategy could benefit high-elevation forest, which occurs most often in wilderness areas and is susceptible to high-severity fires, that was not the outcome. The results of Chapter 2 found that under climate change this forest type would largely disappear from the landscape within about 30 years, and this was linked with repeated fires in high-elevation sites with steep slopes. The idea that allowing 
some treatment in wilderness areas could prolong this sensitive forest was not supported by the simulation results, as the Economic strategy resulted in the least amount of high-elevation forest persistence after 30 years, while the Restoration scenario performed the best. These results confirm the supposition in Chapter 2 that these forests may be faced with an inevitable loss of these climate- and fire-sensitive species.

This dissertation documented the trajectory of wildfire activity and forest composition changes under the range of projected future climate conditions, assessed the relative effectiveness of fuel treatment strategies, and explored the potential for treatment strategies that reflect the range of preferences held by local residents. It is clear that forest change related to climate change and disturbance is inevitable and that while management is imperative to minimize damages from wildfire to ecological and social systems, large wildfires will be a continuing disturbance on this landscape. Future increases in ponderosa pine dominance may act as a mediating force on future wildfire spread, but losses in tree species richness and heterogeneity on the landscape have implications for other disturbances and social values. Forest managers will need to carefully consider priorities around the economics of fuel treatments as well as the longterm impacts of decisions that are made today. 


\section{References}

\section{Chapter 1 References}

Abatzoglou, J. T., \& Williams, A. P. (2016). Impact of anthropogenic climate change on wildfire across western US forests. Proceedings of the National Academy of Sciences, 113(42), 11770-11775. https://doi.org/10.1073/pnas.1607171113

Ager, A. A., Vaillant, N. M., \& Finney, M. A. (2010). A comparison of landscape fuel treatment strategies to mitigate wildland fire risk in the urban interface and preserve old forest structure. Forest Ecology and Management, 259(8), 15561570. https://doi.org/10.1016/j.foreco.2010.01.032

Armitage, D. R., Plummer, R., Berkes, F., Arthur, R. I., Charles, A. T., Davidson-Hunt, I. J., ... Wollenberg, E. K. (2009). Adaptive co-management for social-ecological complexity. Frontiers in Ecology and the Environment, 7(2), 95-102. https://doi.org/10.1890/070089

Bengston, D. N. (1994). Changing forest values and ecosystem management. Society \& Natural Resources, 7(6), 515-533.

Brenkert-Smith, H., Champ, P. A., \& Flores, N. (2006). Insights into wildfire mitigation decisions among wildland-urban interface residents. Society \& Natural Resources, 19(8), 759-768. https://doi.org/10.1080/08941920600801207

Brunson, M. W. (1993). "Socially acceptable" forestry: What does it imply for ecosystem management. Western Journal of Applied Forestry, 8(4), 116-119.

Churchill, D. J., Larson, A. J., Dahlgreen, M. C., Franklin, J. F., Hessburg, P. F., \& Lutz, J. A. (2013). Restoring forest resilience: From reference spatial patterns to silvicultural prescriptions and monitoring. Forest Ecology and Management, 291, 442-457. https://doi.org/10.1016/j.foreco.2012.11.007

Dent, J. (2008). Civic capacity and community response to government action: The Endangered Species Act and state water law in the Methow and Walla Walla basins in the Pacific Northwest. International Journal of Public Administration, 31(3), 262-276. https://doi.org/10.1080/01900690701590439

Franklin, J. F., \& Johnson, K. N. (2012). A restoration framework for federal forests in the Pacific Northwest. Journal of Forestry, 110(8), 429-439. https://doi.org/10.5849/jof.10-006

Fried, J. S., Gilless, J. K., Riley, W. J., Moody, T. J., De Blas, C. S., Hayhoe, K., ... Torn, M. (2008). Predicting the effect of climate change on wildfire behavior and initial attack success. Climatic Change, 87(Suppl 1), S251-S264. https://doi.org/10.1007/s10584-007-9360-2 
Fulé, P. Z., Waltz, A. E., Covington, W. W., \& Heinlein, T. A. (2001). Measuring forest restoration effectiveness in reducing hazardous fuels. Journal of Forestry, 99(11), 24-29.

Gordon, J. S., Matarrita-Cascante, D., Stedman, R. C., \& Luloff, A. E. (2010). Wildfire perception and community change. Rural Sociology, 75(3), 455-477. https://doi.org/10.1111/j.1549-0831.2010.00021.x

Hagmann, R. K., Franklin, J. F., \& Johnson, K. N. (2014). Historical conditions in mixedconifer forests on the eastern slopes of the northern Oregon Cascade Range, USA. Forest Ecology and Management, 330, 158-170.

https://doi.org/10.1016/j.foreco.2014.06.044

Halofsky, J. S., Halofsky, J. E., Burcsu, T., \& Hemstrom, M. A. (2014). Dry forest resilience varies under simulated climate-management scenarios in a central Oregon, USA landscape. Ecological Applications, 24(8), 1908-1925.

Heyerdahl, E. K., Brubaker, L. B., \& Agee, J. K. (2002). Annual and decadal climate forcing of historical fire regimes in the interior Pacific Northwest, USA. The Holocene, 12(5), 597-604. https://doi.org/10.1191/0959683602hl570rp

Johnson, M. C., Kennedy, M. C., \& Peterson, D. L. (2011). Simulating fuel treatment effects in dry forests of the western United States: Testing the principles of a fire-safe forest. Canadian Journal of Forest Research, 41, 1018-1030. https://doi.org/10.1139/X11-032

Johnston, J. D., Bailey, J. D., Dunn, C. J., \& Lindsay, A. A. (2017). Historical fire-climate relationships in contrasting interior Pacific Northwest forest types. Fire Ecology, 13(2), 18-36. https://doi.org/10.4996/fireecology.130257453

Keane, R. E., Hessburg, P. F., Landres, P. B., \& Swanson, F. J. (2009). The use of historical range and variability (HRV) in landscape management. Forest Ecology and Management, 258(7), 1025-1037. https://doi.org/10.1016/j.foreco.2009.05.035

Littell, J. S., McKenzie, D., Peterson, D. L., \& Westerling, A. L. (2009). Climate and wildfire area burned in western U.S. ecoprovinces, 1916-2003. Ecological Applications, 19(4), 1003-1021.

Loudermilk, E. L., Stanton, A., Scheller, R. M., Dilts, T. E., Weisberg, P. J., Skinner, C., \& Yang, J. (2014). Effectiveness of fuel treatments for mitigating wildfire risk and sequestering forest carbon: A case study in the Lake Tahoe Basin. Forest Ecology and Management, 323, 114-125.

McCaffrey, S., Toman, E., Stidham, M., \& Shindler, B. (2013). Social science research related to wildfire management: An overview of recent findings and future 
research needs. International Journal of Wildland Fire, 22(1), 15. https://doi.org/10.1071/WF11115

Potapchuk, W. R., \& Crocker Jr, J. P. (1999). Exploring the elements of civic capital. National Civic Review, 88(3), 175-202.

Prichard, S. J., Peterson, D. L., \& Jacobson, K. (2010). Fuel treatments reduce the severity of wildfire effects in dry mixed conifer forest, Washington, USA. Canadian Journal of Forest Research, 4O(8), 1615-1626. https://doi.org/10.1139/X10-109

Radeloff, V. C., Hammer, R. B., Stewart, S. I., Fried, J. S., Holcomb, S. S., \& McKeefry, J. F. (2005). The wildland-urban interface in the United States. Ecological Applications, 15(3), 799-805.

Safford, H. D., Stevens, J. T., Merriam, K., Meyer, M. D., \& Latimer, A. M. (2012). Fuel treatment effectiveness in California yellow pine and mixed conifer forests. Forest Ecology and Management, 274, 17-28. https://doi.org/10.1016/j.foreco.2012.02.013

Schwilk, D. W., Keeley, J. E., Knapp, E. E., Mclver, J., Bailey, J. D., Fettig, C. J., ... Outcalt, K. W. (2009). The National Fire and Fire Surrogate study: Effects of fuel reduction methods on forest vegetation structure and fuels. Ecological Applications, 19(2), 285-304.

Shindler, B. A., Brunson, M., \& Stankey, G. H. (2002). Social acceptability of forest conditions and management practices: a problem analysis. (General Technical Report No. PNW-GTR-537). Portland, OR: USDA Forest Service, Pacific Northwest Research Station. Retrieved from http://www.treesearch.fs.fed.us/pubs/3242

Syphard, A. D., Keeley, J. E., \& Brennan, T. J. (2011). Comparing the role of fuel breaks across southern California national forests. Forest Ecology and Management, 261(11), 2038-2048. https://doi.org/10.1016/j.foreco.2011.02.030

Theobald, D. M. (2001). Land-use dynamics beyond the American urban fringe. Geographical Review, 91(3), 544-564.

Torn, M. S., \& Fried, J. S. (1992). Predicting the impacts of global warming on wildland fire. Climatic Change, 21, 257-274. https://doi.org/10.1007/BF00139726

U.S. EPA. (2017, February 6). How citizens can comment and participate in the National Environmental Policy Act process. Retrieved from https://www.epa.gov/nepa/how-citizens-can-comment-and-participatenational-environmental-policy-act-process

Westerling, A. L., Hidalgo, H. G., Cayan, D. R., \& Swetnam, T. W. (2006). Warming and earlier spring increase western U.S. forest wildfire activity. Science, 313, 940943. https://doi.org/10.1126/science.1130691 


\section{Chapter 2 References}

Abatzoglou, J. T. (2013). Development of gridded surface meteorological data for ecological applications and modelling. International Journal of Climatology, 33(1), 121-131. https://doi.org/10.1002/joc.3413

Abatzoglou, J. T., \& Williams, A. P. (2016). Impact of anthropogenic climate change on wildfire across western US forests. Proceedings of the National Academy of Sciences, 113(42), 11770-11775. https://doi.org/10.1073/pnas.1607171113

Agee, J. K. (1998). The landscape ecology of western forest fire regimes. Northwest Science, 72(Special Issue), 24-34.

Agee, J. K., \& Skinner, C. N. (2005). Basic principles of forest fuel reduction treatments. Forest Ecology and Management, 211, 83-96. https://doi.org/10.1016/j.foreco.2005.01.034

Anderson, M. D. (2003). Pinus contorta var. latifolia. Retrieved February 23, 2018, from https://www.fs.fed.us/database/feis/plants/tree/pinconl/all.html\#AUTHORSHIP \%20AND\%20CITATION

Anderson, M. J. (2001). A new method for non-parametric multivariate analysis of variance. Austral Ecology, 26(1), 32-46.

Beals, E. W. (1984). Bray-Curtis ordination: An effective strategy for analysis of multivariate ecological data. Advances in Ecological Research, 14, 1-55.

Brown, P. M., Heyerdahl, E. K., Kitchen, S. G., \& Weber, M. H. (2008). Climate effects on historical fires (1630-1900) in Utah. International Journal of Wildland Fire, 17(1), 28. https://doi.org/10.1071/WF07023

Carpenter, S., Walker, B., Anderies, J. M., \& Abel, N. (2001). From metaphor to measurement: Resilience of what to what? Ecosystems, 4(8), 765-781. https://doi.org/10.1007/s10021-001-0045-9

Cayan, D. R., Redmond, K. T., \& Riddle, L. G. (1999). ENSO and hydrologic extremes in the western United States. Journal of Climate, 12(9), 2881-2893.

Churchill, D. J., Larson, A. J., Dahlgreen, M. C., Franklin, J. F., Hessburg, P. F., \& Lutz, J. A. (2013). Restoring forest resilience: From reference spatial patterns to silvicultural prescriptions and monitoring. Forest Ecology and Management, 291, 442-457. https://doi.org/10.1016/j.foreco.2012.11.007

Clarke, K. R. (1993). Non-parametric multivariate analyses of changes in community structure. Australian Journal of Ecology, 18, 117-143.

Coops, N. C., Waring, R. H., \& Law, B. E. (2005). Assessing the past and future distribution and productivity of ponderosa pine in the Pacific Northwest using a 
process model, 3-PG. Ecological Modelling, 183(1), 107-124.

https://doi.org/10.1016/j.ecolmodel.2004.08.002

Creutzburg, M. K., Scheller, R. M., Lucash, M. S., Evers, L. B., LeDuc, S. D., \& Johnson, M. G. (2016). Bioenergy harvest, climate change, and forest carbon in the Oregon Coast Range. GCB Bioenergy, 8(2), 357-370. https://doi.org/10.1111/gcbb.12255

Crowe, E. A., \& Clausnitzer, R. R. (1997). Mid-montane wetland plant associations of the Malheur, Umatilla, and Wallowa-Whitman National Forests. US Department of Agriculture, Forest Service, Pacific Northwest Region, Wallowa-Whitman National Forest.

Duveneck, M. J., Scheller, R. M., \& White, M. A. (2014). Effects of alternative forest management on biomass and species diversity in the face of climate change in the northern Great Lakes region (USA). Canadian Journal of Forest Research, 44(7), 700-710. https://doi.org/10.1139/cjfr-2013-0391

Dwire, K. A., Mellmann-Brown, S., \& Gurrieri, J. T. (2017). Potential effects of climate change on riparian areas, wetlands, and groundwater-dependent ecosystems in the Blue Mountains, Oregon, USA. Climate Services. https://doi.org/10.1016/j.cliser.2017.10.002

Folke, C., Carpenter, S., Walker, B., Scheffer, M., Elmqvist, T., Gunderson, L., \& Holling, C. S. (2004). Regime shifts, resilience, and biodiversity in ecosystem management. Annual Review of Ecology, Evolution, and Systematics, 35(1), 557-581. https://doi.org/10.1146/annurev.ecolsys.35.021103.105711

Franklin, J. F., \& Dyrness, C. T. (1973). Natural vegetation of Oregon and Washington (Gen. Tech. Rep. No. GTR-PNW-8). Portland, OR: USDA Forest Service, Pacific Northwest Forest and Range Experiment Station. Retrieved from http://www.treesearch.fs.fed.us/pubs/7704

Franklin, J. F., \& Johnson, K. N. (2012). A restoration framework for federal forests in the Pacific Northwest. Journal of Forestry, 110(8), 429-439. https://doi.org/10.5849/jof.10-006

Fulé, P. Z., Swetnam, T. W., Brown, P. M., Falk, D. A., Peterson, D. L., Allen, C. D., ... others. (2014). Unsupported inferences of high-severity fire in historical dry forests of the western United States: Response to Williams and Baker. Global Ecology and Biogeography, 23(7), 825-830.

Gustafson, E. J. (2013). When relationships estimated in the past cannot be used to predict the future: Using mechanistic models to predict landscape ecological dynamics in a changing world. Landscape Ecology, 28(8), 1429-1437. https://doi.org/10.1007/s10980-013-9927-4 
Habeck, J. R., \& Mutch, R. W. (1973). Fire-dependent forests in the northern Rocky Mountains. Quaternary Research, 3, 408-424.

Hagmann, R. K., Franklin, J. F., \& Johnson, K. N. (2014). Historical conditions in mixedconifer forests on the eastern slopes of the northern Oregon Cascade Range, USA. Forest Ecology and Management, 330, 158-170.

https://doi.org/10.1016/j.foreco.2014.06.044

Halofsky, J. E., Hemstrom, M. A., Conklin, D. R., Halofsky, J. S., Kerns, B. K., \& Bachelet, D. (2013). Assessing potential climate change effects on vegetation using a linked model approach. Ecological Modelling, 266, 131-143. https://doi.org/10.1016/j.ecolmodel.2013.07.003

Hamlet, A. F., Mote, P. W., Clark, M. P., \& Lettenmaier, D. P. (2007). Twentieth-century trends in runoff, evapotranspiration, and soil moisture in the Western United States. Journal of Climate, 20(8), 1468-1486. https://doi.org/10.1175/JCLI4051.1

Hessburg, P. F., Agee, J. K., \& Franklin, J. F. (2005). Dry forests and wildland fires of the inland Northwest USA: Contrasting the landscape ecology of the pre-settlement and modern eras. Forest Ecology and Management, 211(1-2), 117-139. https://doi.org/10.1016/j.foreco.2005.02.016

Heyerdahl, E. K. (1997). Spatial and temporal variation in historical fire regimes of the Blue Mountains, Oregon and Washington: The influence of climate (Doctoral dissertation). University of Washington, Seattle, WA. Retrieved from https://dlib.lib.washington.edu/researchworks/bitstream/handle/1773/5575/98 19247.pdf?sequence $=1$

Heyerdahl, E. K., \& Agee, J. K. (1996). Historical fire regimes of four sites in the Blue Mountains, Oregon and Washington (Final Report) (p. 173). Seattle, WA: College of Forest Resources, University of Washington. Retrieved from http://www.fs.fed.us/rm/pubs/rmrs_gtr292/2001_powell.pdf

Heyerdahl, E. K., \& Alvarado, E. (2003). Influence of climate and land use on historical surface fires in pine-oak forests, Sierra Madre Occidental, Mexico. In T. T. Veblen, W. L. Baker, G. Montenegro, \& T. W. Swetnam (Eds.), Fire and climatic change in temperate ecosystems of the western Americas (Vol. 160, pp. 196217). New York, NY: Springer.

Heyerdahl, E. K., Brubaker, L. B., \& Agee, J. K. (2001). Spatial controls of historical fire regimes: A multiscale example from the interior west, USA. Ecology, 82(3), 660. https://doi.org/10.2307/2680187 
Heyerdahl, E. K., Brubaker, L. B., \& Agee, J. K. (2002). Annual and decadal climate forcing of historical fire regimes in the interior Pacific Northwest, USA. The Holocene, 12(5), 597-604. https://doi.org/10.1191/0959683602hl570rp

Howard, J. L., \& Aleksoff, K. C. (2000). Abies grandis. In: Fire Effects Information System, [Online]. U.S. Department of Agriculture, Forest Service, Rocky Mountain Research Station, Fire Sciences Laboratory (Producer). Retrieved from https://www.fs.fed.us/database/feis/plants/tree/abigra/all.html

Johnson, M. C., Kennedy, M. C., \& Peterson, D. L. (2011). Simulating fuel treatment effects in dry forests of the western United States: Testing the principles of a fire-safe forest. Canadian Journal of Forest Research, 41, 1018-1030. https://doi.org/10.1139/X11-032

Johnston, J. D., Bailey, J. D., \& Dunn, C. J. (2016). Influence of fire disturbance and biophysical heterogeneity on pre-settlement ponderosa pine and mixed conifer forests. Ecosphere, 7(11), e01581. https://doi.org/10.1002/ecs2.1581

Keane, R. E., Hessburg, P. F., Landres, P. B., \& Swanson, F. J. (2009). The use of historical range and variability (HRV) in landscape management. Forest Ecology and Management, 258(7), 1025-1037. https://doi.org/10.1016/j.foreco.2009.05.035

Kretchun, A. M., Loudermilk, E. L., Scheller, R. M., Hurteau, M. D., \& Belmecheri, S. (2016). Climate and bark beetle effects on forest productivity-linking dendroecology with forest landscape modeling. Canadian Journal of Forest Research, 46(8), 1026-1034.

Kretchun, A. M., Scheller, R. M., Lucash, M. S., Clark, K. L., Hom, J., \& Van Tuyl, S. (2014). Predicted effects of gypsy moth defoliation and climate change on forest carbon dynamics in the New Jersey Pine Barrens. PLOS ONE, 9(8), e102531.

https://doi.org/10.1371/journal.pone.0102531

Langston, N. (1995). Forest dreams, forest nightmares: The paradox of old growth in the Inland West. Seattle, WA: University of Washington Press.

Larson, A. J., \& Churchill, D. (2012). Tree spatial patterns in fire-frequent forests of western North America, including mechanisms of pattern formation and implications for designing fuel reduction and restoration treatments. Forest Ecology and Management, 267, 74-92.

https://doi.org/10.1016/j.foreco.2011.11.038

Lillybridge, T. R., Kovalchik, B. L., Williams, C. K., \& Smith, B. G. (1995). Field guild for forested plant associations of the Wenatchee National Forest (General Technical Report No. PNW-GTR-359) (p. 336). Portland, OR: USDA Forest Service, Pacific Northwest Research Station. 
Littell, J. S., McKenzie, D., Peterson, D. L., \& Westerling, A. L. (2009). Climate and wildfire area burned in western U.S. ecoprovinces, 1916-2003. Ecological Applications, 19(4), 1003-1021.

Littell, J. S., Peterson, D. L., Riley, K. L., Liu, Y., \& Luce, C. H. (2016). Fire and drought. In J. Vose, J. S. Clark, C. Luce, \& T. Patel-Weynand (Eds.), Effects of drought on forests and rangelands in the United States: A comprehensive science synthesis (pp. 135-154). Washington, DC: USDA Forest Service, Washington Office. Retrieved from http://www.treesearch.fs.fed.us/pubs/50261

Loudermilk, E. L., Scheller, R. M., Weisberg, P. J., \& Kretchun, A. (2017). Bending the carbon curve: Fire management for carbon resilience under climate change. Landscape Ecology, 32(7), 1461-1472. https://doi.org/10.1007/s10980-0160447-x

Loudermilk, E. L., Stanton, A., Scheller, R. M., Dilts, T. E., Weisberg, P. J., Skinner, C., \& Yang, J. (2014). Effectiveness of fuel treatments for mitigating wildfire risk and sequestering forest carbon: A case study in the Lake Tahoe Basin. Forest Ecology and Management, 323, 114-125.

Lucash, M. S., Scheller, R. M., J. Gustafson, E., \& R. Sturtevant, B. (2017). Spatial resilience of forested landscapes under climate change and management. Landscape Ecology, 32(5), 953-969. https://doi.org/10.1007/s10980-017-0501-3

Lucash, M. S., Scheller, R. M., Kretchun, A. M., Clark, K. L., \& Hom, J. (2014). Impacts of fire and climate change on long-term nitrogen availability and forest productivity in the New Jersey Pine Barrens. Canadian Journal of Forest Research, 44(5), 404412. https://doi.org/10.1139/cjfr-2013-0383

Mathys, A. S., Coops, N. C., \& Waring, R. H. (2017). An ecoregion assessment of projected tree species vulnerabilities in western North America through the 21st century. Global Change Biology, 23(2), 920-932. https://doi.org/10.1111/gcb.13440

Maurer, E. P., Wood, A. W., Adam, J. C., Lettenmaier, D. P., \& Nijssen, B. (2002). A longterm hydrologically based dataset of land surface fluxes and states for the conterminous United States. Journal of Climate, 15(22), 3237-3251.

McCune, B., \& Grace, J. B. (2002). Analysis of ecological communities. Gleneden Beach, OR: MjM Software Design.

Monitoring Trends in Burn Severity. (2017, July). Retrieved September 17, 2017, from https://www.mtbs.gov/

Mote, P. W., \& Salathé, E. P. (2010). Future climate in the Pacific Northwest. Climatic Change, 102(1-2), 29-50. https://doi.org/10.1007/s10584-010-9848-z 
NOAA. (2016). 1981-2010 US Normals Data. Retrieved April 11, 2016, from http://gis.ncdc.noaa.gov/map/viewer/\#app=cdo\&cfg=cdo\&theme=normals\&laye rs=01\&node=gis\&extent=-149.3:20.2:-60.1:69.6\&custom=normals

NOAA, C. P. C. (2005). Climate Prediction Center - North American Winter Features. Retrieved October 5, 2015, from http://www.cpc.ncep.noaa.gov/products/analysis_monitoring/ensocycle/nawint er.shtml

Odion, D. C., Hanson, C. T., Arsenault, A., Baker, W. L., DellaSala, D. A., Hutto, R. L., ... Williams, M. A. (2014). Examining historical and current mixed-severity fire regimes in ponderosa pine and mixed-conifer forests of western North America. PLoS ONE, 9(2), e87852. https://doi.org/10.1371/journal.pone.0087852

Oksanen, J., Blanchet, F. G., Friendly, M., Kindt, R., Legendre, P., McGlinn, D., ... Wagner, H. (2017). vegan: Community Ecology Package. R package version 2.4-5. Retrieved from https://CRAN.R-project.org/package=vegan

Oliver, T. H., Heard, M. S., Isaac, N. J. B., Roy, D. B., Procter, D., Eigenbrod, F., ... Bullock, J. M. (2015). Biodiversity and resilience of ecosystem functions. Trends in Ecology \& Evolution, 30(11), 673-684. https://doi.org/10.1016/j.tree.2015.08.009

Pachauri, R. K., Allen, M. R., Barros, V. R., Broome, J., Cramer, W., Christ, R., ... others. (2014). Climate change 2014: Synthesis report. Contribution of Working Groups I, II and III to the Fifth Assessment Report of the Intergovernmental Panel on Climate Change. IPCC. Retrieved from http://epic.awi.de/37530/

Parsons, D. J., \& DeBenedetti, S. H. (1979). Impact of fire suppression on a mixed-conifer forest. Forest Ecology and Management, 2, 21-33.

Parton, W., Ojima, D., \& Kirchner, T. (1993). Observations and modeling of biomass and soil organic matter dynamics for the grassland biome worldwide. Global Biogeochemical Cycles, 7(4), 785-809.

Perkins, D. L., Means, R. E., \& Cochrane, A. C. (2016). Conservation and management of whitebark pine ecosystems on Bureau of Land Management Lands in the Western United States (No. Technical Reference 6711-1) (p. 95). Denver, Colorado: Bureau of Land Management.

Sala, A., Carey, E. V., Keane, R. E., \& Callaway, R. M. (2001). Water use by whitebark pine and subalpine fir: Potential consequences of fire exclusion in the northern Rocky Mountains. Tree Physiology, 21(11), 717-725.

Scheller, R. M., Domingo, J. B., Sturtevant, B. R., Williams, J. S., Rudy, A., Gustafson, E. J., \& Mladenoff, D. J. (2007). Design, development, and application of LANDIS-II, a spatial landscape simulation model with flexible temporal and spatial resolution. 
Ecological Modelling, 201(3-4), 409-419.

https://doi.org/10.1016/j.ecolmodel.2006.10.009

Scheller, R. M., Van Tuyl, S., Clark, K., Hayden, N. G., Hom, J., \& Mladenoff, D. J. (2008).

Simulation of forest change in the New Jersey Pine Barrens under current and pre-colonial conditions. Forest Ecology and Management, 255(5-6), 1489-1500. https://doi.org/10.1016/j.foreco.2007.11.025

Schoennagel, T., Veblen, T. T., \& Romme, W. H. (2004). The interaction of fire, fuels, and climate across Rocky Mountain forests. BioScience, 54(7), 661-676.

Scholze, M., Knorr, W., Arnell, N. W., \& Prentice, I. C. (2006). A climate-change risk analysis for world ecosystems. Proceedings of the National Academy of Sciences, 103(35), 13116-13120.

Stephens, S. L., Moghaddas, J. J., Edminster, C., Fiedler, C. E., Haase, S., Harrington, M., ... Youngblood, A. (2009). Fire treatment effects on vegetation structure, fuels, and potential fire severity in western U.S. forests. Ecological Applications, 19(2), 305-320.

Sturtevant, B. R., Miranda, B. R., Scheller, R. M., Shinneman, D., \& Kretchun, A. M. (unpublished). LANDIS-II Dynamic Fire System v3 User Guide.

Sturtevant, B. R., Scheller, R. M., Miranda, B. R., Shinneman, D., \& Syphard, A. (2009). Simulating dynamic and mixed-severity fire regimes: A process-based fire extension for LANDIS-II. Ecological Modelling, 220(23), 3380-3393. https://doi.org/10.1016/j.ecolmodel.2009.07.030

Swetnam, T. W. (1993). Fire history and climate change in giant sequoia groves. Science, 262(5135), 885-889.

Swetnam, T. W., \& Betancourt, J. L. (1990). Fire-southern oscillation relations in the southwestern United States. Science, (249), 1017-1020.

U.S. Department of Agriculture, Forest Service. (2014). Proposed revised land management plans for the Malheur, Wallowa-Whitman and Umatilla National Forests (pp. 1-159). Baker City, OR: U.S. Department of Agriculture, Forest Service.

USDA Forest Service, Malheur National Forest. (2015). CFLR and Partnerships. Retrieved October 7, 2015, from http://www.fs.usda.gov/detailfull/malheur/workingtogether/partnerships/?cid= STELPRDB5244635\& width=full

USGCRP, Mote, P., Snover, A. K., Capalbo, S., S.D. Eigenbrode, Glick, P., ... Reeder, S. (2014). Chapter 21: Northwest. In J. M. Melillo, T. C. Richmond, \& G. W. Yohe 
(Eds.), Climate change impacts in the United States: The Third National Climate Assessment (pp. 487-513). U.S. Global Change Research Program.

Westerling, A. L., Hidalgo, H. G., Cayan, D. R., \& Swetnam, T. W. (2006). Warming and earlier spring increase western U.S. forest wildfire activity. Science, 313, 940943. https://doi.org/10.1126/science.1130691

Whitlock, C. (2003). The role of climate and vegetation change in shaping past and future fire regimes in the northwestern US and the implications for ecosystem management. Forest Ecology and Management., 178(1), 5.

Williams, J. W., \& Jackson, S. T. (2007). Novel climates, no-analog communities, and ecological surprises. Frontiers in Ecology and the Environment, 5(9), 475-482. https://doi.org/10.1890/070037

Williams, M. A., \& Baker, W. L. (2012). Spatially extensive reconstructions show variableseverity fire and heterogeneous structure in historical western United States dry forests. Global Ecology and Biogeography, 21(10), 1042-1052. https://doi.org/10.1111/j.1466-8238.2011.00750.x

Williams, M. A., \& Baker, W. L. (2014). High-severity fire corroborated in historical dry forests of the western United States: Response to Fulé et al. Global Ecology and Biogeography, 23(7), 831-835. 


\section{Chapter 3 References}

Abatzoglou, J. T. (2013). Development of gridded surface meteorological data for ecological applications and modelling. International Journal of Climatology, 33(1), 121-131. https://doi.org/10.1002/joc.3413

Agee, J. K. (1993). Fire ecology of Pacific Northwest forests. Washington: Island Press.

Ager, A. A., Vaillant, N. M., \& Finney, M. A. (2010). A comparison of landscape fuel treatment strategies to mitigate wildland fire risk in the urban interface and preserve old forest structure. Forest Ecology and Management, 259(8), 15561570. https://doi.org/10.1016/j.foreco.2010.01.032

Arkle, R. S., \& Pilliod, D. S. (2010). Prescribed fires as ecological surrogates for wildfires: A stream and riparian perspective. Forest Ecology and Management, 259(5), 893-903. https://doi.org/10.1016/j.foreco.2009.11.029

Barnett, K., Parks, S. A., Miller, C., \& Naughton, H. T. (2016). Beyond fuel treatment effectiveness: Characterizing interactions between fire and treatments in the US. Forests, 7(10), 237.

Bartos, D. L., Brown, J. K., \& Booth, G. D. (1994). Twelve years biomass response in aspen communities following fire. Journal of Range Management, 79-83.

Bêche, L. A., Stephens, S. L., \& Resh, V. H. (2005). Effects of prescribed fire on a Sierra Nevada (California, USA) stream and its riparian zone. Forest Ecology and Management, 218(1-3), 37-59. https://doi.org/10.1016/j.foreco.2005.06.010

Bessie, W., \& Johnson, E. (1995). Relative importance of fuels and weather on fire behavior in subalpine forests. Ecology, 76, 747-762.

Cayan, D. R., Redmond, K. T., \& Riddle, L. G. (1999). ENSO and hydrologic extremes in the western United States. Journal of Climate, 12(9), 2881-2893.

Covington, W. W., \& Sackett, S. S. (1992). Soil mineral nitrogen changes following prescribed burning in ponderosa pine. Forest Ecology and Management, 54(1-4), 175-191.

Creutzburg, M. K., Scheller, R. M., Lucash, M. S., Evers, L. B., LeDuc, S. D., \& Johnson, M. G. (2016). Bioenergy harvest, climate change, and forest carbon in the Oregon Coast Range. GCB Bioenergy, 8(2), 357-370. https://doi.org/10.1111/gcbb.12255

Duncan, B. W., Schmalzer, P. A., Breininger, D. R., \& Stolen, E. D. (2015). Comparing fuels reduction and patch mosaic fire regimes for reducing fire spread potential: $A$ spatial modeling approach. Ecological Modelling, 314, 90-99. https://doi.org/10.1016/j.ecolmodel.2015.07.013

Duveneck, M. J., Scheller, R. M., \& White, M. A. (2014). Effects of alternative forest management on biomass and species diversity in the face of climate change in 
the northern Great Lakes region (USA). Canadian Journal of Forest Research, 44(7), 700-710. https://doi.org/10.1139/cjfr-2013-0391

Dwire, K. A., Mellmann-Brown, S., \& Gurrieri, J. T. (2017). Potential effects of climate change on riparian areas, wetlands, and groundwater-dependent ecosystems in the Blue Mountains, Oregon, USA. Climate Services. https://doi.org/10.1016/j.cliser.2017.10.002

Fernandes, P. A. M., Loureiro, C. A., \& Botelho, H. S. (2004). Fire behaviour and severity in a maritime pine stand under differing fuel conditions. Annals of Forest Science, 61(6), 537-544. https://doi.org/10.1051/forest:2004048

Finney, M. A. (2007). A computational method for optimising fuel treatment locations. International Journal of Wildland Fire, 16(6), 702. https://doi.org/10.1071/WF06063

Finney, M. A., McHugh, C. W., \& Grenfell, I. C. (2005). Stand- and landscape-level effects of prescribed burning on two Arizona wildfires. Canadian Journal of Forest Research, 35(7), 1714-1722. https://doi.org/10.1139/x05-090

Finney, M. A., Seli, R. C., McHugh, C. W., Ager, A. A., Bahro, B., \& Agee, J. K. (2007). Simulation of long-term landscape-level fuel treatment effects on large wildfires. International Journal of Wildland Fire, 16(6), 712. https://doi.org/10.1071/WF06064

Franklin, J. F., \& Dyrness, C. T. (1973). Natural vegetation of Oregon and Washington (Gen. Tech. Rep. No. GTR-PNW-8). Portland, OR: USDA Forest Service, Pacific Northwest Forest and Range Experiment Station. Retrieved from http://www.treesearch.fs.fed.us/pubs/7704

Fried, J. S., Gilless, J. K., Riley, W. J., Moody, T. J., De Blas, C. S., Hayhoe, K., ... Torn, M. (2008). Predicting the effect of climate change on wildfire behavior and initial attack success. Climatic Change, 87(Suppl 1), S251-S264. https://doi.org/10.1007/s10584-007-9360-2

Fulé, P. Z., Waltz, A. E., Covington, W. W., \& Heinlein, T. A. (2001). Measuring forest restoration effectiveness in reducing hazardous fuels. Journal of Forestry, 99(11), 24-29.

Gedalof, Z., Peterson, D. L., \& Mantua, N. J. (2005). Atmospheric, climatic, and ecological controls on extreme wildfire years in the northwestern United States. Ecological Applications, 15(1), 154-174.

Gustafson, E. J. (2013). When relationships estimated in the past cannot be used to predict the future: Using mechanistic models to predict landscape ecological 
dynamics in a changing world. Landscape Ecology, 28(8), 1429-1437.

https://doi.org/10.1007/s10980-013-9927-4

Halofsky, J. S., Halofsky, J. E., Burcsu, T., \& Hemstrom, M. A. (2014). Dry forest resilience varies under simulated climate-management scenarios in a central Oregon, USA landscape. Ecological Applications, 24(8), 1908-1925.

Heyerdahl, E. K. (1997). Spatial and temporal variation in historical fire regimes of the Blue Mountains, Oregon and Washington: The influence of climate (Doctoral dissertation). University of Washington, Seattle, WA. Retrieved from https://dlib.lib.washington.edu/researchworks/bitstream/handle/1773/5575/98 19247.pdf?sequence $=1$

Heyerdahl, E. K., \& Agee, J. K. (1996). Historical fire regimes of four sites in the Blue Mountains, Oregon and Washington (Final Report) (p. 173). Seattle, WA: College of Forest Resources, University of Washington. Retrieved from http://www.fs.fed.us/rm/pubs/rmrs_gtr292/2001_powell.pdf

Heyerdahl, E. K., Brubaker, L. B., \& Agee, J. K. (2001). Spatial controls of historical fire regimes: A multiscale example from the interior west, USA. Ecology, 82(3), 660. https://doi.org/10.2307/2680187

Heyerdahl, E. K., Brubaker, L. B., \& Agee, J. K. (2002). Annual and decadal climate forcing of historical fire regimes in the interior Pacific Northwest, USA. The Holocene, 12(5), 597-604. https://doi.org/10.1191/0959683602hl570rp

Johnson, M. C., Kennedy, M. C., \& Peterson, D. L. (2011). Simulating fuel treatment effects in dry forests of the western United States: Testing the principles of a fire-safe forest. Canadian Journal of Forest Research, 41, 1018-1030. https://doi.org/10.1139/X11-032

Johnston, J. D., Bailey, J. D., \& Dunn, C. J. (2016). Influence of fire disturbance and biophysical heterogeneity on pre-settlement ponderosa pine and mixed conifer forests. Ecosphere, 7(11), e01581. https://doi.org/10.1002/ecs2.1581

Kim, Y.-H., Bettinger, P., \& Finney, M. (2009). Spatial optimization of the pattern of fuel management activities and subsequent effects on simulated wildfires. European Journal of Operational Research, 197(1), 253-265. https://doi.org/10.1016/j.ejor.2008.05.025

Krawchuk, M. A., \& Moritz, M. A. (2011). Constraints on global fire activity vary across a resource gradient. Ecology, 92(1), 121-132.

Kretchun, A. M., Loudermilk, E. L., Scheller, R. M., Hurteau, M. D., \& Belmecheri, S. (2016). Climate and bark beetle effects on forest productivity-linking 
dendroecology with forest landscape modeling. Canadian Journal of Forest Research, 46(8), 1026-1034.

Kretchun, A. M., Scheller, R. M., Lucash, M. S., Clark, K. L., Hom, J., \& Van Tuyl, S. (2014). Predicted effects of gypsy moth defoliation and climate change on forest carbon dynamics in the New Jersey Pine Barrens. PLOS ONE, 9(8), e102531. https://doi.org/10.1371/journal.pone.0102531

Krofcheck, D. J., Hurteau, M. D., Scheller, R. M., \& Loudermilk, E. L. (2017a). Prioritizing forest fuels treatments based on the probability of high-severity fire restores adaptive capacity in Sierran forests. Global Change Biology. https://doi.org/10.1111/gcb.13913

Krofcheck, D. J., Hurteau, M. D., Scheller, R. M., \& Loudermilk, E. L. (2017b). Restoring surface fire stabilizes forest carbon under extreme fire weather in the Sierra Nevada. Ecosphere, 8(1), 1-13. https://doi.org/10.1002/ecs2.1663

Littell, J. S., McKenzie, D., Peterson, D. L., \& Westerling, A. L. (2009). Climate and wildfire area burned in western U.S. ecoprovinces, 1916-2003. Ecological Applications, 19(4), 1003-1021.

Loudermilk, E. L., Scheller, R. M., Weisberg, P. J., \& Kretchun, A. (2017). Bending the carbon curve: Fire management for carbon resilience under climate change. Landscape Ecology, 32(7), 1461-1472. https://doi.org/10.1007/s10980-0160447-x

Loudermilk, E. L., Stanton, A., Scheller, R. M., Dilts, T. E., Weisberg, P. J., Skinner, C., \& Yang, J. (2014). Effectiveness of fuel treatments for mitigating wildfire risk and sequestering forest carbon: A case study in the Lake Tahoe Basin. Forest Ecology and Management, 323, 114-125.

Lucash, M. S., Scheller, R. M., J. Gustafson, E., \& R. Sturtevant, B. (2017). Spatial resilience of forested landscapes under climate change and management. Landscape Ecology, 32(5), 953-969. https://doi.org/10.1007/s10980-017-0501-3

Lucash, M. S., Scheller, R. M., Kretchun, A. M., Clark, K. L., \& Hom, J. (2014). Impacts of fire and climate change on long-term nitrogen availability and forest productivity in the New Jersey Pine Barrens. Canadian Journal of Forest Research, 44(5), 404412. https://doi.org/10.1139/cjfr-2013-0383

Maurer, E. P., Wood, A. W., Adam, J. C., Lettenmaier, D. P., \& Nijssen, B. (2002). A longterm hydrologically based dataset of land surface fluxes and states for the conterminous United States. Journal of Climate, 15(22), 3237-3251.

Mclver, J. D., Stephens, S. L., Agee, J. K., Barbour, J., Boerner, R. E. J., Edminster, C. B., ... Zack, S. (2013). Ecological effects of alternative fuel-reduction treatments: 
Highlights of the National Fire and Fire Surrogate study (FFS). International Journal of Wildland Fire, 22(1), 63. https://doi.org/10.1071/WF11130

Monitoring Trends in Burn Severity. (2017, July). Retrieved September 17, 2017, from https://www.mtbs.gov/

NIFC. (2016). Fire Info. Retrieved May 11, 2016, from https://www.nifc.gov/firelnfo/firelnfo_statistics.html

NOAA. (2016). 1981-2010 US Normals Data. Retrieved April 11, 2016, from http://gis.ncdc.noaa.gov/map/viewer/\#app=cdo\&cfg=cdo\&theme=normals\&laye $r s=01 \&$ node=gis\&extent $=-149.3: 20.2:-60.1: 69.6 \&$ custom $=$ normals

NOAA, C. P. C. (2005). Climate Prediction Center - North American Winter Features. Retrieved October 5, 2015, from http://www.cpc.ncep.noaa.gov/products/analysis_monitoring/ensocycle/nawint er.shtml

North, M. P., Stephens, S. L., Collins, B. M., Agee, J. K., Aplet, G., Franklin, J. F., \& Fulé, P. Z. (2015). Reform forest fire management: Agency incentives undermine policy effectiveness. Science, 349(6254), 1280-1281. https://doi.org/10.1126/science.aab2356

Parton, W., Ojima, D., \& Kirchner, T. (1993). Observations and modeling of biomass and soil organic matter dynamics for the grassland biome worldwide. Global Biogeochemical Cycles, 7(4), 785-809.

Prichard, S. J., \& Kennedy, M. C. (2014). Fuel treatments and landform modify landscape patterns of burn severity in an extreme fire event. Ecological Applications, 24(3), 571-590.

Prichard, S. J., Peterson, D. L., \& Jacobson, K. (2010). Fuel treatments reduce the severity of wildfire effects in dry mixed conifer forest, Washington, USA. Canadian Journal of Forest Research, 40(8), 1615-1626. https://doi.org/10.1139/X10-109

Rhodes, J. J., \& Baker, W. L. (2008). Fire probability, fuel treatment effectiveness and ecological tradeoffs in western U.S. public forests. The Open Forest Science Journal, 1(1), 1-7.

Safford, H. D., Stevens, J. T., Merriam, K., Meyer, M. D., \& Latimer, A. M. (2012). Fuel treatment effectiveness in California yellow pine and mixed conifer forests. Forest Ecology and Management, 274, 17-28. https://doi.org/10.1016/j.foreco.2012.02.013

Scheller, R. M., Domingo, J. B., Sturtevant, B. R., Williams, J. S., Rudy, A., Gustafson, E. J., \& Mladenoff, D. J. (2007). Design, development, and application of LANDIS-II, a spatial landscape simulation model with flexible temporal and spatial resolution. 
Ecological Modelling, 201(3-4), 409-419.

https://doi.org/10.1016/j.ecolmodel.2006.10.009

Scheller, R. M., Van Tuyl, S., Clark, K., Hayden, N. G., Hom, J., \& Mladenoff, D. J. (2008).

Simulation of forest change in the New Jersey Pine Barrens under current and pre-colonial conditions. Forest Ecology and Management, 255(5-6), 1489-1500. https://doi.org/10.1016/j.foreco.2007.11.025

Schwilk, D. W., Keeley, J. E., Knapp, E. E., Mclver, J., Bailey, J. D., Fettig, C. J., ... Outcalt, K. W. (2009). The National Fire and Fire Surrogate study: Effects of fuel reduction methods on forest vegetation structure and fuels. Ecological Applications, 19(2), 285-304.

Smith, J. E., McKay, D., Niwa, C. G., Thies, W. G., Brenner, G., \& Spatafora, J. W. (2004). Short-term effects of seasonal prescribed burning on the ectomycorrhizal fungal community and fine root biomass in ponderosa pine stands in the Blue Mountains of Oregon. Canadian Journal of Forest Research, 34(12), 2477-2491. https://doi.org/10.1139/x04-124

Stephens, S. L., Mclver, J. D., Boerner, R. E. J., Fettig, C. J., Fontaine, J. B., Hartsough, B. R., ... Schwilk, D. W. (2012). The effects of forest fuel-reduction treatments in the United States. BioScience, 62(6), 549-560. https://doi.org/10.1525/bio.2012.62.6.6

Stephens, S. L., \& Moghaddas, J. J. (2005). Experimental fuel treatment impacts on forest structure, potential fire behavior, and predicted tree mortality in a California mixed conifer forest. Forest Ecology and Management, 215(1-3), 2136. https://doi.org/10.1016/j.foreco.2005.03.070

Sturtevant, B. R., Miranda, B. R., Scheller, R. M., Shinneman, D., \& Kretchun, A. M. (unpublished). LANDIS-II Dynamic Fire System v3 User Guide.

Sturtevant, B. R., Scheller, R. M., Miranda, B. R., Shinneman, D., \& Syphard, A. (2009). Simulating dynamic and mixed-severity fire regimes: A process-based fire extension for LANDIS-II. Ecological Modelling, 220(23), 3380-3393. https://doi.org/10.1016/j.ecolmodel.2009.07.030

Swanson, D. K., Schmitt, C. L., Shirley, D. M., Erickson, V., Schuetz, K. J., Tatum, M. L., \& Powell, D. C. (2010). Aspen biology, community classification, and management in the Blue Mountains (Gen. Tech. Rep. No. PNW-GTR-806) (p. 117). Portland, OR: U.S. Department of Agriculture, Forest Service, Pacific Northwest Research Station. 
Swezy, D. M., \& Agee, J. K. (1991). Prescribed-fire effects on fine-root and tree mortality in old-growth ponderosa pine. Canadian Journal of Forest Research, 21, 626634.

Syphard, A. D., Keeley, J. E., \& Brennan, T. J. (2011). Comparing the role of fuel breaks across southern California national forests. Forest Ecology and Management, 261(11), 2038-2048. https://doi.org/10.1016/j.foreco.2011.02.030

Syphard, A. D., Scheller, R. M., Ward, B. C., Spencer, W. D., \& Strittholt, J. R. (2011). Simulating landscape-scale effects of fuels treatments in the Sierra Nevada, California, USA. International Journal of Wildland Fire, 20(3), 364. https://doi.org/10.1071/WF09125

USDA Forest Service. (2012). Increasing the pace of restoration and job creation on our National Forests. Washington, DC: US Department of Agriculture Forest Service. Retrieved from http://www.fs.fed.us/sites/default/files/increasing-pacerestoration-job-creation-2012.pdf

USDA Forest Service, Malheur National Forest. (2015). CFLR and Partnerships. Retrieved October 7, 2015, from http://www.fs.usda.gov/detailfull/malheur/workingtogether/partnerships/?cid= STELPRDB5244635\&width=full

Westerling, A. L., Hidalgo, H. G., Cayan, D. R., \& Swetnam, T. W. (2006). Warming and earlier spring increase western U.S. forest wildfire activity. Science, 313, 940943. https://doi.org/10.1126/science.1130691

Whitlock, C. (2003). The role of climate and vegetation change in shaping past and future fire regimes in the northwestern US and the implications for ecosystem management. Forest Ecology and Management., 178(1), 5.

Williams, J. W., \& Jackson, S. T. (2007). Novel climates, no-analog communities, and ecological surprises. Frontiers in Ecology and the Environment, 5(9), 475-482. https://doi.org/10.1890/070037

Zarnoch, S. J., Blake, J. I., \& Parresol, B. R. (2014). Are prescribed fire and thinning dominant processes affecting snag occurrence at a landscape scale? Forest Ecology and Management, 331, 144-152. https://doi.org/10.1016/j.foreco.2014.08.007 


\section{Chapter 4 References}

Allen, G. M., \& Gould, E. M., Jr. (1986). Complexity, wickedness, and public forests. Journal of Forestry, 20-23.

Brown, G. G., \& Donovan, S. (2013). Escaping the national forest planning quagmire: Using public participation GIS to assess acceptable national forest use. Journal of Forestry, 111(2), 115-125. https://doi.org/10.5849/jof.12-087

Brown, G. G., \& Pullar, D. V. (2012). An evaluation of the use of points versus polygons in public participation geographic information systems using quasi-experimental design and Monte Carlo simulation. International Journal of Geographical Information Science, 26(2), 231-246. https://doi.org/10.1080/13658816.2011.585139

Brown, G. G., \& Reed, P. (2009). Public participation GIS: A new method for use in national forest planning. Forest Science, 55(2), 166-182.

Butler, W. H., Monroe, A., \& McCaffrey, S. (2015). Collaborative implementation for ecological restoration on US public lands: Implications for legal context, accountability, and adaptive management. Environmental Management, 55(3), 564-577. https://doi.org/10.1007/s00267-014-0430-8

Calkin, D. E., Gebert, K. M., Jones, J. G., \& Neilson, R. P. (2005). Forest Service large fire area burned and suppression expenditure trends, 1970-2002. Journal of Forestry, 103(4), 179-183.

Donovan, S. M., Looney, C., Hanson, T., Sanchez de Leon, Y., Wulfhorst, J. D., Eigenbrode, S. D., ... Bosque Perez, N. A. (2009). Reconciling social and biological needs in an endangered ecosystem: The Palouse as a model for bioregional planning. Ecology and Society, 14(1), 9.

Duveneck, M. J., Scheller, R. M., \& White, M. A. (2014). Effects of alternative forest management on biomass and species diversity in the face of climate change in the northern Great Lakes region (USA). Canadian Journal of Forest Research, 44(7), 700-710. https://doi.org/10.1139/cjfr-2013-0391

Goodman, L. A. (1961). Snowball sampling. The Annals of Mathematical Statistics, 148170.

Gordon, J. S., Matarrita-Cascante, D., Stedman, R. C., \& Luloff, A. E. (2010). Wildfire perception and community change. Rural Sociology, 75(3), 455-477. https://doi.org/10.1111/j.1549-0831.2010.00021.x

Hamilton, L. C., Hartter, J., Keim, B. D., Boag, A. E., Palace, M. W., Stevens, F. R., \& Ducey, M. J. (2016). Wildfire, climate, and perceptions in Northeast Oregon. 
Regional Environmental Change, 16(6), 1819-1832.

https://doi.org/10.1007/s10113-015-0914-y

Harney County Restoration Collaborative. (2016). About HCRC: Our story. Retrieved May 10, 2016, from http://highdesertpartnership.org/what-we-do/harney-countyrestoration-collaborative/about-hcrc/

Hartter, J. N., Stevens, F. R., Hamilton, L. C., Oester, P. T., Congalton, R. G., Ducey, M. J., \& Crowley, M. A. (2014). Forest management and wildfire risk in Inland Northwest: Survey of landowners' concerns about public land management in northeastern Oregon (No. National Issue Brief \#70). Durham, NH: Carsey Institute, University of New Hampshire. Retrieved from http://scholars.unh.edu/carsey/211/

Hartter, J., Stevens, F. R., Hamilton, L. C., Congalton, R. G., Ducey, M. J., \& Oester, P. T. (2015). Modelling associations between public understanding, engagement and forest conditions in the Inland Northwest, USA. PLOS ONE, 10(2), e0117975. https://doi.org/10.1371/journal.pone.0117975

Jennings, M. (2013). Climate disruption: Are we beyond the worst case scenario? Global Policy, 4(1), 32-42. https://doi.org/10.1111/j.1758-5899.2012.00193.x

Kretchun, A. M., Loudermilk, E. L., Scheller, R. M., Hurteau, M. D., \& Belmecheri, S. (2016). Climate and bark beetle effects on forest productivity-linking dendroecology with forest landscape modeling. Canadian Journal of Forest Research, 46(8), 1026-1034.

Kretchun, A. M., Scheller, R. M., Lucash, M. S., Clark, K. L., Hom, J., \& Van Tuyl, S. (2014). Predicted effects of gypsy moth defoliation and climate change on forest carbon dynamics in the New Jersey Pine Barrens. PLOS ONE, 9(8), e102531. https://doi.org/10.1371/journal.pone.0102531

Kreuger, L. W., \& Neuman, W. L. (2006). Social work research methods: Qualitative and quantitative applications. Boston, MA: Pearson Education, Inc.

Littell, J. S., McKenzie, D., Peterson, D. L., \& Westerling, A. L. (2009). Climate and wildfire area burned in western U.S. ecoprovinces, 1916-2003. Ecological Applications, 19(4), 1003-1021.

Loudermilk, E. L., Scheller, R. M., Weisberg, P. J., \& Kretchun, A. (2017). Bending the carbon curve: Fire management for carbon resilience under climate change. Landscape Ecology, 32(7), 1461-1472. https://doi.org/10.1007/s10980-0160447-x 
Lucash, M. S., Scheller, R. M., J. Gustafson, E., \& R. Sturtevant, B. (2017). Spatial resilience of forested landscapes under climate change and management. Landscape Ecology, 32(5), 953-969. https://doi.org/10.1007/s10980-017-0501-3

Lucash, M. S., Scheller, R. M., Kretchun, A. M., Clark, K. L., \& Hom, J. (2014). Impacts of fire and climate change on long-term nitrogen availability and forest productivity in the New Jersey Pine Barrens. Canadian Journal of Forest Research, 44(5), 404412. https://doi.org/10.1139/cjfr-2013-0383

McBride, B. B., Sanchez-Trigueros, F., Carver, S. J., Watson, A. E., Stumpff, L. M., Matt, R., \& Borrie, W. T. (2017). Participatory geographic information systems as an organizational platform for the integration of traditional and scientific knowledge in contemporary fire and fuels management. Journal of Forestry, 115(1), 43-50.

McCaffrey, S., Toman, E., Stidham, M., \& Shindler, B. (2013). Social science research related to wildfire management: An overview of recent findings and future research needs. International Journal of Wildland Fire, 22(1), 15. https://doi.org/10.1071/WF11115

Morse, W. C., Lowery, D. R., \& Steury, T. (2014). Exploring saturation of themes and spatial locations in qualitative public participation geographic information systems research. Society \& Natural Resources, 27(5), 557-571. https://doi.org/10.1080/08941920.2014.888791

Nielsen-Pincus, M., Goldberg, C. S., Pocewicz, A., Force, J. E., Waits, L. P., Morgan, P., \& Vierling, L. (2010). Predicted effects of residential development on a northern Idaho landscape under alternative growth management and land protection policies. Landscape and Urban Planning, 94(3-4), 255-263.

https://doi.org/10.1016/j.landurbplan.2009.10.011

O'Hara, K. L. (2005). Multiaged silviculture of ponderosa pine. In M. W. Ritchie, D. A. Maquire, \& A. Youngblood (Eds.), Proceedings of the Symposium on Ponderosa Pine: Issues, Trends, and Management, Gen. Tech. Rep. PSW-GTR-198 (p. 59). Klamath Falls, Oregon: Albany CA: Pacific Southwest Research Station, USDA Forest Service.

Pachauri, R. K., Allen, M. R., Barros, V. R., Broome, J., Cramer, W., Christ, R., ... others. (2014). Climate change 2014: Synthesis report. Contribution of Working Groups I, II and III to the Fifth Assessment Report of the Intergovernmental Panel on Climate Change. IPCC. Retrieved from http://epic.awi.de/37530/ 
Radeloff, V. C., Hammer, R. B., Stewart, S. I., Fried, J. S., Holcomb, S. S., \& McKeefry, J. F. (2005). The wildland-urban interface in the United States. Ecological Applications, 15(3), 799-805.

Rittel, H. W., \& Webber, M. M. (1973). Dilemmas in a general theory of planning. Policy Sciences, 4, 155-169.

Scheller, R. M., Domingo, J. B., Sturtevant, B. R., Williams, J. S., Rudy, A., Gustafson, E. J., \& Mladenoff, D. J. (2007). Design, development, and application of LANDIS-II, a spatial landscape simulation model with flexible temporal and spatial resolution. Ecological Modelling, 201(3-4), 409-419.

https://doi.org/10.1016/j.ecolmodel.2006.10.009

Scheller, R. M., Van Tuyl, S., Clark, K., Hayden, N. G., Hom, J., \& Mladenoff, D. J. (2008). Simulation of forest change in the New Jersey Pine Barrens under current and pre-colonial conditions. Forest Ecology and Management, 255(5-6), 1489-1500. https://doi.org/10.1016/j.foreco.2007.11.025

Schlossberg, M., \& Shuford, E. (2005). Delineating "public" and "participation" in PPGIS. URISA Journal, 16, 15-26.

Shindler, B., \& Reed, M. (1996). Forest management in the Blue Mountains: Public perspectives on prescribed fire and mechanical thinning (Research Report) ( $p$. 74). Corvalis, OR: Oregon State University, Department of Forest Resources. Retrieved from http://www.fs.fed.us/pnw/pubs/journals/pnw_1996_Shindler001.pdf

Shindler, B., \& Toman, E. (2003). Fuel reduction strategies in forest communities: A longitudinal analysis of public support. Journal of Forestry, 101(6), 8-15.

Southern Blues Restoration Coalition. (2015). Southern Blues Restoration Coalition CFLRP Annual Report: 2015 (Annual Report). Malheur National Forest, OR.

Strickland-Munro, J., Moore, S., Kobryn, H., \& Palmer, D. (2015). Values and aspirations for coastal waters of the Kimberley: Social values and participatory mapping using interviews. Technical Report. Kimberley Marine Research Program Node of the Western Australian Marine Science Institution (Technical Progress Report). Perch, Australia: Murdoch University, Western Australia Marine Science Institution. Retrieved from http://researchrepository.murdoch.edu.au/25482/

Sustainable Northwest. (2015). Blue Mountains Forest Partners. Retrieved October 6, 2015, from http://www.sustainablenorthwest.org/what-we-do/successstories/blue-mountain-forest-partners

Theobald, D. M. (2001). Land-use dynamics beyond the American urban fringe. Geographical Review, 91(3), 544-564. 
US Census Bureau. (2016). Population. Retrieved April 20, 2016, from http://www.census.gov/topics/population.html

U.S. EPA. (2017, February 6). How citizens can comment and participate in the National Environmental Policy Act process. Retrieved from https://www.epa.gov/nepa/how-citizens-can-comment-and-participatenational-environmental-policy-act-process

USDA Forest Service. (2016a). Blue Mountains Forest Resiliency Project. Retrieved from https://www.fs.usda.gov/detail/r6/landmanagement/resourcemanagement/?cid $=$ stelprd3852678

USDA Forest Service. (2016b). Blue Mountains Forest Resiliency Project: Blue Mountains Restoration Strategy, June 2016. USDA Forest Service. Retrieved from https://www.fs.usda.gov/Internet/FSE_DOCUMENTS/fseprd506510.pdf

USDA Forest Service, Malheur National Forest. (2015). CFLR and Partnerships. Retrieved October 7, 2015, from http://www.fs.usda.gov/detailfull/malheur/workingtogether/partnerships/?cid= STELPRDB5244635\&width=full

Westerling, A. L., Hidalgo, H. G., Cayan, D. R., \& Swetnam, T. W. (2006). Warming and earlier spring increase western U.S. forest wildfire activity. Science, 313, 940943. https://doi.org/10.1126/science.1130691

Youngblood, A. (2005). Silvicultural systems for managing ponderosa pine. In M. W. Ritchie, D. A. Maguire, \& A. Youngblood (Eds.), Proceedings of the Symposium on Ponderosa Pine: Issues, Trends, and Management. Klamath Falls, Oregon: Albany CA: Pacific Southwest Research Station, USDA Forest Service. 


\section{Appendices}

\section{Appendix A. Supplemental material}

All input files for the LANDIS-II model and all code used to analyze output data are freely available online at https://github.com/brookecassell/Project-

Malheur Fuels Treatment.git Software needed to utilize these inputs are R and LANDIS-

II. 


\title{
Appendix B. Institutional Review Board Approval
}

\section{巴P Portland State}

\author{
Post Office Box $751 \quad 503-725-2227$ tel \\ Portland, Oregon 97207-0751 503-725-8170 fax \\ Human Subjects Research Review Committee \\ hsrrcịpdx.edu \\ Date: August 15, 2016 \\ To: Robert Scheller/Brooke Cassell
}

From: Karen Cellarius, HSRRC Chair

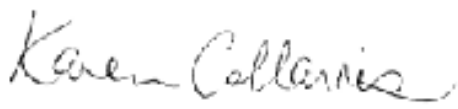

Re: HSRRC approval for your project tifled, "Assessing stakeholder preferences for fuel treatments in the southern Blue Mountains, Oregon" HSRRC Proposal \# 163897

Approval-Expiration: Angust 15,2016-August 14,2017

Review Type: Expedited, Categories 6,7

In accordance with your request, the PSU Human Subjects Research Review Committee has reviewed your request for approval of the project referenced above for compliance with PSU and DHHS policies and regulations covering the protection of human subjects. The Committee is satisfied that your provisions for protecting the rights and welfare of all subjects participating in the research are adequate, and your project is approved. Please note the following requirements:

Approval: You are approved to conduct this research study only during the period of approval cited above; and the research must be conducted according to the plans and protocol submitted (approved copy enclosed).

Consent: Signed consent is required from all participants in this study

Changes to Protocol: Any changes in the proposed study, whether to procedures, survey instruments, consent forms or cover letters, must be outlined and submitted to the Committee immediately. The proposed changes cannot be implemented before they have been reviewed and approved by the Committee

Continuing Review: This approval will expire on 08/14/2017. It is the investigator's responsibility to ensure that a Continuing Review Report on the status of the project is submitted to the HSRRC two months before the expiration date, and that approval of the study is kept current. The IRB offices does not send out notifications of expiration dates. The Continuing Review Report is available at www.rsp.pdx.edu/compliance_human.php and in the Office of Research and Strategic Partmerships (RSP).

Adverse Reactions and/or Unanticipated Problems: If any adverse reactions or unanticipated problems occur as a result of this study, you are required to notify the Office of Research Integrity within 5 days of the event. If the issue is serious, approval may be withdrawn pending an investigation by the Committee.

Completion of Study: Please notify the Committee as soon as your research has been completed. Study records, including protocols and signed consent forms for each participant, must be kept by the investigator in a secure location for three years following completion of the study (or per any requirements specified by the project's funding agency).

If you have questions or concerns, please contact the Office of Research Integrity in the PSU RSP at 503-725-2227. 


\title{
Appendix C. Focus group and participatory mapping materials
}

\section{C.1 Informed consent cover letter for anonymous questionnaire}

\author{
Assessing Stakeholder Preferences for Fuel Treatments in the Southern Blue \\ Mountains, Oregon
}

You are being asked to participate in a research study that is being done by Robert Scheller, who is the Principal Investigator and Brooke Cassell, who is the Graduate Student Investigator, from the Department of Environmental Science and Management, at Portland State University in Portland, Oregon. This study is part of the $\mathrm{PhD}$ dissertation research of Brooke Cassell. The purpose of the study is to better understand how stakeholders in the management of the Southern Blue Mountains, OR region view fuel treatments and what their spatial preferences are for fuel treatment placement on the landscape. You are being invited to participate in this study because you have expressed an interest in how forested lands are managed in the Southern Blue Mountains, Oregon. Funding for this project is from the Joint Fire Science Program Project \#14-1-01-2 and an Edward D. and Olive C. Bushby Scholarship from Portland State University for graduate student research.

Your participation will involve completing the following questionnaire. The questionnaire should take about 30 minutes to complete. Your involvement in the study is voluntary, and you may choose not to participate. You can decline to answer any of the questions at any time and for any reason. There are no known risks in this study, but some individuals may experience discomfort when answering questions. There are no costs to you for participating in this research.

This questionnaire is anonymous. If you choose to complete the questionnaire on paper and mail it to the researchers, your questionnaire will be transcribed to an electronic spreadsheet and the paper copy destroyed. If you choose to complete the questionnaire online, we will not collect your computer's IP address or link your personal information to your answers, however, absolute anonymity cannot be guaranteed over the internet. All data will be kept for 3 years in a password protected computer in Cassell's office and then destroyed. No one will be able to identify you or your answers, and no one will know whether or not you participated in the study. Individuals from the Institutional Review Board may inspect these records.

There will be no direct benefits to you for participating in this research, but results of this study should provide more general benefits. The findings from this project will provide information on how different stakeholders view fuel treatments, and how fuel treatments that reflect stakeholder preferences may compare with other types of fuel treatment 
placement at reducing wildfire activity. If published, results will be presented in summary form only, and no individual information will be disclosed. If you wish, you may provide your email address to which you will be sent a web address where you can access the summary results of this research.

If you have any questions about this research project, please contact Brooke Cassell at (815) 814-2260. If you have questions regarding your legal rights as a research subject, you may contact:

PSU Institutional Review Board

Office of Research Integrity

1600 SW $4^{\text {th }}$ Ave., Market Center Building, Ste. 620

Portland, OR 97201

(503) 725-2227 or 1 (877) 480-4400.

Thank you for your participation.

Sincerely,

Brooke Cassell

$\mathrm{PhD}$ Student

Portland State University

Environmental Science and Management

Your participation in this questionnaire is voluntary. By completing this questionnaire/returning this questionnaire, you will be agreeing to participate in the above described research study.

Optional: If you wish to view the summarized research results, please provide your email address here. If you choose to provide your email address, it will be kept in a passwordprotected spreadsheet on a password-protected computer in a locked office. After you are contacted with the summarized research results, we will delete your email address from our database. Your email address will not be shared with any other entity, nor will it be used for any purpose other than that stated here.

Email Address 


\section{C.2 Questionnaire}

\section{ASSESSING STAKEHOLDER PREFERENCES FOR FUEL TREATMENTS IN THE SOUTHERN BLUE MOUNTAINS, OREGON}

We are asking you for your help with a research project that aims to understand stakeholder perceptions about fuel treatments and preferences for types and locations of fuel treatments in the Southern Blue Mountains in Oregon. We would like your feedback specifically related to the area shown on the map, which includes the portions of the Malheur and Wallowa-Whitman National Forests and the land immediately surrounding them south of US Route 26 and north of US Route 20.

The study involves completing a questionnaire followed by participating in a focus group and mapping activity. The focus groups will be held in mid- to late-October, 2016. Insights from this questionnaire will help improve our understanding of how different community members utilize public lands and

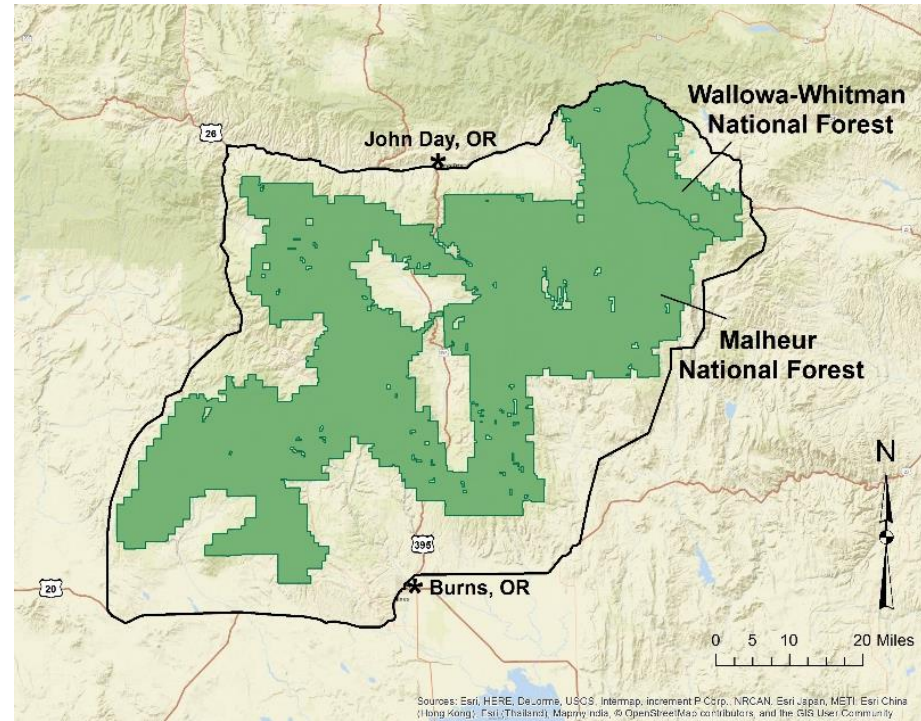

The study area.

will give us insight into stakeholder perceptions of fuel treatments.

You can complete this questionnaire on paper or online. If you choose to complete it online, please do so at this website address:

https://portlandstate.qualtrics.com//SE/?SID=SV_6A1QWIfepmc6STX and enter the password BLUEMOUNTAINS as well as the participant number found at the top righthand corner of this page when prompted. If you choose to complete it on paper, please return the questionnaire to me in the self-addressed, postage-paid envelope enclosed. 
The questionnaire consists of 4 pages in total and should take no more than 30 minutes to complete. If you need additional space to answer any questions, please use the back side of the survey and/or attach additional pages and indicate the number of the question you are answering.

Note that this questionnaire only aims to explore your preferences in land uses and fuel treatments and is not designed as a test of your knowledge about land use or fuel treatments. You may skip any question(s) that you do not wish to answer.

Confidentiality: Your answers are anonymous, and all information will be consolidated. No information gathered will be directly linked to an individual, and any information you provide cannot be used against you in any way.

CONTINUE TO NEXT PAGE 


\section{Questionnaire Begins Here}

1. In 2-3 sentences, please describe your primary relationship with the Malheur National Forest and surrounding areas.

2. What activities do you enjoy in the Malheur National Forest and the surrounding forested areas? These can be work related or recreational. Please be as specific as possible and list as many activities as you can think of.

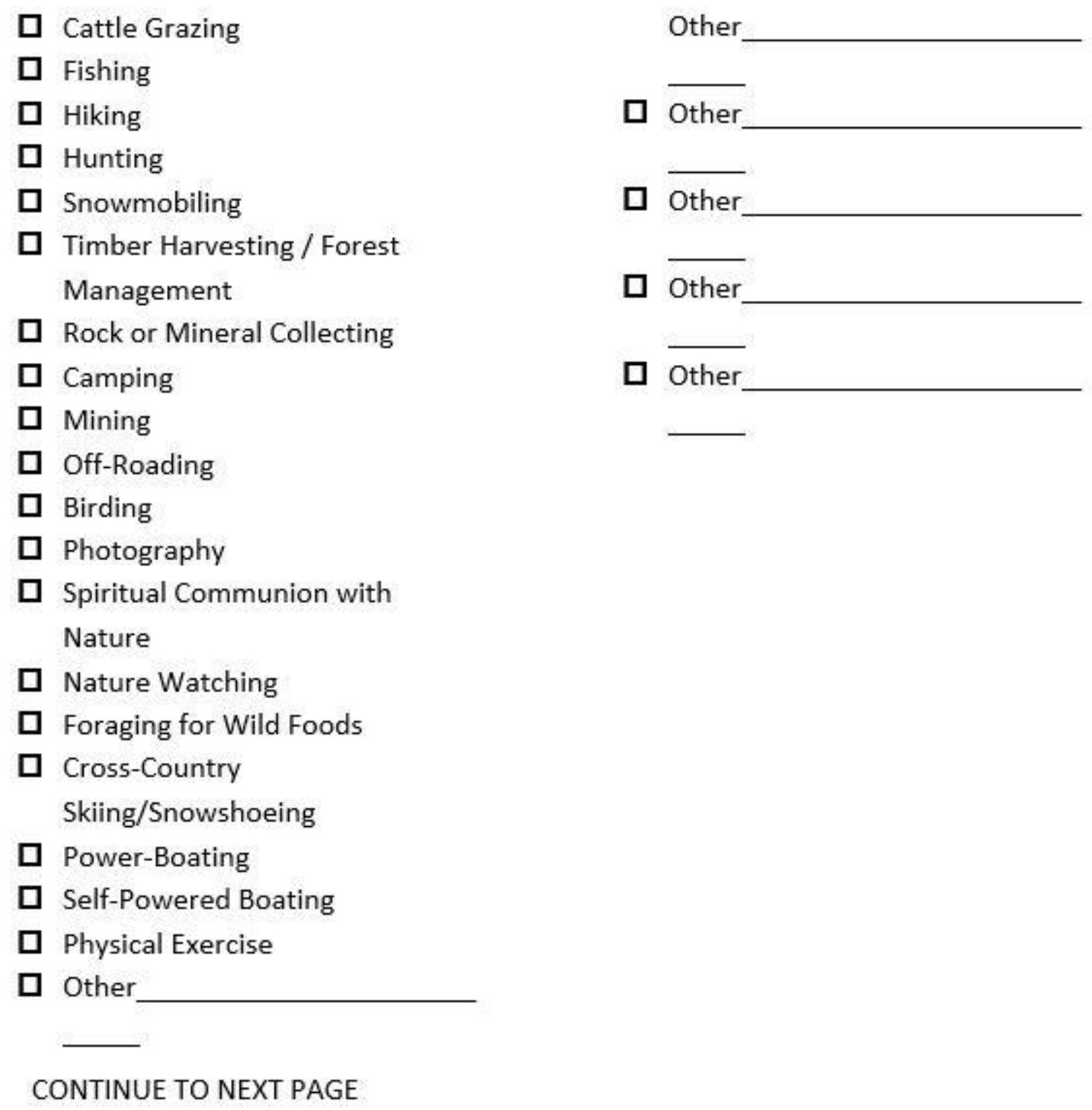


"Fuel treatments" are management actions intended to reduce wildfire activity. They reduce the fuel available to a wildfire, and can prevent the spread of fire from tree to tree and across large areas including areas with homes and other structures. There are different types of fuel treatments, and some of them include light thinning (harvesting only small trees), heavy thinning (harvesting both small and large trees) and prescribed burning (lighting small fires to consume fuels on the ground).

Photos of each treatment type are below:

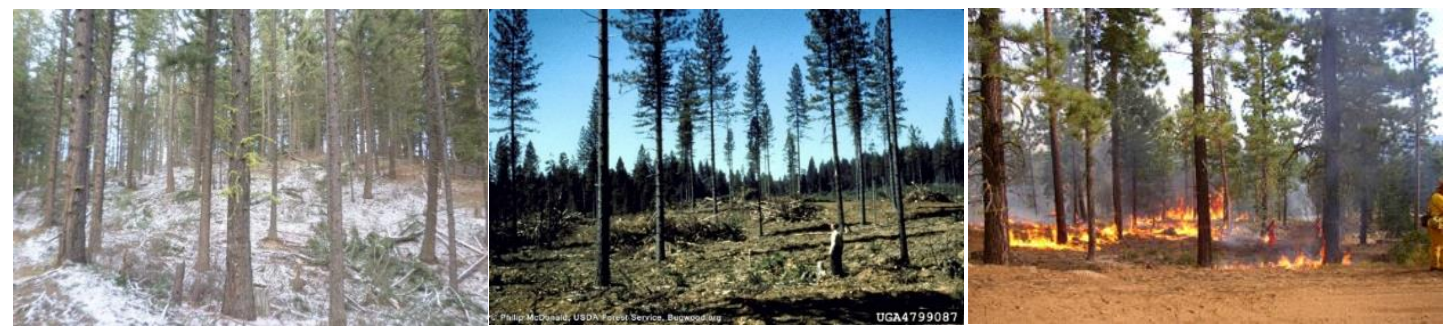

Example of light thinning. Example of heavy thinning. Example of prescribed fire.

3.a. Thinking about these types of fuel treatments, when and where on the landscape do you think that fuel treatments are important?

3.b. Which, if any, of these types of fuel treatments are you willing to see on the Malheur National Forest and the surrounding areas?

\section{CONTINUE TO NEXT PAGE}

3. Wildfires are fires that ignite naturally or accidentally. They consume fuels, and can be considered a "passive fuel treatment" by changing the forest's structure and reducing the amount of fuels available to future fires. In addition, wildfires provide 
some benefits to forested landscapes by making nutrients such as nitrogen available to plants, creating wildlife habitat, and improving forage plants for grazing animals.

When and where on the landscape do you think that fires should be allowed to burn, as long as they do not threaten any homes or other development?

4. How do you believe public input should be incorporated into management of public lands?

5. How well do you think land management agencies do at incorporating public interests in management of public lands?

6. How have your opinions about land management agencies changed over the past several years?

\section{CONTINUE TO NEXT PAGE}

7. Thinking now about community members in Baker, Grant, Crook and Harney

Counties, what are the general opinions about how public input should be incorporated into management of public lands? 
8. How well do community members in Baker, Grant, Crook and Harney Counties think land management agencies do at incorporating public interests in management of public lands?

9. How have general opinions about land management agencies changed over the past several years in Baker, Grant, Crook and Harney Counties?

THIS CONCLUDES THE QUESTIONNAIRE. PLEASE RETURN THE ENTIRE PACKET TO THE RESEARCHERS IN THE SELF-ADDRESSED, POSTAGE-PAID ENVELOPE PROVIDED. IF YOU WISH TO BE NOTIFIED OF THE RESULTS OF THIS STUDY, PLEASE PROVIDE YOUR EMAIL ADDRESS HERE:

THANK YOU FOR YOUR PARTICIPATION. 


\section{C.3 Focus group consent form}

The Portland State University

Consent to Participate in Research

\section{Assessing Stakeholder Preferences for Fuel Treatments in the Southern Blue Mountains, Oregon}

\section{Introduction}

You are being asked to participate in a research study that is being done by Robert Scheller, who is the Principal Investigator and Brooke Cassell, who is the Graduate Student Investigator, from the Department of Environmental Science and Management, at Portland State University in Portland, Oregon. This study is part of the PhD dissertation research of Brooke Cassell. The purpose of the study is to better understand how stakeholders in the management of the Southern Blue Mountains, OR region view fuel treatments and what their spatial preferences are for fuel treatment placement on the landscape. You are being invited to participate in this study because you have expressed an interest in how forested lands are managed in the Southern Blue Mountains, Oregon. Funding for this project is from the Joint Fire Science Program Project \#14-1-01-2 and an Edward D. and Olive C. Bushby Scholarship from Portland State University for graduate student research.

This form will explain the research study, and will also explain the possible risks as well as the possible benefits to you. We encourage you to talk with your family and friends before you decide to take part in this research study. If you have any questions, please ask one of the study investigators.

\section{What will happen if I decide to participate?}

If you agree to participate, the following things will happen:

You will be asked questions about the ways in which you use the landscape in the southern Blue Mountains region and about your views about fuel treatments. You will be asked to draw on maps to illustrate the areas on the landscape where you are willing or not willing to have fuel treatments implemented and to describe the reasons why you feel that way.

The focus group will be recorded using a digital audio recording device. Following the session, the audio will be transcribed into a word processing document, and the audio recording will be destroyed. No names or other identifying information will be included in the transcription.

\section{How long will I be in this study?}

Participation in this study will take a total of 2 hours over a period of 1 day.

What are the risks or side effects of being in this study? 
There are risks of stress, emotional distress, inconvenience and possible loss of privacy and confidentiality associated with participating in a research study.

For more information about risks and discomforts, ask the investigator.

\section{What are the benefits to being in this study?}

There will be no direct benefits to you for participating in this research, but results of this study should provide more general benefits. The findings from this project will provide information on how different stakeholders view fuel treatments, and how fuel treatments that reflect stakeholder preferences may compare with other types of fuel treatment placement at reducing wildfire activity.

\section{How will my information be kept confidential?}

We will take measures to protect the security of all your personal information, but we cannot guarantee confidentiality of all study data. The audio recording will be transcribed, and the transcription will not include your name or any other identifying information. Following transcription, the audio recording will be destroyed. If published, results will be presented in summary form only, and no individual information will be disclosed.

Participation in a focus group does not allow for the same level of confidentiality as other forms of research. The investigator can only be responsible for the confidentiality of the data collected by that investigator, and confidentiality may be breached by others in the focus group. As a participant in the focus group, you are encouraged not to speak of what was discussed during the group once the group has ended.

Information contained in your study records is used by study staff. The Portland State University Institutional Review Board (IRB) that oversees human subject research and/or other entities may be permitted to access your records, and there may be times when we are required by law to share your information. It is the investigator's legal obligation to report child abuse, child neglect, elder abuse, harm to self or others or any life-threatening situation to the appropriate authorities, and; therefore, your confidentiality will not be maintained.

Your name will not be used in any published reports about this study.

\section{Will I be paid for taking part in this study?}

No. 


\section{Can I stop being in the study once I begin?}

Your participation in this study is completely voluntary. You have the right to choose not to participate or to withdraw your participation at any point in this study without penalty or loss of benefits to which you are otherwise entitled.

\section{Whom can I call with questions or complaints about this study?}

If you have any questions, concerns or complaints at any time about the research study, Brooke Cassell will be glad to answer them at (815) 814-2260.

\section{Whom can I call with questions about my rights as a research participant?}

If you have questions regarding your rights as a research participant, you may call the PSU Office for Research Integrity at (503) 725-2227 or 1 (877) $480-4400$. The ORI is the office that supports the PSU Institutional Review Board (IRB). The IRB is a group of people from PSU and the community who provide independent oversight of safety and ethical issues related to research involving human participants. For more information, you may also access the IRB website at https://sites.google.com/a/pdx.edu/research/integrity.

\section{CONSENT}

You are making a decision whether to participate in this study. Your signature below indicates that you have read the information provided (or the information was read to you). By signing this consent form, you are not waiving any of your legal rights as a research participant.

You have had an opportunity to ask questions and all questions have been answered to your satisfaction. By signing this consent form, you agree to participate in this study and to be recorded by an audio recording device. A copy of this consent form will be provided to you.

Name of Adult Subject (print) Signature of Adult Subject Date

\section{INVESTIGATOR SIGNATURE}

This research study has been explained to the participant and all of his/her questions have been answered. The participant understands the information described in this consent form and freely consents to participate.

Name of Investigator/ Research Team Member (type or print)

(Signature of Investigator/ Research Team Member) Date 


\section{C.4 Introductory presentation to focus group participants}

ASSESSING COMMUNITY PREFERENCES FOR FUEL TREATMENTS IN THE SOUTHERN BLUE MOUNTAINS, OREGON

\section{LINKING LANDSCAPE and SOCIAL PERSPECTIVES}

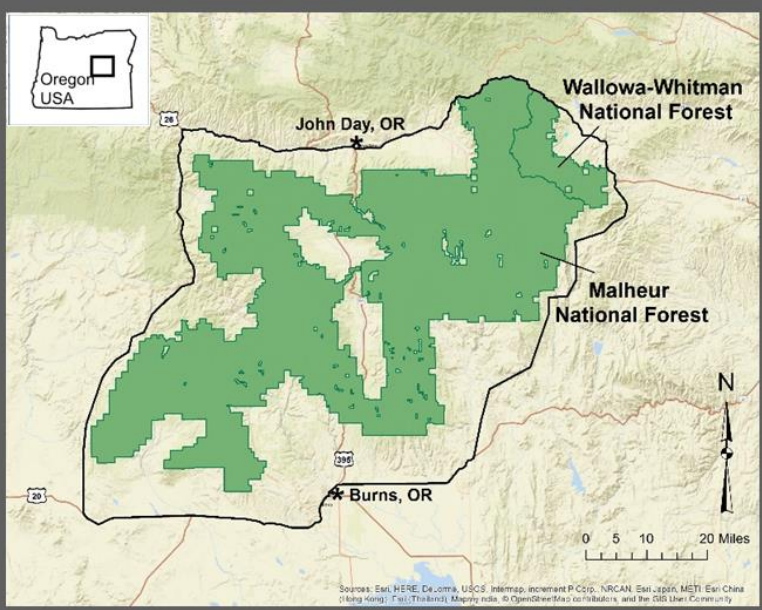




\section{LANDSCAPE MODELING - FUEL TREATMENTS}

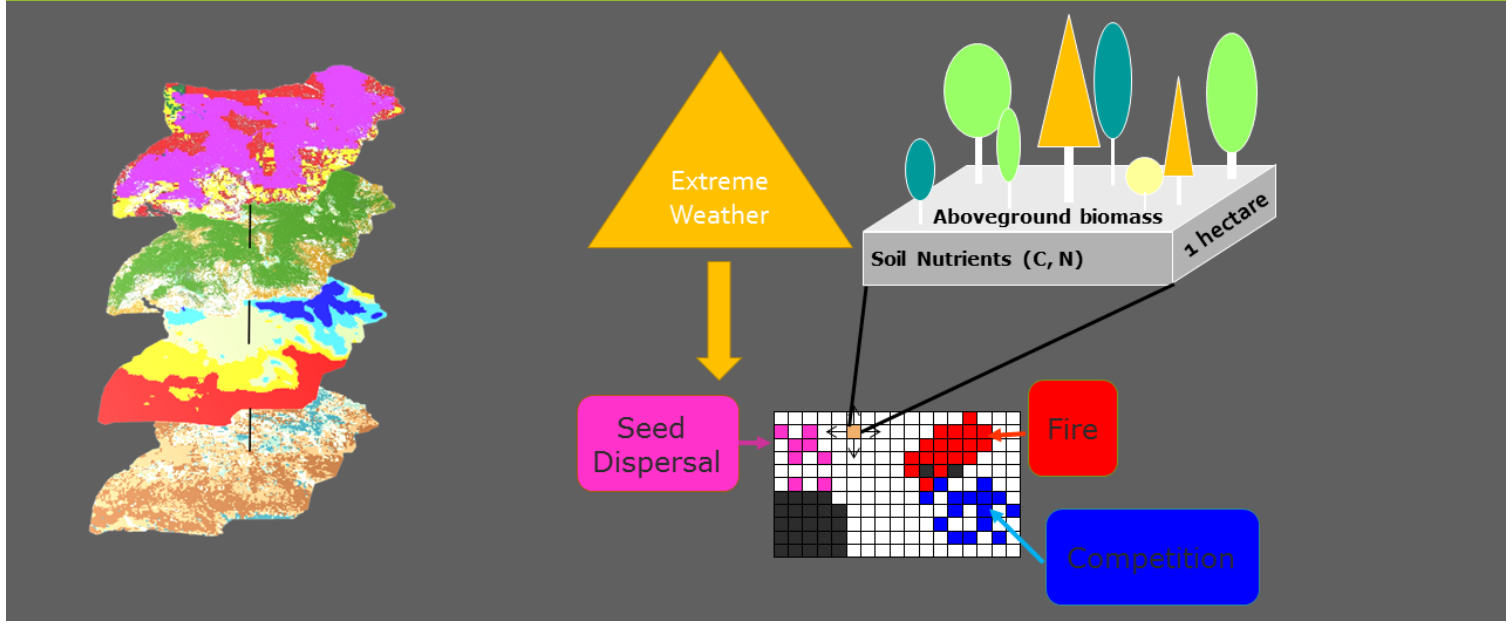

\section{COMMUNITY PREFERENCES - FUEL TREATMENTS}

1. THEMES

- Light Thinning

- HeavyThinning

- Prescribed Fire

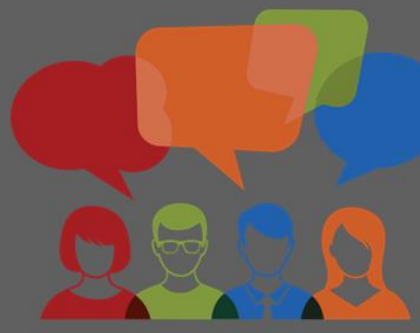

2. MODELING

- Community-Driven Management

- Fire-Modeling-Driven Management 


\section{LIGHT THINNING}

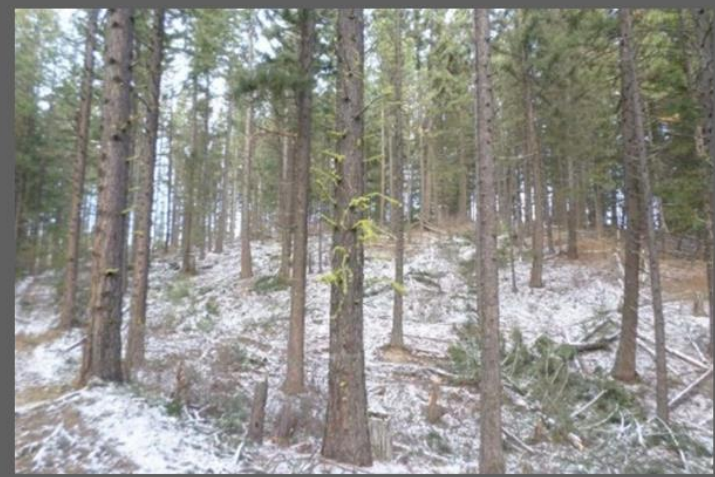

- Cut only small trees (noncommercial)

- Reduce fuels

- Open up the canopy

\section{HEAVY THINNING}

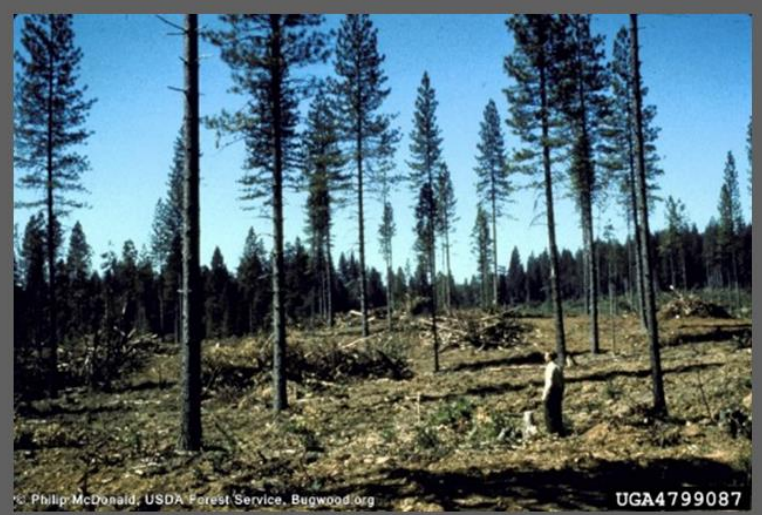

- Cut small and large trees

- Reduce fuels

- Open up the canopy

- Recoup cost / Profit 


\section{PRESCRIBED FIRE (RX FIRE)}

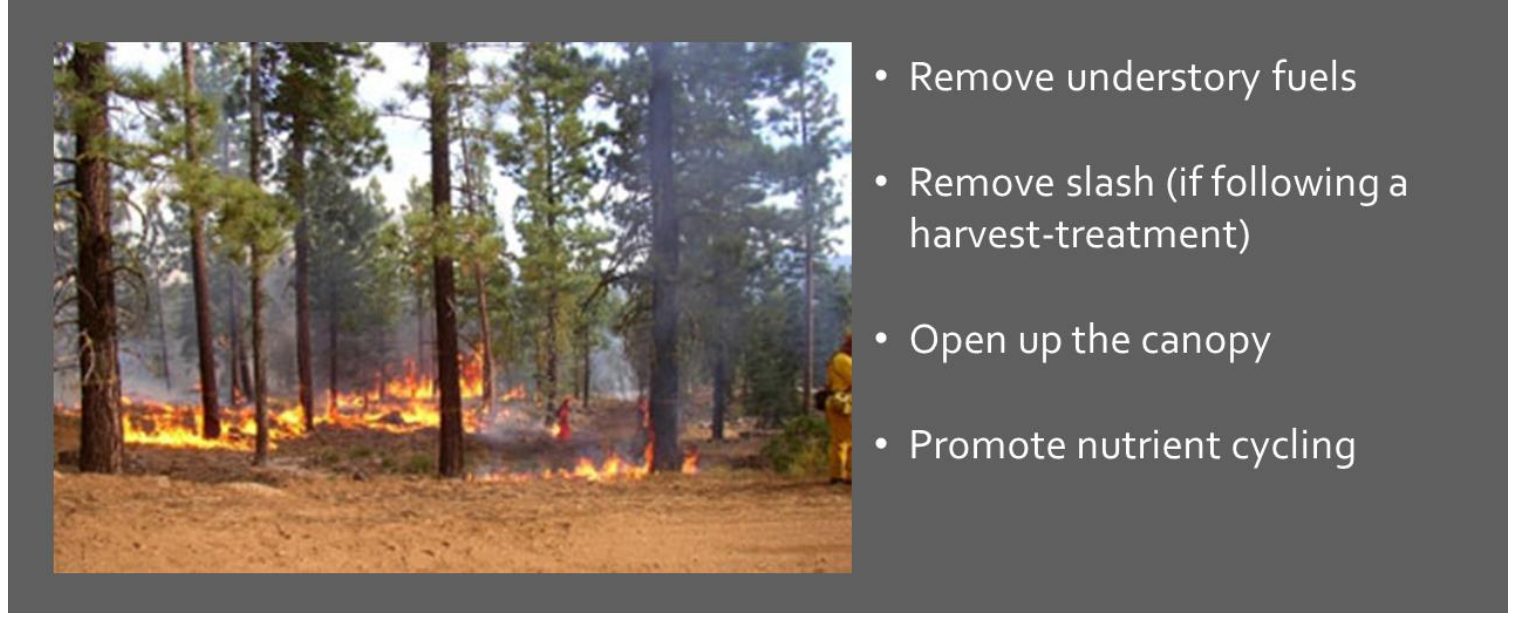




\section{C.5 Maps used in participatory mapping exercise}

These maps were printed out on large-format poster paper and hung on the walls of the focus group locations. The solid black line delineates the study area, the dark green border bounds national forest lands, and purple designates areas that are currently off limits to harvest.

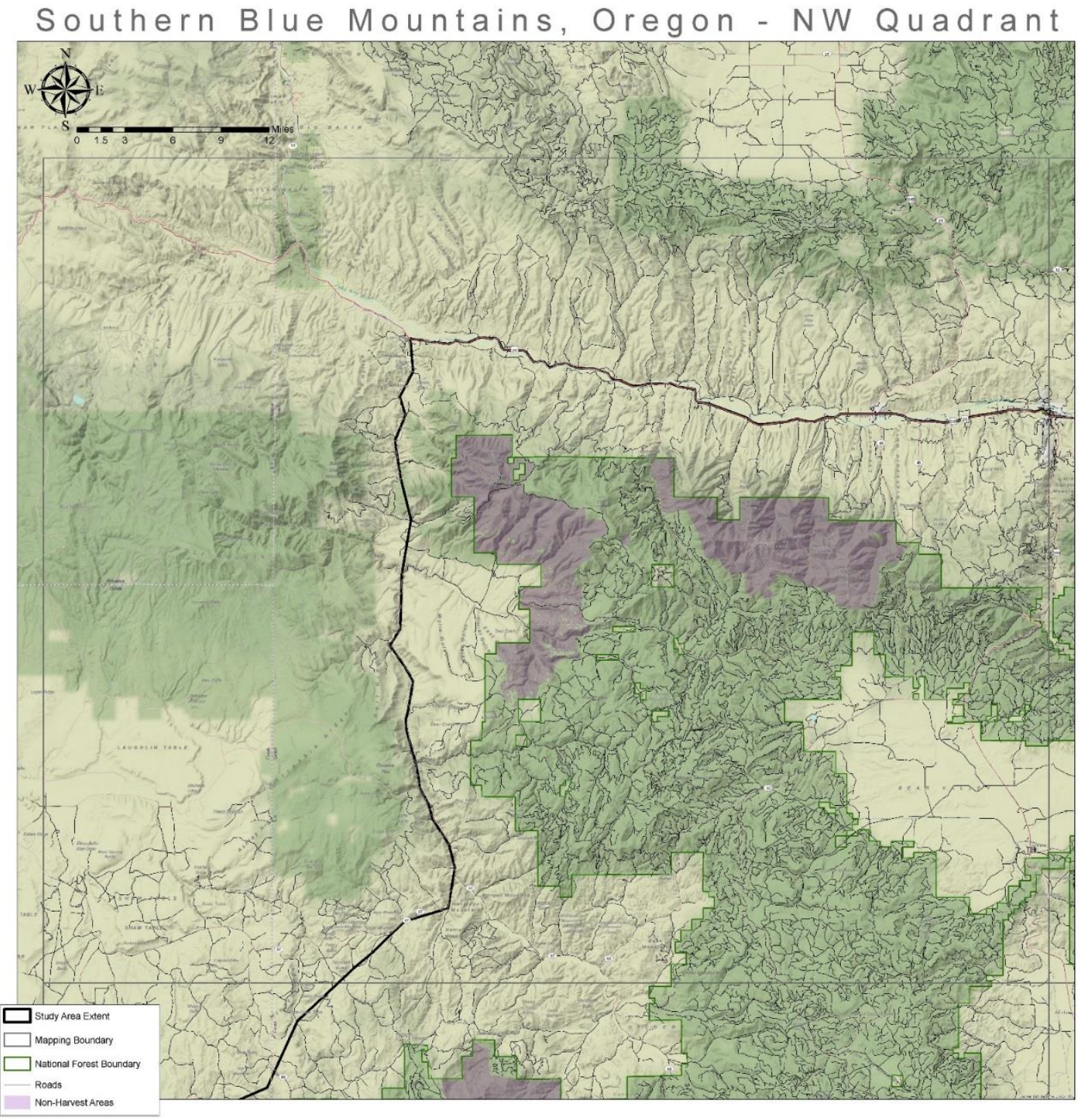


Southern Blue Mountains, Oregon - NE Quadrant

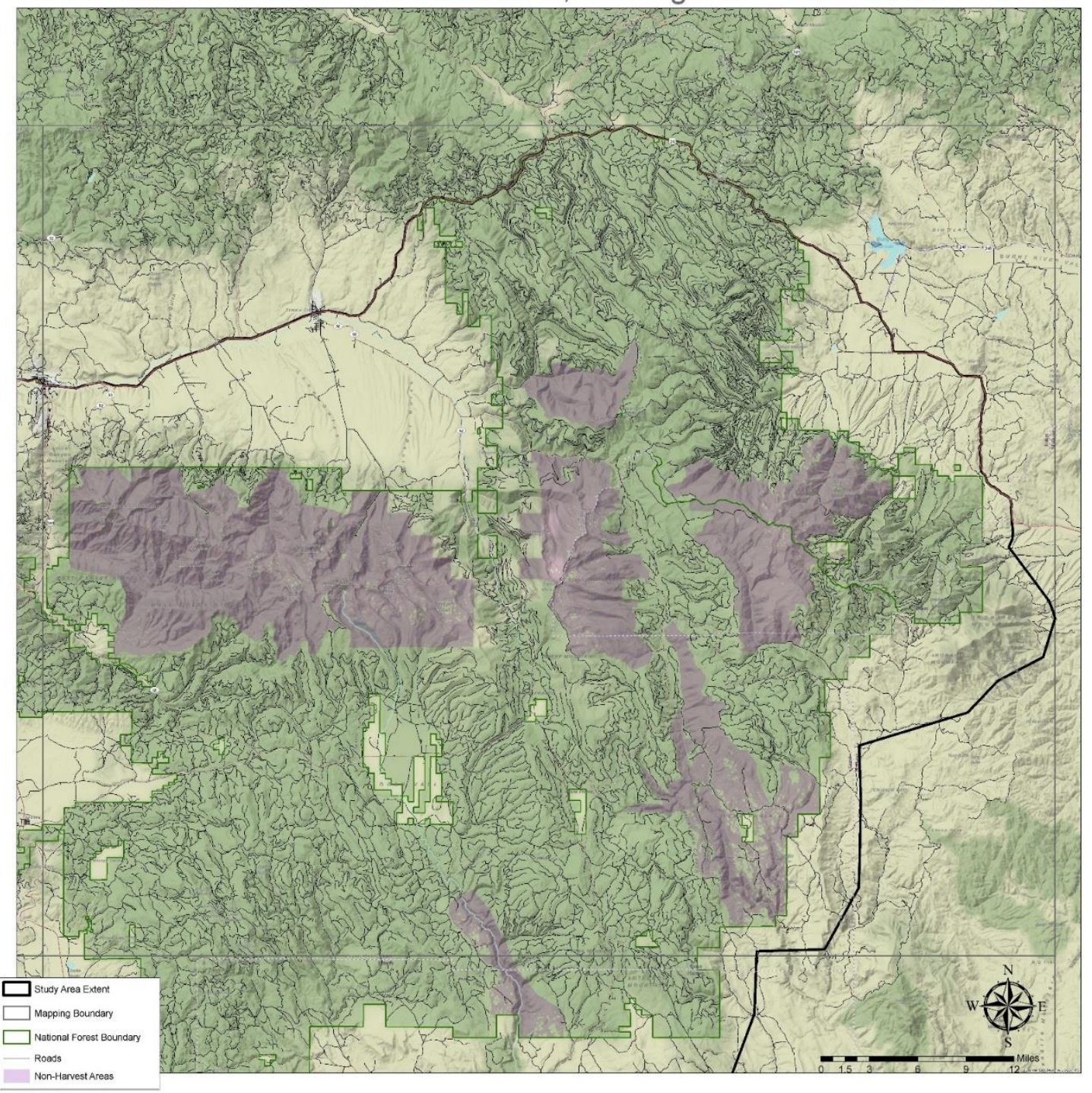




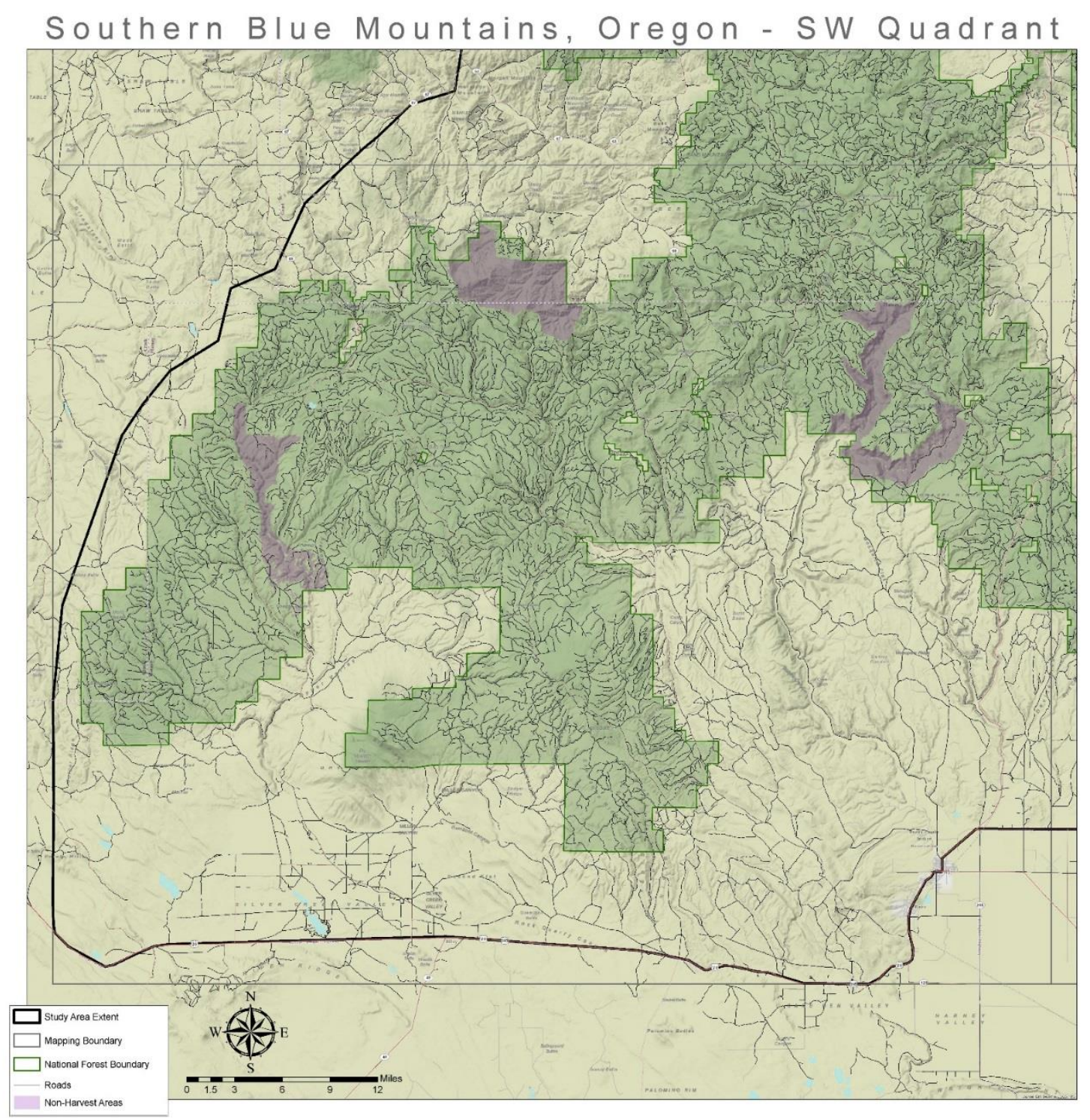


Southern Blue Mountains, Oregon - SE Quadrant

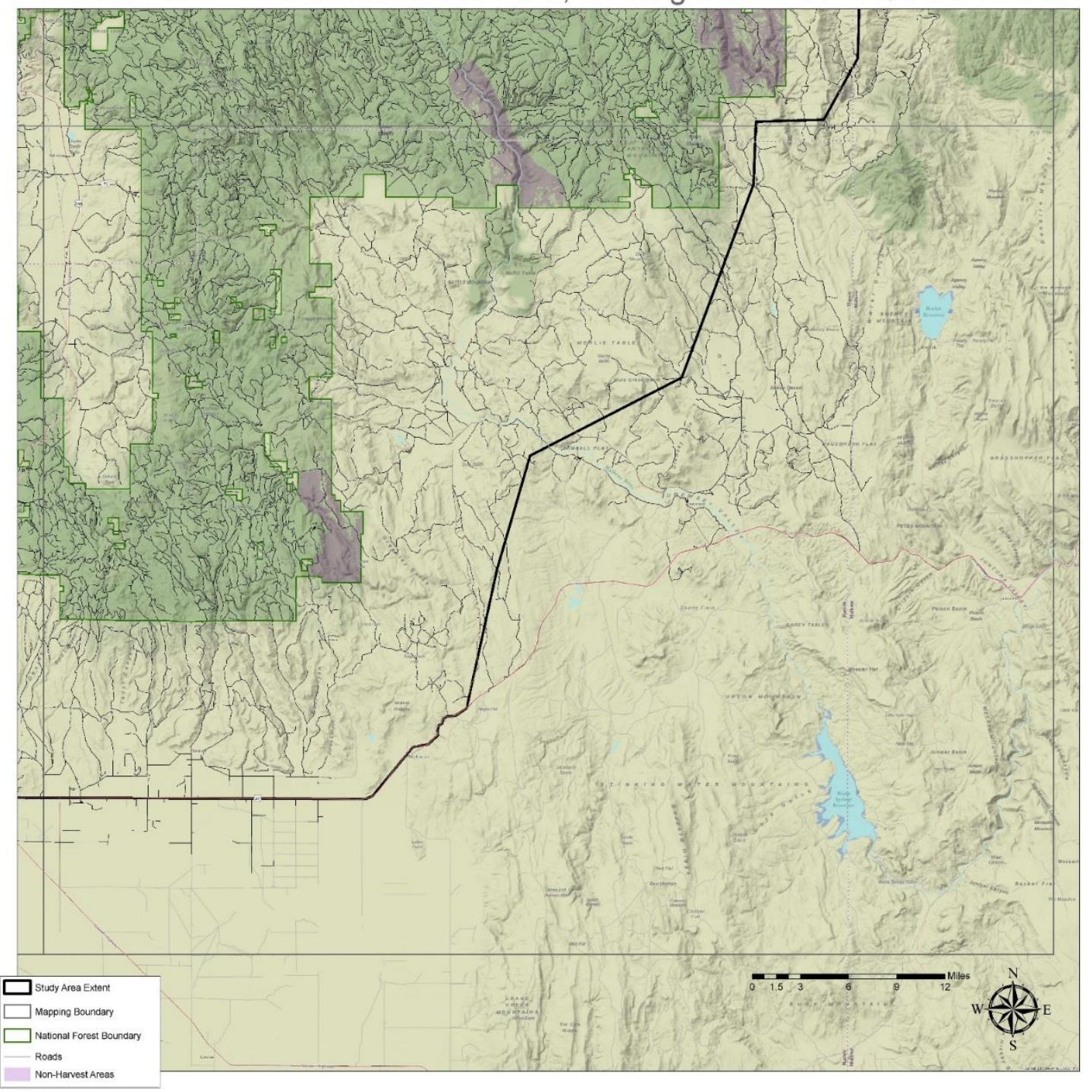




\section{C.6 Colors used in preference mapping}
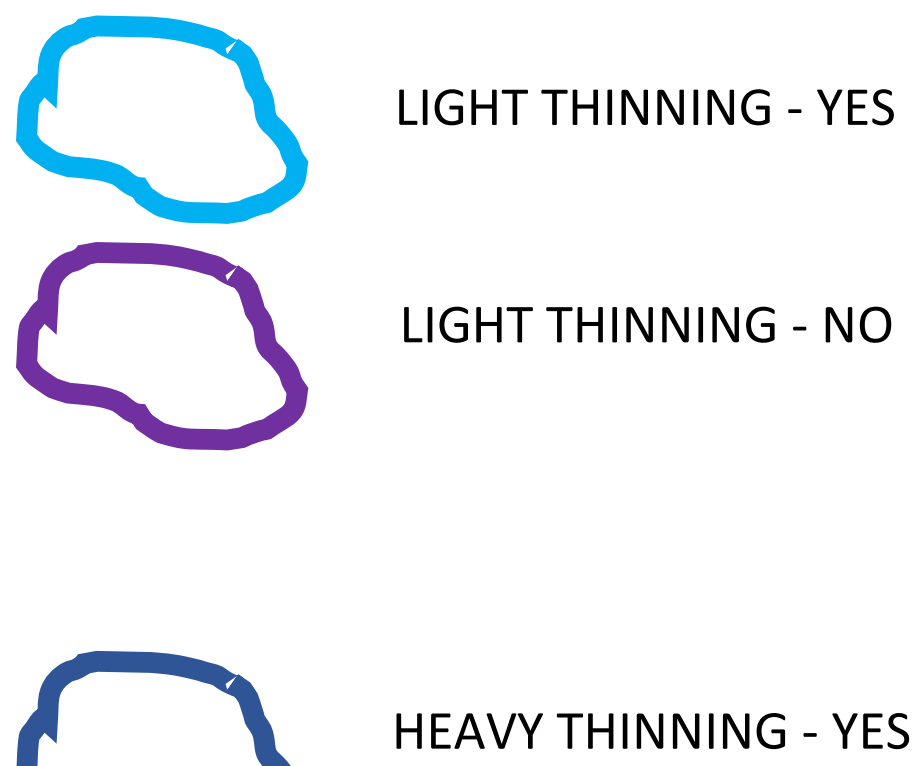

HEAVY THINNING - NO

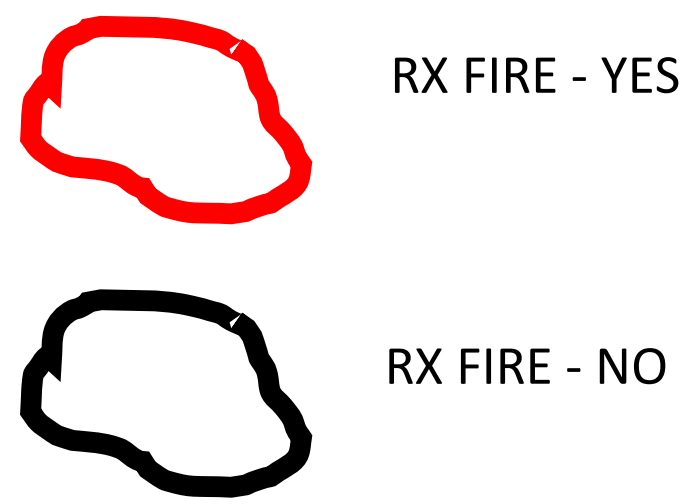

